\title{
MICROPLANKTON CHANGES THROUGH THE EARLY SILURIAN IREVIKEN EXTINCTION EVENT ON GOTLAND, SWEDEN
}

\author{
Thesis submitted for the degree of \\ Doctor of Philosophy \\ at the University of Leicester
}

by

David Neil Gelsthorpe BSc (Durham)

Department of Geology

University of Leicester

September 2002 
UMI Number: U164146

All rights reserved

\section{INFORMATION TO ALL USERS}

The quality of this reproduction is dependent upon the quality of the copy submitted.

In the unlikely event that the author did not send a complete manuscript and there are missing pages, these will be noted. Also, if material had to be removed, a note will indicate the deletion.

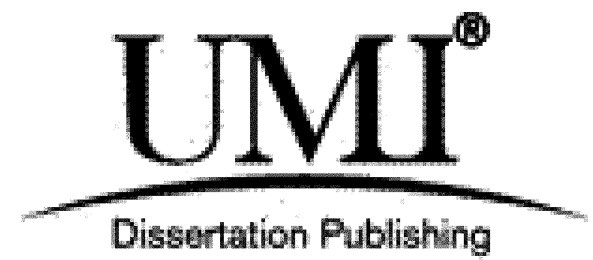

UMI U164146

Published by ProQuest LLC 2013. Copyright in the Dissertation held by the Author.

Microform Edition (c) ProQuest LLC.

All rights reserved. This work is protected against unauthorized copying under Title 17, United States Code.

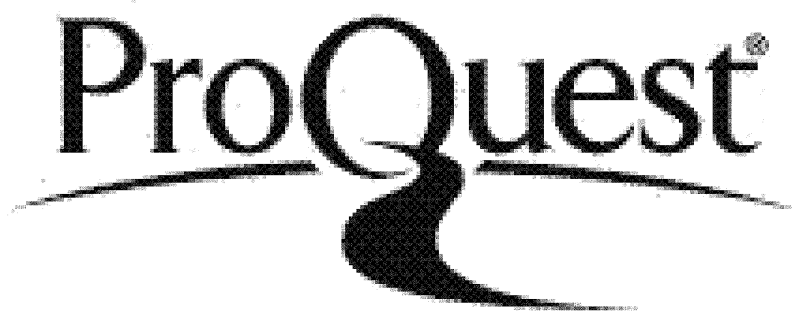

ProQuest LLC

789 East Eisenhower Parkway

P.O. Box 1346

Ann Arbor, MI 48106-1346 
"A little wobble can get worse until the whole system collapses.

But those same little wobbles are essential to a living system.

They mean the system is healthy and responsive."

John Arnold, on Jurassic Park

Jurassic Park by Michael Crichton (p247) 


\begin{abstract}
This thesis documents and analyses the extinction and origination patterns of acritarchs and prasinophyte algae at the Llandovery/Wenlock boundary in the Lower Silurian on the island of Gotland, Sweden. Closely spaced samples were collected from two sections: Lusklint 1 and Lickershamn 2, spanning the upper part of the Lower Visby Beds and almost all of the Upper Visby Beds. Errors associated with the palynological processing technique have been assessed and a new photographic technique has been developed. Five new species are described.
\end{abstract}

At least eight extinctions affecting the conodont record have been reported at this level (named the Ireviken Extinction Event (Aldridge et al. 1993, Jeppsson 1997)). The Ireviken Event has been interpreted as an example of the change from a $\mathrm{P}$ to an $\mathrm{S}$ climate state (Jeppsson 1993).

The data show a significant turnover in the phytoplankton at this time, with most of the extinctions at the end of the event $(86.3 \%$ in the top four metres of the Lusklint 1 section), after many of the conodont extinctions had already taken place. The originations are more numerous than the extinctions (54 species originate at Lusklint 1 as opposed to 44 that became extinct) and they are distributed through the whole of the Ireviken event. There is an uneven distribution across the event with more originations in the Lower Visby Beds forming a convex pattern.

The two sections analysed were compared using graphic correlation, but palynomorph range end data show considerable scatter. Peaks in the number of palynomorphs per gram of sediment suggest that the two sections completely overlap. Deposition of the thickest bentonite produced a marked drop in the number of palynomorphs per gram of sediment, but a marked rise in numbers in the following few centimetres, probably caused by a fertilization effect. $\delta^{13} \mathrm{C}$ values at Lusklint 1 remain stable in the Lower Visby Beds, but show a marked gradual rise in the Upper Visby Beds. The $\delta^{18} \mathrm{O}$ values for the same interval vary little.

The $\mathrm{P}$ and $\mathrm{S}$ model does not successfully explain all the changes recorded, but is the most comprehensive model available at this time. Additions to the model, incorporating planktonic dimethyl sulphide production and iron fertilization are presented. 


\title{
CONTENTS
}

\begin{abstract}
CONTENTS

LIST OF FIGURES

ACKNOWLEDGEMENTS Xiii
\end{abstract}

CHAPTER 1: INTRODUCTION

RESEARCH AIMS AND OBJECTIVES 1

THESIS STRUCTURE

GEOLOGICAL SETTING 2

CHRONOSTRATIGRAPHY 2

BIOSTRATIGRAPHY 5

LITHOSTRATIGRAPHY 5

PREVIOUS RESEARCH ON GOTLAND AND THE IREVIKEN EVENT 6

LOCALITIES $\quad 8$

\section{CHAPTER 2: TECHNIQUES}

SAMPLING TECHINIQUE 16

TESTING OF PALYNOLOGICAL PROCESSING TECHNIQUES: 16 INTRODUCTION

$\begin{array}{ll}\text { PROCESSING TECHNIQUE } & 18\end{array}$

TESTING THE PROCESSING TECHNIQUE $\quad 19$

RESULTS FROM REPEAT SEPARATION $\quad 20$

RESULTS FROM NITRIC ACID TESTING 23

RESULTS OF 7 $\mu \mathrm{m}$ SIEVE TEST

RESULTS FROM LYCOPODIUM SPORE NUMBERS PER GRAM OF 26 SEDIMENT TEST

RESULTS FROM THE MODERN CONTAMINANTS IN DEIONISED 26 WATER TEST 
DISCUSSION

CONCLUSIONS

LOGGING TECHNIQUE 29

PHOTOGRAPHIC TECHNIQUE 29

CHAPTER 3: THE CLASSIFICATION OF PALYNOMORPHS AND SYSTEMATIC PALAEONTOLOGY

ACRITARCH AND PRASINOPHYTE ALGAL CLASSIFICATION 31

SYSTEMATIC PALAEONTOLOGY: TERMINOLOGY 32

PLATE EXPLANATIONS 32

SYNONYMY LISTS $\quad 34$

REPOSITORY 34

ANNOTATED SPECIES LIST

Class PRASINOPHYCEAE Christensen 1962

Cymatiosphaera heloderma Cramer \& Díez, 1972b 34

Cymatiosphaera aff. ledburica Dorning, 1981

Cymatiosphaera octoplana Downie, 1959

Cymatiosphaera sp. B of Le Hérissé, 1989

Dictyotidium alveolatum (Kiryanov, 1978) Le Hérissé, 1989

Dictyotidium dictyotum (Eisenack, 1938) Eisenack, 1955

Dictyotidium faviforme Schulz, 1967

Dictyotidium perlucidum Le Hérissé, 1989

Dictyotidium stenodictyum Eisenack, 1965

Duvernaysphaera aranaides (Cramer, 1964b) Cramer \& Díez, 1972b 35

Pterospermella foveolata Dorning, 1981

Pterospermella martinii Cramer, 1966a 36

Pterospermella marysae Le Hérissé, 1989

Pterospermella saturniforme sp. nov. 36

Quadraditum fantasticum Cramer, 1964b 36

Tasmanites Newton, 1875

Group ACRITARCHA Evitt, 1963

Ammonidium microcladum (Downie, 1963) Lister, 1970

Buedingiisphaeridium? globulosum sp. nov. $\quad 36$ 
Buedingiisphaeridium? aff. globulosum sp. nov. 36

Deunffia brevifurcata Hill, 1974

Deunffia monospinosa Downie, $1960 \quad 36$

Deunffia ramusculosa Downie, 1960

Diexallophasis denticulata wolynica Kiryanov, 1978

Diexallophasis gotlandica Cramer, 1970

Diexallophasis granulatispinosa (Downie, 1963) Hill, 1974

Diexallophasis remota (Deunff, 1955) Playford, 1977

Dilatisphaera laevigata Lister, 1970

Dilatisphaera williereae (Martin, 1966) Lister, 1970

Dilatisphaera quadratica sp. nov. 37

Domasia amphora (Martin, 1969) emend. Hill, 1974

Domasia bispinosa Downie, 1960

Domasia quadrispinosa Hill, 1974

Domasia trispinosa (Downie, 1960) Hill, 1974

Eisenackidium ranaemanum Le Hérissé, $1989 \quad 38$

Elektoriskos aurora Loeblich, $1970 \quad 38$

Eupoikilofusa filifera (Downie, 1959) Dorning, 1981 emend. 38

Eupoikilofusa striatifera Cramer, 1964a

Elektoriskos longispinosum sp. nov. $\quad 38$

Gorgonisphaeridium succinum Lister, $1970 \quad 38$

Gracilisphaeridium encantador (Cramer, 1970) ex Eisenack et al., $1973 \quad 38$

Helosphaeridium citrinipeltatum (Cramer \& Díez, 1972) Dorning, 1981

Helosphaeridium clavispinulosum Lister, $1970 \quad 38$

Helosphaeridium pseudodictyum Lister, $1970 \quad 38$

Hoegklintia corallina (Eisenack, 1959) Dorning, 1981

Hoegklintia digitata (Eisenack, 1938) Dorning, 1981

Hoegklintia visbyensis (Eisenack, 1959) Dorning, 1981

Leiofusa parvitatis Loeblich, 197039

Leiofusa cf. banderillae Cramer, 1964b 39

Leiosphaeridia (Eisenack, 1958b) Downie \& Sarjeant, 1963 emend. Turner, 39 1984

Leprotolypa gordonense Cramer, $1963 \quad 39$

Micrhystridium eatonense Downie, $1959 \quad 39$ 
Micrhystridium irevikensis Le Hérissé, $1989 \quad 39$

Micrhystridium stellatum Deflandre, 1945

$\begin{array}{ll}\text { Micrhystridium sp. A } & 40\end{array}$

Moyeria uticaensis Thusu, $1973 \quad 40$

Multiplicisphaeridium arbusculum Dorning, $1981 \quad 40$

Multiplicisphaeridium cladum (Downie, 1963) Eisenack, 1969

Multiplicisphaeridium fisheri (Cramer, 1968a) Lister, $1970 \quad 40$

Multiplicisphaeridium forquiferum (Cramer \& Díez, 1972b) Eisenack et al., 40 1973

Multiplicisphaeridium forquillum (Cramer \& Díez, 1972b) Eisenack et al., 40 1973

Multiplicisphaeridium minguisi Le Hérissé, $1989 \quad 40$

Multiplicisphaeridium monki Le Hérissé, $1989 \quad 40$

Multiplicisphaeridium neaghae Cramer, 1970 ex Eisenack et al., $1973 \quad 40$

Multiplicisphaeridium osgoodense (Cramer \& Díez, 1972b) Eisenack et al., 40 1973

Multiplicisphaeridium rochesterense (Cramer \& Díez, 1972b) Eisenack et al., 1973

Multiplicisphaeridium variabile (Lister, 1970) Dorning; 1981

Multiplicisphaeridium cf. variabile (Lister, 1970) Dorning, 1981

Onondagella asymmetrica (Deunff, 1954 ex Deunff, 1961) Cramer 1966b, 41 emend. Playford, 1977

Oppilatala fermosa (Cramer, 1970) Le Hérissé, 1989

Oppilatala grahni Le Hérissé, 1989

Oppilatala insolita insolita Cramer \& Díez, 1972b 41

Oppilatala insolita compacta Le Hérissé, 1989

Oppilatala juvensis Le Hérissé, 1989

Oppilatala ramusculosa (Deflandre, 1945) Dorning, 1981

Oppilatala singularis Le Hérissé, 1989

Polygonium sp. B of Le Hérissé, 1989

Pulvinosphaeridium pulvinellum Eisenack, 1954

Salopidium fragelliforme Le Hérissé, 1989

Salopidium granuliferum (Downie, 1959) Dorning, 1981

Salopidium aff. granuliferum (Downie, 1959) Dorning, 1981 
Salopidium wenlockense (Downie, 1959) Dorning, 1981

Salopidium woolhopense Dorning, 1981

Schismatosphaeridium algerense Cramer \& Díez, 1976a 42

Schismatosphaeridium longhopense Dorning, 1981

Schizmatosphaeridium perforatum Staplin et al., 1965

Schismatosphaeridium rugulosum Dorning, 1981 emend. Mullins 2001

Tunisphaeridium parvum Deunff \& Evitt, 1968

Tunisphaeridium tentaculaferum (Martin, 1967) Cramer, 1970

Tylotopalla gaupa (Cramer, 1964b) Eisenack et al., 1973

Tylotopalla robustispinosa (Downie, 1959) Eisenack et al., 1973 emend. 43

Veryhachium checkleyense Dorning, 1981

Veryhachium pertonense Dorning, 1981

Veryhachium rhomboidium (Downie, 1959) Turner, 1984

Veryhachium trispinosum (Eisenack, 1938) Stockmans \& Willière, 1962a 43

Veryhachium wenlockium (Downie, 1959) Stockmans \& Willière, 1962b 43

Visbysphaera brevifurcata (Eisenack, 1954) Lister, 1970

Visbysphaera connexa connexa Le Hérissé, 1989

Visbysphaera connexa crispa Le Hérissé, 1989

Visbysphaera connexa hirsuta Le Hérissé, 1989

Visbysphaera erratica brevis Le Hérissé, 1989

Visbysphaera gotlandica Eisenack, 1954

Visbysphaera meson (Eisenack, 1955) Lister, 1970

Visbysphaera microspinosa (Eisenack, 1954) Lister, 1970

Visbysphaera oligofurcata Eisenack, 1954

Visbysphaera pirifera pirifera (Eisenack, 1954) Kiryanov, 1978

Visbysphaera pirifera minor Le Hérissé, 1989

Visbysphaera cf. gotlandica (Downie, 1959) Dorning, 1981

Class PRASINOPHYTA, Christensen, $1962 \quad 45$

Genus Pterospermella Eisenack, $1972 \quad 45$

Pterospermella saturniforme sp. nov. $\quad 45$

Group ACRITARCHA Evitt, $1963 \quad 46$

Genus Buedingiisphaeridium Schaarschmidt, 1963 emend. Lister 197046 emend. Sarjeant \& Stancliffe 1994

Buedingiisphaeridium? globulosum sp. nov. 
Genus Dilatisphaera Lister, $1970 \quad 48$

Dilatisphaera quadratica sp. nov. $\quad 48$

Genus Elektoriskos Loeblich, $1970 \quad 49$

Elektoriskos longispinosa sp. nov. $\quad 49$

Genus Micrhystridium Deflandre, 1937, emend. Sarjeant \& Stancliffe, $1994 \quad 47$

Micrhystridium sp. A $\quad 51$

\section{CHAPTER 4: RESULTS}

EXTINCTION, ORIGINATION AND ABUNDANCE DATA 54

Palynomorph extinction and origination data $\quad 54$

Palynomorph extinctions $\quad 54$

Palynomorph originations $\quad 56$

Range end confidence limits $\quad 56$

$\begin{array}{ll}\text { The fraction below } 7 \mu \mathrm{m} \text { in size } & 61\end{array}$

$\begin{array}{ll}\text { The conodont extinction pattern } & 61\end{array}$

The palynomorph abundance data $\quad 61$

General trends seen at Lusklint 1

General trends seen at Lickershamn 2

Multivariate analysis $\quad 64$

COMPARISON TO OTHER PALYNOLOGICAL STUDIES OUTSIDE OF 71

GOTLAND

GRAPHIC CORRELATION

THE EFFECT OF BENTONITE DEPOSITION ON THE 79

PALYNOMORPH RECORD

THE GEOCHEMICAL RECORD $\quad 81$

Stable carbon and oxygen isotope data for Lusklint 1

\section{CHAPTER 5: DISCUSSION AND CONCLUSION}

PALYNOMORPH EXTINCTIONS, ORIGINATIONS, ABUNDANCE 
$\begin{array}{ll}\text { Extinctions and originations } & 83\end{array}$

Range end confidence limits $\quad 84$

$\begin{array}{ll}\text { Multivariate analysis } & 84\end{array}$

Comparison to other palynological studies $\quad 85$

THE RESPONSE OF THE PALYNOMORPHS TO THE DEPOSITION OF 86 THE UPPER BENTONITE

$\begin{array}{ll}\text { GRAPHIC CORRELATION } & 88\end{array}$

THE GEOCHEMICAL RECORD $\quad 88$

Stable carbon and oxygen isotope data from Lusklint 1

MODELS FOR THE PALAEOZOIC 92

Extinction mechanisms

Sea level change $\quad 95$

$\begin{array}{ll}P \text { and } S \text { cyclicity } & 98\end{array}$

FUTURE RESEARCH 107 


\section{List of Figures}

Text-fig

Description

Page

1.1 Map showing the outcrop pattern of the Visby Beds and the 3 Högklint Formation in Gotland.

1.2 Chronostratigraphy and lithostratigraphy of Gotland. 4

1.3 Palaeogeography of the Baltic region during the period of 7 deposition of the Högklint Formation.

1.4 Sketch map showing the locations of Lusklint 1 and Lickershamn 9

2.

1.5 Stratigraphic log of the lower part of the Lusklint 1 section. 10

1.6 Stratigraphic log of the upper part of the Lusklint 1 section. 11

1.7 Photograph showing the stratigraphy 150m north of Lusklint 1 . 12

$1.8 \quad$ Stratigraphic log of the Lickershamn 2 section. 14

$1.9 \quad$ Photograph showing the stratigraphy at Lickershamn $2 . \quad 15$

2.1 Graph showing the number of palynomorphs per gram of sediment 21

recorded in each separation procedure when carried out 1-6 times, sample DG00LK1.258.

2.2 Percentage abundance of each arcitarch subgroup recorded in each of the six separations. Sample DG00LK1.258

2.3 Percentage abundance of each arcitarch genus recorded in each of the six separations, sample DG00LK1.258.

2.4 Percentage abundance of each acritarch subgroup recorded in sample DG00LK1.257 when the sample was treated with nitric acid and when nitric acid was not used during processing.

3.1 Examples of the measurements referred to in Chapter 3.

3.2 Diagram showing the grid reference code used in locating palynomorphs under the SEM.

3.3 Illustration of the variation within the newly defined acritarch species.

4.1 Stratigraphic range diagram plotted for Lusklint 1, showing the 
species that show last appearances in the section and probable Lazarus taxa.

4.2 Stratigraphic range diagram plotted for Lickershamn 2 showing a. the species that show last appearances in the section and probable Lazarus taxa; b. the species that show first appearances in the section.

4.3 Stratigraphic range diagram plotted for Lusklint 1, showing the species that show first appearances in the section and probable Lazarus taxa.

4.4 Graph showing a species that occurs in every sample within its range, but has a gradual decline in numbers.

4.5 Graph showing a species that does not occur in every sample within its range, but is abundant in most of the section and has a sudden decline in numbers

4.6 Table showing the calculated distance the range ends of the species at Lickershamn 2 should be extended, according to point estimates of the true stratigraphic range ends

4.7 Stratigraphic range diagram for the conodonts through the Ireviken Event.

4.8 Plots showing the three-dimensional distribution of the samples at Lusklint 1 after correspondence analysis.

4.9 Cluster analysis dendrogram for samples from Lusklint 1.

4.10 Table showing the cluster analysis groups identified on text-fig.

4.6 relative to the Lusklint 1 samples in stratigraphic order.

4.11 Plots showing the three-dimensional distribution of the species at Lusklint 1 after correspondence analysis.

4.12 Cluster analysis dendrogram for species from Lusklint 1.

4.13 Plots showing the three-dimensional distribution of the samples at

Lickershamn 2 after correspondence analysis.

4.14 Cluster analysis dendrogram for samples from Lickershamn 2 . 70

4.15 Table showing the cluster analysis groups identified on text-fig. 70 4.14 relative to the Lickershamn 2 samples in stratigraphic order.

4.16 Plots showing the three-dimensional distribution of the species at 72 Lickershamn 2 after correspondence analysis. 
4.17 Cluster analysis dendrogram for species from Lickershamn $2 . \quad 73$

4.18 Graph showing all the first and last palyniomorph appearance 75 points common to both Lusklint 1 and Lickershamn 2.

4.19 Graph showing the reliable first and last palynomorph appearance 75 points common to both Lusklint 1 and Lickershamn 2.

4.20 Graph showing the number of palynomorphs per gram of sediment 78 at Lickershamn 2 superimposed onto the number of palynomorphs per gram of sediment at Lusklint 1.

4.21 Graph showing the reliable first and last palynomorph appearance points, conodont first and last appearance points and number of palynomorphs per gram of sediment peaks common to both sections.

4.22 Graph showing the absolute abundance and percent abundance of selected species across the upper bentonite.

4.23 Graph showing the $\delta^{13} \mathrm{C}$ whole rock analysis relative to the base of the section sampled for this study, data provided by Corfield and Siveter.

4.24 Graph showing the $\delta^{18} \mathrm{O}$ whole rock analysis relative to the base of 82 the section sampled for this study, data provided by Corfield and Siveter.

5.1 Summary of the apparent migrations between Gotland and the Welsh Basin at the Llandovery/Wenlock boundary.

5.2 Cartoon showing the relative levels of $\delta^{12} \mathrm{C}$ incorporation into

Silurian sediment, according to the $\mathrm{P}$ and $\mathrm{S}$ model of Jeppsson (1990).

5.3 Cartoon showing the relative levels of $\delta^{16} \mathrm{O}$ incorporation into

Silurian sediment, according to the $\mathrm{P}$ and $\mathrm{S}$ model of Jeppsson (1990).

5.4 Diagram showing the commonly used sea level curves for the 96 lower Silurian.

5.5 Cartoon showing the characteristics of the late Llandovery P-state 100 and the early Wenlock S-state (after Jeppsson 1990).

5.6 Cartoon showing the characteristics of the transition between the 100 late Llandovery P-state and the early Wenlock S-state (after 
Jeppsson 1990).

5.7 Cartoon showing the relationship between DMS production in 102 plankton and increased cloud cover.

5.8 False-colour image from the Coastal Zone Colour scanner on the 104 Nimbus 7 satellite, October 1983. This image indicates the chlorophyll-rich plume extending west from the Galapagos Islands after iron seeding.

5.9 Satellite image showing a massive sandstorm blowing off northwestern Africa.

5.10 Map showing the large extent of the planet affected by deposition 106 of wind blown dust. 


\section{ACKNOWLEDGEMENTS}

First and foremost, I would like to acknowledge the help and support of Dick Aldridge. It was Dick who devised this project and he has proved to be an excellent supervisor. His knowledge of the Silurian is difficult to surpass and he has always found time for me even when he is snowed under with his duties as head of department. His efforts in the field were very much appreciated. The other person without whom this project would not have been possible is Lennart Jeppsson. His help and enthusiasm in the field were invaluable. We would have really struggled in Gotland if he had not given up much of his field season to drive us about, show us localities and arrange all the accommodation details.

The other major contributors were Stewart Molyneux, Ken Dorning, Gary Mullins and Alain Le Hérissé. Stewart was fantastic help particularly in the early days of my project. My total lack of any palynology experience meant that to begin with there was a steep learning curve, which Stewart guided me along with lots of encouragement. The insatiable enthusiasm and the breadth of acritarch knowledge of Ken has been a big help throughout the project. My regular trips up to Sheffield have always been very useful and I have always been impressed by how much time he has set aside to discuss things with me. Gary is probably the unsung hero of my project. He has been so useful to have around to get quick answers on those little questions even if occasionally his response is "I've never seen any acritarchs like that before either". The number of times I've been round his office to check details of obscure papers, I think he might be as pleased as I am that I've finished! It was really fantastic to get help from Alain in the early days of my project. His vast knowledge of Gotland acritarchs was one of the things that really helped me on the right track when the task ahead seemed a little overwhelming.

I would also like to thank Derek Siveter and Richard Corfield for kindly letting me use their stable isotope data, David Loydell for detailed discussions on the Silurian sea level curves, Rex Harland for discussions with him on dinoflagellates, Andrew Swift for his technical help and Rod Branson for his help on the SEM. Sarah Gabbott has always been there for a chat when things were not going quite to plan.

I owe a huge thanks to my friends in Leicester. Thanks to my housemates Rachel and Simon for putting up with me writing up. Thanks to my office mates (Hannah, Matt, Andrew and Pat) for regular distractions especially on a Friday evening. Thanks especially to Pat who has taken the brunt of things and always been loads of fun. A special mention must be made for 
the circuits team: Pat, Heike, Rich, and Gav who gave me a good excuse not to work on a Tuesday evening and have a laugh. Thanks to the other distracters: Dave, James T., James H., George, Mark Moocow, Annabel, Natalie, Craig B. and Craig C.. I'd also like to thank my Durham friends especially Bec, who are always there to remind me how much fun we had when we were undergrads and occasionally bring me back down to earth.

Finally, I am indebted to my family. To my Mum and Dad who have always been there to support and encourage me and to my brothers Andy and Mark who are always good fun. 


\title{
INTRODUCTION
}

\section{RESEARCH AIMS AND OBJECTIVES}

\begin{abstract}
Aims
THE aims of this study are to increase knowledge of the palynomorph changes over the Ireviken Event, expand our understanding of the environmental changes that occurred at this time and to test causative models.
\end{abstract}

\section{Objectives}

1). To collect high-density samples from the island of Gotland, Sweden across the Ireviken Event, which spans the Llandovery-Wenlock boundary. To process these samples for the recovery of palynomorphs and to document the ranges of microfossil taxa through the Event.

2). To compare the palynomorph record statistically to that of the conodonts through the Ireviken Event.

3). To compare the palynomorph record to that of stable carbon isotope $\left(\sigma{ }^{13} \mathrm{C}\right)$ and stable oxygen $\left(\sigma{ }^{18} \mathrm{O}\right)$ records.

4). To test the P \& S ocean/atmosphere model of Jeppsson (1990) in explaining palaeoenvironmental change.

\section{THESIS STRUCTURE}

\section{Chapter 1.}

Introduction. This chapter, written in the style of the journal Palaeontology, includes general information on the geology of Gotland, a brief history of research, the stratigraphy and list of localities.

\section{Chapter 2.}

Techniques. This chapter begins with a description of the sampling technique, goes on to describe in detail the processing technique used and outlines previous research. The adequacy of different processing and logging techniques is assessed and a modified processing technique is discussed. The logging and the photographic techniques are described. This 
chapter is written in the style of the Journal of Micropalaeontology, where much of a preliminary version has already been published (Gelsthorpe 2002).

\section{Chapter 3.}

The classification of palynomorphs and systematic palaeontology. A brief résumé of important and recent developments in palynomorph classification is presented. An annotated list of prasinophyte algae and acritarchs recovered is provided and the systematic palaeontology of selected taxa is presented. This chapter is written in the style of the journal Palaeontology.

\section{Chapter 4.}

Results. This chapter, written in the style of the journal Palaeontology, reviews the available palynomorph, conodont and stable carbon and oxygen isotope record data for the Ireviken Event.

\section{Chapter 5.}

Discussion and conclusion. This chapter, written in the style of the journal Palaeontology, reviews the implications of the palynomorph record found on Gotland. The possible explanations of the patterns seen are discussed and more plausible scenarios are analysed in greater detail. A modified P and S model is presented. The focus of future studies is outlined.

\section{GEOLOGICAL SETTING}

The Lower Silurian rocks of Gotland form an extensive outcrop on the island, with the Lower and Upper Visby beds and the Högklint Formation (the Llandovery/Wenlock boundary beds) in the north-west (Text-fig. 1.1). All the beds/formations dip at around $3^{\circ}$ to the southeast.

\section{CHRONOSTRATIGRAPHY}

The Llandovery and Wenlock series are the first and second series of the Silurian System (Text-fig. 1.2). The standard Silurian series are comprehensively reviewed in Holland and Bassett (1989). A K-Ar biotite sample from Ireviken 3 in Gotland has given an estimated age of $430.5 \pm 6 \mathrm{Ma}$ for the Llandovery/Wenlock boundary (Dorning and Harvey 1999). 


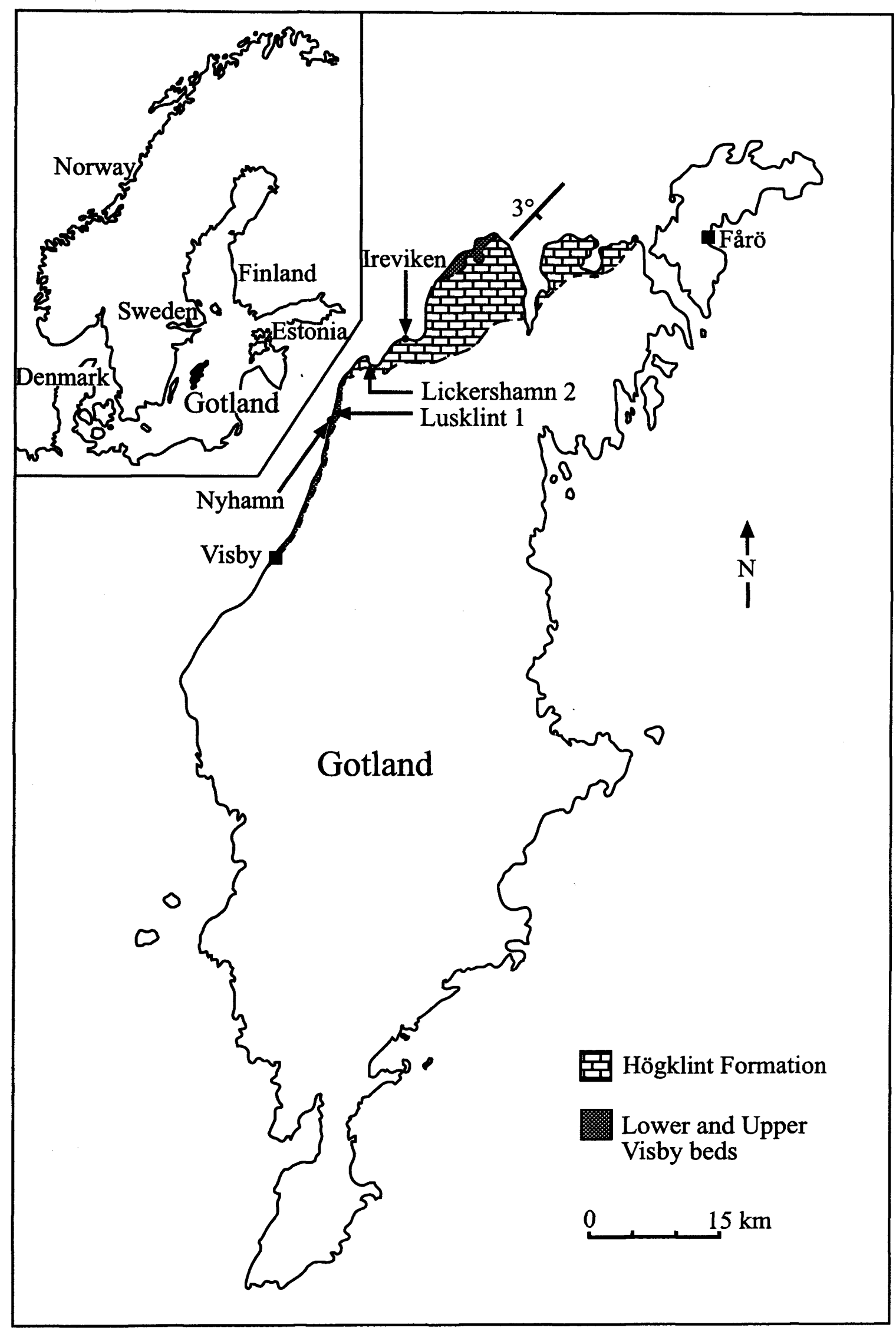

TEXT-FIG. 1.1 The outcrop of the Visby Beds and the Högklint Formation in Gotland (after Lé Hérissé 1989) 


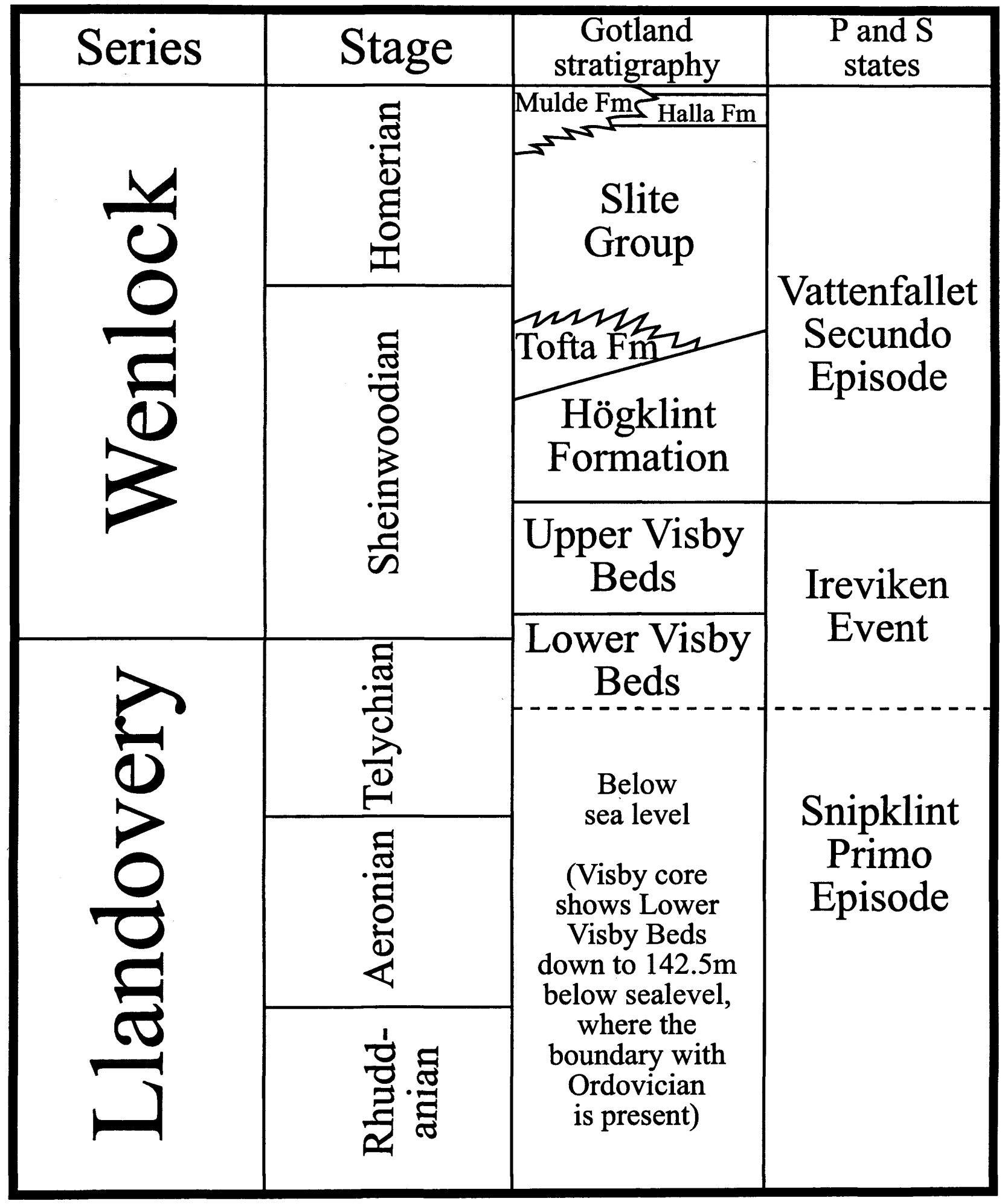

TEXT-FIG. 1.2 Chronostratigraphy and lithostratigraphy stratigraphy of Gotland, after Holland and Bassett (1989). Oceanic P and S states after Jeppsson (1990, 1993, 1997). Formation and time intervals not to scale. 


\section{BIOSTRATIGRAPHY}

The Lower and Upper Visby beds have generally been considered to be late Llandovery to early Wenlock in age (Jaanusson et al. 1979), but the precise level of the Llandovery/Wenlock boundary in Gotland has never been directly correlated with the stratotype at Hughley Brook, Shropshire, England. The most accurate biostratigraphical correlation to date has been made by Jeppsson and Männik (1993) who, correlating with the Estonian Viki core and then to Gotland, placed the base of the Wenlock somewhere below conodont Datum 2 which is defined by the extinction of the conodont Ozarkodina polinclinata. Loydell et al. (1998) attempted a similar correlation using the Estonian Ohesaare core, but the conodont to graptolite correlation in the Llandovery/Wenlock boundary beds was recorded as being uncertain.

\section{LITHOSTRATIGRAPHY}

A description of the lithologies of the late Llandovery and early Wenlock beds of Gotland is given below (after Hede 1960, Laufeld 1974).

The Lower Visby Beds are dominated by soft, blue-grey marls with common light greenishgrey limestone nodules. The nodules become more numerous upwards and increasingly coalesce into limestone bands, as the Lower Visby beds pass into the Upper Visby Beds. Three prominent bentonites are identified, with the largest (the upper bentonite, the base of which is used as a reference level) $55 \mathrm{~mm}$ thick.

The change from the Lower to Upper Visby Beds is marked by the appearance of a dense layer of Phaulactis solitary corals at the base of the Upper Visby Beds. Upwards through the section, light grey bioclastic limestone becomes the dominant lithology in near continuous beds. An inconspicuous clay layer (a few millimetres thick), $1.9 \mathrm{~m}$ below the base of the Högklint Formation, is used as a reference level.

The rapid transition into the massive bioclastic limestones of the Högklint Formation is marked by the first appearance of a light pink crinoid limestone; these beds are punctuated by occasional patch reefs (up to $35 \mathrm{~m}$ thick Riding 1981), which severely compress the beds below. Along the outcrop there is little variation in overall lithology within the Lower and Upper Visby beds. 
The geology of the north-west of Gotland is covered by the 1:50 000 Aa 183 Visby and Lummelunda sheet, 1940.

\section{PREVIOUS RESEARCH ON GOTLAND AND THE IREVIKEN EVENT}

\section{Stratigraphy}

The first modern, comprehensive study of the stratigraphy of Gotland was completed by Hede (1960). After extensive restudy of the Lower and Upper Visby beds and the Högklint Formation, Manten (1971) expanded on Hede's work. The main features of Gotland geology were again reviewed in Laufeld and Bassett (1981), who suggested a pulsatory regression through the Silurian on a palaeoshoreline some distance to the north of Gotland. A palaeogeographic map for the early Wenlock (Text-fig. 1.3) was produced. Bassett et al. (1989) reviewed the tectonics, palaeogeography, palaeontology and stratigraphy of the region and correlated the strata with the type sections and other regions. A study of the development of Högklint Formation patch reefs was published in great detail by Watts and Riding (2000). The plate tectonics and structural geology of Baltica during the Palaeozoic was reviewed by Torsvik et al. (1990), who presented a plate reconstruction for the early Wenlock.

\section{Palaeontology}

The pioneering work of Hede (1960) on the stratigraphy and palaeontology of Gotland provided a glimpse of the richness of the fossil record on the island.

The micropalaeontology of Gotland has been analysed by a number of authors. Significant publications include: Laufeld (1974) on chitinozoans, Martinsson $(1962,1967)$ on ostracods and numerous publications by Jeppsson (e.g. 1993, 1998) on conodonts. A study of the acritarchs through the entire Silurian succession of Gotland was published by Le Hérissé (1989), with species descriptions and ranges from the (Llandovery age) Lower Visby beds to the (Ludlow age) Sundre Formation. Le Hérissé showed that there are many originations and extinctions through the Lower and Upper Visby beds and the lowermost Högklint Formation, though he only presented the acritarch occurrences from five samples at this level.

The first major study into the late Llandovery and early Wenlock was based on the Vattenfallet section, just outside Visby, around 20km south of Lusklint 1 (Jannusson et al. 1979). A team of 32 specialists analysed the occurrences of various fossil groups: The authors 


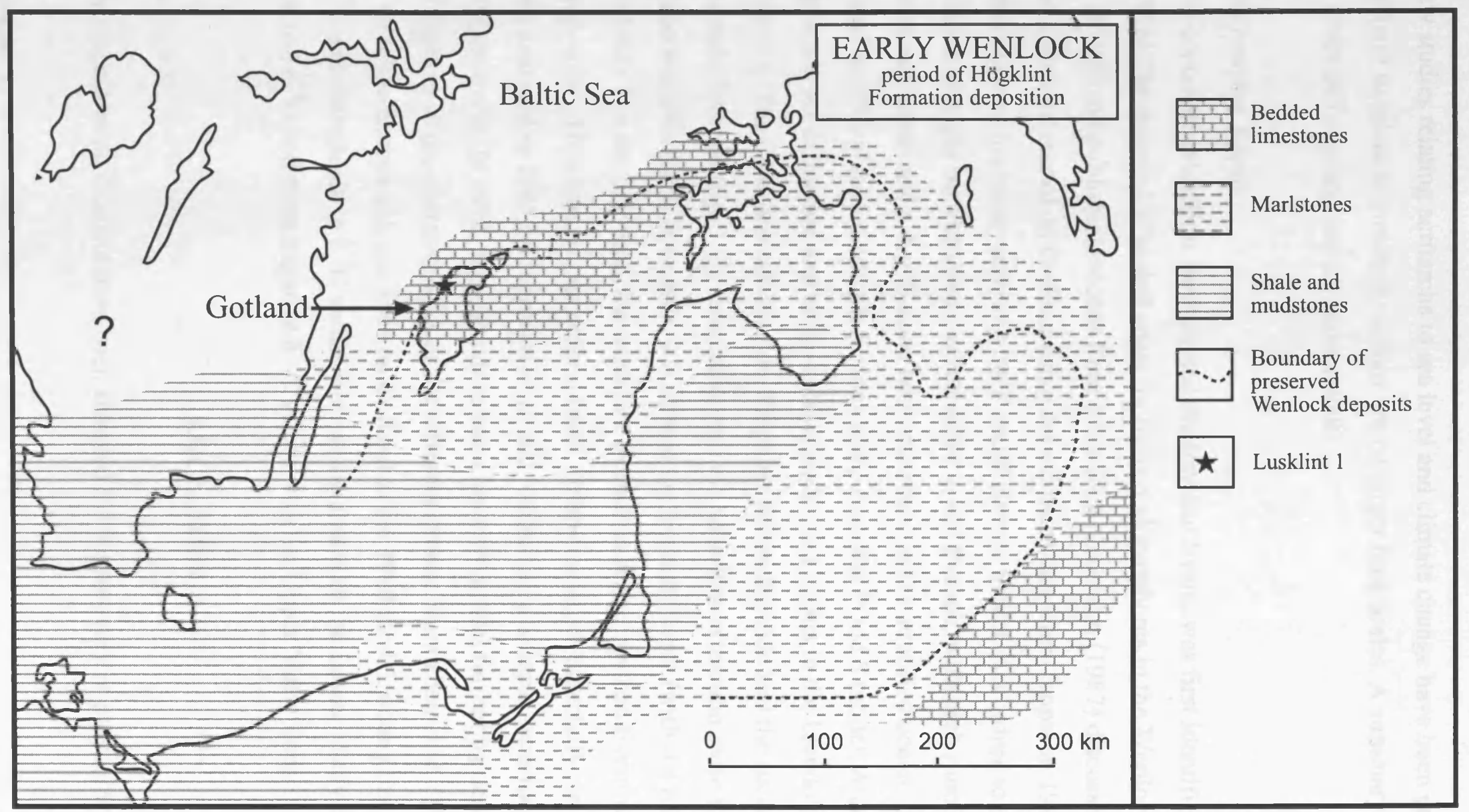

TEXT-FIG. 1.3. Palaeogeography of the Baltic during the period of deposition of the Högklint Formation during the early Wenlock (after Laufeld and Bassett 1981). 
included Cramer et al. (1979), who produced a range table of acritarchs through the Upper Visby Beds and the Högklint Formation.

Few studies relating acritarchs to sea level and climate change have been published. They are difficult to relate to this study as they are on larger time scales. A summary of recent studies is given in Tongiorgi and Di Milia (1999).

\section{The Ireviken Event}

The conodont extinction, now termed the Ireviken Event, was first identified by Aldridge (1976). He recorded a 'global crisis for the conodontophores in the Wenlock' from collections in Britain and published records from other areas. Jeppsson (1987) discussed the lithological and conodont record on Gotland using the evidence that later (Jeppsson 1990) formed the foundation of his paper outlining the $\mathrm{P}$ and $\mathrm{S}$ climate model. According to the model, the Silurian changes between two climate states: a wet P-state, with high runoff and a well circulated ocean and a dry S-state, with low runoff and a stratified ocean. Using the global faunal and floral record and predictions made from the P and S model, Aldridge et al. (1993) identified six extinction and origination episodes and events in the Llandovery and earliest Wenlock. The transition between the Snipklint Primo Episode and the succeeding Vattenfallet Secundo Episode (fig. 1.2), associated with the conodont extinction close to the Llandovery/Wenlock boundary, was named the Ireviken Event (with the reference section on Gotland). For the first time, the conodont extinction at the Ireviken Event was described as 'step-wise'. The changes that several fossil groups undergo (especially the conodonts) were then analysed in 1995 by Jeppsson et al. and 'community collapse' was identified at the Ireviken event. In 1998, Jeppsson developed his 1990 model further by describing the differences in the characteristics of the different events. Samtleben et al. (1996) were the first to tie in the isotope changes seen on Gotland to the 1990 model, noting that more negative $\delta^{18} \mathrm{O}$ and more positive $\delta^{13} \mathrm{C}$ values were associated with the Lower Visby Beds and more positive $\delta^{18} \mathrm{O}$ and more negative $\delta^{13} \mathrm{C}$ values with the Upper Visby Beds.

\section{LOCALITIES}

Two localities on Gotland have been sampled for the recovery of palynomorphs:

\section{Lusklint 1.}

(CK 4675 0680); Text-figs. 1.1., 1.4., 1.5, 1.6., 1.7. A cliff section $2.08 \mathrm{~km}$ west-north-west of Lummelunda church. From the northwestern corner of the large raised beach quarry above 


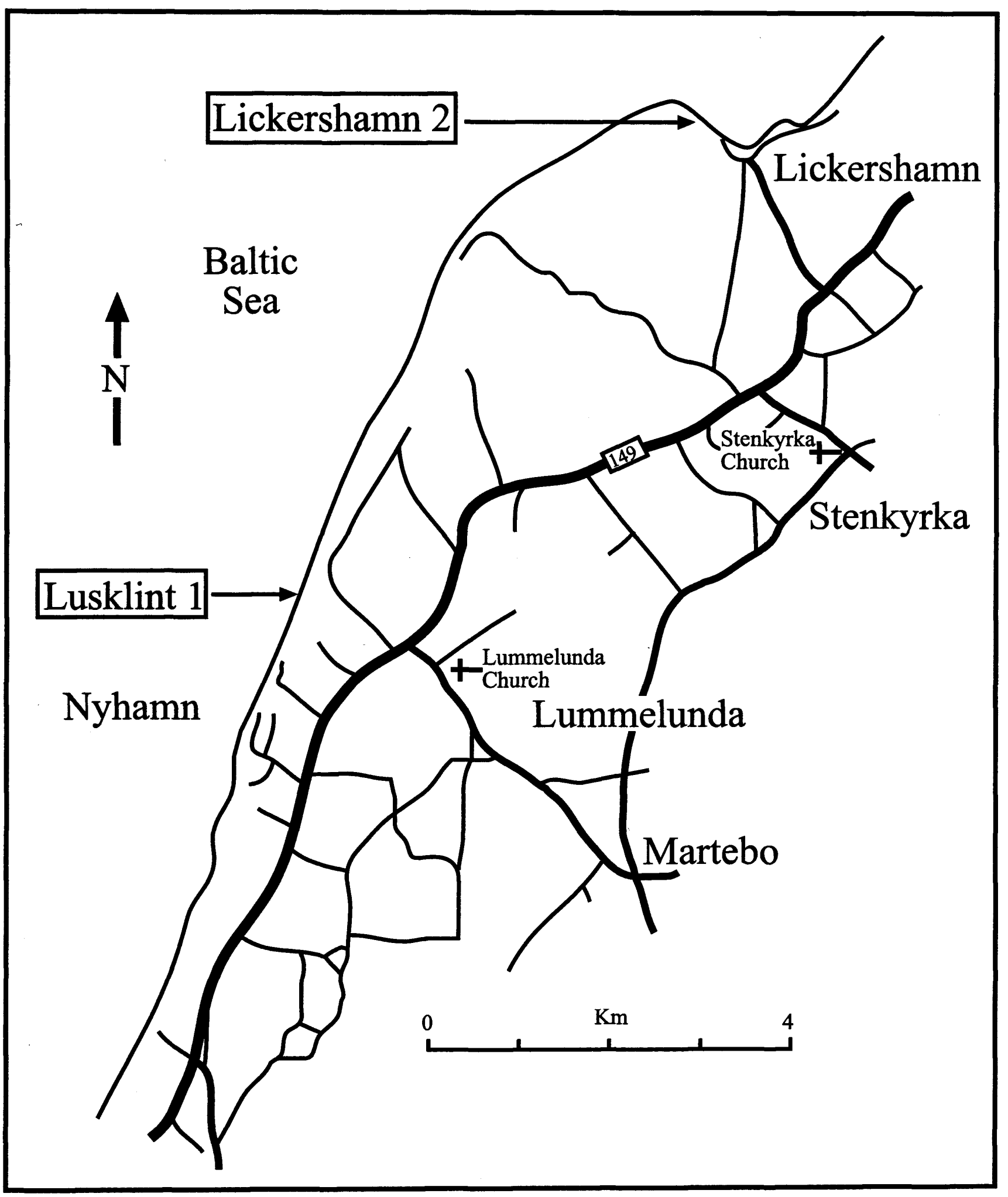

TEXT-FIG. 1.4. Sketch map showing the location of Lusklint 1 and Lickershamn 2. 


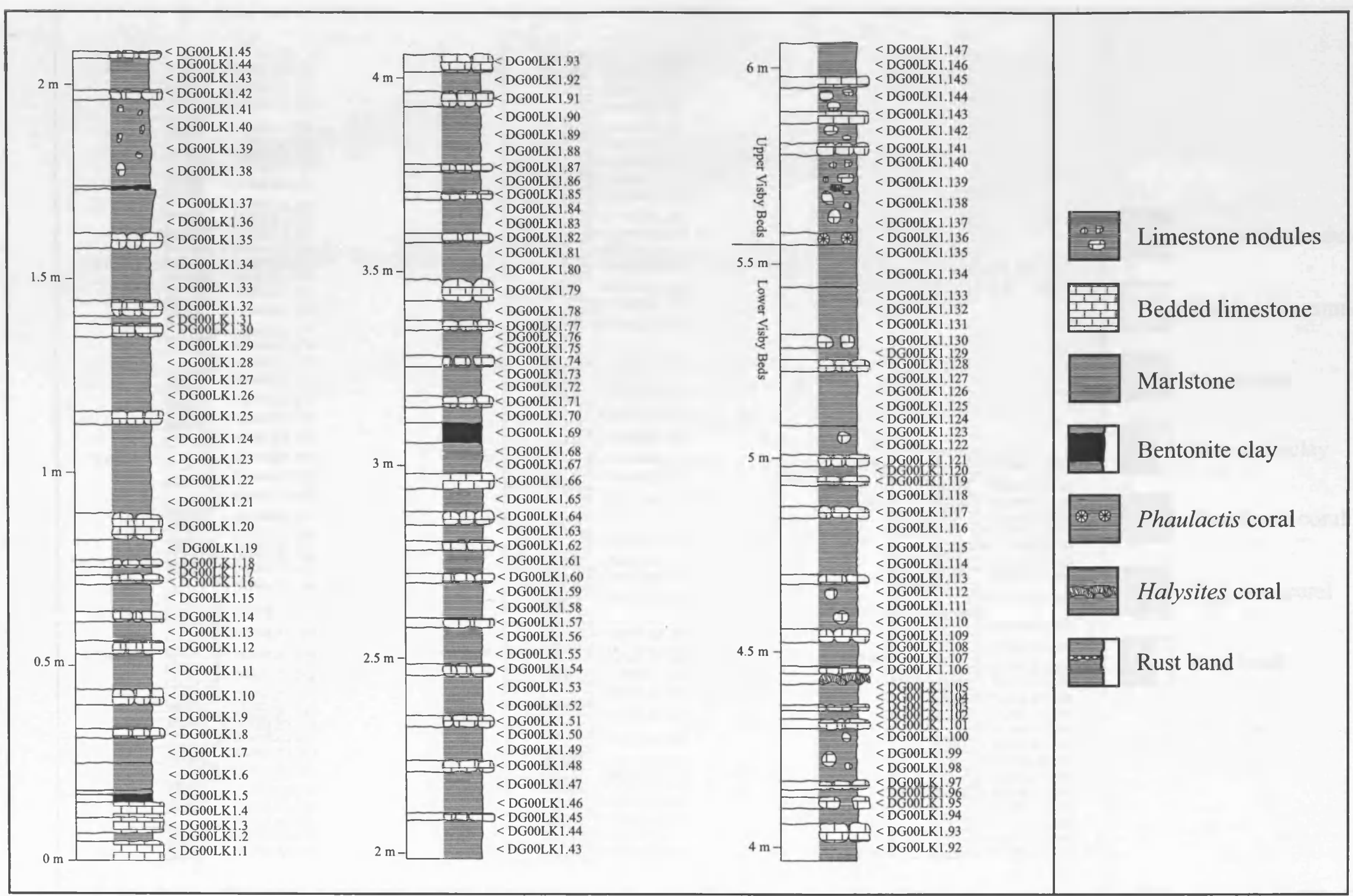

TEXT-FIG. 1.5 Stratigraphic log of the lower part of the Lusklint 1 section. The positions of the samples are shown. Figures refer to the height in metres above the base of the section (reference level is the base of the lower bentonite $0.15 \mathrm{~m}$ above the base of this section). The section is divided on the basis of bedding planes. 


\begin{tabular}{|c|c|c|c|c|c|c|}
\hline $7.5 \mathrm{~m}-$ & 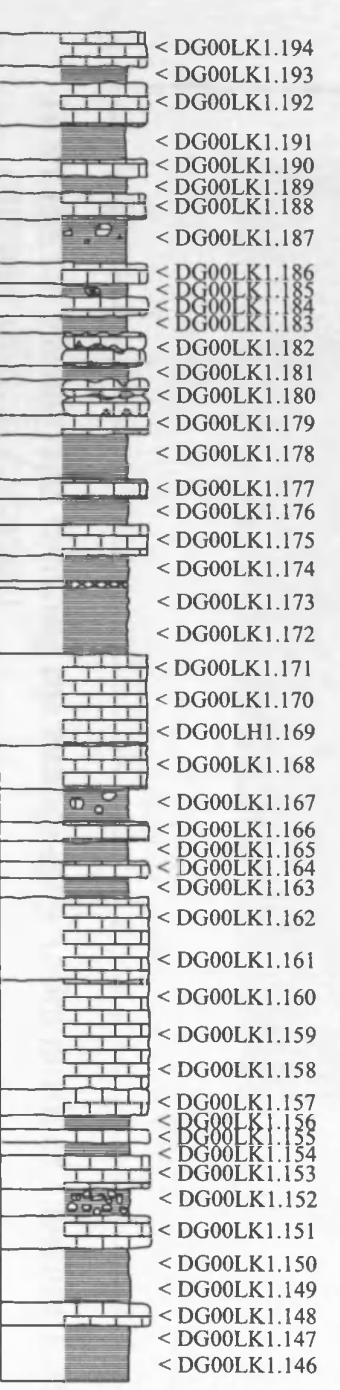 & $10 \mathrm{~m}-$ & 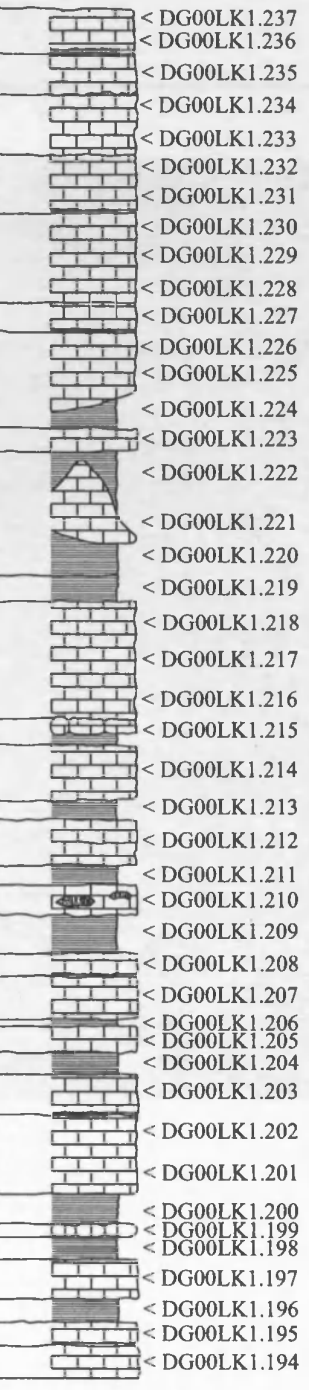 & $10.5 \mathrm{~m}$ & 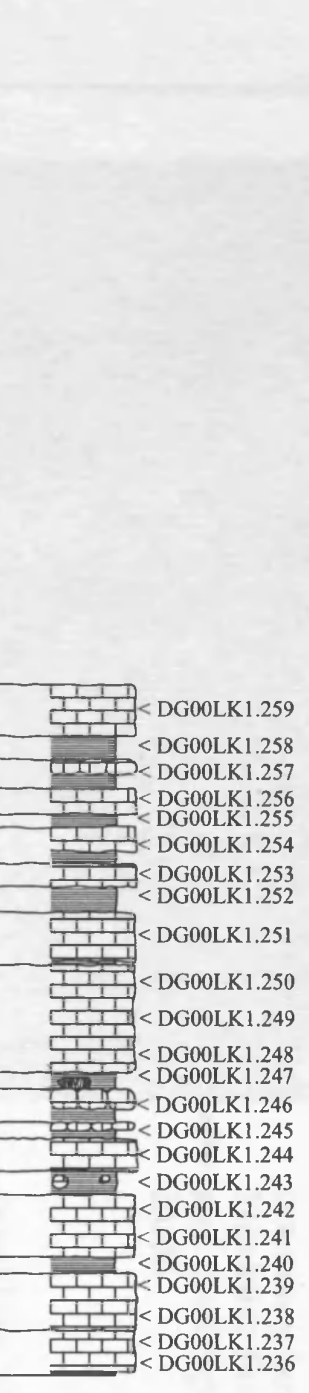 & $\begin{array}{l}\text { Bimestone nodules } \\
\text { Barlstone } \\
\text { Phaulactis coral } \\
\text { Halysites coral }\end{array}$ \\
\hline
\end{tabular}

TEXT-FIG. 1.6. Stratigraphic log of the upper part of the Lusklint 1 section. The positions of the samples are shown. Figures refer to the height in metres above the base of the section (reference level is the base of the lower bentonite $0.15 \mathrm{~m}$ above the base of this section). The section is divided on the basis of bedding planes. 


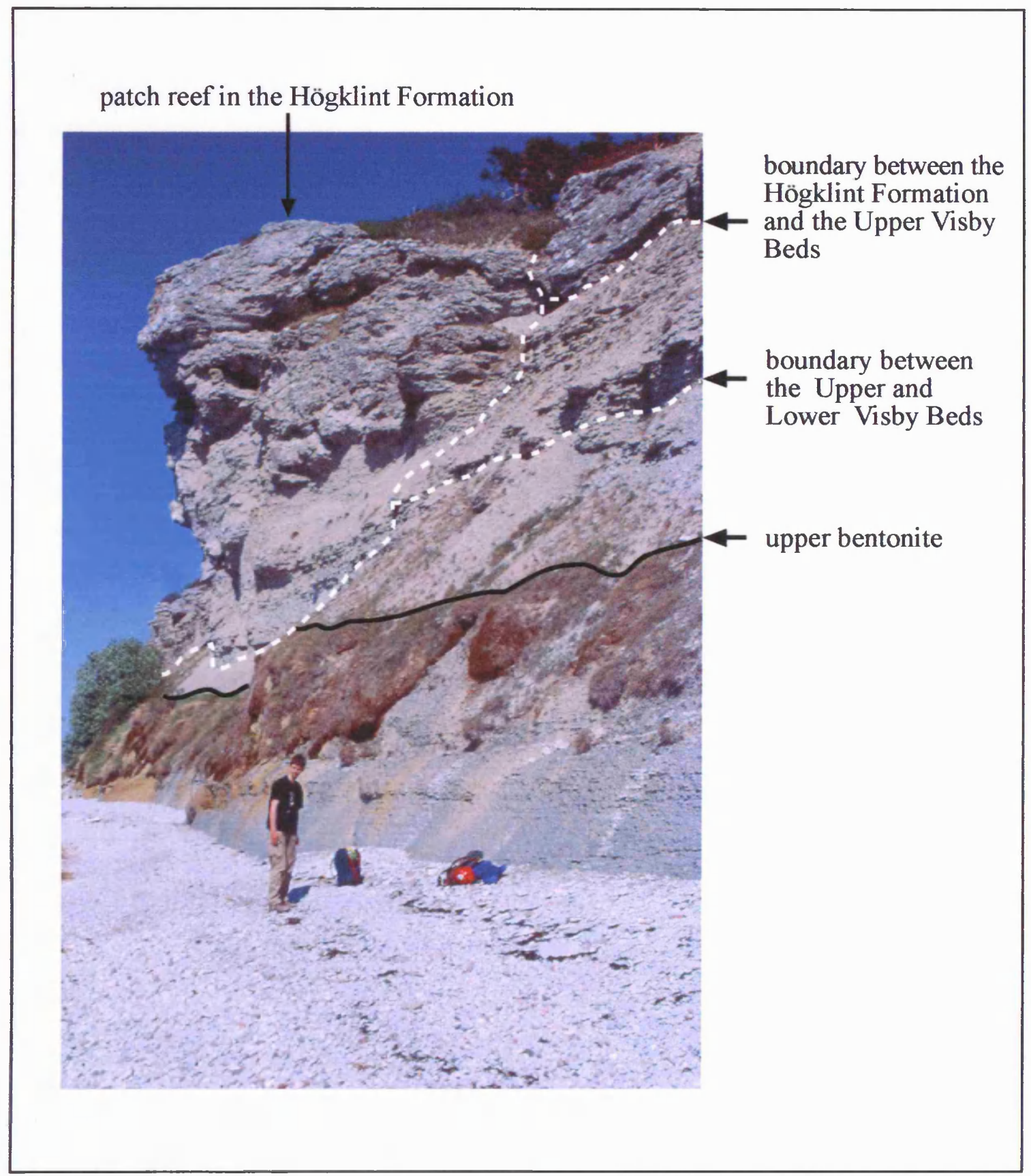

TEXT-FIG.1.7. Photograph showing the stratigraphy $150 \mathrm{~m}$ north of Lusklint 1. (Photograph courtesy of R. J. Aldridge). 
the cliff (600m south of Lusklint) the path is followed northwards into the pine forest. About $40 \mathrm{~m}$ north of the quarry boundary the path branches (not marked on the map) and one branch descends to the shoreline. The locality begins where the travertine cover on the cliff has eroded away. The section sampled is about $150 \mathrm{~m}$ north of where the path descends to the shore and $10 \mathrm{~m}$ south of the old pine tree, situated two-thirds of the way down the slope. This section from the base to the top of the cliff displays the transition from the marlstone dominated Lower Visby beds to the limestone dominated Upper Visby beds. The section forms a subcrop and for this study the topsoil was removed to a depth of about $0.4 \mathrm{~m}$ where the rock was exposed. Increasing thickness of the topsoil inhibits the collection of the higher parts of the Upper Visby beds and the Högklint Formation at this locality. The reference level is the base of the Lusklint bentonite (the lowest of the three) at $8.28 \mathrm{~m}$ above sea level.

\section{Lickershamn 2.}

(CK 5199 1239); Text-figs. 1.1, 1.4., 1.8., 1.9. A stream section cutting into the cliff, $4080 \mathrm{~m}$ north-west of Stenkyrka church. The section is $100 \mathrm{~m}$ west of the small bridge at the coast, about $260 \mathrm{~m}$ northwest of the northwestern-most house at Lickershamn. This section displays the sharp change between the limestone-marlstone alternations of the Upper Visby beds and the massive limestone of the Högklint Formation. The reference level is at the base of an inconspicuous weathered clay layer $1.9 \mathrm{~m}$ below the base of the Högklint Formation. 


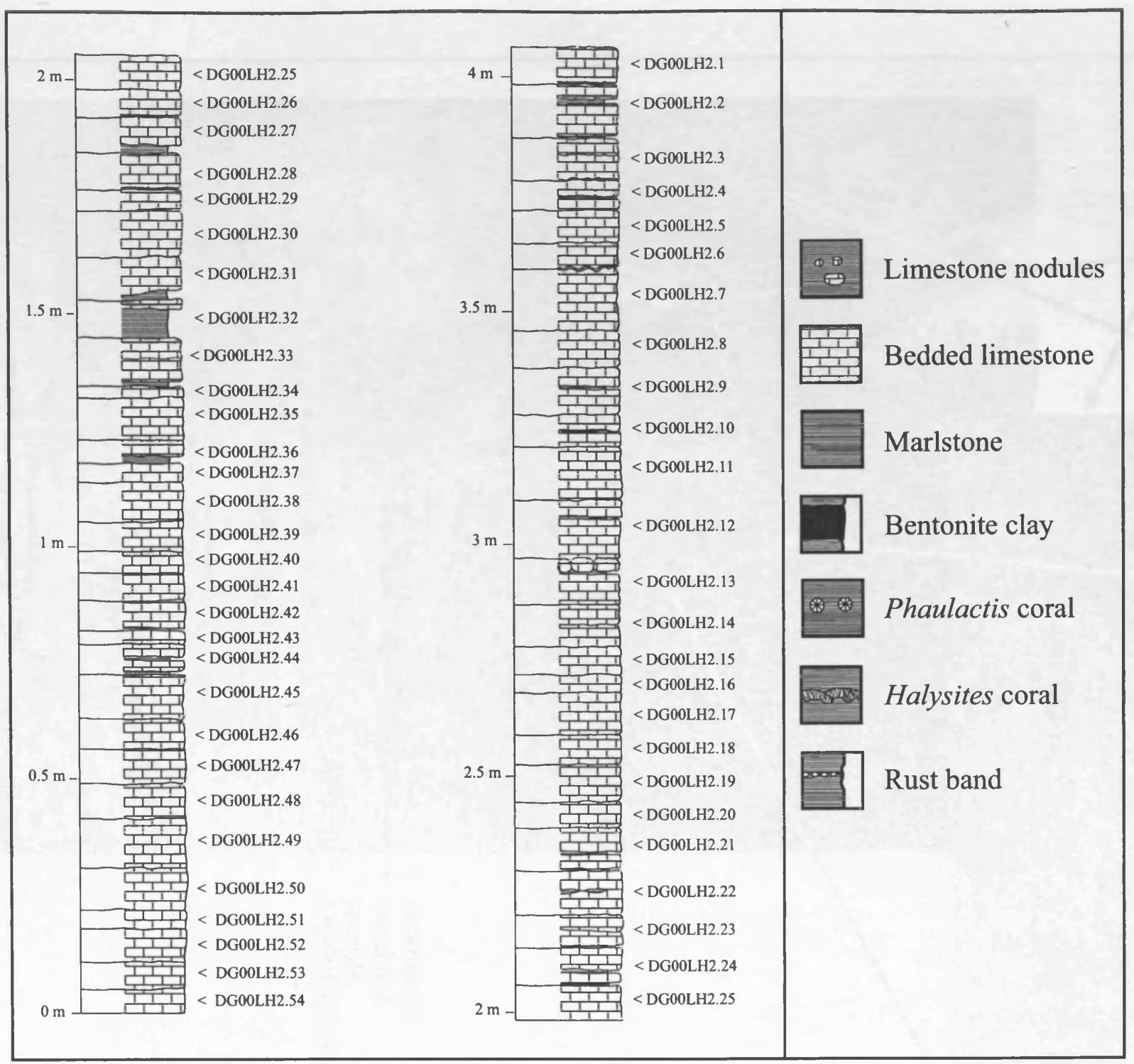

TEXT-FIG. 1.8. Stratigraphic log of the Lickershamn 2 section. The positions of the samples are shown. Figures refer to the height in metres above the bottom of the sampled section (the section base is $5.97 \mathrm{~m}$ below the clay reference layer). 


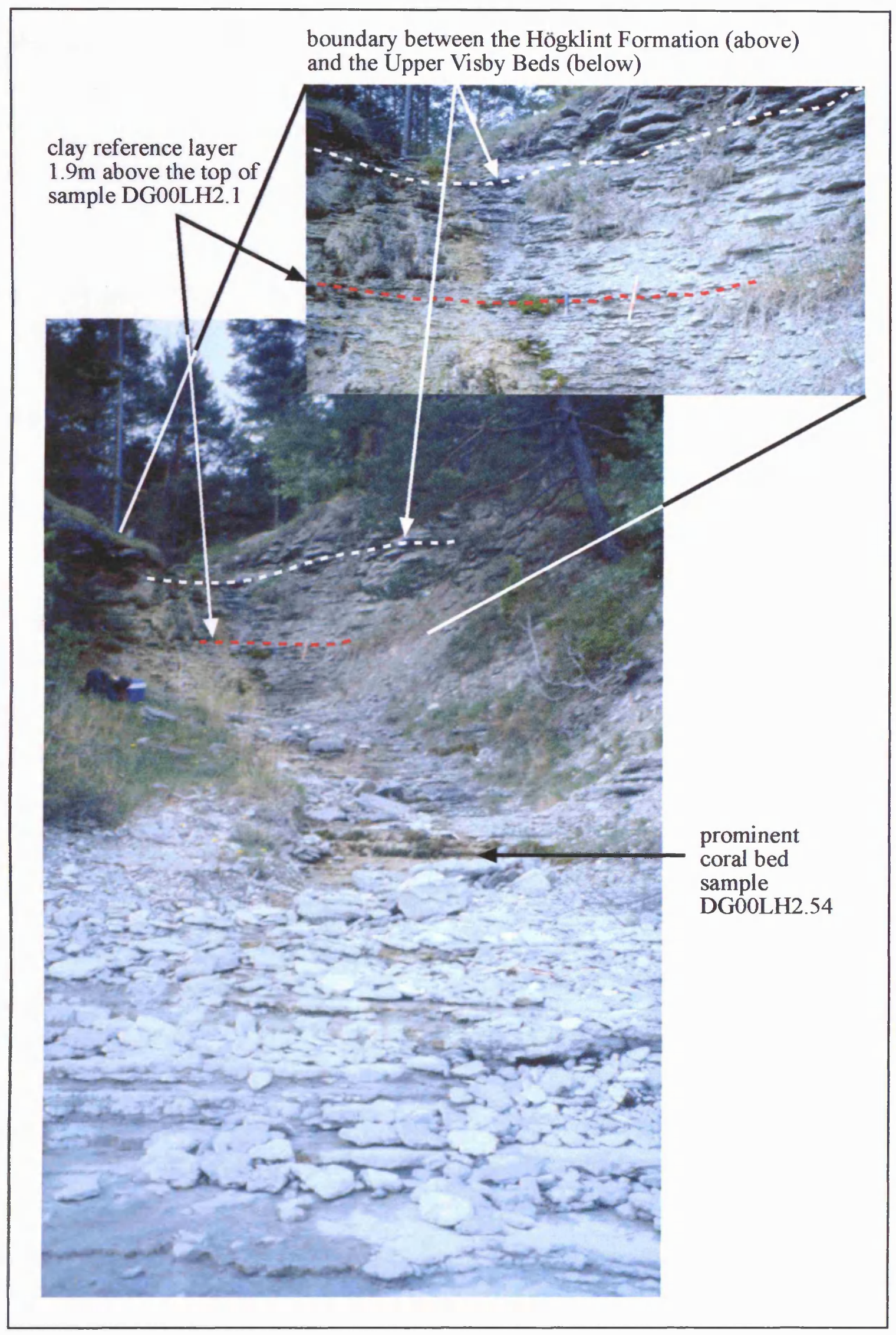

TEXT-FIG.1.9. Photo showing the stratigraphy at Lickershamn 2. 


\section{Techniques}

\section{Sampling technique}

At both Lusklint 1 and Lickershman 2 sampling strategy was dependant on lithology and bed thicknesses. Where marls were exposed the beds could be easily split, this was not the case for the limestone units for which sample thickness was mostly determined by bed thickness. At Lusklint 1 , samples were collected on average every five centimetres and at Lickershamn 2 roughly every ten centimetres, as this section was dominated by thicker limestone units. About one hundred grams of sediment was collected at each sample horizon and great care was taken to avoid contamination from other samples and organic debris.

\section{Testing of palynological processing techniques}

\section{INTRODUCTION}

The foundation to any palynological research is processesing technique. The method must be reliable, consistent and accurate, so that biostratigraphical or palaeoecological data are meaningful. Although the processing method is often specifically tailored to the sample being analysed and the equipment available, it is important to maintain some constant factors and to quantify the losses experienced. Consistency of processing technique is the most important factor, so that samples can be compared.

Several publications outline techniques used in extracting palynomorphs from rock. These reviews include Funkhouser \& Evitt (1959), Gray (1965), Barss \& Williams (1973), Forster \& Flenley (1989), Litwin \& Traverse (1989), and Wood et al. (1996). Colbath (1985) is the only author who used Silurian material to compare some of the extraction techniques available.

This chapter focuses on the errors that may be introduced during the extraction of palynomorphs from rock. The palynomorph assemblages from the lower Wenlock of Gotland (Sweden) provide a large number of species and relatively high numbers of palynomorphs per gram of sediment, with a very low thermal alteration and only occasional pyrite growth. These factors mean the material is ideally suited to the testing of processing procedures.

The small size of palynomorphs and the techniques used for their removal from the mineral fraction mean that specimens are likely to be lost or gained (as contamination) during the processing of the samples. Specimens may be lost when the organic residue is separated from the mineral fraction using centrifuge separation with sodium polytungstate or other heavy liquid. Pyrite present in the fossils will increase the mass of the specimens, and the mineral 
residue may clump around specimens (individuals with numerous processes may act as debris traps). Specimens may be lost through the sieve when washing the sample (regular tests can monitor any loss). A $7 \mu \mathrm{m}$ sieve was used because processing at $5 \mu \mathrm{m}$ is not time-effective. General human errors will also provide a source of loss, as some acritarchs may remain on the surface of equipment through inadequate recovery. Errors may also arise in the recording of data. A sample may gain specimens if it incorporates acritarchs that remain on the surface of equipment from the processing of previous samples.

Pyrite is present in the samples collected from Gotland. The pyrite grains slightly distort the specimens and may disguise some of their diagnostic features, such as plugged processes. This is not usually a problem, however, as the specimens are not totally enveloped in pyrite and can be identified accurately (Pl. 1, figs 1 and 2). The main problem created by pyrite is encountered during the separation process. Separation by heavy liquid depends upon the different densities of the acritarchs and the mineral portion of the sample. Any specimens with an increased mass due to the presence of pyrite (specific gravity 4.95-5.35) are, therefore, more likely to be forced into the lower part of the centrifuge tubes along with the mineral fraction. Even after treatment with nitric acid some specimens (especially those with large cavities such as Schismatosphaeridium (Pl. 1, fig. 2)) still contain pyrite grains. This may be due to the grains being protected from the nitric acid by the acritarch vesicle, or possibly insufficient time in the acid, or insufficient acid concentration. The presence of these specimens in the slides shows that a number were not pulled down with the mineral fraction; this may be due to their large relative size compared to their weight. Problems may result from any variations of pyrite content from sample to sample, with more specimens possibly lost in pyrite rich horizons.

The purpose of the processing technique is to provide samples where variations of species abundance and diversity, and numbers of palynomorphs per gram of sediment can be recorded. The processing should reflect these requirements and should aim to give the most accurate representations of the true values. It is important that the processing technique should be such as to minimise any artificial errors or biases in these observations. 


\section{PROCESSING TECHNIQUE}

- Wash and scrub the sample to remove lichen, fungi and other recent contaminants.

- Dry the sample in an oven to remove all moisture.

- Crush the sample to pea-sized fragments, using a sterile metal fly-press crusher.

- Weigh sample for processing (40 g) and put in to a polypropylene container with a screw top lid.

- Add $\mathrm{HCl}(32 \%)$ to remove the carbonate minerals, then decant three times to remove $\mathrm{Ca}$ and $\mathrm{Mg}$.

- Add HF (40\%) to the sample to remove the silicate mineral.

- Once the mineral portion of the sample has broken down, the acids are diluted with water until the sample bottle is full. When the mineral and fossil material has settled to the bottom of the bottle pour off the dilute acid, whilst ensuring no sample is lost. Repeatedly dilute the acid and pour off until the sample is neutralized. This needs to be carried out after each acid stage.

- Separate the sample by centrifuge at $2400 \mathrm{rpm}$ for 14 minutes to remove the water.

- Pour the water off the sample.

- Mix the sample in a $50 \mathrm{ml}$ centrifuge tube with $7 \%$ nitric acid to the $30 \mathrm{ml}$ mark and leave for 10 minutes at room temperature to remove the pyrite.

- Concentrate the sample by centrifuging at $2400 \mathrm{rpm}$ for 14 minutes.

- Pour the nitric acid off the sample.

- Mix the sample with sodium polytungstate (S.G. 2.0) to the $30 \mathrm{ml}$ mark on the centrifuge tubes and separate off the organic residue by centrifuging for 14 minutes at $2400 \mathrm{rpm}$.

- Remove the organic residue from the sample by pipetting or pouring off the topmost sodium polytungstate into a $7 \mu \mathrm{m}$ Nylon square mesh sieve.

- Wash the residue with 1.5 litres of deionised water and pipette into a $5 \mathrm{ml}$ container. Then, from the thoroughly mixed residue remove three portions of $0.05 \mathrm{ml}$ and place onto $22 \times 22 \mathrm{~mm}$ cover-slips, adding a few drops of cellosize to disperse the palynomorphs.

- Pass the remaining residue through a $53 \mu \mathrm{m}$ sieve to remove the chitinozoans and large acritarchs, and then a $7 \mu \mathrm{m}$ sieve, and mount the $53 \mu \mathrm{m}$ and $7 \mu \mathrm{m}$ residues separately, adding a few drops of cellosize. 
- At room temperature slowly evaporate the water from the cover slips to avoid particle clumping.

- Mount the cover-slips onto glass slides using Petropoxy 154. A drop of Petropoxy is placed on the dry cover-slip, which is then overturned, slowly lowered onto the glass slide and heated to $120^{\circ} \mathrm{C}$ until the Petropoxy has set.

- Thoroughly wash the equipment before and after each use.

\section{TESTING THE PROCESSING TECHNIQUES}

Before the samples can be analysed for numbers of palynomorphs per gram of sediment and species diversity, it is important that the possible sources of error in the processing technique are minimised and quantified. To this end a series of tests was carried out on three samples, DG00LK1.258, 257 and 255.

- To test for the effectiveness in removing acritarchs from the mineral residue at each separation by heavy liquid, and for any species biases in these separations, the sample DG00LK1.258 was separated by centrifuging at $2400 \mathrm{rpm}$ for 14 minutes in sodium polytungstate. The residue was pipetted off and the resulting acritarchs sieved, mounted and logged. This provided a record of the numbers of palynomorphs recovered per gram of sediment after the first separation and the number and type of species that were seen at this stage. To quantify the number of acritarchs not recovered during the first separation, the dense residue at the bottom of the centrifuge tube was again mixed with sodium polytungstate and re-separated. The material removed from the second separation was logged in the same way as the first. This was repeated a further four times.

- To test the impact of the use of nitric acid for the removal of pyrite on the final assemblage composition, the sample DG001.257 was prepared using nitric acid before it was separated by centrifuging. The resulting slides were then logged for numbers of palynomorphs per gram of sediment and number of individuals of each species present. As a control, a further portion of the DG00LK1.257 was then processed using the same technique, but without nitric acid preparation and logged in the same manner. The results for the two samples were compared to quantify the effectiveness of the nitric acid treatment.

- To test the risk of loss of material through the $7 \mu \mathrm{m}$ sieve, the fraction of sample DG00LK1.255 (along with samples 258 and 257) less than $7 \mu \mathrm{m}$ was mounted and 
analysed. This was carried out by saving the washings from the $7 \mu \mathrm{m}$ sieve and leaving them to settle in a sample bottle so that the water and sodium polytungstate could be poured off. The remaining material was then mounted onto cover-slips. This enabled the acritarchs penetrating the sieve mesh to be counted and analysed for preferential removal of particular species.

- To test the reliability of the volume method in estimating the number of acritarchs per gram of sediment an alternative method, the Lycopodium spores method was analysed. The number of acritarchs per gram of sediment in sample 255 was first calculated by counting the number of acritarchs in $10 \%$ of the volume of the total residue of the sample and then calculated up to give the number of acritarchs present in the whole sample, this was then divided by the weight of the sample to give the number of acritarchs per gram of sediment. Secondly a repeat of the same sample was undertaken, but this time a Lycopodium spore tablet was added. The Lycopodium spore tablets contain a known number of spores. If the number of spores encountered is noted whilst the sample is being logged, it can be used to calculate the number of acritarchs per gram of sediment, using the proportion of acritarchs to spores.

- To test how often recent contaminants occur in a sample and the likelihood of mistakenly identifying them as acritarchs, three slides were prepared using only deionised water. The occurrence, size and morphology of contaminants was noted.

\section{RESULTS OF REPEAT SEPARATION}

To obtain meaningful results the following questions must be answered: does the apparent diversity of a sample change between repeat separations? Is there a consistent gradual increase in the numbers of acritarchs per gram of sediment calculated, or are there an optimum number of separations after which the change in number of acritarchs per gram of sediment calculated becomes negligible? At first, sample DG00LK1.258 was separated three times, but the results proved inconclusive. To test that a consistent and representative sample was present when three separations had been carried out, it was decided to repeat the test, but mounting the recovered residues for six separations.

The number of acritarchs per gram of sediment was calculated by reducing the volume of the organic residue from a sample of known weight (usually 40 grams) to $5 \mathrm{ml}$. From this $5 \mathrm{ml}$ three representative $0.05 \mathrm{ml}$ portions were removed after thorough mixing. These $0.05 \mathrm{ml}$ portions were mounted onto glass slides using the methods outlined above and the number of 
acritarchs in each was recorded and the average calculated. This average figure, which represents the number of acritarchs in $1 \%$ of the sample, was then multiplied by 100 and divided by the weight of the sample to give the number of acritarchs per gram of sediment.

The first separation of sample DG00LK1.258 yielded 2620 acritarchs per gram of sediment, the second 1708, the third 1081, the fourth 733, the fifth 801 and the sixth 264 (fig. 2.1). For separations 1 to 4 there was a drop of around $35 \%$ in each separation, the fifth separation has slightly more than the fourth, but the drop resumes in the sixth.

These data suggest that mixing of the mineral residue to release the acritarchs from the mineral is extremely important. After one separation the calculated number of acritarchs per gram is a considerable underestimate of the population in that sample. The cumulative addition of the residues from repeated separations reduces this error. The mixing between separations should re-suspend as much of the mineral matter as possible back into the sodium polytungstate, even though it can be difficult disperse the lumps of sample.

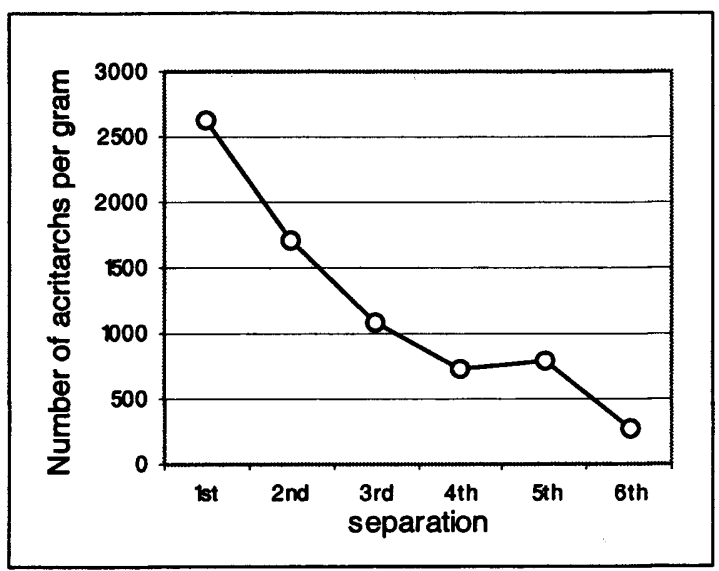

Text-fig. 2.1, Total number of palynomorphs per gram of sediment recorded in each separation procedure when carried out 1-6 times, sample DG00LK1.285.

The assemblage seen in sample DG00LK1.258 is dominated by Micrhystridium stellatum at an average across the six separations of $24.2 \%$, with $11.38 \%$ Veryhachium trispinosum, Leoisphaeridia (small $(<29 \mu \mathrm{m})$ thin walled) at $8.6 \%$ and Diexallophasis gotlandica at $7.38 \%$.

The relative proportion of each acritarch subgroup (subgroups of Downie et al. 1963) changes by only a small amount between the first separation and the sixth (fig. 2.2). The variation is greatest in the acanthomorph group, which at its highest makes up 53.9\% of the assemblage, in the second separation, falling to a low of $36.3 \%$ in the sixth. The sphaeromorph acritarchs 
begin and end the test at around $25 \%$ of the whole assemblage, but drop to $17.4 \%$ and $20.1 \%$ at the third and fourth separations respectively. The polygonomorph acritarchs appear to reach a plateau at around $22 \%$ of the whole assemblage in the $3^{\text {rd }}$ to $6^{\text {th }}$ separation, after a rise from $10.4 \%$ in the first separation to $12.1 \%$ in the second. The herkomorph prasinophytes vary little after their drop from $13.2 \%$ to $6.4 \%$ from the first to the second separation, and the netromorphs maintain a gradual rise from $2.8 \%$ of the assemblage in the first separation to 7.4\% in the sixth. The rarer 'Estiastra subgroup' shows almost no variation.

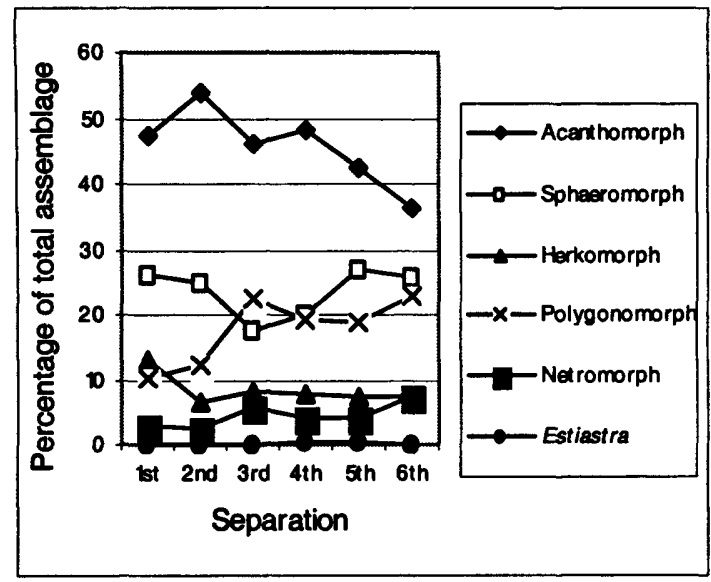

Text-fig. 2.2, Percentage abundance of each acritarch subgroup recorded in each of the six separations, sample DG00LK1.285.

The relative frequencies of genera (fig. 2.3) have also been plotted, ignoring those taxa which fall below $2 \%$ of the total assemblage. The $<2 \%$ data plot as noise and patterns are difficult to distinguish.

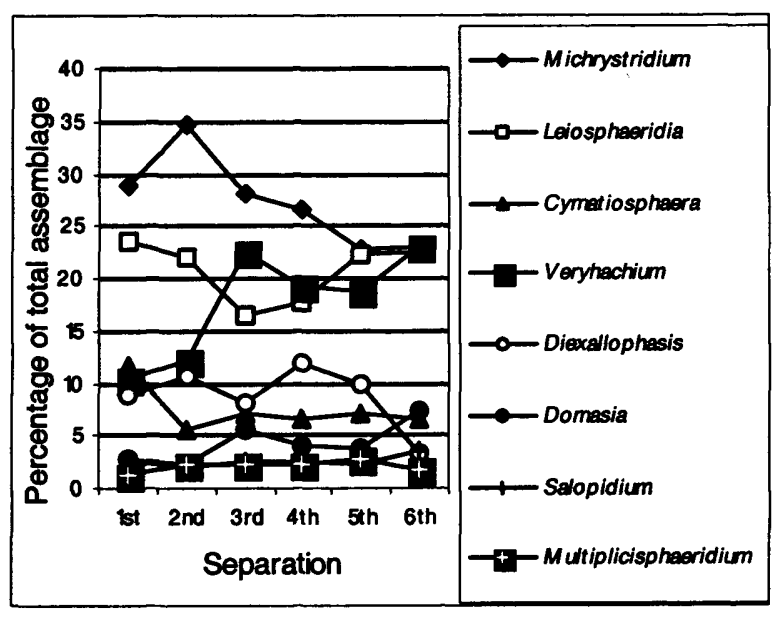

Text-fig. 2.3, Percentage abundance of each acritarch genus recorded in each of the six separations, sample DG00LK1.285. 
The relative frequencies of Micrhystridium, Leiosphaeridia and Veryhachium show very similar plots to those seen for the acanthomorphs, the sphaeromorphs and the polygonomorphs respectively. This is not surprising as they are the dominant genera in these subgroups. However, Diexallophasis appears to maintain a near constant percentage abundance until it falls from $9.8 \%$ in the fifth separation to $3.4 \%$ in the sixth. Cymatiosphaera maintains a level of around $7 \%$ of the assemblage, after a fall from $11.6 \%$ recorded in the first separation. Domasia, Salopidium, and Multiplicisphaeridium vary little from separation to separation, with Domasia only rising from $2.8 \%$ to $3.4 \%$ and Salopidium and Multiplicisphaeridium maintaining a percentage of around $2.6 \%$.

Very few species present in the population are not represented in the first three fractions (six very rare species recorded in this test). The main drawback of the heavy liquid separation procedure is that all the acritarchs in the sample are not removed by the third separation. A more accurate representation of numbers of acritarchs per gram of sediment would be achieved if the separations 1-6 were put together, but this increase in accuracy does not justify the extra time needed to complete six separations. The rarer species found when the sample was separated six times rather than three are also probably not significant enough to justify the extra time involved.

The recovery of acritarchs does not seem to be affected by any clumping of mineral matter around spinose genera, as the acanthmorph subgroup (fig. 2.2) actually shows a decrease in percentage removal as more separations are carried out and not an increase, which might be expected if they were mostly held in the mineral fraction during the initial separations.

\section{RESULTS FROM NITRIC ACID TESTING}

Sample DG00LK1.257 was treated with 7\% nitric acid for ten minutes. Only 7\% nitric acid was used to prevent the sample from being unnecessarily over-oxidized. A repeat sample of DG00LK1.257 was processed in an identical way, but without the nitric acid treatment. It is essential the sample is thoroughly mixed with the nitric acid as lumps of mineral clustered around any palynomorphs may protect the pyrite from attack. Samples not mixed properly may expose fewer pyrite grains to digestion and yield fewer palynomorphs. It is estimated that treatment with $7 \%$ nitric acid removed $30-40 \%$ of the observed pyrite. 
The sample treated with nitric acid yielded 4442 acritarchs per gram of sediment and the repeat sample (that had not undergone treatment with nitric acid) yielded 5325 acritarchs per gram of sediment. The yield of acritarchs in the sample treated with nitric acid is lower. The difference may be due to the nitric acid destroying or fragmenting the palynomorphs that contain pyrite while the pyrite is being digested. If the acritarch contains a split allowing the nitric acid to flow inside the vesicle, the reaction of the nitric acid with the pyrite may be violent enough to break up the vesicle. When calculating numbers of acritarchs per gram of sediment, specimens were only counted if more than half of the individual is preserved. Incomplete specimens, broken up by the reaction between nitric acid and pyrite, would therefore not increase the number of palynomorphs per gram of sediment calculated and could possibly decrease it if the broken specimens form fragments that are all less than half the original size.

If treatment with nitric acid has no effect, the acritarch subgroups should have a near identical percentage abundance in both the treated and un-treated samples. This is not the case, with the sphaeromorphs reducing in frequency from $40.9 \%$ to $30.8 \%$ and the herkomorphs reducing from $13.7 \%$ to $7.0 \%$ between the sample treated with nitric acid and the sample not treated with nitric acid (fig. 2.4). In contrast, the percentage abundance of acanthomorphs increases from $34.5 \%$ to $41.8 \%$ between the sample treated with nitric acid and the sample not treated with nitric acid, the polygonomorphs increase from $9.1 \%$ to $16.1 \%$ and the netromorphs from $2.1 \%$ to $4.4 \%$. These differences may be due to natural variability, or to the destruction of some individuals in some subgroups by nitric acid. It is important to emphasise that the increase in the percentage abundance of acanthomorphs, polygonomorphs and netromorphs in the sample not treated with nitric acid may just be a reflection of the relative decrease in the number of sphaeromorphs and herkomorphs extracted. 


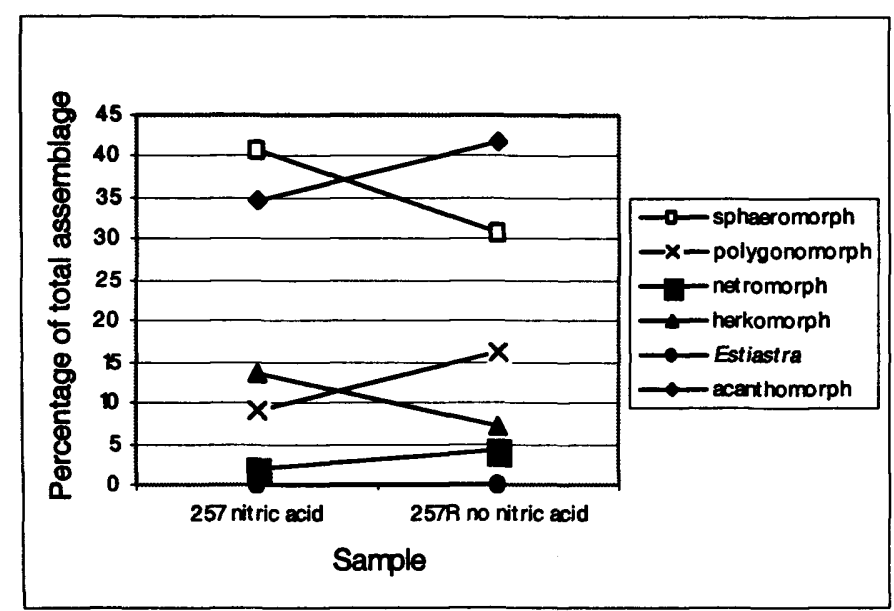

Text-fig. 2.4, Percentage abundance of each acritarch subgroup recorded in sample

DG00LK1.257 when the sample was treated with nitric acid and when nitric acid was not used during processing.

To investigate preferential pyrite growth in specific morphologies, the percentage of individuals containing pyrite in each subgroup was recorded after three separations of sample DG00LK1.258. The sphaeromorphs and the acanthomorphs contained the most pyrite, with $32.9 \%$ and $32.2 \%$ of the specimens showing its presence, $19.3 \%$ of the herkomorphs, $14.4 \%$ of the polygonomorphs and $1.2 \%$ of the 'Estiastra subgroup' contained pyrite grains.

\section{RESULTS OF $7 \mu \mathrm{m}$ SIEVE TEST}

The $<7 \mu \mathrm{m}$ fractions from samples DG00LK1.258, 257 and 255 were logged after three separations. Sample DG00LK1.258 yielded 30 acritarchs $(0.7<7 \mu \mathrm{m}$ acritarchs per gram of sediment), of which 29 were Leiosphaeridia spp., with one Veryhachium wenlockium. DG00LK1.257 yielded 33 acritarchs $(0.8<7 \mu \mathrm{m}$ acritarchs per gram of sediment), of which 24 were Leiosphaeridia spp., the remainder consisting of Domasia trispinosa, Veryhachium trispinosum, Diexallophasis gotlandica, Micrhystridium stellatum and Cymatiosphaera aff. ledburica. DG00LK1.255 yielded 23 acritarchs $(0.6<7 \mu \mathrm{m}$ acritarchs per gram of sediment), of which 12 were Leiosphaeridia spp., 5 were Veryhachium wenlockium, 3 were Micrhystridium stellatum, 2 were Domasia trispinosa and one was Micrhystridium irevikensis.

No species were identified that had not been recorded in the $>7 \mu \mathrm{m}$ fraction, indicating that the lost data have little influence on the final diversity results, and the loss in numbers of acritarchs is minimal. The acritarchs recorded are species that tend to be small and their size 
range would be likely to include specimens smaller than $7 \mu \mathrm{m}$. DG00LK1.257 included specimens of Diexallophasis gotlandica and Cymatiosphaera aff. ledburica which are larger than $7 \mu \mathrm{m}$; this is probably a result of contamination from the $>7 \mu \mathrm{m}$ fraction, or even from another sample.

\section{RESULTS FROM LYCOPODIUM SPORE NUMBERS PER GRAM OF SEDIMENT}

\section{TEST}

The number of acritarchs per gram calculated using the volume method was 11243 and the number of acritarchs per gram calculated using the Lycopodium spore method was 22160 . Nearly double value of calculated number of acritarchs per gram of sediment in the Lycopodium spore sample indicates the methods are not comparable. This is probably partially due to the low amount of Lycopodium spores counted. If more tablets had been added the numbers per gram would have been more accurate. It is impossible to say which of the two methods is nearest the true value as no control is available.

\section{RESULTS FROM THE MODERN CONTAMINANTS IN DEIONISED WATER TEST} The deionised water slides contain very sparse debris (Pl. 1. figs 3-5). It is usually in the form of amorphous organic fragments (Pl. 1, fig. 4), which are clearly distinguishable from the Silurian palynomorphs recovered in this project. The main problems may occur if any of these fragments obscure specimens. Plate 1 , figs 3 and 5 show debris that superficially resembles Baltisphaeridium type Silurian acritarchs. On closer inspection, these specimens show no real spherical vesicle and they are several times larger than most Silurian acritarchs.

\section{DISCUSSION}

The results from the repeat separation test show that the relative frequency of genera in the assemblages stabilises by the third separation. The variation seen in the fourth, fifth and sixth separations is probably due to low numbers remaining after the first three separations. A number of acritarchs do seem to remain after the third separation, but this does not appear to have an effect on the number of species recorded from a sample. The total number of acritarchs per gram of sediment is affected by factors such as sedimentation rate, preservation potential and current activity, as well as phytoplankton abundance. The difficulty in obtaining any extra meaningful interpretations from the sample that was separated six times, suggests it is not time effective to spend overly long periods obtaining and recording data. It can be 
concluded that carrying out three separations provides a sufficiently representative assemblage and further separations do not significantly add to the accuracy and value of results.

Treatment with nitric acid caused a decrease in the number of acritarchs recovered per gram of sediment. The results show that herkomorph and sphaeromorph acritarchs are recovered more successfully when the sample is treated with nitric acid. The data suggest that acanthomorph and polygonomorph acritarchs are recovered more successfully if the sample is not treated with nitric acid, but this may well fall within the statistical limits of natural variation. The acanthomorph acritarchs show a fairly high occurrence of pyrite growth, suggesting that nitric acid reacting with the pyrite may have a detrimental effect on the occurrence of this subgroup. The polygonomorph acritarchs, which have a low occurrence of pyrite growth, show a decreased yield when treated with nitric acid.

From this test it can be concluded that treatment with nitric acid probably had little detrimental influence on the acritarchs recorded in sample DG00LK1.257. This may be due to the relatively low amount of pyrite present. The real influence of pyrite presence and nitric acid treatment on the recovery of palynomorphs should ideally be tested on many samples of various types and should involve precise quantification of the pyrite present. It is suggested that to reduce problems associated with pyrite, nitric acid treatment should be routinely adopted in sample processing. This will make the species diversity and numbers of acritarchs per gram of sediment of pyrite rich and pyrite poor samples more comparable. The degree of possible destruction of acritarchs during the growth of pyrite grains larger than the specimens cannot be calculated and must be considered as a factor when analysing pyrite rich horizons.

The $<7 \mu \mathrm{m}$ sieve test data indicate that the loss of acritarchs during washing of the sample through a $7 \mu \mathrm{m}$ sieve is minimal and can be considered as a minor factor, that can be monitored by regular testing.

In the absence of a control, it is very difficult to compare the Lycopodium spore method and the volume method in calculating the most accurate number of acritarchs per gram of sediment. 
The use of Lycopodium spores has the advantage of greater speed in processing and logging. Fewer slides have to be prepared and any volume can be used for mounting on a cover slip (avoiding having to reduce the residue down to $5 \mathrm{ml}$ ). Only one slide needs to be logged, as opposed to three slides in the volume method and then the diversity logged separately. The inaccuracy of the volume method (variations in the number of acritarchs removed in the numbers per gram fractions) is avoided.

However the values generated by the counting of Lycopodium spores have numerous inconsistencies, which render them inferior. The number of Lycopodium spores in a single tablet is innately inaccurate. The introduction of the spores to the sample adds an extra variable to the processing technique. This may change the dynamics of the sample during processes such as the settling of material through the water in the sample bottle and the digestion in acid. If samples are particularly sparse in palynomorphs large numbers of Lycopodium spores would need to be counted for each acritarch encountered. Finally Lycopodium spores are less widely used during counting, introducing unnecessary inconsistencies when comparing data with those of other workers. If time permitted, further tests would be carried out with repeat sampling for greater numbers of tablets, to test where the threshold of consistency for numbers per gram is achieved. Then a more realistic comparison to the volume method could be made.

The volume method is by no means perfect, but it is thought that the variables encountered during the Lycopodium spore numbers per gram method are greater than those encountered during the volume method. Consistency of processing technique is the most important factor.

\section{CONCLUSIONS}

Two important points that emerged from Colbath's (1985) investigations still remain: consistency of technique and the trade-off between the accuracy of results and the time incurred in obtaining them. $100 \%$ repeatability of results is unlikely to be achieved; repeat sampling of modern biological communities gives a certain percentage of random variation (Watkins et al. 1990, Muylaert et al. 2000). Population variability and errors associated with repeat sampling, such as differential preservation and uneven distribution of palynomorphs within the rock sample mean that repeatability is never perfect. Variations in apparent diversity may result from the recording of species represented by very few individuals, which may be seen in one sample, but not the next. Consistency in the processing technique reduces 
errors as much as possible and the accuracy of estimates of the number of palynomorphs per gram of sediment and of the number of species present are very important. It is very unlikely every acritarch can be extracted from a rock sample. Even if every acritarch could be extracted, the time incurred in recording all the individuals could not be justified for the increase in the accuracy of the results. Three separations, nitric acid treatment and well monitored sieving, provide a justifiable compromise between the time spent processing and the precision of the results. A similar conclusion may apply to other palynological assemblages.

This study has suggested that the losses incurred at various stages in the processing technique are significant, but can be reduced and quantified. Although palynological samples from different localities and time periods will yield different numbers of palynomorphs per gram of sediment and different species, tests should be carried out as appropriate to quantify the loss of data.

\section{Logging technique}

Firstly, 250 specimens were counted from a representative portion of the sample. A rarefaction curve of number of species against number of specimens was then plotted. If a plateau had not been reached at this stage, the count continued until this was achieved. At this point, the percent abundance of each species was calculated. The species were then ranked in order of frequency. Starting with the most common species, the cumulative percent abundance was calculated until approximately $45 \%$ of the total assemblage was reached. This enabled the most common taxa to be identified. The remainder of the sample continued to be logged, but the common species were no longer recorded, until a count of 1000 specimens (including the predicted values) was reached.

\section{Photographic technique}

Palynomorphs recovered from samples collected in stable cratonic areas have often undergone little thermal alteration (TAI 1.5 (Traverse, 1988)). This is of benefit to the taxonomist as fragile diagnostic characters are often well preserved. Unfortunately, when the specimens are photographed under a light microscope they often contrast poorly with their backgrounds. 
The palynomorphs recovered from the lower Silurian of Gotland typify these problems; they show excellent preservation of fine detail, but have a very low contrast to the background under light microscopy. To increase this contrast a new technique has been developed whereby a portion of the residue is heated to increase the thermal alteration. This enables the specimens to be more easily identified on photographs, whilst not overheating and damaging the palynomorphs. Staining with safranine or other dyes can give variable results, with some specimens absorbing the stain whilst others remain unaffected.

Samples were processed using standard palynological processing techniques (Gelsthorpe 2002), logged and the number of palynomorphs per gram of sediment recorded. Part of the remaining residue was then mixed with two drops of cellosize to disperse the specimens (high concentrations of cellosize readily burns, obscuring the specimens). This mixture was then evenly spread over the required number of coverslips and left to evaporate at room temperature. Once evaporated, the cover slips were heated to $200^{\circ} \mathrm{C}$ on a hotplate for 30 minutes. To achieve this temperature it was usually necessary to cover the cover slips to insulate them from room temperature (a household baking tray was found to be adequate). Once the cover slips had cooled they were mounted and labelled in the normal way. Examples of specimens of the same taxa heated and unheated, are illustrated in Plate 1, figs 6-9.

It could be argued that once the samples have been artificially heated they are so altered that it is inappropriate to compare them to unheated samples or samples from other localities. This may be the case, but as long as the samples are prepared and logged in the normal way prior to heating (as is suggested here), these problems are avoided. Scanning electron micrographs showing highly detailed high contrast photographs are commonly used in palynological publications, but a method of high quality light microscope photography is still necessary. Light microscopes are routinely used for logging samples and some diagnostic features such as wall thickness and plugged processes can only be identified under transmitted light.

Many of the palynomorphs illustrated herein have not undergone the treatment outlined above, as they are so rare that specimens have not been relocated on treated residues. Those that have undergone heating are identified by the initials 'ckd' in the sample name. 


\section{Acritarch and Prasinophyte algal classification}

The informal group Acritarcha Evitt (1963) comprises organic walled, unicellular microfossils of 'unknown and probably varied biological affinities' (Evitt 1963). Many acritarchs are probably algal (Downie 1973, Martin 1993, Colbath and Grenfell 1995, Servais et al. 1996). There is a large variation in size and morphology between genera. Silurian acritarchs range in size from Michrystridium stellatum Deflandre, 1945 at $10 \mu \mathrm{m}$ across, to

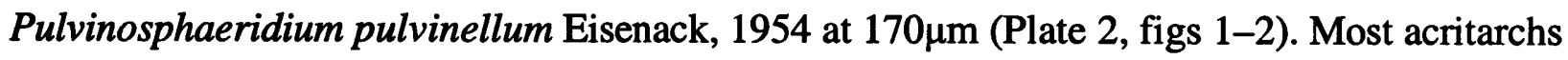
and prasinophyte algae have a spherical to subspherical vesicle (Plate 2, fig. 3 ) with or without ornament on the surface (Plate 2, fig. 4), some possess membranes perpendicular to the surface (some of the prasinophyte algae) (Plate 2, fig. 5) and some possess simple or branched processes (Plate 2, figs 6-7). Vesicle shape varies from spherical, to fusiform, to triangular (Plate 2, figs 3, 8-9). The wide variation in acritarch and prasinophyte algal morphology and size is a constant problem when trying to identify interspecific and intraspecific characters.

It has been suggested by Pirozynski (1976) that Palaeozoic acritarchs may be related to spores of oomycete fungi. The possibility of a fungal origin has been given little attention in the literature, but Colbath and Grenfell (1995) suggested the present morphological and chemical evidence implies that acritarchs are not fungal. Dorning (1981a) suggested that because of the association of some of the large acritarch genera (Hogklintia, Estiastra and Pulvinosphaeridium) with carbonate reef complexes, these particular taxa may be benthic thallose macroalgae. This was disputed by Colbath and Grenfell (1995) as these forms bear little resemblance to modern macroalgae. The discovery of triaromatic dinosteroids in Precambrian to Cenozoic rocks by Moldowan et al. (1996) suggests that some acritarchs probably belong to the same clade as dinoflagellates. A specific set of sterol chemicals (including dinosteroids) are associated almost exclusively with dinoflagellates. The good correlation between the presence of dinosteroids and the relatively high abundance of dinoflagellates and acritarchs in the fossil record forms the basis of the theory that they share a common origin (Moldowan et al. 1996, fig. 2c).

Prasinophyta algae are classified as green algae (modified by Colbath and Grenfell 1995 from Tappan 1980), for which there is a much greater biological understanding than for the acritarchs. Many prasinophytes have a distinct flange or flanges, which is equatorial or 
CHAPTER 3

together forms a hexagonal pattern. Prasinophyta have many morphological similarities to the genus Leiosphaeridia Eisenack, 1958a (a genus which is probably polyphyletic), some forms of which may be included in the prasinophytes. Without further work, Leiosphaeridia affinities are disputable (Colbath and Grenfell 1995).

Acritarchs and prasinophyte algae are treated under the International Code of Botanical Nomenclature (Deflandre 1936, Downie et al. 1961, 1963). Herein, acritarch genera are listed in alphabetical order in accordance with generally accepted principles, so that inferences introduced by artificial classifications (e.g. Downie et al. 1963, 1973) are avoided.

Given the present level of understanding of acritarch classification, Colbath and Grenfell (1995, pp. 307) have suggested the Linnaean system is inappropriate. In an attempt to stabilize the informal subgroupings of acritarchs they have put forward three acritarch clades (Baltisphaeridium Eisenack, 1958b, Peteinosphaeridium Staplin et al.,1965, and Cymbosphaeridium Lister, 1970), which are defined on features such as wall and process structure and excystment mechanism. Colbath and Grenfell (1995, pp. 310) concluded that acritarchs which excyst utilizing a cryptopylome resemble dinocysts, but that they are sufficiently different to be grouped separately, as that they do not possess a paracingulum or paratabulation.

\section{SYSTEMATIC PALAEONTOLOGY}

\section{Terminology}

Details of the measurements referred to below are given in Text-fig. 3.1. Further glossaries of terms can be found in Lister (1970, pp. 24-26) and Williams et al. (1978). The excystment openings observed in Palaeozoic acritarchs have been described and illustrated by Colbath and Grenfell (1995, p. 306, pl. 18).

\section{Plate explanations}

Samples are labelled as follows: eg. DG00LK1.100npg1 (DG, the initials of the author; 00, samples were collected in the year 2000; LK1, locality Lusklint 1, or alternatively LH2, locality Lickershamn 2; 100 , the sample number; npg1, sample containing $10 \%$ of the residue and suitable for calculating the number of palynomorphs per gram of sediment). The location of individual specimens on a slide is given as an England Finder reference. The location of specimens photographed using the scanning electron microscope is recorded using the grid system shown in Text-fig. 3.2. 


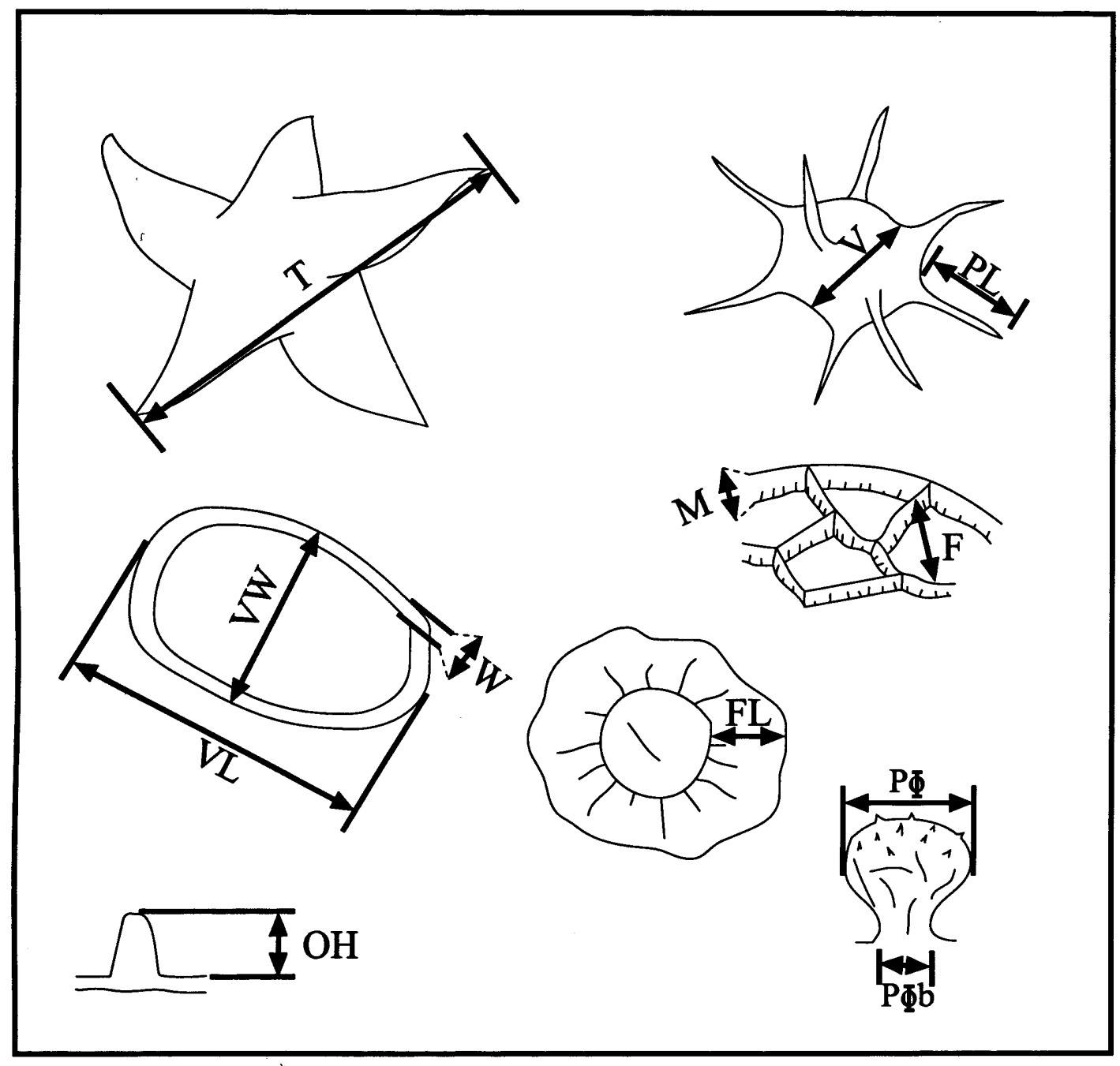

TEXT-FIG. 3.1. Examples of the positions of the measurements referred to in Chapter 3 (systematics). $\mathrm{T}=$ total length/diameter; $\mathrm{VL}=$ vesicle length; $\mathrm{VW}=$ vesicle width; $\mathrm{V}=$ vesicle diameter; $\mathrm{PL}=$ process length; $\mathrm{P} \Phi \mathrm{b}=$ basal process diameter; $P \Phi=$ process diameter; $P N=$ process number; $M=$ membrane height; $F=$ field width; $\mathrm{FL}=$ flange width; $\mathrm{W}=$ wall thickness; $\mathrm{OH}=$ ornament height. (After Mullins 1996). 


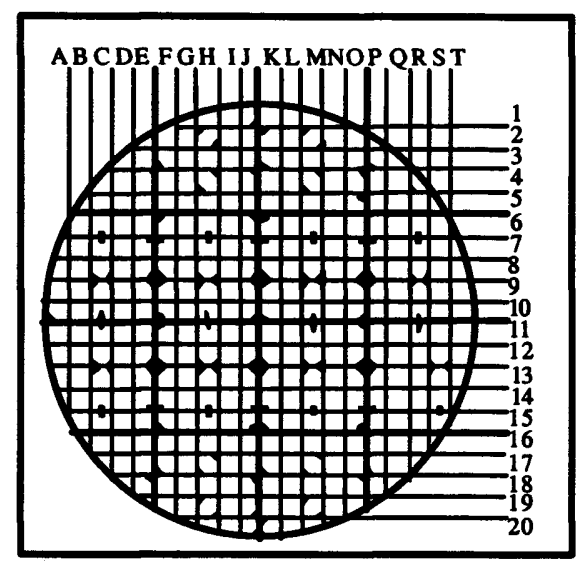

TEXT-FIG. 3.2. Diagram showing the grid and grid reference code used in locating palynomorphs under the SEM.

Synonymy lists

Details of the authors who originally proposed the synonymies that are not explained herein can be found in Fensome et al. (1990). The annotations used in the synonymy list are those of Matthews (1973).

\section{Repository}

Specimens illustrated herein are deposited in the British Geological Survey, Keyworth, Nottingham, UK.

\section{Systematic descriptions}

A list of every species recorded in this study is provided below (illustrations can be found in plates 3-19). A full systematic palaeontology is provided for all new species.

\section{Annotated species list}

\section{PRASINOPHYCEAE Christensen, 1962}

Cymatiosphaera heloderma Cramer and Díez, 1972b. Pl. 3, figs 10-11.

Description of Cramer and Díez (1972, p. 158, pl. 32, fig. 22, pl. 34, fig. 46) used.

Cymatiosphaera aff. ledburica Dorning, 1981. Pl. 3, figs 1-2, 12-13.

Description of Dorning (1981, p. 185, pl. 2, figs. 13-14) used. The specimens illustrated here conform with the written description given by Dorning (1981), but examination of the holotype has revealed a raised circular structure on the vesicle in the centre of each field. The specimens illustrated here are not designated a new species, because in most respects they are identical to the $C$. ledburica holotype. 
Cymatiosphaera octoplana Downie, 1959. Pl. 3, figs 3-5, 9.

Description of Downie (1959, p. 63, pl. 11, figs 4-7, 8-11) used. This species was emended by Mullins (2001) to include $C$. prismatica Deunff, 1954 and thus encompasses specimens such as that illustrated in Pl. 3 fig. 6.

Cymatiosphaera sp. B of Le Hérissé, 1989. Pl. 3, figs 7-8.

Description of Le Hérissé (1989, pp. 77-78, pl. 1, figs 21-24) used. It is considered that too few specimens have been recorded in this study to erect a species name.

Dictyotidium alveolatum (Kiryanov, 1978) Le Hérissé, 1989. P1. 4, figs 1-2.

Description of Le Hérissé (1989, p. 107, pl. 3, figs 1-2, 4-5) used.

Dictyotidium dictyotum (Eisenack, 1938) Eisenack, 1955. P1. 4, figs 4-5.

Description of Eisenack (1938, p. 27-28, pl. 3, figs 8a-c) used. Eisenack (1955, p.179) noted that the original holotype has been lost, but did not designate a neotype. Mullins $(2001, \mathrm{p} .41)$ suggested that the specimen illustrated by Le Hérissé (1989, pl. 3, fig. 12) should be designated as the neotype.

Dictyotidium faviforme Schultz, 1967. Pl. 4, figs 7-8.

Description of Schultz (1967, p. 183, pl. 1, fig. 16) used.

Dictyotidium perlucidum Le Hérissé, 1989. Pl. 4, fig. 6.

Description of Le Hérissé (1989, p. 110, pl. 3, figs 10,11) used.

Dictyotidium stenodictyum Eisenack, 1965. Pl. 4, fig. 10.

Description of Eisenack (1965, pp. 264-265, pl. 2, figs. 2-3) used.

Duvernaysphaera aranaides (Cramer, 1964) Cramer and Díez, 1972b. Pl. 3, figs 14-15. Description of Cramer (1964, pp. 329-330, pl. 14, fig. 7, as Helios) used.

Pterospermella foveolata Dorning, 1981. Pl. 5, figs 1-3.

Description of Dorning (1981, p. 197, pl. 3, fig. 18) used. No comparison between $P$. foveolata and $P$. martinii has been made in the literature. It is considered herein that they are very similar, but $P$. foveolata has a granulate vesicle (as mentioned by Dorning, 1981, p. 197) and $P$. martinii has a smooth vesicle (the holotype needs further investigation to confirm this). 
Pterospermella martinii Cramer, 1966a. Pl. 5, figs 4-6.

Description of Cramer (1966a, p. 250, pl. 1, fig. 9, text-fig. 4, no. 4) used.

Pterospermella marysae Le Hérissé, 1989. Pl. 5, figs 7-8.

Description of Le Hérissé (1989, p. 79, pl. 5, figs. 1-5) used.

Pterospermella saturniforme sp. nov. Pl. 19, figs 8-9, Text-fig. 3.2 G-H.

New species, see full description below.

Quadraditum fantasticum Cramer, 1964b. Pl. 4, figs 11-12.

Description of Cramer (1964b, p. 334, pl. 14, figs. 3-4) used.

Tasmanites Newton, 1875. Pl. 4, fig. 15.

Diagnosis of Newton $(1875$, p. 341$)$ used.

\section{ACRITARCHA Evitt, 1963}

Ammonidium microcladum (Downie, 1963) Lister, 1970. Pl. 4, figs 13-14.

Description of Downie (1963, p. 645, pl. 91, fig. 6, text-fig. 3g, as Baltisphaeridium) used.

Buedingiisphaeridium? globulosum sp. nov. P1. 19, figs 10-11, Text-fig. 3.2 I-J.

New species, see full description below.

Buedingiisphaeridium? aff. globulosum sp. nov. Pl. 19, fig. 11.

A taxon similar to $B$ ? globulosum sp. nov., but with more numerous processes and a slightly larger vesicle $(45 \mu \mathrm{m})$.

Deunffia brevifurcata Hill, 1974. P1. 5, fig. 9.

Description of Hill (1974, p. 16, pl. 1, figs 5-9) used.

Deunffia monospinosa Downie, 1960. P1. 5, fig. 12.

Description of Downie (1960, p. 198, pl. 1, fig. 8) used.

Deunffia ramusculosa Downie, 1960. Pl. 6, figs 1-2.

Description of Downie (1960, p. 199, pl . 1, fig. 2) used. 
Diexallophasis denticulata wolynica Kiryanov, 1978. Pl. 6, fig. 5.

Description of Le Hérissé (1989, p. 128, pl. 12, figs 1-2 as Evittia) used.

Diexallophasis gotlandica Cramer, 1970. Pl. 6, figs 3-4.

Description of Cramer (1970, pp. 138-140, pl. 10, fig. 151 and pl. 20, fig. 302, text-fig 43b) used. The description of $D$. ontariensis Cramer by Cramer (1970, p. 140, pl. 10, figs 152-153, $157-158$, text-fig. $43 \mathrm{c}$ ) is extremely similar to that of $D$. gotlandica; the two species are probably the same and have not been differentiated in this study.

Diexallophasis granulatispinosa (Downie, 1963) Hill, 1974. P1. 6, figs 6-7.

Description of Downie (1963, pp. 640-641, pl. 91, fig. 1,7, as Baltisphaeridium) used.

Diexallophasis remota (Deunff, 1955) Playford, 1977. Pl. 5, figs 10-11.

Description of Playford (1977, p. 19-21) used.

Dilatisphaera laevigata Lister, 1970. Pl. 6, figs 8-10.

Description of Lister (1970, p. 66, pl. 6, figs 10-12, text-figs 18h, 20d) used.

Dilatisphaera williereae (Martin, 1966) Lister, 1970. Pl. 7, figs 1-2.

Description of Martin (1966, p. 389-390, pl. 1. fig. 23, text-figs 33-34) used.

Dilatisphaera quadratica sp. nov. Pl. 19, figs 1-3, Text-fig. 3.2 A-B.

New species, see full description below.

Domasia amphora (Martin, 1969) emend. Hill, 1974. Pl. 7, fig. 3.

Description of Le Hérissé (1989, p. 99, pl. 8, figs 11-13) used.

Domasia bispinosa Downie, 1960. Pl. 7, figs 4.

Description of Downie (1960, p. 200, pl. 1, fig. 3) used.

Domasia quadrispinosa Hill, 1974. Pl. 7, figs 5-6.

Description of Hill (1974, p. 18, pl. 1, figs 12-15) used.

Domasia trispinosa (Downie, 1960) Hill, 1974. Pl. 7, figs 7-8.

Description of Downie (1960, p. 199-200, pl. 1, fig. 7) used 
Eisenackidium ranaemanum Le Hérissé, 1989. P1. 7, fig. 9.

Description of Le Hérissé (1989, p. 120, pl. 9, figs 9-13) used.

Elektoriskos aurora Loeblich, 1970. Pl. 7, figs 11-12.

Description of Loeblich (1970, p. 717-718, fig. 12 A-D) used.

Eupoikilofusa filifera (Downie, 1959) Dorning, 1981 emend. Pl. 7, fig. 13.

Description of Mullins (2001, p. 80, pl. 8, fig. 1; pl. 17, fig. 8) used. The specimen illustrated by Mullins has the same morphology as the specimen Le Hérissé assigned to E. strifiera typica (an invalid name, see Fensome et al. p. 216); see discussion by Mullins (2001).

Eupoikilofusa striatifera Cramer, 1964a. Pl. 8, figs 12-13.

Description of Cramer (1964, p. 35-36, pl. 2, figs 9, 13) used.

Elektoriskos longispinosum sp. nov. Pl. 19, figs 6-7, Text-fig. 3.2 C-D.

New species, see full description below.

Gorgonisphaeridium succinum Lister, 1970. P1. 8, figs 1-2.

Description of Lister (1970 p. 75, pl. 8, figs 1-4) used.

Gracilisphaeridium encantador (Cramer, 1970) ex Eisenack et al., 1973. Pl. 8, figs 3-5.

Description of Cramer (1970, pp. 189-190, pl. 19, figs 196-299, as Baltisphaeridium) used.

Helosphaeridium citrinipeltatum (Cramer and Díez, 1972) Dorning, 1981. Pl. 8, figs 8-9.

Description of Cramer and Díez (1972b, pp. 166-169, pl. 35, figs 58-59, as

Lophosphaeridium) used.

Helosphaeridium clavispinulosum Lister, 1970. P1. 8, figs 6-7.

Description of Lister (1970, p. 76, pl. 8, figs 8, 12, 16) used.

Helosphaeridium pseudodictyum Lister, 1970. P1. 8, figs 10-11.

Description of Lister (1970, pp. 76-77, pl. 8, figs 9-11, 13-14, 17) used.

Hoegklintia corallina (Eisenack, 1959) Dorning, 1981. Pl. 9, fig. 1. 
Description of Eisenack (1959, p. 201, pl. 16, figs 15-16, as Baltisphaeridium corallinum) used.

Hoegklintia digitata (Eisenack, 1938) Dorning, 1981. P1. 9, figs 2-3.

Description of Eisenack (1938 pp. 20-22, pl. 4, figs 3-5, as Hystrichosphaeridium) used.

Hoegklintia visbyensis (Eisenack, 1959) Dorning, 1981. Pl. 9, fig. 4.

Description of Eisenack (1959, pp. 200-201, pl. 16, figs 12-14, as Baltisphaeridium) used.

Leiofusa parvitatis Loeblich, 1970. Pl. 9, figs 5-6.

Description of Le Hérissé (1989, p. 151, pl. 16, fig. 1) used.

Leiofusa cf. banderillae Cramer, 1964b. P1. 9, figs 7-8.

The specimens illustrated here are similar to the holotype, but show a more elongate (yet still inflated) vesicle than the rounded vesicle illustrated by Cramer (1964b, p. 36, figs 4-5, 12). A similar form to that found in this study was illustrated by Le Hérissé (1989, pl. 16 fig. 2).

Leiosphaeridia (Eisenack, 1958b) Downie and Sarjeant, 1963 emend. Turner, 1984. Pl. 10, figs $1-4$.

Description of Turner $(1984$, p. 116) used. In this study the genus was split into four categories: large (>29um) with thick walls, large (>29um) with thin walls, small ( $\leq 29 u \underline{m}$ ) with thick walls, and small ( $\leq 29 u \mathrm{~m})$ with thin walls. These arbitrary splits are not intended to imply that these morphological categories accord with species diagnoses.

Leprotolypa gordonense Cramer, 1963. Pl. 10, fig. 5.

Description of Le Hérissé (1989, p.154, pl 18, fig. 16) used.

Micrhystridium eatonense Downie, 1959. Pl. 10, figs 6-7.

Description of Downie (1959, p. 62, pl. 11, fig. 15) used.

Micrhystridium irevikensis Le Hérissé, 1989. Pl. 10, figs 8-9.

Description of Le Hérissé (1989, p. 157, pl. 18, figs 3-5) used.

Micrhystridium stellatum Deflandre, 1945. Pl. 10, fig. 10.

Description of Deflandre (1945, p. 27, pl. 3, figs 16-19) used. 
Micrhystridium sp. A. Pl. 19, figs 4-5, Text-fig. 3.2 E-F.

New species, see full description below.

Moyeria uticaensis Thusu, 1973. Pl.7, fig. 10.

Description of Thusu (1973, p. 142, pl. 2, figs 18-22) used.

Multiplicisphaeridium arbusculum Dorning, 1981. P1. 10, figs 11-12.

Description of Dorning (1981, p. 194-195, pl. 1, fig. 7) used.

Multiplicisphaeridium cladum (Downie, 1963) Eisenack, 1969. P1. 10, figs 13-14.

Description of Downie (1963, pp. 643-644, pl. 92, fig. 5, Text-fig. 3a, as Baltisphaeridium) used.

Multiplicisphaeridium fisheri (Cramer, 1968) Lister, 1970. Pl. 11, fig. 1.

Description of Cramer (1968a, p. 65, pl. 1, fig. 1, as Baltisphaeridium) used.

Multiplicisphaeridium forquiferum (Cramer and Díez, 1972) Eisenack et al., 1973. Pl. 10, figs 15-16.

Description of Cramer and Díez (1972b, p. 151, pl. 32, fig. 20, as Baltisphaeridium) used.

Multiplicisphaeridium forquillum (Cramer and Díez, 1972b) Eisenack et al., 1973. Pl. 11, figs 4-5.

Description of Cramer and Díez (1972b, p. 152, pl. 32, fig. 15, as Baltisphaeridium) used.

Multiplicisphaeridium minguisi Le Hérissé, 1989. Pl. 11, figs 2-3.

Description of Le Hérissé (1989, p. 161-162, pl. 19, figs 6-8, 16) used.

Multiplicisphaeridium monki Le Hérissé, 1989. Pl. 11, fig. 6.

Description of Le Hérissé (1989, p. 162, pl. 19, figs 9-11) used.

Multiplicisphaeridium neaghae Cramer, 1970 ex Eisenack et al., 1973. Pl. 11, fig. 7.

Description of Cramer (1970, pp. 134, p. 9, figs 139-142, 391) used.

Multiplicisphaeridium osgoodense (Cramer and Díez, 1972) Eisenack et al., 1973. P1. 11, fig. 8.

Description of Cramer and Díez (1972, p. 153, pl. 33, fig. 26, as Baltisphaeridium) used. 
Multiplicisphaeridium rochesterense (Cramer and Díez, 1972) Eisenack et al., 1973. P1. 11, fig. 9.

Description of Cramer and Díez (1972b, p. 157, pl. 34, fig. 45, pl. 35, fig. 60, as Baltisphaeridium) used.

Multiplicisphaeridium variabile (Lister, 1970) Dorning, 1981. Pl. 12, figs 1-2.

Description of Lister (1970, pp. 87-88, pl. 11. figs 4-7, 9-10, as Multiplicisphaeridium arbusculiferum var. variabile) used.

Multiplicisphaeridium cf. variabile (Lister, 1970) Dorning, 1981. Pl. 12, fig. 3.

This taxon, which is similar to $M$. variabile, has fewer branched processes (often up to half are simple) and a more consistent, although still variable, branching pattern.

Onondagella asymmetrica (Deunff, 1954 ex Deunff, 1961) Cramer 1966b, emend. Playford, 1977. Pl. 12, fig. 4.

Description of Le Hérissé (1989, p. 168, pl. 20, figs 3-4.) used.

Oppilatala fermosa (Cramer, 1970) Le Hérissé, 1989. Pl. 12, figs 5-6.

Description of Le Hérissé (1989, p. 171, pl. 23, figs 10-13, Text-fig. 14.8) used.

Oppilatala grahni Le Hérissé, 1989. Pl. 13, fig. 1.

Description of Le Hérissé (1989 p. 172, pl. 23, figs 1-4, Text-fig. 14.6) used.

Oppilatala insolita insolita Cramer and Díez, 1972. Pl. 13, figs 3-4.

Description of Le Hérissé (1989, p. 172-174, pl. 22, figs 7-8, Text-fig. 14.2) used.

Oppilatala insolita compacta Le Hérissé, 1989. Pl. 12, figs 7-8.

Description of Le Hérissé (1989, p. 175-176, pl. 22, figs 9-12, Text-fig. 14.3) used.

Oppilatala juvensis Le Hérissé, 1989. Pl. 13, fig. 2.

Description of Le Hérissé (1989, p. 176, pl. 23, figs 8-9, 15 Text-fig. 14.9) used.

Oppilatala ramusculosa (Deflandre, 1945) Dorning, 1981. Pl. 13, figs 5-6.

Description of Le Hérissé (1989, pp. 177-178, pl. 23, figs 5-7, Text-fig. 14.5) used. 
Oppilatala singularis Le Hérissé, 1989. Pl. 13, fig. 7.

Description of Le Hérissé (1989, p. 178, pl. 24, figs 1-9, Text-fig. 14:11) used.

Polygonium sp. B of Le Hérissé, 1989. Pl. 14, fig. 1.

Description of Le Hérissé (1989, p. 183, pl. 21, figs 12-13) used.

Pulvinosphaeridium pulvinellum Eisenack, 1954. Pl. 14, fig. 2.

Description of Eisenack (1954, p. 210, pl. 1, fig. 10) used.

Salopidium fragelliforme Le Hérissé, 1989. Pl. 14, fig. 3.

Description of Le Hérissé (1989, pp. 189-190, pl. 24, figs 16-17) used.

Salopidium granuliferum (Downie, 1959) Dorning, 1981. Pl. 14, figs 4-5.

Description of Le Hérissé (1989, p. 188, pl. 24, figs 11-13) used.

Salopidium aff. granuliferum (Downie, 1959) Dorning, 1981. P1. 14, figs 8-9.

Description of Le Hérissé (1989, under 'Acritarches anormaux' p. 218, pl. 30 figs 11-12)

used. Some specimens have been observed with extremely expanded bases and reduced process tips.

Salopidium wenlockense (Downie, 1959) Dorning, 1981. P1. 14, figs 6-7.

Description of Le Hérissé (1989, p. 189, pl. 24, fig. 14) used.

Salopidium woolhopense Dorning, 1981. Pl. 14, figs 10-11.

Description of Dorning (1981, p. 198-199, pl. 1, fig. 14) used.

Schismatosphaeridium algerense Cramer and Díez, 1976. Pl. 15, figs 1-2.

Description of Cramer and Díez (1976a, p. 93, although the holotype is illustrated in Cramer and Díez, 1972b, pl. 36, fig. 83) used.

Schismatosphaeridium longhopense Dorning, 1981. Pl. 15, figs 3-4.

Description of Dorning (1981, p. 199, pl. 3. figs 1-2) used.

Schizmatosphaeridium perforatum Staplin et al., 1965. Pl. 15, figs 7-8.

Description of Staplin et al. (1965, p.179, pl. 18, figs. 4-6, 11-12) used. 
Schismatosphaeridium rugulosum Dorning, 1981 emend. Mullins 2001, Pl. 15, figs 5-6.

Description of Mullins (2001, p. 113, pl. 14, fig. 7, 8) used. The specimens illustrated by Le Hérissé (1989, pl. 25 figs 5-6) as $S$. guttulaferum are now $S$. rugulosum, as $S$. guttulaferum is considered a junior synonym.

Tunisphaeridium parvum Deunff and Evitt, 1968. Pl. 15, fig. 9.

Description of Deunff and Evitt (1968, pp. 3-4, pl. 2, figs 15-18) used.

Tunisphaeridium tentaculaferum (Martin, 1967) Cramer, 1970. Pl. 15, figs 10-11.

Description of Martin (1967, p. 312, pl. 1, fig. 23, as Baltisphaeridium) used.

Tylotopalla gaupa (Cramer, 1964b) Eisenack et al., 1973. Pl. 15, figs 13-14.

Description of Le Hérissé (1989, p. 196, pl. 26, figs 1-4) used.

Tylotopalla robustispinosa (Downie, 1959) Eisenack et al., 1973 emend. Pl. 15, fig. 12.

Description of Downie (1959 p. 61, pl. 10, fig. 7, as Baltisphaeridium) used.

Veryhachium checkleyense Dorning, 1981. Pl. 16, fig. 1.

Description of Dorning (1981, p. 200, pl. 1, fig. 10) used.

Veryhachium pertonense Dorning, 1981. P1. 16, figs 2-3.

Description of Dorning (1981, p. 201, pl. 1, fig. 4) used.

Veryhachium rhomboidium (Downie, 1959) Turner, 1984. Pl. 16, fig. 4.

Description of Turner $(1984$, p.145, pl. 11, figs 6, 9) used.

Veryhachium trispinosum (Eisenack, 1938) Stockmans and Willière, 1962a. Pl. 16, figs 5-6.

Description of Eisenack (1938, pp. 14-15, text-figs 2-3, as Hystrichosphaeridium) used.

Veryhachium wenlockium (Downie, 1959) Stockmans and Willière, 1962b. Pl. 16, figs 7-8.

Description of Downie (1959, p. 62, pl. 12, figs 9, 11, as Veryhachium europaeum forma wenlockianum) used.

Visbysphaera brevifurcata (Eisenack, 1954) Lister, 1970. P1. 17, figs 1-2.

Description of Eisenack (1954, pp. 207-208, pl. 1, fig. 2, as Hystrichosphaeridium) used. 
Visbysphaera connexa connexa Le Hérissé, 1989. P1. 17, figs 3-4.

Description of Le Hérissé (1989, pp. 203-204, pl. 27. figs 7-11, text-fig. 18.2) used.

Visbysphaera connexa crispa Le Hérissé, 1989. Pl. 17, figs 5-6.

Description of Le Hérissé (1989, p. 204, pl. 27. figs 12-14, text-fig. 18.3) used.

Visbysphaera connexa hirsuta Le Hérissé, 1989. P1. 17, figs 7-8.

Description of Le Hérissé (1989, p. 204-206, Pl. 27. figs 15-18, text-fig. 18.4) used.

Visbysphaera erratica brevis Le Hérissé, 1989. Pl. 17, figs. 10-11.

Description of Le Hérissé (1989, p. 206, pl. 28. figs 1-4, text-fig. 18.5) used.

Visbysphaera gotlandica Eisenack, 1954. Pl. 17, fig. 9.

Description of Le Hérissé (1989 p. 207-208, pl. 28, figs 6-8, text-fig. 18.6) used as it refers to the dominant form of the processes as being clubbed (rather than funnel-shaped or forkedshaped as Eisenack (1954) suggested).

Visbysphaera meson (Eisenack, 1955) Lister 1970. P1. 17, figs 12-13.

Description of Eisenack (1954, p. 208, pl. 1, figs 3, 9, text-figs 3-4, as

Hystrichosphaeridium) used.

Visbysphaera microspinosa (Eisenack, 1954) Lister, 1970. P1. 18, figs 1-2.

Description of Eisenack (1954, pp. 209-210, pl. 1, fig. 8, as Hystrichosphaeridium) used.

Visbysphaera oligofurcata Eisenack, 1954. Pl. 18, figs 3-4.

Description of Eisenack (1954, p. 208, pl. 1., fig. 4) used.

Visbysphaera pirifera pirifera (Eisenack, 1954) Kiryanov, 1978. Pl. 18, figs 5-7.

Description of Eisenack (1954, p. 206, pl. 1, fig. 1, text-fig. 1, as Hystrichosphaeridium) used.

Visbysphaera pirifera minor Le Hérissé, 1989. P1. 18, figs 8-9.

Description of Le Hérissé (1989, pp. 213-214, pl. 28. figs 12-15, text-fig. 19:10) used.

Visbysphaera cf. gotlandica (Downie, 1959) Dorning, 1981. Pl. 17, fig. 14.

Taxon with larger and more robust processes and larger vesicle than typical $V$. gotlandica. 


\section{Abnormal Acritarchs}

Two unique specimens, (Plate 19, figs 13,14 ), are very rare species probably related to Multiplicisphaeridium cladum. The specimen in fig. 13 possesses a process which has multiple primary branching, very different from the simple bifurcate process seen in the top right of the specimen and too complexly branched to be included within M. cladum. The specimen in fig. 14 shows the terminal branching diagnostic of $M$. cladum, but only on one process, possibly indicating an affinity to Micrhystridium stellatum. These specimens are not dealt with further as only one specimen has been found of each morphotype.

\section{Class PRASINOPHYTA, Christensen, 1962}

\section{Genus PTEROSPERMELLA Eisenack, 1972}

Type species. Pterospermella aureolata (Cookson and Eisenack 1958, p. 49, pl. 9, figs 10-12) Eisenack 1972, p. 597-598, Cretaceous (Cenomanian-Early Turonian).

Diagnosis. (translated by Mullins (2001) from Eisenack 1972, p. 597). "Microfossil in organic substance, in plan view central shell exists, in axial section most are long oval, rarely spherical and in the equatorial are circular, double-walled, with a smooth rimmed or serrated wing. This can be smooth or have radial folds."

Remarks. Eisenack (1972) transferred the species formerly included in Pterospermopsis to Pterospermella, apart from the type species Pterospermopsis danica Wetzel (1952), which is considered to be a damaged chorate dinoflagellate cyst (Morgenroth 1968; Fensome et al.1990, p.249; Colbath and Grenfell, 1995 p. 293).

Pterospermella saturniforme sp. nov.

Plate 19, figs 8-9, Text-fig. 3.2 G-H.

Derivation of name. From the Latin Saturnus (= Saturn) and forma (=shape), in reference to the equatorial membrane present in this taxon. 
Holotype. DG00LK1.56npg1, N34, 4, Plate 19, fig 8, Text-fig. 3.1 g-h, Lower Visby Beds Lusklint 1, Gotland.

Diagnosis. Single and thick-walled, with a spherical to subspherical, granular vesicle. Occasionally the granulation develops into very short processes. The equatorial flange is thin and flexible and smooth to granulate. The short length of the flange is of particlar note. Specimens are usually flattened laterally so that the flange straddles the vesicle and is only observable at the two poles. Excystment opening not observed.

Dimensions. V, 31-33 $\mu \mathrm{m} ; \mathrm{M}, 3-4 \mu \mathrm{m}$ (4 specimens measured).

Remarks. This species of Pterospermella differs from others in the genus as it has a relatively large vesicle and short equatorial flange. The flange is commonly one-tenth of the vesicle diameter. The vesicle diameter is much larger than that seen in $P$. foveolata $(20-25 \mu \mathrm{m})$, the flange much more narrow than in $P$. martini $(15-18 \mu \mathrm{m})$ and $P$. marysae $(5-7 \mu \mathrm{m})$. It occurs very rarely and only four specimens have been identified.

Occurrence. Lower Visby Beds, upper Telychian Stage, Llandovery Series, Locality Lusklint 1, Gotland. Known range: sample DG00LK1.4 to 56.

\section{Group ACRITARCHA Evitt, 1963}

\section{Genus BUEDINGIISPHAERIDIUM Schaarschmidt 1963 emend. Lister 1970 emend. Sarjeant and Stancliffe 1994}

Type species. By original designation, Buedingiisphaeridium permicum Schaarschmidt, 1963, p. 70, pl. 20, figs 4-6, text-fig. 26, from the Upper Permian (Zechstein), Germany.

Diagnosis. (Sarjeant and Stancliffe 1994, p. 24). "Vesicle spherical, of small to moderate size. Eilyma ornamented by numerous low verrucae or conical tubercles, closed at the tip, often thickened or solid, sometimes hollow, or partially so, and with cavities communicating with the vesicle interior. Height of verrucae or tubercles typically less than $2 \mu \mathrm{m}$." 
Remarks. The diagnosis of Staplin et al. 1965 p. 179 is considered by Lister (1970) to be a translation of the original diagnosis of Schaarschmidt 1963. Staplin et al. did not state it was a direct translation and they did not formally state that it was an emendation. Sarjeant and Stancliffe (1994, p. 24), however, emended the genus following the proposals of Staplin et al. (1965, p.179). The comparison between Buedingiisphaeridium and Lophosphaeridium begun by Staplin et al. (1965, p.180) was briefly referred to in Sarjeant and Stancliffe (1994, p. 32) and Mullins (2001, p. 59). Both suggested that the two genera should remain separate until the morphology of the type species of Lophosphaeridium is more clearly understood.

\section{Buedingiisphaeridium? globulosum sp. nov.}

Plate 19, figs 10-11, Text-fig. 3.3 I-J

Derivation of name. From the Latin globus (= ball/globe) in reference to the distinctive globular processes.

Holotype. DG00LK1.24npg1. Plate 19, fig 10, Text-fig. 3.3 I, Lower Visby Beds, Llandovery Series, Lusklint 1 , Gotland.

Diagnosis. Subspherical, thick-walled vesicle; the bases of the processes are often indistinguishable from the vesicle. Processes (7-26) mostly regularly spaced, but occasionally clumped. The processes are very globular to semi-spherical and have no definite point to the process tips. The processes are very stunted, simple, hollow, and occasionally slightly narrower at the base. The vesicle has a granulate surface. Excystment mechanism was not observed.

Dimensions. VW, 16-30 $\mu \mathrm{m}$; VL, 17-34 $\mu \mathrm{m}$; PL, 2-3.5 $\mu \mathrm{m}$, PФb, 2-5-6 $\mu \mathrm{m}$ (6 specimens measured).

Remarks. This species does not conform closely to the diagnosis of Buedingiisphaeridium, as it does not possess 'an ornament of solid tubercles' (Lister 1970 p. 61). The characters of this species are not considered distinctive enough to erect a new genus and is therefore questionably assigned to Buedingiisphaeridium. Buedingiisphaeridium and Psenotopus Tappan and Loeblich, 1979 share a number of common characters, such as a spherical vesicle and small globular ornament. These characters are not considered close enough for this species to be assigned to Psenotopus. 
Occurrence. Lower and Upper Visby beds, Telychian Stage, Llandovery Series and

CHAPTER 3

Sheinwoodian Stage, Wenlock Series, Locality Lusklint 1, Gotland. Known range: sample DG00LK1.28 to 251 .

\section{Genus DILATISPHAERA Lister, 1970}

Type species. By original designation Dilatisphaera laevigata Lister, 1970, p. 66, pl. 6, figs 10-12, text-figs 18, 20d; Upper Elton Formation, Ludlow Series, Ludlow, Shropshire, UK.

Diagnosis. (Lister 1970, p. 65). "Vesicle hollow, double-walled, spherical to subspherical; processes few in number, single-walled, hollow, broad; proximally they are closed to the vesicle cavity, distally they are open. Excystment aperture apical, controlled by obvious suture."

Remarks. Dilatisphaera has many features similar to those seen in dinoflagellates (Lister 1970); including apical excystment aperture, double-walled vesicle and open-ended processes. However, it was not included by Colbath and Grenfell (1995) in the Cymbosphaeridium clade, which was suggested as a possible candidate for Palaeozoic dinoflagellates (Colbath and Grenfell 1995, p. 310).

\section{Dilatisphaera quadratica sp. nov.}

Plate 19, figs 13, Text-fig. 3.3 A-B.

Derivation of name. From the Latin for square (quadratum), after the stunted processes which are often square shaped.

Holotype. DG00LK1.227npg1, U42, Plate 19, fig. 1, Text-fig. 3.3 A, Upper Visby Beds, Wenlock Series, Lusklint 1, Gotland.

Diagnosis. Vesicle single-walled, spherical to subspherical; 3-5 regularly spaced processes, which are translucent and filmy. The unbranched processes are short, often square in shape, unornamented, and distally open. The vesicle is granulate grading to a dense covering of short, or very short, fine hairs or processes. Excystment mechanism was not observed.

Dimensions. V, 13-19 $\mu \mathrm{m} ; \mathrm{PL}, 6-13 \mu \mathrm{m} ; \mathrm{P} \Phi, 6-8 \mu \mathrm{m}$ (10 specimens measured). 
CHAPTER 3

Remarks. This species of Dilatisphaera is very similar to $D$. williereae, but $D$. quadratica has much shorter and often wider processes. The processes commonly have a 1:1 width:height ratio. The processes are often very difficult to discern, unless differential interference contrast is used. Lister described $D$. laevigata as having a smooth vesicle, but when re-examined the holotype clearly has a granulate vesicle. $D$. quadratica differs from $D$. laevigata in having a more prominent ornamentation on the vesicle and shorter processes.

Occurrence. Upper Visby Beds, Sheinwoodian Stage, Wenlock Series, localities Lusklint 1 and Lickershamn 2, Gotland. Known range: samples DG00LK1.38 to 255 and DG00LH2.37 to 5 .

\section{Genus ELEKTORISKOS Loeblich, 1970}

Type species. By original designation, Elektoriskos aurora Loeblich, 1970, p. 717-718, figs 12 A-D; Malpewood Shale, middle Silurian, Genesee River, Rochester, New York.

Diagnosis. (Loeblich 1970, p. 717) "Circular to subcircular vesicle central body, wall apparently single layered, psilate, chagrenate to granulate with numerous slender, flexible but solid processes which do not communicate with the interior of the central body."

Remarks. Elektoriskos is a distinctive genus with a combination of simple, thin, moderately long, wiry processes and a very thin, transparent vesicle. This genus differs from Comasphaeridium Staplin et al., 1965 because the processes have a lower density and are not 'crowded' (as described by Staplin et al. 1965, p. 192) and from Filisphaeridium Staplin et al., 1965 because the processes are much finer and not thickened.

Elektoriskos longispinosa sp. nov.

Plate 19, figs 6-7, Text-fig. 3.3 C-D.

Derivation of name. From the Latin for long and spine (longus and spina) referring to the extended processes length.

Holotype. DG00LK1.171npg1, O42, Plate 19, fig. 6, Text-fig. 3.3 D, Upper Visby Beds, Wenlock Series, Lusklint 1, Gotland. 
Diagnosis. Subspherical, thin-walled, transparent vesicle, with 5-8 regularly spaced processes, which are very fine and wiry. The processes are long, simple, solid, and slightly expanded at the base. The vesicle is smooth to granulate with a slightly wrinkled surface. Excystment mechanism not observed.

Dimensions. V, $19 \mu \mathrm{m}$; PL, 16-22 $\mu \mathrm{m}$; PФb, 1-1.5 $\mu \mathrm{m}$; PФ, 0.5-0.75 $\mu \mathrm{m}$ (2 specimens measured).

Remarks. E. longispinosa has very similar vesicle ornament and dimentions to $E$. aurora, but the former has far fewer and much longer processes. The process length is commonly equivalent to the vesicle diameter. E. longispinosa differs from other species of Elektoriskos in having slightly expanded process bases. E. longispinosa was not assigned to Comasphaeridium as the processes are not as densely crowded as described by Staplin et al. (1965).

Occurrence. Upper Visby Beds, Sheinwoodian Stage, Wenlock Series, Locality Lusklint 1, Gotland. Known range: sample DG00LK1.167 to 171.

Genus MICRHYSTRIDIUM Deflandre, 1937, emend. Sargeant and Stancliffe, 1994

1965 Solisphaeridium Staplin, Jansonius and Peacock 1974 Exilisphaeridium Wicander

Type species. By original designation Micrhystridium inconspicuum Deflandre 1935, p. 233, pl. 9, figs 11-12; Upper Cretaceous, France.

Diagnosis. (Sarjeant and Stancliffe 1994, p. 12). "Acritarchs with a spherical, oval to rounded-subpolygonal vesicle whose outline in optical section is not significantly modified by the bases of the spines. Vesicle size small, generally less than $20 \mu \mathrm{m}$; larger species very rarely range above $27 \mu \mathrm{m}$ in diameter. Eilyma typically single-layered, rarely two-layered. Surface psilate to granulate or with other fine microstructure, but not divided into fields or plates. Arising from the vesicle, generally at right angles to the eilyma, are from 9 to 35 
spines with closed tips, usually simple but rarely clavate. The spines may flare somewhat at their bases. Spines hollow to solid; if hollow their central cavity may or may not communicate with that of the vesicle. A few spines may exhibit distal bifurcations or have small holes in their mid section. The spine length can range from ca. $1.5 \mu \mathrm{m}$ to greater than the vesicle diameter. Release of the vesicle contents occurs by formation of a linear slit or a cresentic to horseshoe-shaped opening (epityche) or by opening of a cryptosuture, causing loss of an irregularly shaped portion of one surface: regularly formed circular polygonal openings (pylomes) are not developed".

Remarks. The diagnosis of Micrhystridium has been emended by many authors (see Sarjeant and Stancliffe 1994) and numerous genera have been considered synonyms (Eisenack $e t$ al. 1979, Sarjeant and Stancliffe 1994). Many of the genera listed by Sarjeant and Stancliffe (1994) do not truly conform to their emended diagnosis of Micrhystridium (see discussion in Mullins 2001, p. 93). Eisenack et al. (1979, p. 381) charted the history of the discussions on Micrhystridium.

\section{Micrhystridium sp. A}

Plate 19, figs 4-5, Text-fig. 3.3 E-F.

Description. Vesicle spherical, but commonly deformed into an elongate form. There are 925 regularly spaced processes, which are solid and translucent. The processes are long and thin, simple and evenly spaced. The vesicle is smooth to microgranulate. Excystment is by lateral split, only seen in a few specimens.

Dimensions. V, 10-18 $\mu \mathrm{m}$; PL, 8-13 $\mu \mathrm{m} ; \mathrm{P} \Phi \mathrm{b}, 0.5 \mu \mathrm{m}$ (10 specimens measured)

Remarks. M. sp. A is distinct from M. stellatum and Salopidium granuliferum because of the translucent processes, and has more robust and transparent processes than Elektoriskos aurora. $M$. sp. A is often very difficult to identify and can be easily confused with a small leiosphere, as the processes are hard to observe unless differential interference contrast is used. 
Occurrence. Lower and Upper Visby beds, Telychian Stage, Llandovery Series and Sheinwoodian Stage, Wenlock Series, Locality Lusklint 1 and Lickershamn 2, Gotland. Known range: samples DG00LK1.68 to 257 and DG00LH2.53 to 13. 

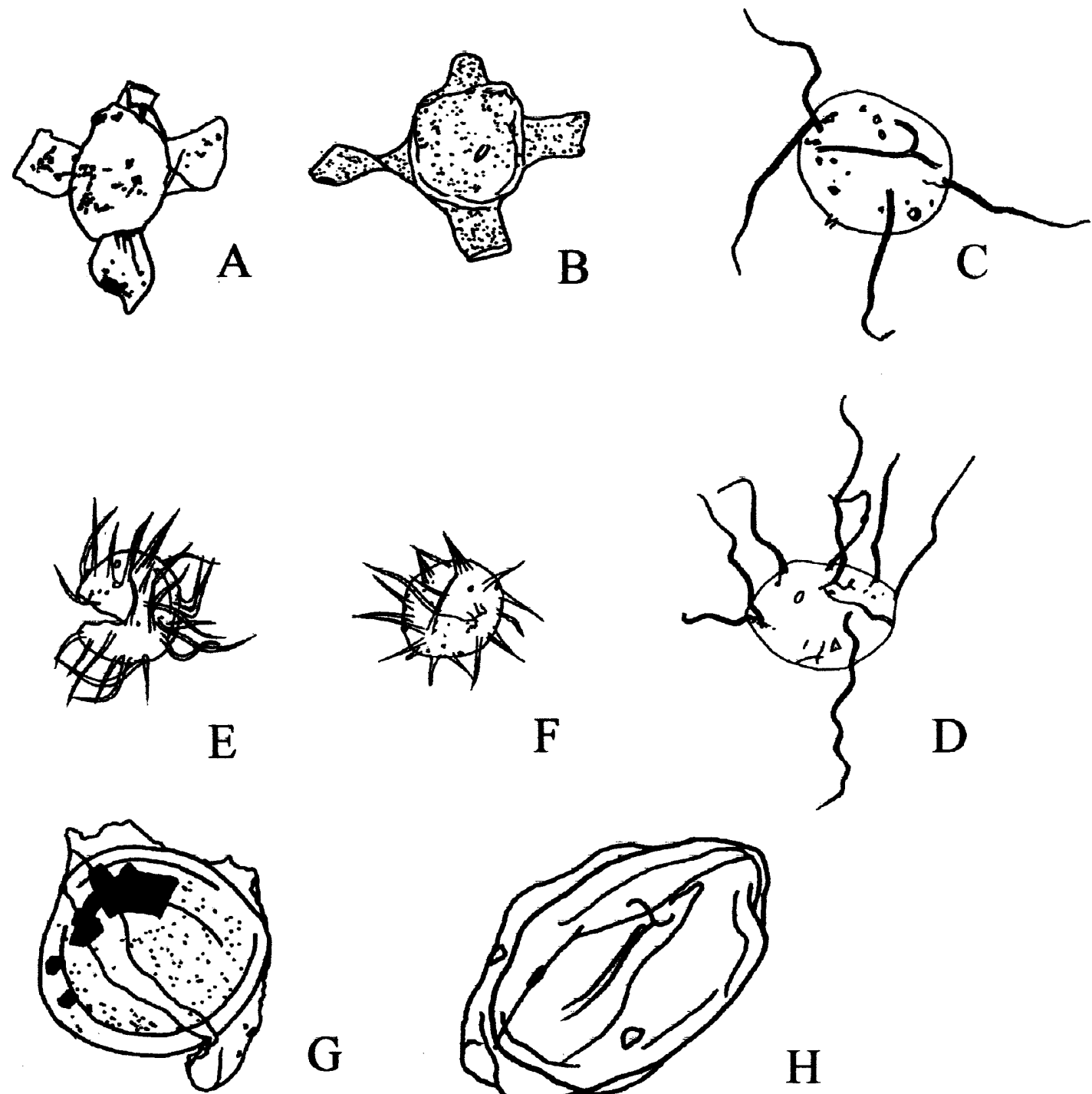

G
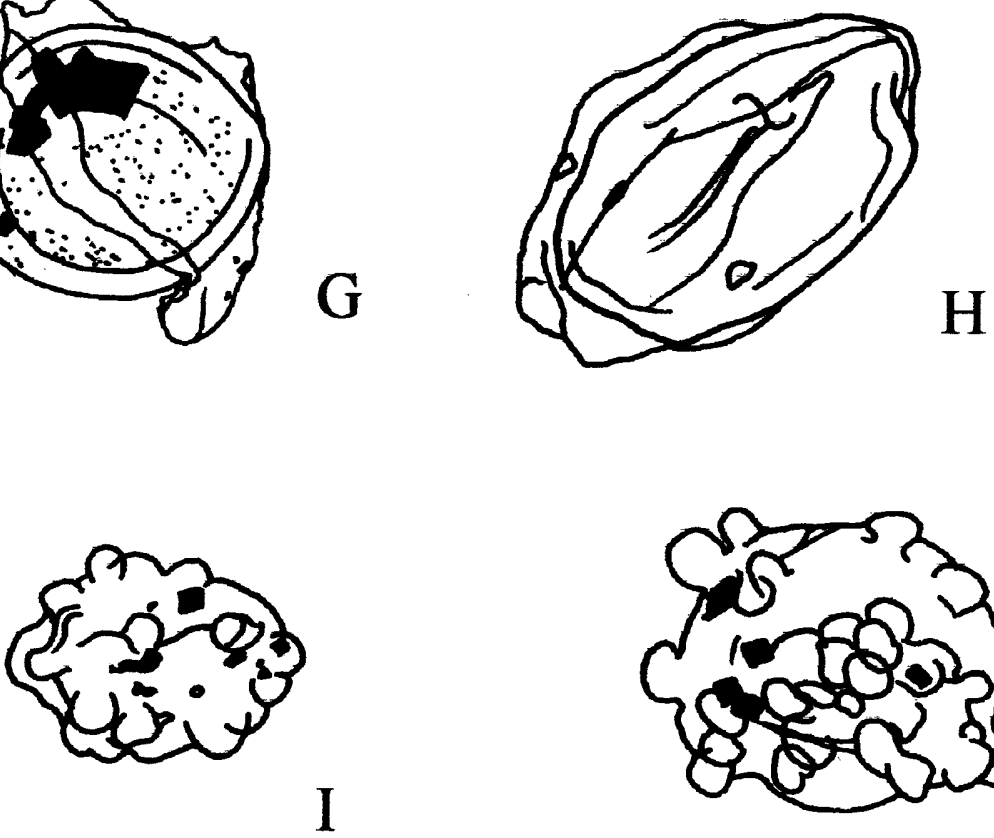

I

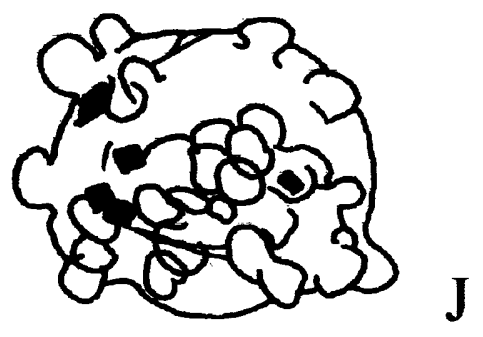

TEXT-FIG. 3.3. Illustration of the variation within the newly diagnosed acritarch species (all x 1000, also see Plate 19). Dilatisphaera quadratica: A, holotype, DG00LK1.227npg1-U42, Upper Visby beds; B, DG00LK1.223npg1-R40, Upper Visby Beds; Elektoriskos longispinosa: C, DG00LK1.167npg1-M43, 3, Upper Visby Beds; D, holotype, DG00LK1.171npg1-O42, Upper Visby beds; Micrhystridium sp.A: E, DG00LH2.17npg1-J32, 1, Upper Visby beds; F,

DG00LK1.112npg1-036, Upper Visby beds; Pterospermella saturniforme: G, holotype, DG00LK1.56npg1-N34, 4, Lower Visby beds; H, DG00LK1.40npg1-M36, 4, Lower Visby beds; Buedingiisphaeridium? globulosum: I, holotype, DG00LK1.183npg1-R38, Upper Visby beds; J, DG00LK1.72npg1-J48, 3, Lower Visby beds. 


\section{RESULTS}

Prior to this study, the palynology of the Lower Silurian of Gotland had not been investigated in detail. The analysis of Gotland palynomorphs conducted by Le Hérissé (1989) was the first real glimpse of the turnover in palynoflora at this time, but only five samples from the Visby Beds were analysed and little quantitative analysis was done. Here, 87 samples have been statistically analysed over the same interval in the Visby Beds.

\section{EXTINCTION, ORIGINATION AND ABUNDANCE CHANGE DATA}

\section{Palynomorph extinction and origination data}

One of the main aims of this study was to analyse the extinction and origination patterns seen in the palynomorphs through the Ireviken Event. To achieve this, stratigraphic range plots have been constructed based on presence/absence data. Many of the species recorded range above and below the section analysed, so have been removed from the plots (see Appendices 1 and 2 for the stratigraphic range plot for the whole data set). To avoid complications arising from possible palynomorph migrations in and out of Gotland at this time, the species ranges have only been extended if this was confirmed by the stratigraphic ranges recorded by Le Hérissé (1989); comparison to other Silurian palynomorph data sets is made later in this chapter. Here, two types of Lazarus taxa have been identified: taxa that suddenly disappear from the record after a relatively common occurrence and then occur at a higher level (such as Schismatiosphaeridium perforatum); or taxa that are less common, but highly distinctive, and disappear from the record, to re-occur at a higher level (such as Visbysphaera pirifera pirifera). The whole data set for both sections, comprising the samples analysed, number of palynomorphs of a species per gram of sediment and percent of that species of the assemblage in a sample, is listed in Appendices 3 and 4.

\section{Palynomorph extinctions}

The dominant pattern shown by the palynomorph species that show range tops in the section at Lusklint 1 is a gradual disappearance, occurring very late in the Ireviken Event (Text-fig. 4.1). $86.3 \%$ of the species that disappear, do so in the top four metres of the section (the rest are spread roughly evenly across the rest of the section). This signal is probably partly due to the close proximity to the top of the section; it may be possible to extend the range of some of the species on analysis of higher samples. The position of the palynomorph last appearances is largely independent of the conodont extinction datum levels. 


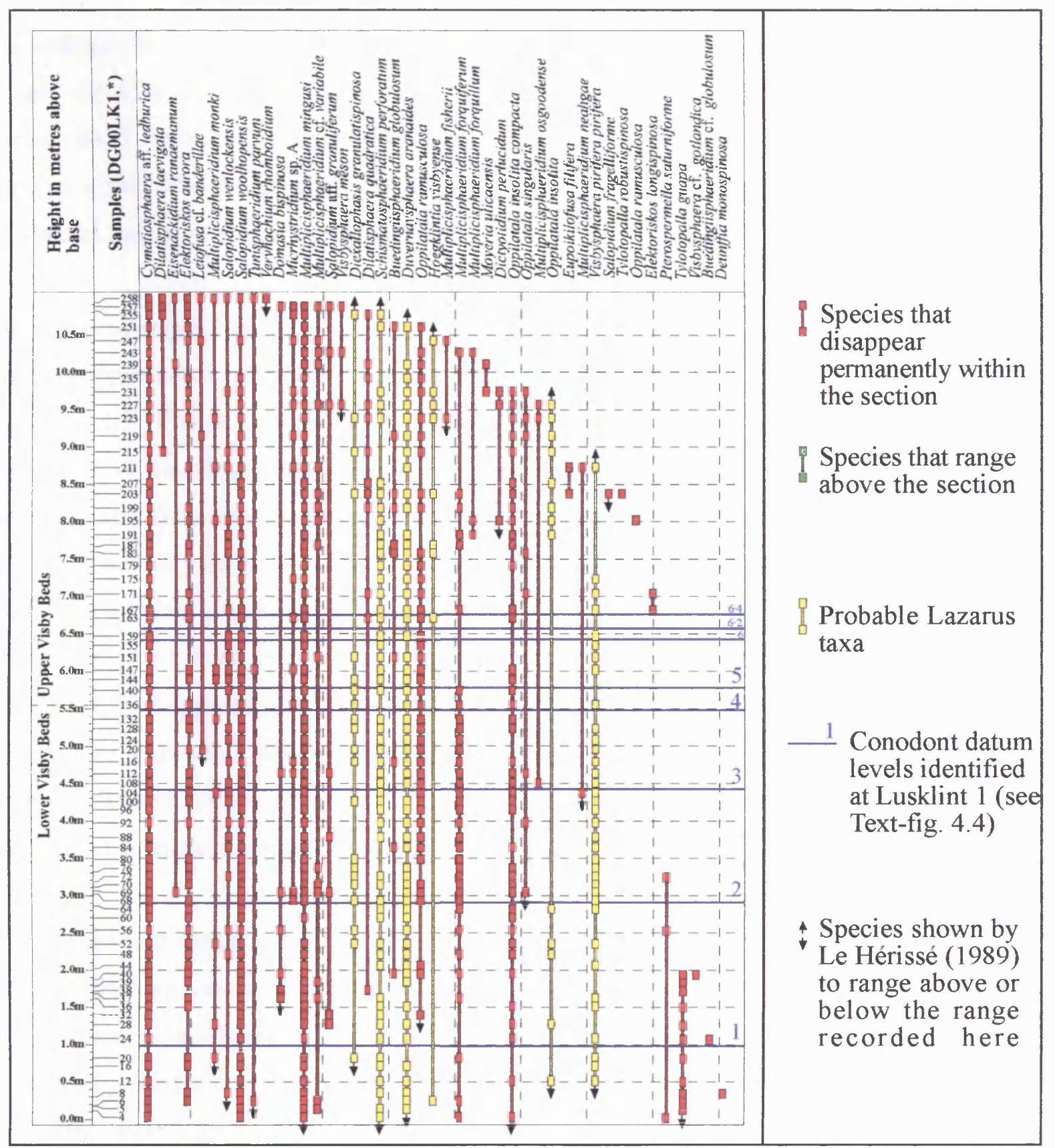

TEXT-FIG. 4.1. Stratigraphic range diagram plotted for Lusklint 1, showing the species that disappear permanently in the section and the probable Lazarus taxa, relative to the conodont extinction datum levels. 


\section{CHAPTER 4}

44 species show range tops in this in the section, 23 of which also show a first appearance here. Eight species were lost from the genus Multiplicisphaeridium, five from the genus Oppilatala, four from Salopidium and three from Visbysphaera. Four genera lost two species and sixteen genera lost one.

The stratigraphic range plot for the species that show range tops at Lickershamn 2 can be seen in Text-fig. 4.2a. Of the 72 species recorded, 22 disappear within the section (including the Lazarus taxa). As at Lusklint 1, Multiplicisphaeridium and Oppilatala are most strongly affected, losing four species each. Three genera lost two species and eight lost one. Two of the species that show range tops in this section also show a first appearance here.

\section{Palynomorph originations}

The first appearances at Lusklint 1 show a different pattern from that of the last appearances (Text-fig. 4.3). Firstly, they are more numerous (54 species first appear in the section as opposed to 44 that show range ends) and secondly, they occur right through the whole of the Ireviken Event. There is an uneven distribution across the event, with a slightly convex pattern seen. This pattern is partly due to a number of species that seem to first appear at the base of the section; at least some of these ranges would probably be extended if lower strata were investigated. Even when this is considered, there is a definite drop in the number of species that first appear in the upper parts of the section, from 42 first appearances below $3.5 \mathrm{~m}$ and 13 above. It is difficult to identify any relationship in the first appearances to the conodont extinction steps, but it could be argued that the number of originations reduces when the main steps in the conodont extinction begin.

Five species first appear from each of the genera Multiplicisphaeridium and Visbysphaera, four from Pterospermella, and three each from Cymatiosphaera, Dictyotidium, Diexallophasis, Dilatisphaera, Eupiokliofusa and Oppilatala. Four genera gained two species and fifteen gained one. Of the 54 species that first appear, 26 have range tops in the section (including Lazarus taxa).

Of the 72 species recorded at Lickershamn 2 (Text-fig. 4.2b), seven show first appearances in the section. Two species from the genus Hoegklintia show first appearances. The other five genera gain one species in this section. 


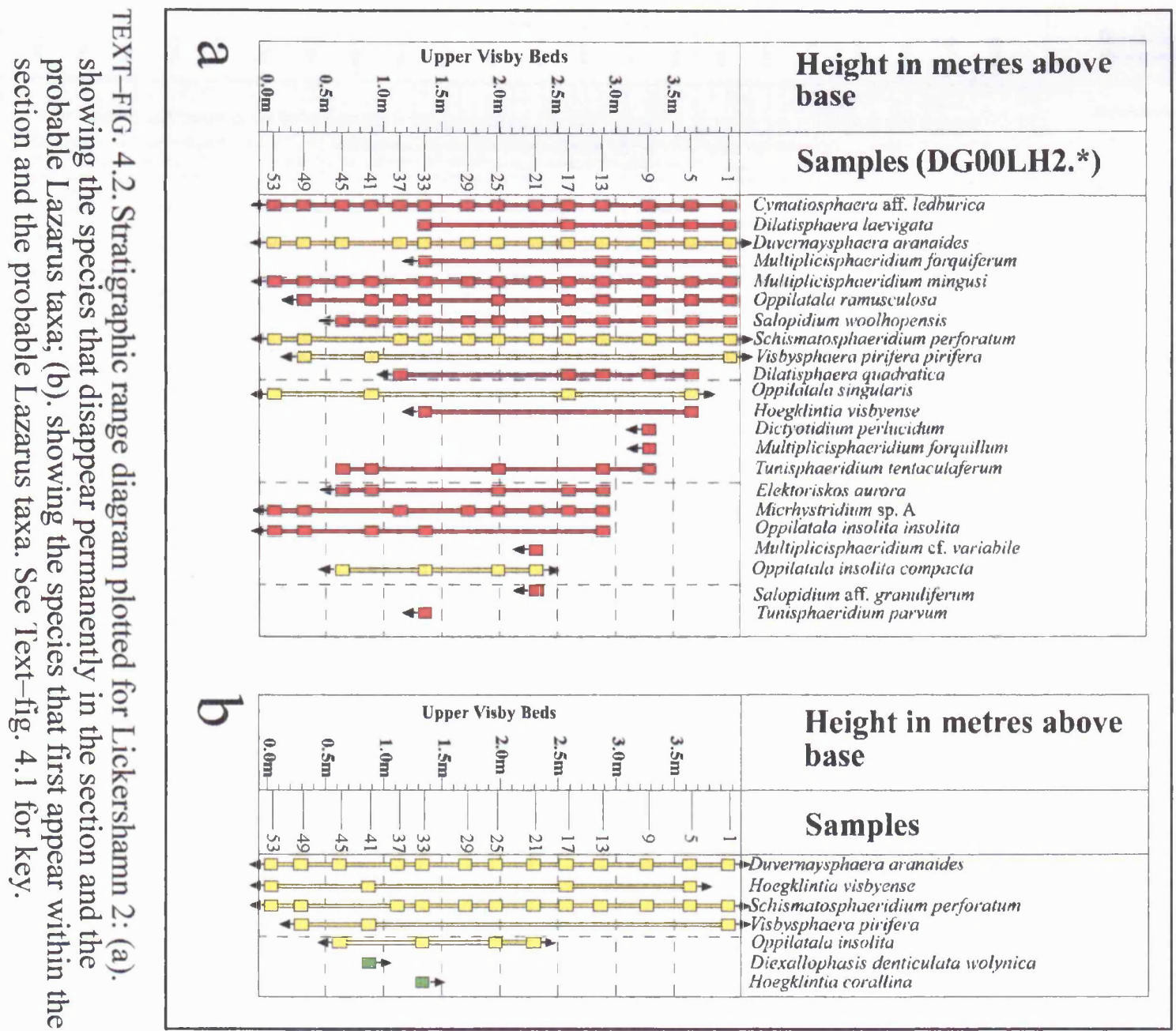




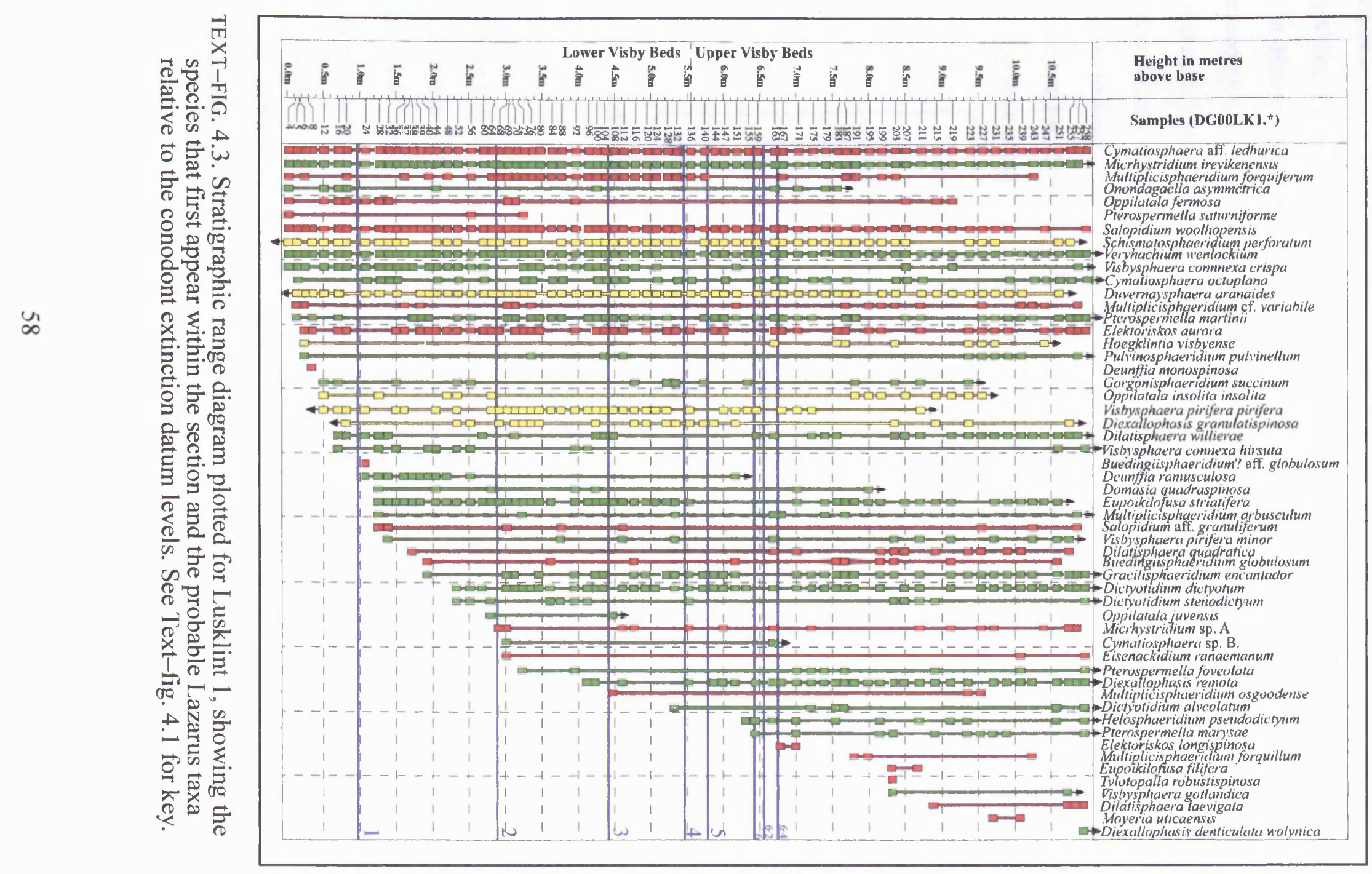




\section{Range end confidence limits}

Local stratigraphic ranges of species are likely to underestimate the true extent of the range. Therefore, a number of quantitative methods for estimating the likely true range ends have been developed. All these methods (commonly used ones are outlined in Marshall 1998, p. 23-53) rely on the recorded stratigraphic range (usually several hundred metres) and the distribution of samples containing, or not containing, the particular species with that range. They do not take into account the gradual or sudden nature of the range end, which is very important in determining confidence limits. For example, if a species were present in ten equally spaced samples in the lowermost ten metres of a twelve metre section, under the conventional calculations the range end would be given a high confidence compared to a species that occurred in fewer than ten samples within the same range. If this species had a gradual decline in numbers to the end of its range (Text-fig. 4.4), it is likely that specimens that define the real range end have been missed in a higher horizon (such as horizon eleven or twelve). This gives a deceptively high level of confidence.

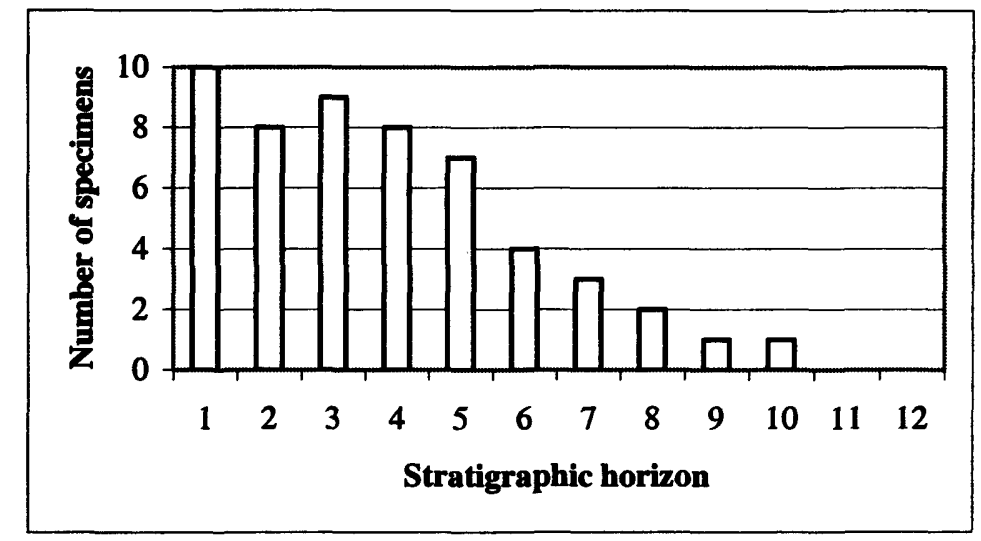

TEXT-FIG. 4.4. Graph showing a species that occurs in every sample within its range, but has a gradual decline in numbers.

Equally, a range end that has very sharp decline in numbers should be regarded with greater confidence than one with a gradual decline. For example, in Text-fig. 4.5, the conventional calculations would regard the last appearance level of this species as having a lower confidence limit than that seen in Text-fig. 4.4, as it does not occur in every sample within its range. However, the sudden disappearance of this previously abundant species means that it is unlikely that it has been missed in horizon eleven. The recorded range end can therefore be considered as having a higher range end confidence level. 


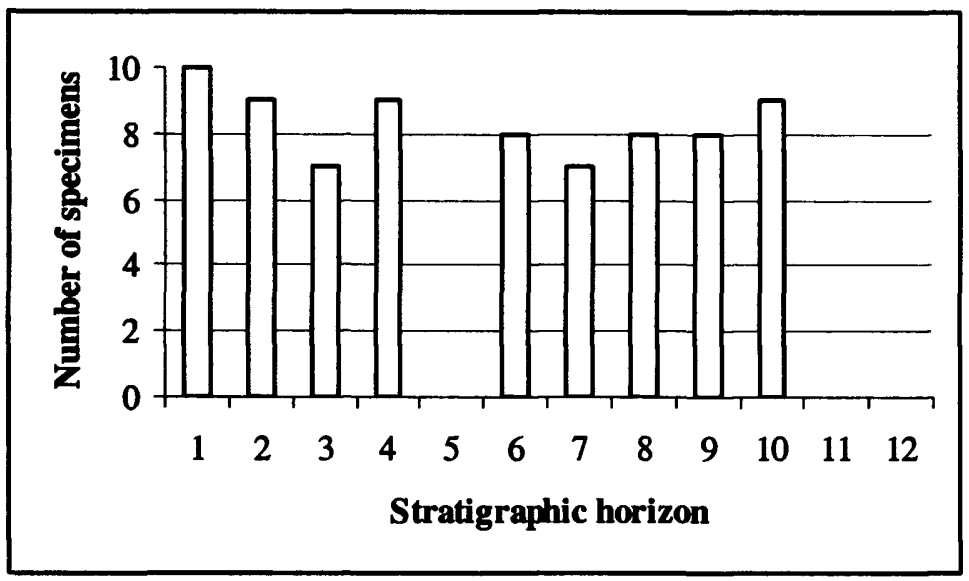

TEXT-FIG. 4.5. Graph showing a species that does not occur in every sample within its range, but is abundant in most of the section and has a sudden decline in numbers.

The Lusklint 1 and Lickershamn 2 datasets are rather different from those normally used in range end calculations. The data collected on Gotland is from a very restricted stratigraphic interval and presence/absence data have been collected in conjunction with highly detailed abundance data. The calculations outlined in Marshall (1998) were applied to the data collected in Gotland (see example in Text-fig. 4.6). The calculations proved inconclusive, often giving calculated extensions range ends that were greater than the entire recorded species range.

\begin{tabular}{|l|c|l|c|}
\hline Species & Height extended $(\mathrm{m})$ & Species & Height extended $(\mathrm{m})$ \\
\hline C. aff. ledburica & 4.50 & H. visbyense & 7.20 \\
\hline D. laevigata & 3.82 & D. perlucidum & 0.00 \\
\hline D. aranaides & 4.55 & M. forquillum & 0.00 \\
\hline M. forquiferum & 3.82 & T. tentaculaferum & 4.12 \\
\hline M. minguisi & 4.55 & E. aurora & 3.45 \\
\hline O. ramusculosa & 4.46 & M. sp. A & 3.73 \\
\hline S. woolhopensis & 3.90 & O. insolita insolita & 4.35 \\
\hline S. perforatum & 4.61 & M. cf. variabile & 0.00 \\
\hline V. pirifera pirifera & 6.60 & O. insolita compacta & 2.25 \\
\hline D. quadratica & 3.90 & S. aff. granuliferum & 0.00 \\
\hline O. singularis & 4.62 & T. parvum & 0.00 \\
\hline
\end{tabular}

TEXT-FIG. 4.6. Table showing the calculated distance the range ends of the species at Lickeshamn 2 should be extended, according to point estimates of the true stratigraphic range ends (see Marshall 1998, p. 24).

A more complex method has been developed to try and address some of the problems encountered above (see discussion in Hayek and Bura 2001). As yet, it has not been established if this method will be fruitful here and this is identified as a line of future work. 


\section{The fraction below $7 \mu m$ in size}

To test for missed species occurrences and range ends, the fraction below $7 \mu \mathrm{m}$ in size was monitored through the whole of both the sections (as outlined in Chapter 2). One in four of the samples processed were analysed. The number of specimens recorded was minimal, never reaching more than 0.8 specimens per gram of sediment; three of the twenty-two samples investigated had no specimens in this fraction. The palynomorphs recovered were dominated by small leiospheres (at $62 \%$ of all the specimens recovered from all the samples). Most of the other palynomorphs were specimens of Domasia trispinosa and Veryhachium wenlockium, which due to their pointed form are more likely than the stellate forms to slip through the $7 \mu \mathrm{m}$ sieve mesh. The topmost samples analysed generally contain several more specimens and species than the lower samples (e.g. sample DG00LK1.257 contained 33 specimens from six species and DG00LK1.48 contained three specimens from two species).

\section{The conodont extinction pattern}

There is a pronounced step-wise extinction pattern seen in the conodonts through the Ireviken Event (Text-fig. 4.7) (Aldridge et al. 1993, Jeppsson 1997). The importance of this data set lies in the large turnover and its high resolution (samples were collected at around ten centimetre intervals, about half the resolution of sampling in this study). The extinction pattern is recognised as a worldwide event (Jeppsson 1997).

\section{The palynomorph abundance data}

The subtle changes in abundance recorded in this study tell a very complex story. To determine any pattern in these data they have been analysed qualitatively and quantitatively through multivariate analysis. The absolute and relative frequency data for taxa in the sections at Lusklint 1 and Lickershamn 2 are listed in Appendices 3-8.

\section{General trends seen at Lusklint 1}

The majority of the species that make up the assemblage recorded at Lusklint 1 maintain a consistent percentage of the whole assemblage through the section. For example Diexallophasis gotlandica has a percent abundance record with a standard deviation of $2.4 \%$, Micrhystridium eatonensis $0.6 \%$ and Veryhachium wenlockium $8.4 \%$. Major changes in the absolute abundance data are not accompanied by changes in the relative proportions (for example the high number of palynomorphs per gram of sediment in sample DG00LK1.187 causes a marked peak in the absolute abundance data, whilst the percentage abundance data change little). Most of the species recorded are rare and occur at fewer than ten per thousand 


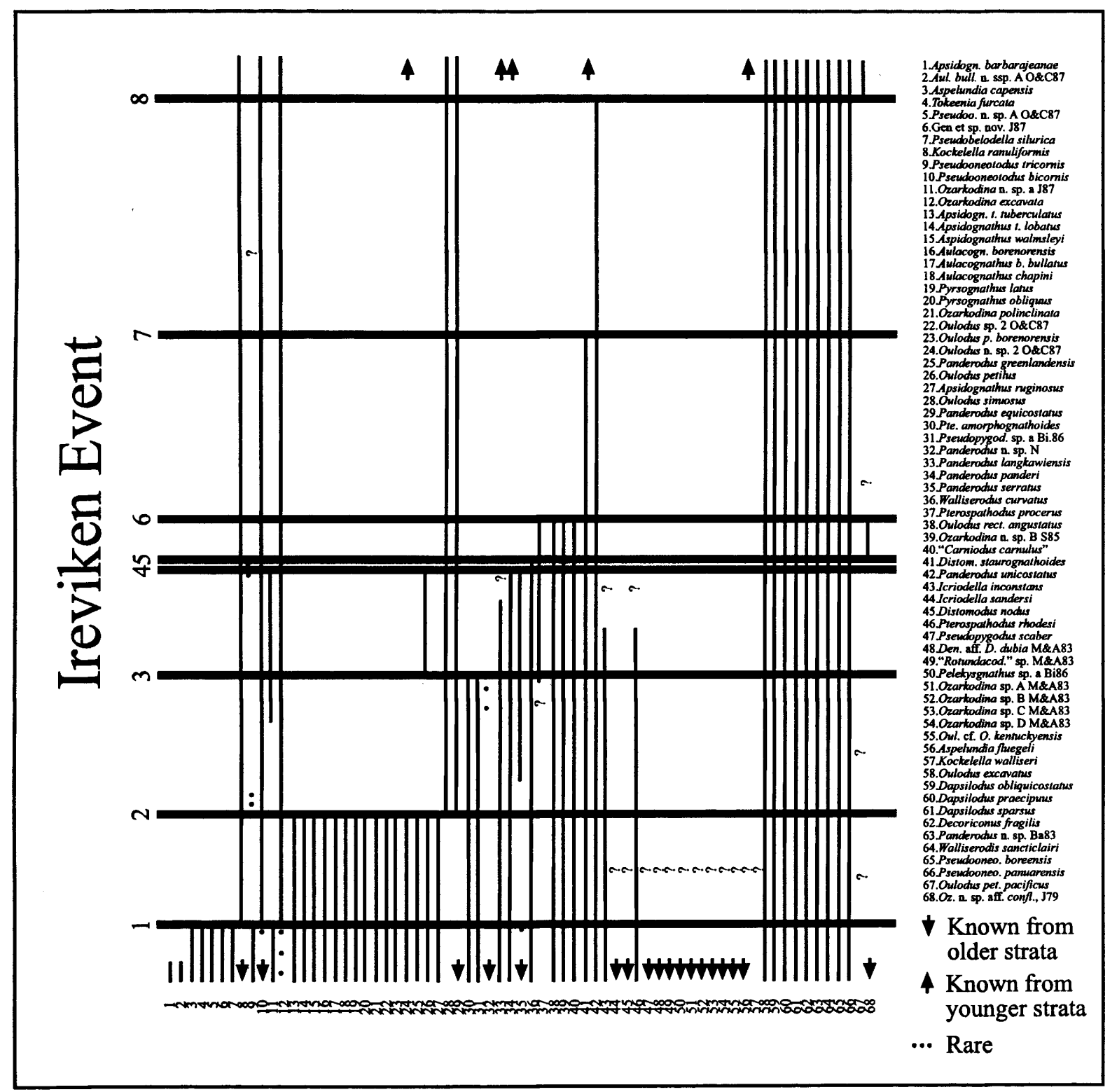

TEXT-FIG. 4.7. Stratigraphic range diagram for the conodonts through the Ireviken Event, adapted from Jeppsson (1997, fig. 17.2). This diagram represents a composite of the conodont data from several sections, not all from Gotland. The extinction datum levels are numbered. The precise datum levels identified at Lusklint 1 are marked on Text-figs 4.1 and 4.3. 
logged. The palynomorph assemblage at Lusklint 1 is dominated by $M$. stellatum, $S$. granuliferum, $V$. wenlockium, D. trispinosa and leiospheres to varying degrees.

In some species the contrasts in abundance between the top, middle and base of the section are marked. This is particularly seen in Micrhystridium stellatum, Salopidium granuliferum and Veryhachium wenlockium. $M$. stellatum has a high level of abundance in the lowermost and uppermost samples (Appendix 6), with a peak of 49.07\% in DG00LK1.8 and a peak of $31.75 \%$ in sample DG00LK1.243. The samples collected in the middle part of the section show consistently low relative numbers of $M$. stellatum (especially between samples DG00LK1. 112 and 159 which are all below 5.5\%).

Salopidium granuliferum is recorded at a plateau of around $22 \%$ in the lowermost samples. In contrast to $M$. stellatum, the relative numbers then fall to a level consistently below $10 \%$ above sample DG00LK1.183.

$V$. wenlockium has a similar pattern to that of $M$. stellatum, but not as pronounced. From the base of the section until sample DG00LK1.28 the relative frequancy of $V$. wenlockium is never higher than $10 \%$. Between samples DG00LK1.32 and 88 a peak is recorded at around $20 \%$. Above this, the percentage abundance varies around 10-15\%, until the uppermost part of the section where a plateau of around $30 \%$ is reached between samples DG00LK1.211 and 235.

The top of the section contains higher levels of Cymatiosphaera aff. ledburica and Veryhachium trispinosum. $C$. aff. ledburica maintains a near constant $1-2 \%$ relative frequency in most of the section sharply rising to a peak of $12 \%$ in DG00LK1.257. $\mathrm{V}$. trispinosum has a slightly more gradual rise over six samples, from $1 \%$ or less, (or often not recorded) to a peak of $9 \%$ in DG00LK1.258. The leiospheres have a generally slightly higher abundance in the Upper Visby Beds at around 10\% in each of the four categories (around 5\% in each category is recorded in the Lower Visby Beds).

A number of species occur in nearly every sample, but only in very low numbers (usually only two or three specimens). For example, Duvernaysphaera aranaides and Pterospermella martini occur through most of the section, but at never more than $1 \%$ of the total assemblage.

More subtle morphological variations were also observed. In samples DG00LK1.112, 116 and 128 (P1.18, fig.7) the Visbysphaera pirifera pirifera specimens have markedly longer 
processes than those from the base and top of the section (Pl. 18, fig. 6). In sample

DG00LK1.144 (PI.3, fig. 15) D. aranaides has wider process bases.

It is difficult to find patterns in much of the abundance data, with many species (e.g. Multiplicisphaeridium minguisi) having an apparently random distribution pattern.

\section{General trends seen at Lickershamn 2}

General trends in the abundance of species at Lickershamn 2 are particularly hard to discern, mainly because of the short height of the section. As at Lusklint 1 , all the samples are dominated by a combination of leiospheres, $M$. stellatum, $V$. wenlockium, S. granuliferum and D. trispinosa, which vary little in relative abundance through the section. Again, most of the species recorded are very low in number, but occur consistently.

\section{Multivariate analysis}

To investigate patterns in the data, correspondence analysis and cluster analysis were undertaken. To avoid unnecessary spread in the plots, outliers (species that occur in less than five percent of the samples and samples that contain less than five percent of the species) were removed from the dataset (see discussion in Shi 1993, p. 204). The data were also transformed to a logarithmic scale to minimise the tendency of all the most abundant species to cluster together.

The transformed dataset was investigated using correspondence analysis and cluster analysis. Correspondence analysis is an ordination technique, but unlike other methods assigns differential weights to samples, thereby maximising the correlation between samples or taxa. Plots of the spatial relationship in three-dimensions between samples or taxa are produced, grouping together similar samples (see discussion in Shi 1993, p. 221). There are a number of cluster analysis methods, which emphasise different aspects of similarity and dissimilarity within a dataset (see discussion in Etter 1999, p. 305-311). Here, Morisita's index is used because it is recommended by Etter (1999) as the best overall measure of similarity.

The correspondence analysis for the samples at Lusklint 1 (Text-fig. 4.8) shows that most of the samples cluster in one group around 0 , with relatively small variance. A number of outliers (sample numbers shown) are located slightly away from the main group. No discrete groups can be distinguished from these plots. 


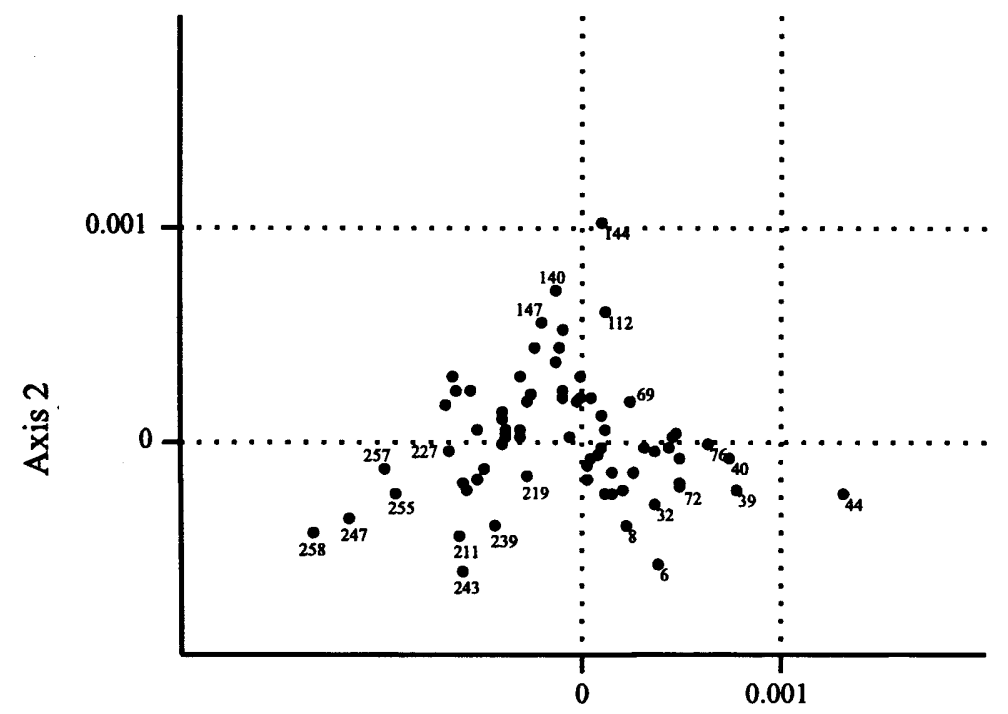

Axis 1

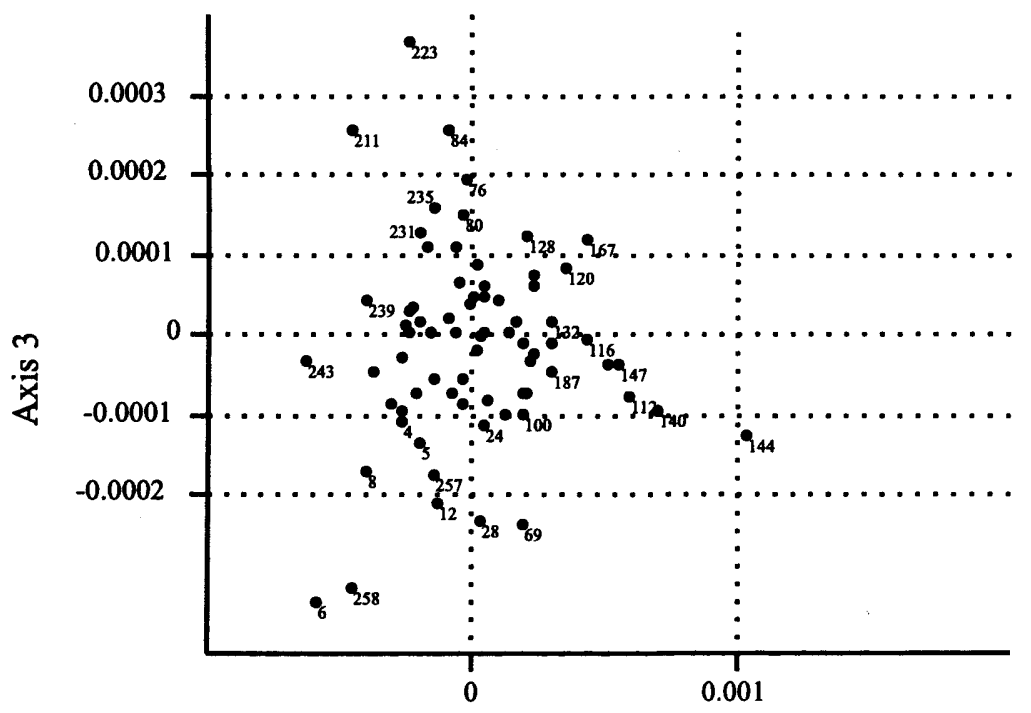

Axis 2

TEXT-FIG.4.8.Plots showing the three-dimensional distribution of the samples at Lusklint 1 after correspondence analysis (numbers refer to the sample e.g. DG00LK1.1, the numbers for the tightly clustered samples on the plot have been removed for clarity). 
Using the Morisita cluster analysis method (Text-fig. 4.9) six distinct groups of samples at Lusklint 1 are identified (defined by the colours and letters). When plotted against the samples in stratigraphic order (Text-fig. 4.10) the groupings are less clear, but three broader groups can be identified: a lower group (below sample LK1.92) characterised by some of the samples from group $\mathrm{E}$ and group $\mathrm{B}$ and most of the samples from group $\mathrm{F}$, a middle group (samples LK1.92-215) characterised by samples from group C, group D and group A and a upper group (above sample LK1.215) mostly made up of the remaining group E and group B samples. These groups are remarkably similar to those observed in the general trends section above (picked out by species such as M.stellatum, S. granuliferum and V. wenlockium). This method can potentially pick out repetitions of samples with similar characteristics reflecting otherwise hidden cyclicity and this seems to be the case here. Both the bottom and the top of the section are dominated by samples from groups B and E, though the restricted height of the section means the full extent of a potential cycle is not seen.

The correspondence analysis for the species at Lusklint 1 (Text-fig. 4.11) shows they mostly cluster in one group around zero, with relatively small variance. A number of outliers (species names shown) are located away from the main group; all but two of these outliers ( $D$. granulatispinosa, from the $\mathrm{F}$ cluster and $H$. pseudodictyum, from the $\mathrm{G}$ cluster) lie within the D cluster identified on Text-fig. 4.12 through cluster analysis.

Cluster analysis (Text-fig. 4.12) identifies seven groups of species with similar distributions at Lusklint 1. The major factors associating the species into groups relate to the part of the section where species co-occur in similar numbers and to how commonly the species occur through the whole section. Using Text-fig. 4.11 and 4.12 together, it can be suggested that most of the species occur in the same relative numbers in all samples, apart from the most numerous species (many of which plot as outliers in Text-fig. 4.11, and within group D in Text-fig. 4.12), which have a more variable distribution.

The smaller dataset collected for Lickershamn 2 was treated in exactly the same way as the Lusklint 1 data and the results from correspondence analysis and Morisita cluster analysis plotted.

The correspondence analysis for the samples at Lickershamn 2 (Text-fig. 4.13) shows a much more widely spaced distribution than that seen at Lusklint 1 (Text-fig. 4.8). There is no central cluster of very similar samples and when the clusters groups identified from the cluster analysis dendrogram (Text-fig. 4.14) are added, four distinct groups (A to D) are identified. 


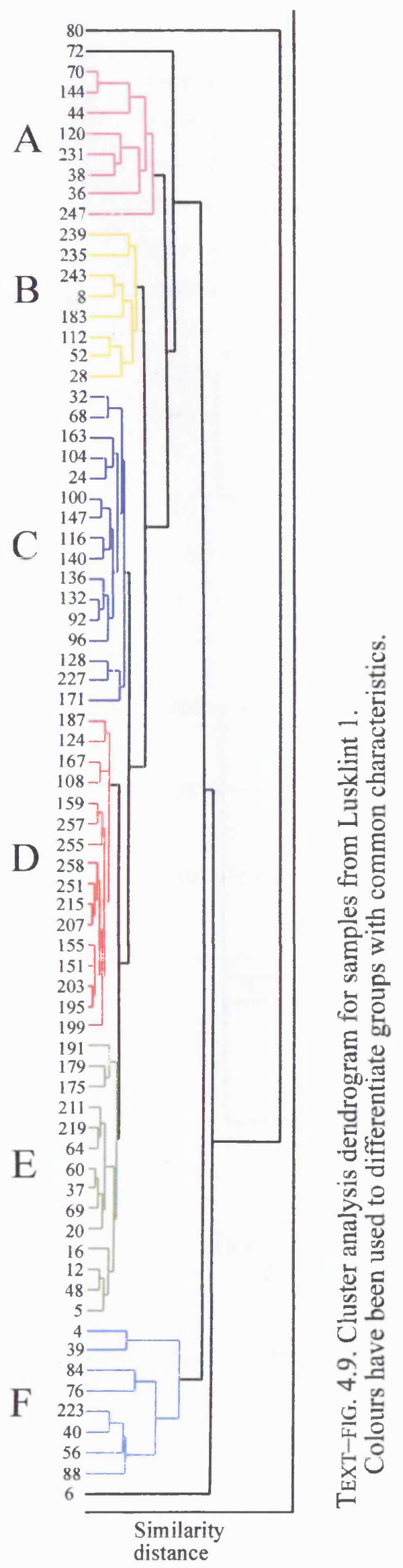

$\begin{array}{ll}\text { LK1.258 } & \text { TEXT-FIG. 4.10. Table showing } \\ \text { LK1.257 } & \text { The cluster analysis groups } \\ \text { LK1.255 } & \text { the cla } \\ \text { LK1.247 } & \text { identified on text-fig. } 4.9 \\ \text { LK1.243 } & \text { relative to the Lusklint } 1 \\ \text { LK1.239 } & \text { LK1.235 } \\ \text { LK1.231 } & \text { samples in stratigraphic order. }\end{array}$

LK1.227 圆

LK1.223

LK1.219믐

LK1.215 워

LK1.211

LK1.207 国

LK1.203 즐

LK1.199 욜

LK1.195톨

LK1.191 日

LK1.187 묘

LK1.183ם

LK1.179 ⿷匚

LK1.175 뭄

LK1.171 묠

LK1.167믐

LK1.163믐

LK1.159

LK1.155 울

LK1.15! 瞩

LKI.147믐

LK1.144 $\square$

LK1.140 ㅁ

I.K1.136

LK1.132 ㅁ

LK1.128믐

LK1.124물

LK1.120 밈

LK1.116뭄

LK1.112

LK1.108뭄

LK1.104뭄

LK1.100 믐

LK1.96 뭄

LK1.92 ㅁ

LK1.88 ㅁ

LK1.84 든

LK1.84

LK1.76

LK1.72

LK1.70

LK1.69 무

LK1.68 뭄

LK1.64 $\square$

LK1.60 ㅁ

LK1.56

LK1.52 口

LK1.48

LK1.48 $\square$

LK1.44

LK1.40

LK1.39 믐

LK1.38

LK1.37

LK1.37

LK1.36

LK1.32

LK1.20 ㅁ

LK1.16믐

LK1.12 ㅁ

LK1.8

LK1.6

K1.5

LK1.5 $\square$
LK1.4 

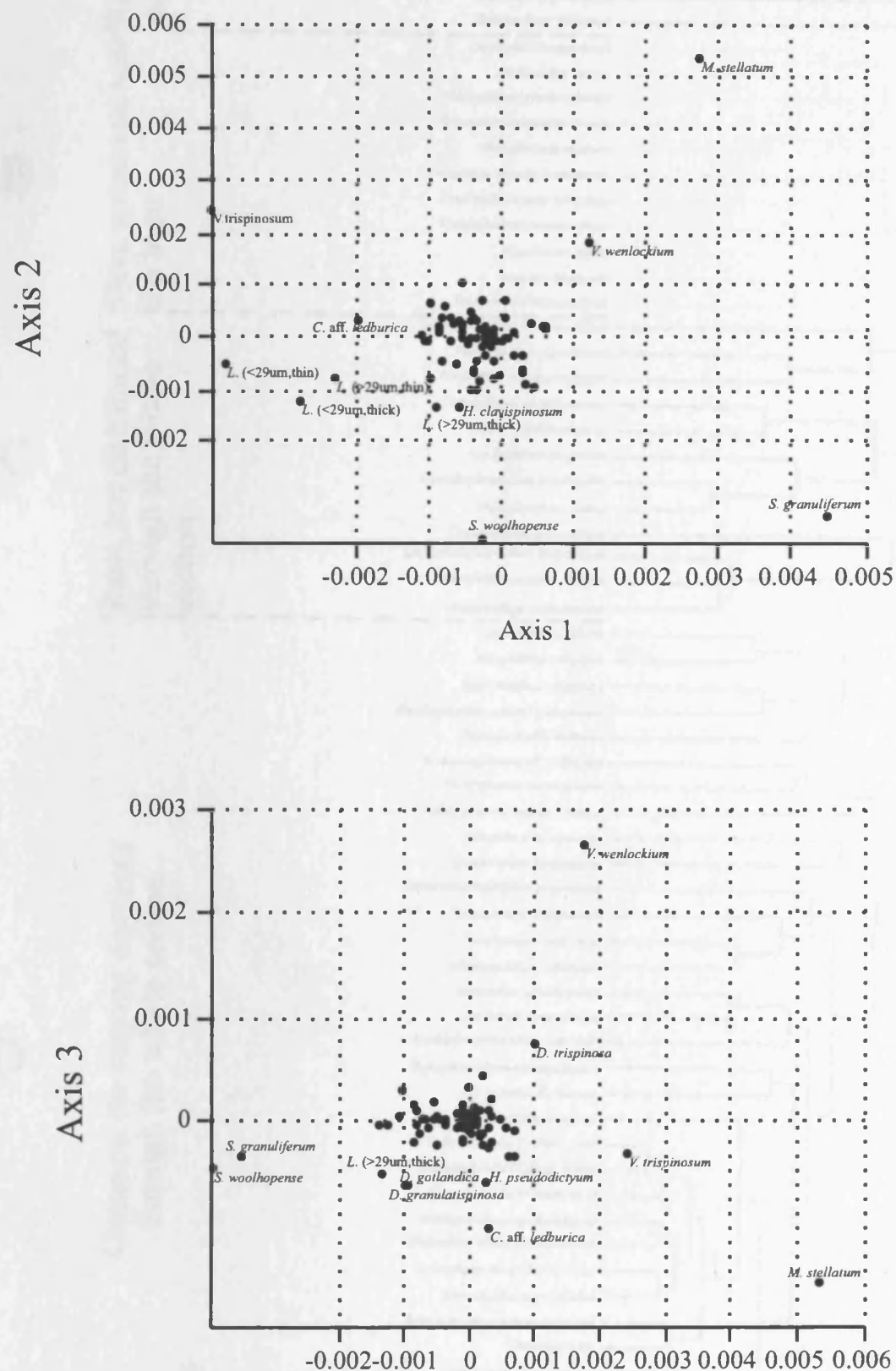

Axis 2

TEXT-FIG.4.11. Plots showing the three-dimensional distribution of the species at Lusklint 1 after correspondence analysis (the species names for the tightly clustered samples on the plot have been removed for clarity). 
Q T] [T

Rare, IRare, morel Rare, but I

variable |numerous |distributed

distribution $\left.\right|^{\text {near the }}$ Ithrough

top lthe whole ।

I Isection

8
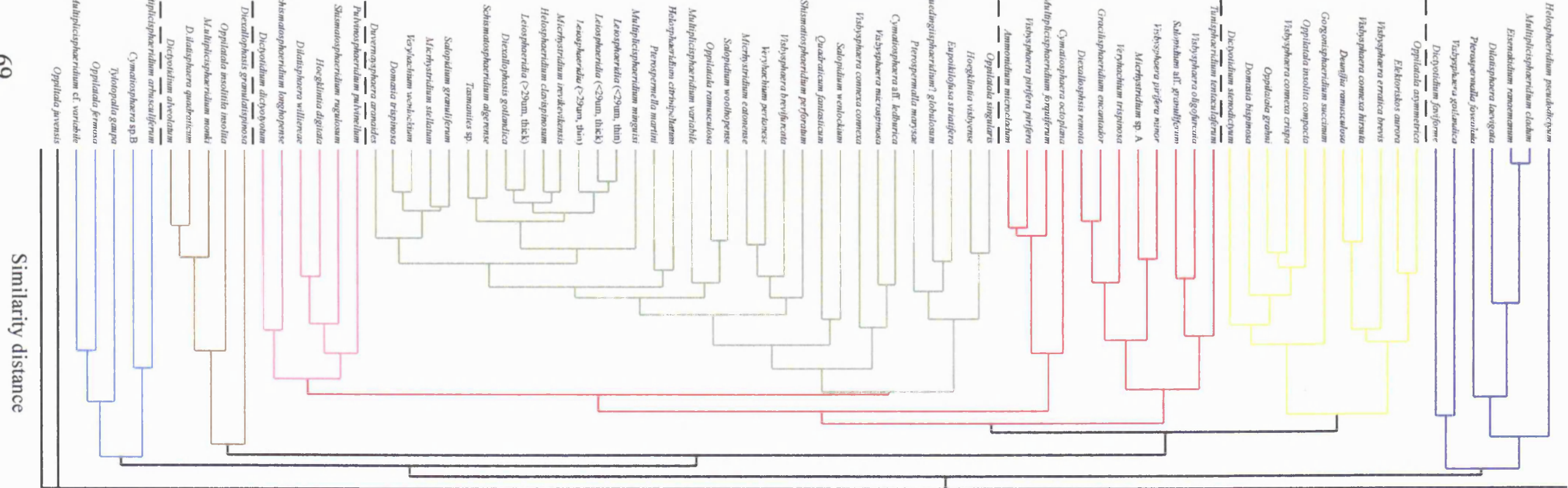

TEXT-FIG. 4.12. Cluster analysis dendrogram for species from Lusklint 1.

Colours have been used to differentiate the clusters with common characteristics.
Common (to varying degrees) through the whole section

IRare, but distributed IMore numerous nearlRare, variable Ithrough the whole lthe base

Isection

$$
\text { I }
$$

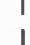

$1=\frac{1}{1}$ हो

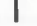

1

(1)
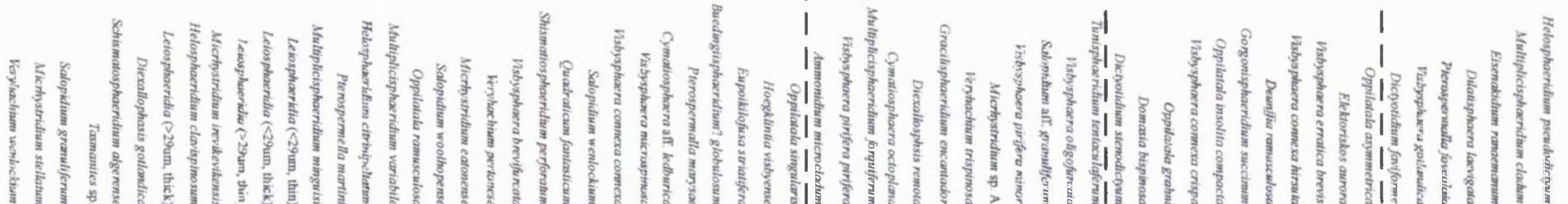

I

I

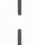

I

I

1 

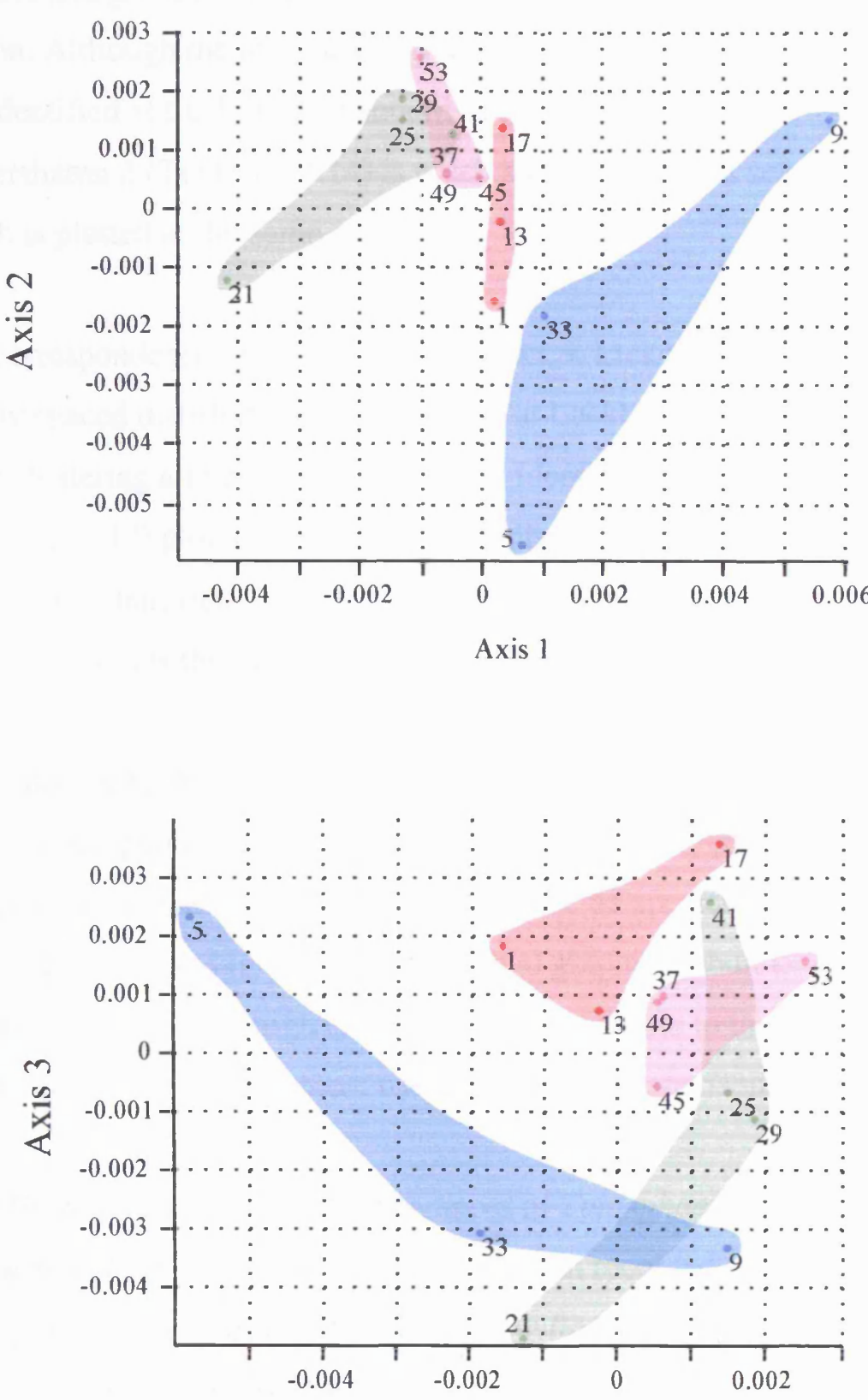

Axis 2

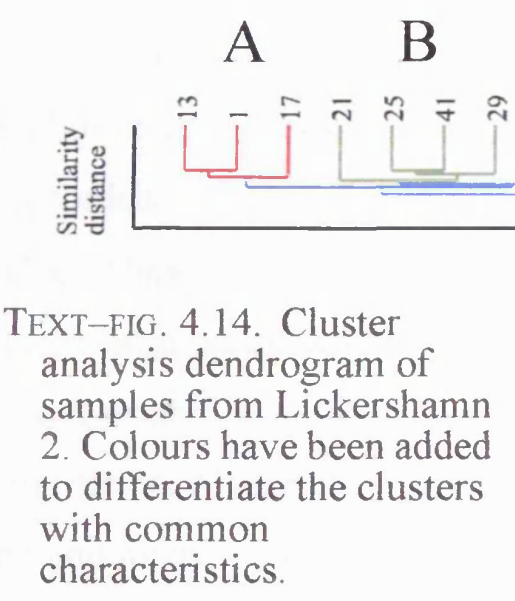

TeXT-FIG. 4.13.Plots showing the three-dimensional distribution of the samples at Lickershamn 2 after correspondence analysis (sample numbers have been included). Colours relate to clusters identified in Text-fig. 4.14

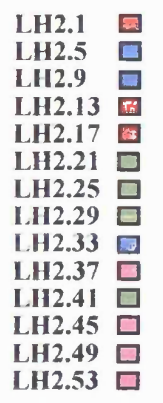

TEXT-FIG. 4.15. Table showing the cluster analysis groups identified on Text-fig. 4.14 relative to Lickershamn 2 samples in stratigraphic order 
When plotted in stratigraphic order (Text-fig. 4.15) the four groups can be identified as group C, which characterises the lower samples, the group B, which characterises the central samples and groups A and D, which mostly characterise samples from the upper part of the section. Although the individual groups appear to be much more clearly distinguished than any identified at Lusklint 1 , it should be noted that the similarity distance between samples at Lickershamn 2 (Text-fig. 4.14) is much smaller than that seen at Lusklint 1 (Text-fig. 4.9, which is plotted at the same scale).

The correspondence analysis for the species at Lickershamn 2 (Text-fig.16), again has a more widely spaced distribution than that seen at Lusklint 1 (Text-fig. 4.11). Although there is some clustering around zero, the clusters identified from the cluster analysis dendrogram (Text-fig. 4.17) plot as overlapping, but distinct groups. The specific characteristics of the clusters are identified in Text-fig. 4.17. The similarity distance recorded for the species at Lickershamn 2 is the same as for Lusklint 1 (Text-fig. 4.12).

\section{COMPARISON TO OTHER PALYNOLOGICAL STUDIES OUTSIDE OF GOTLAND}

In 1974, Hill published the stratigraphic ranges of palynomorphs from the type area of the Llandovery and the Welsh Borderland. Of the 69 species recorded by Hill, 38 have been recorded on Gotland in this study. Minimal graphical abundance data were presented by Hill (1974) which is not of high enough detail to compare to the data presented here. The range end diagrams provide the most useful basis for comparison.

Hill (1974) recorded the last appearances of Tunisphaeridium parvum and Visbysphaera meson below the Telychian, much earlier than recorded on Gotland where they were found at the top of the Visby Beds. Dilatisphaera williereae and D. laevigata were recorded as starting at a much lower level by Hill (in the Fronian and early Telychian respectively). On Gotland, D. williereae first appears in the Lower Visby Beds and D. laevigata in the Upper Visby Beds. Hill recorded a near identical level of origination for Deunffia monospinosa as that seen in Gotland, but recorded it disappearing at a lower level in type area. Hoegklintia corallina was only recorded in the late Llandovery Hughley Shales by Hill, but is not recorded until the early Wenlock Upper Visby Beds in this study. Deunffia ramusculosa was reported to have a slightly earlier origination than in Gotland, where it ranges from near the base of the section studied here. Cymatiosphaera octoplana and Pterospermella foveolata have roughly the same level of origination. Most of the species ranges identified by Hill are not comparable to those on Gotland and many have been extended in subsequent studies. 


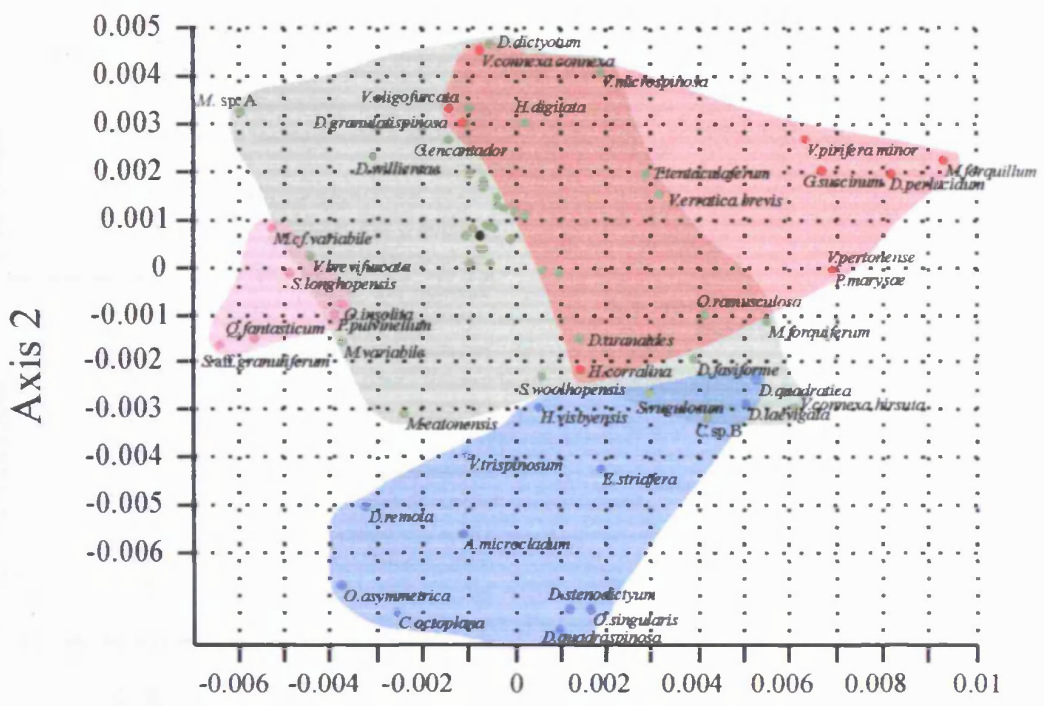

Axis 1

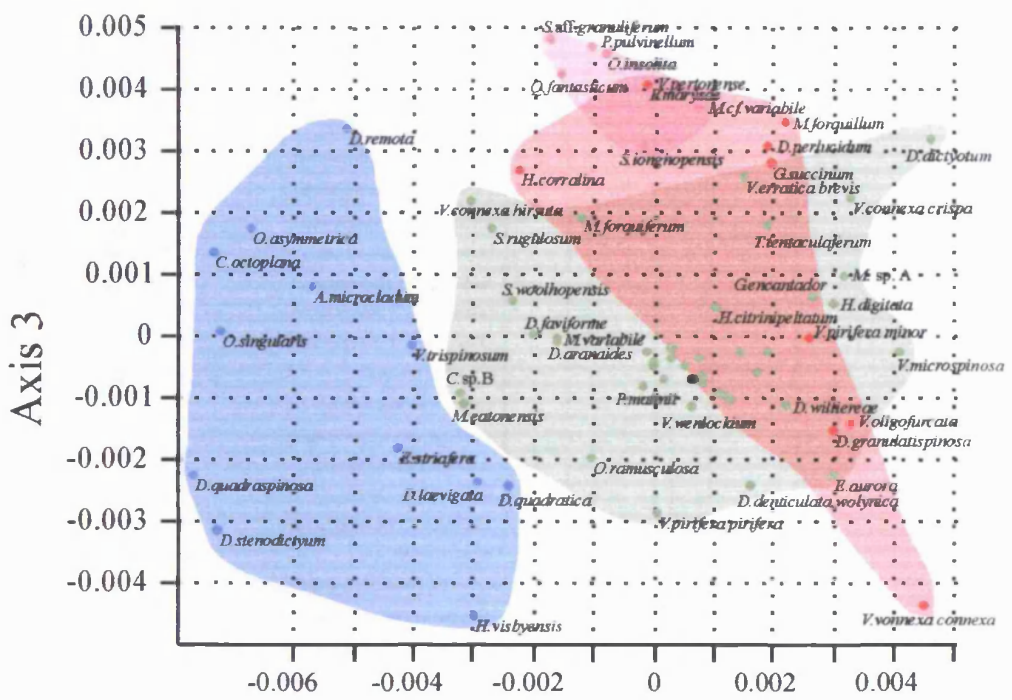

Axis 2

TEXT-FIG.4.16. Plots showing the three-dimensional distribution of the species at Lickershamn 2 after correspondence analysis (the species names for the closely clustered taxa on the plot have been removed for clarity). The colours relate to the clusters identified on Text-fig. 4.17. 


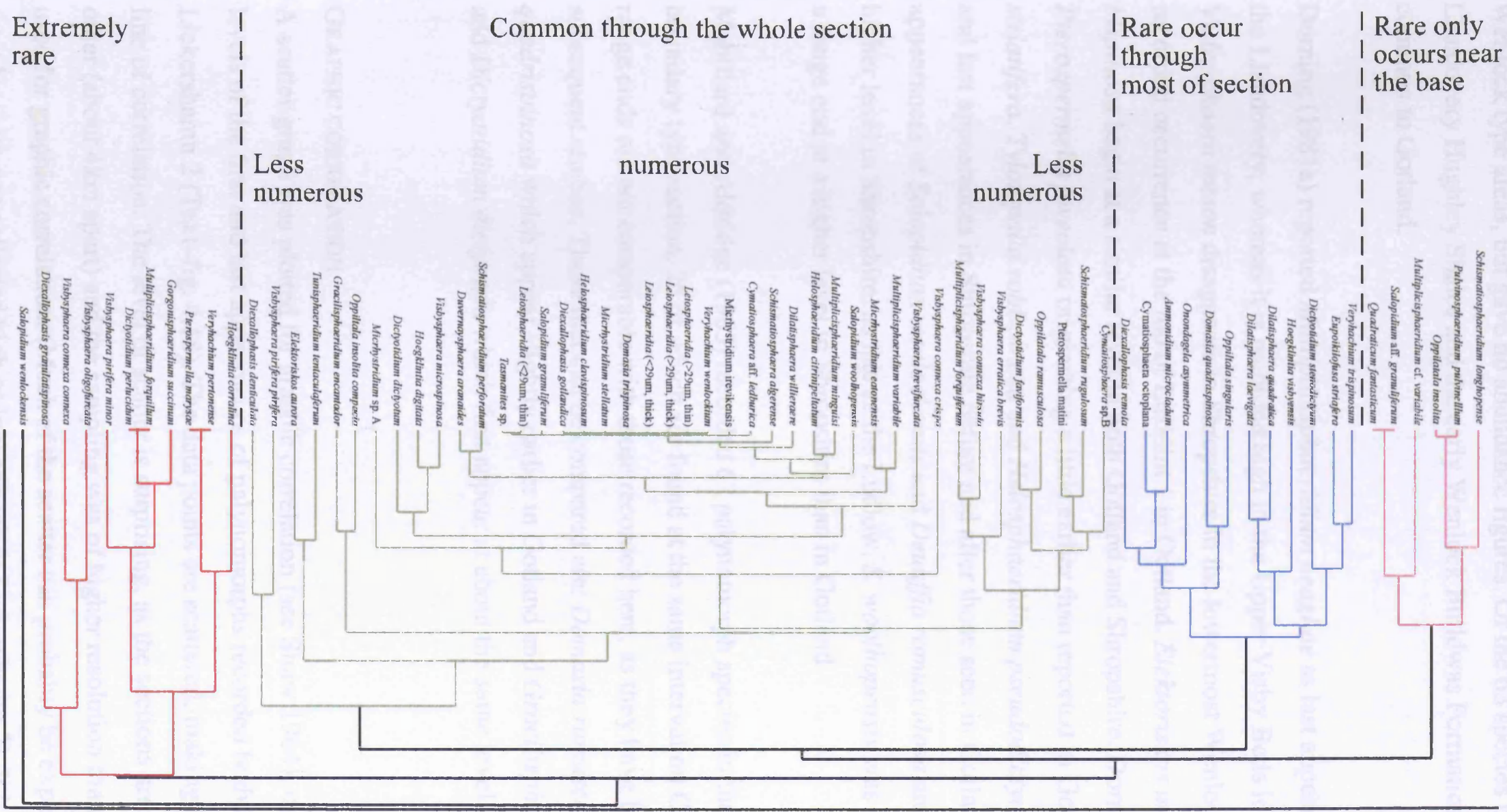

TEXT-FIG. 4.17. Cluster analysis dendrogram for species from Lickershamn 2.

Colours have been used to differentiate the clusters with common characteristics. 
Dorning (1981a) also provided comparable data for the boundary beds of the Llandovery and Wenlock type areas, but gave no abundance figures. Of the 63 species he recorded in the late Llandovery Hughley Shales and the early Wenlock Buildwas Formation, 30 species are common to Gotland.

Doming (1981a) reported Multiplicisphaeridium neaghae as last appearing in Shropshire in the Llandovery, whereas it is recorded high in the Upper Visby Beds in Gotland. Similarly, Visbysphaera meson disappears in Shropshire in the lowermost Wenlock before its last recorded occurrence at the top of Lusklint 1 in Gotland. Elektoriskos aurora and Domasia bispinasa begin at a similar level in both Gotland and Shropshire. Dorning recorded Pterospermella foveolata originating a little earlier than reported in Gotland. Eupoikilofusa striatifera, Tylotopalla robispinosa and Helosphaeridium pseudodictyum all have their first and last appearances in Shropshire before and after those seen in Gotland. The last appearances of Salopidium wenlockensis and Deunffia ramusculosa are recorded at a much higher level in Shropshire, as late as the Ludlow. S. woolhopensis was similarly recorded with a range end at a higher level in Shropshire than in Gotland.

Mabillard and Aldridge (1985) recorded 62 palynomorph species in the Llandovery/Wenlock boundary type section, 26 of which are found at the same interval on Gotland. Many of the range ends are not comparable with those recorded here, as they have been extended in subsequent studies. Those that can be compared are: Domasia ramusculosa and Domasia quadrispinosa which appear slightly earlier in Gotland and Gracilisphaeridium encantador and Dictyotidium dictyotum which first appear at about the same level in both localities.

\section{GRAPHIC CORRELATION}

A scatter graph was plotted for graphic correlation (see Shaw 1964), using the stratigraphic levels of the first and last appearances of palynomorphs recorded both at Lusklint 1 and Lickershamn 2 (Text-fig. 4.18). The data points are scattered, making it impossible to place a line of correlation. The level of scatter is surprising, as the sections are very close to each other (about 4km apart) and the sampling was of higher resolution than that of most studies used for graphic correlation. (Much of the scatter can probably be explained by the fact that samples were not collected high or low enough at Lickershamn 2). It is therefore necessary to reassess the data points. Data for species that occur in extremely low numbers or for species that gradually tail off from a previously high abundance are less reliable than those for more numerous species and for those that decline rapidly (see range end discussion above). Species 


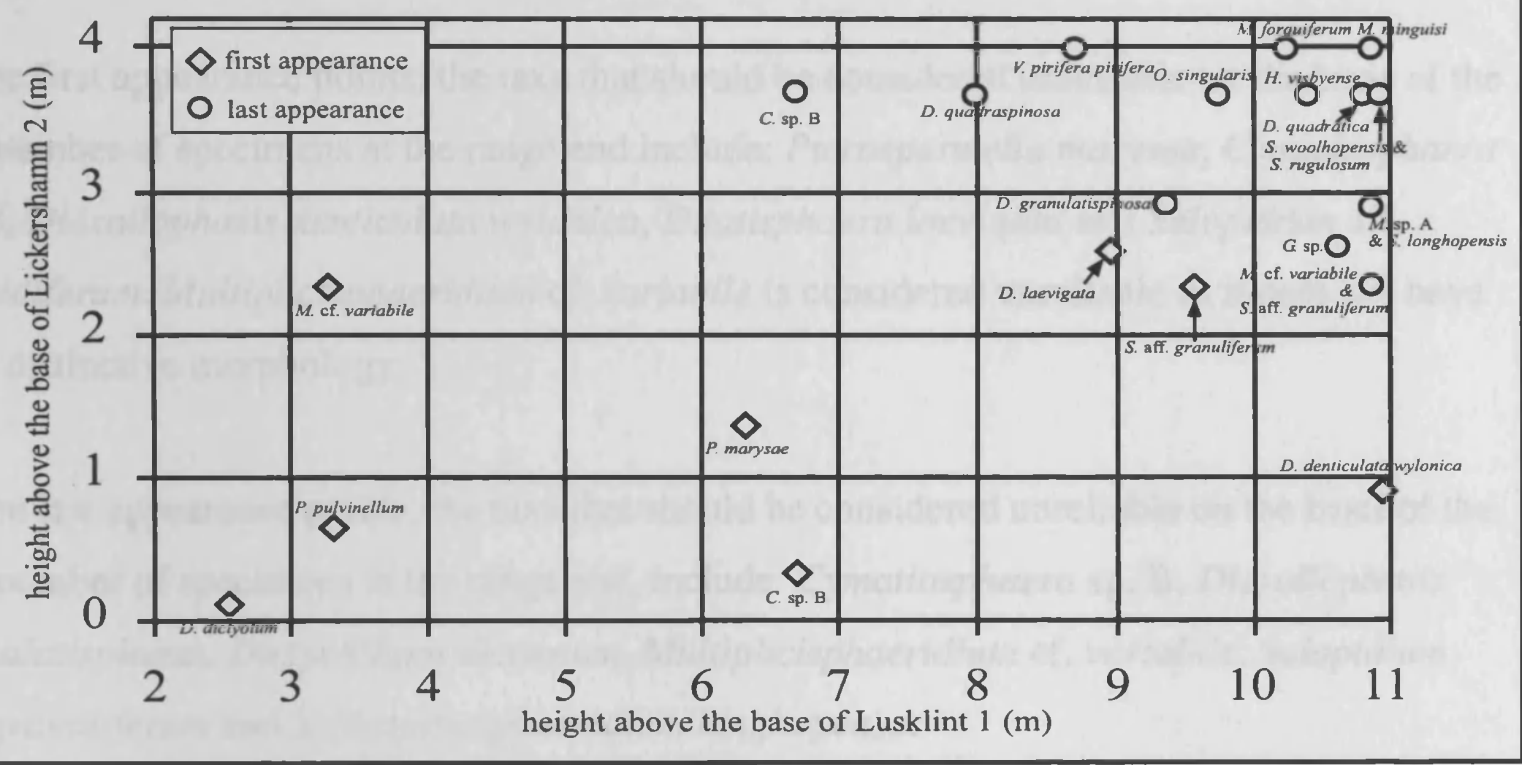

TEXT-FIG. 4.18. Graph showing all the first and last palynomorph appearance points common to both Lusklint 1 and Lickershamn 2.

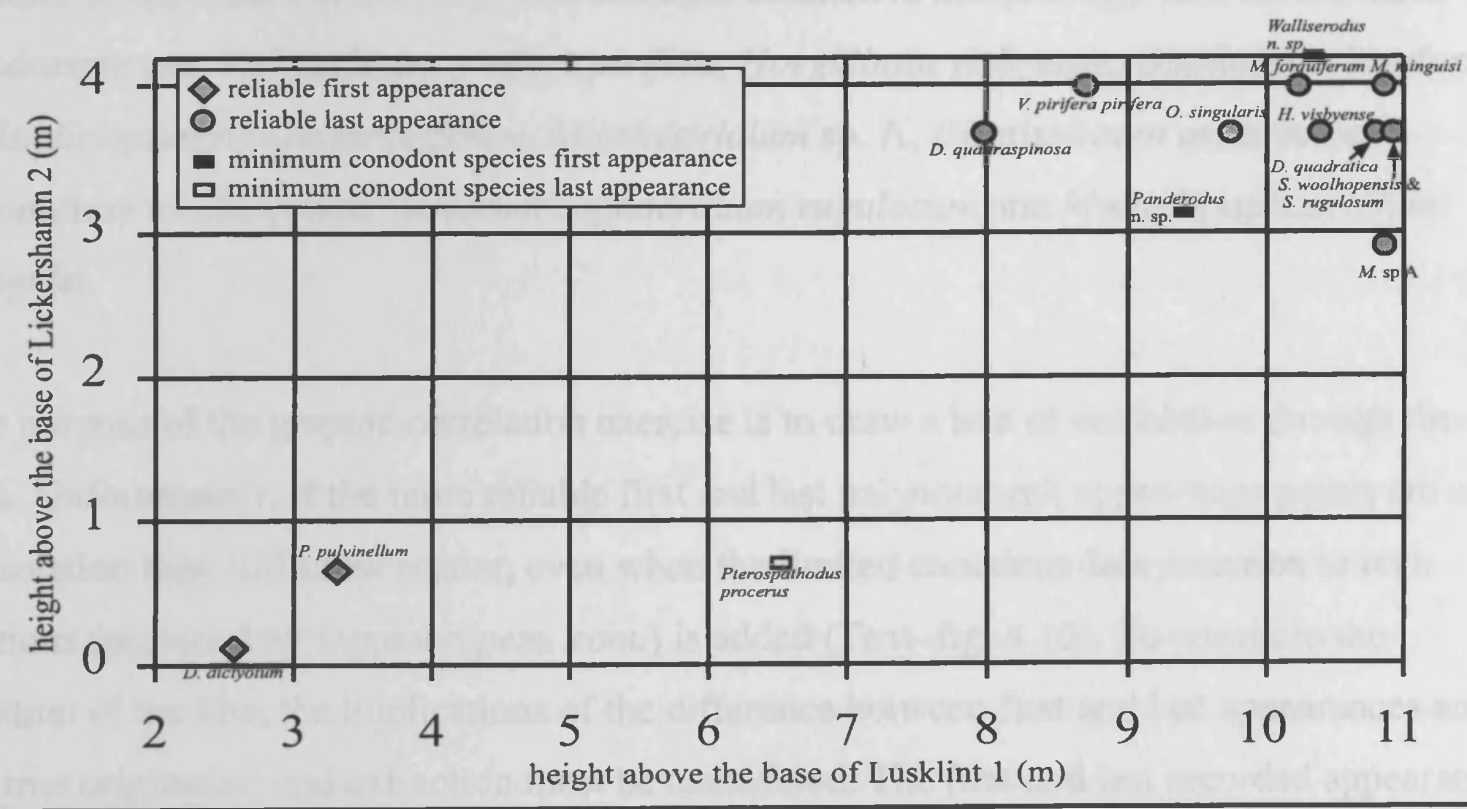

TEXT-FIG. 4.19. Graph showing the reliable first and last palynomorph appearance points and conodont first and last appearance points common to both sections. 
that were difficult to identify have less reliable range ends than those that are easily identified. The merits of the range ends of each species are discussed below:

Of the first appearance points, the taxa that should be considered unreliable on the basis of the low humber of specimens at the range end include: Pterospermella marysae, Cymatiosphaera sp. B, Diexallophasis denticulata wylonica, Dilatisphaera laevigata and Salopidium aff. granuliferum. Multiplicisphaeridium cf. variabile is considered unreliable as it does not have very distinctive morphology.

Of the last appearance points, the taxa that should be considered unreliable on the basis of the low number of specimens at the range end, include: Cymatiosphaera sp. B, Diexallophasis granulatispinosa, Dictyotidium dictyotum, Multiplicisphaeridium cf. variabile, Salopidium aff. granuliferum and Schismatiosphaeridium longhopense.

The reliable first appearance points are those of Dictyotidium dictyotum, which is both numerous and distinctive and Pulvinosphaeridium pulvinellum, which although occuring in low numbers is highly distinctive.

Of the last appearance points, the taxa that should be considered reliable on the basis of the number of specimens at the range end and their distinctive morphology include: Domasia quadraspinosa, Visbysphaera pirifera pirifera, Hoegklintia visbyense, Oppilatala singularis, Multiplicisphaeridium forquiferum, Micrhystridium sp. A, Dilatisphaera quadratica, Salopidium woolhopensis, Schismatiosphaeridium rugulosum and Multiplicisphaeridium minguisi.

The purpose of the graphic correlation exercise is to draw a line of correlation through the data. Unfortunately, if the more reliable first and last palynomorph appearance points are used in isolation they still show scatter, even when the limited conodont data common to both sections (provided by Jeppsson pers. com.) is added (Text-fig. 4.19). To constrain the position of the line, the implications of the difference between first and last appearances and the true origination and extinction must be considered. The first and last recorded appearances of a species are unlikely to be the true levels of origination or extinction, which would be at some point earlier or later in time. The line should therefore lie below the first appearance points and above the last appearance points. Uncertainty still lies in how much the range might be extended and in which section it should be extended (it is very unlikely it would be extended by the same amount in both sections). 
To further constrain the line of correlation, alternative correlation points that are represented in both sections must be sought. Unfortunately, the relative abundance data are too complex to single out precise levels that are apparent in both sections. However, the data for the number of acritarchs per gram of sediment contains four distinct peaks in the upper part of Lusklint 1 , which can be matched with smaller peaks in the number of acritarchs per gram data for Lickershamn 2 (Text-fig. 4.20 peaks A-D). When these data points are plotted they follow a near linear pattern (Text-fig. 4. 21).

At first glance, the correlation line drawn on Text-fig. 4.21 appears to solve the correlation problem, but the peaks in the number of palynomorphs per gram of sediment should be treated with caution. These points would be usable if they result purely from changes in productivity, but this may not be the case. The number of palynomorphs per gram of sediment is dependent on many factors, such as preservation potential, sedimentation rate, and nutrient levels, but most of all it is dependent on lithology. Limestones are much more competent than marls and therefore undergo much less compaction than the same original thickness of marl. A given thickness of limestone today, therefore represents a shorter period of time than the equivalent thickness of marl. The smaller the amount of time represented, the fewer the number of palynomorphs. Hence, the peaks could merely represent changes in lithology between limestone and marl, which occur regularly through the whole of both sections.

At Lusklint 1, peak A is formed by sample DG00LK1.167, which is a marl. The sample directly before that is another marl, but the two samples below that (forming the trough on Text-fig. 4.20) are both limestones. Above peak A, the three samples are all limestones. Peak B (sample DGO0LK1.183, a marl), is preceded by the same three limestone samples (forming the trough) and followed by three marl samples. Peak C (sample DG00LK1.211, a marl) is preceded by three limestone samples and followed by a limestone/marl sample. Peak D (sample DG00LK1.223), contrary to the prediction of the peaks being made up of marl surrounded by limestone samples, is a limestone preceded by a marl and a limestone/marl sample. Above this are two limestone samples. All the samples analysed at Lickershamn 2 (apart from two limestone/marl samples) are limestone.

Shaw (1964) used least squares linear regression to calculate the line of correlation, but this method does not take into account the relative significance of appearances, or disappearances of different species (see discussion in MacLeod \& Keller 1991, p. 1442). The line drawn here cannot be fully trusted, but it is a best estimate with the available data and fits with the 


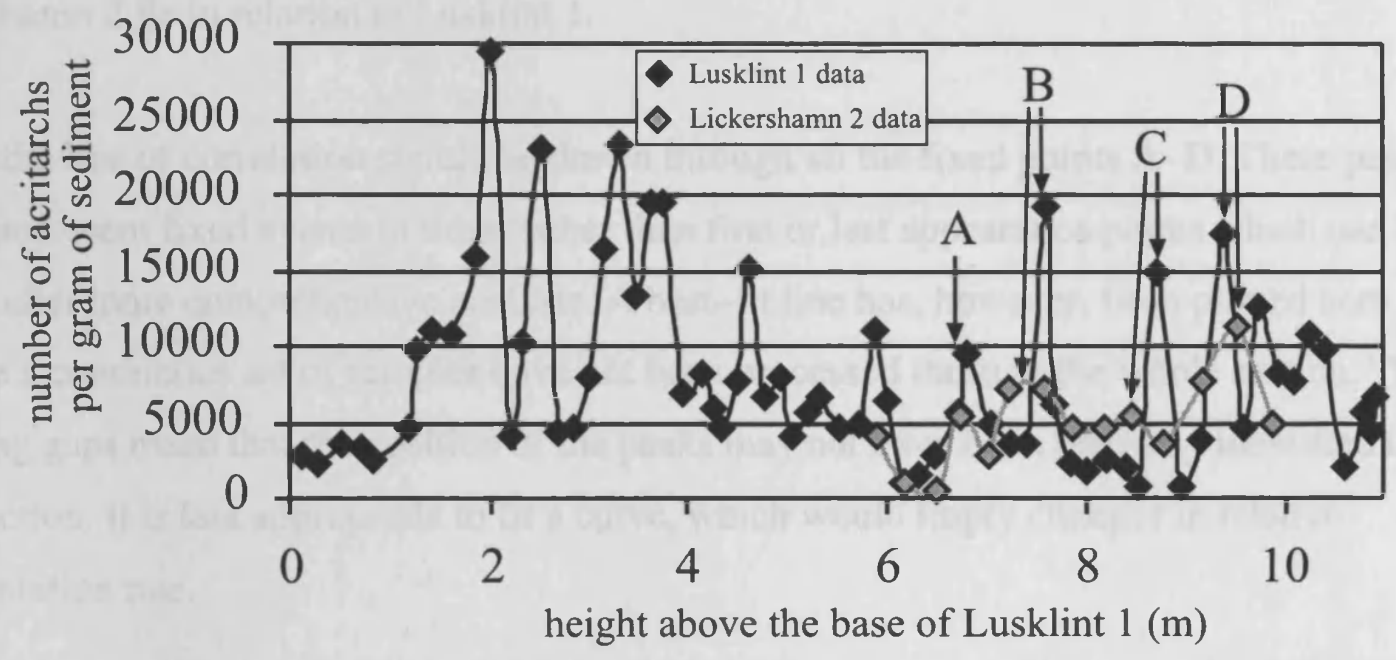

TEXT-FIG. 4.20. Graph showing the number of palynomorphs per gram of sediment at Lusklint 1 and Lickerhamn 2. The Lickershamn 2 data has been superimposed (at the same scale) onto the Lusklint 1 plot. Peaks common to both sections have been labelled).

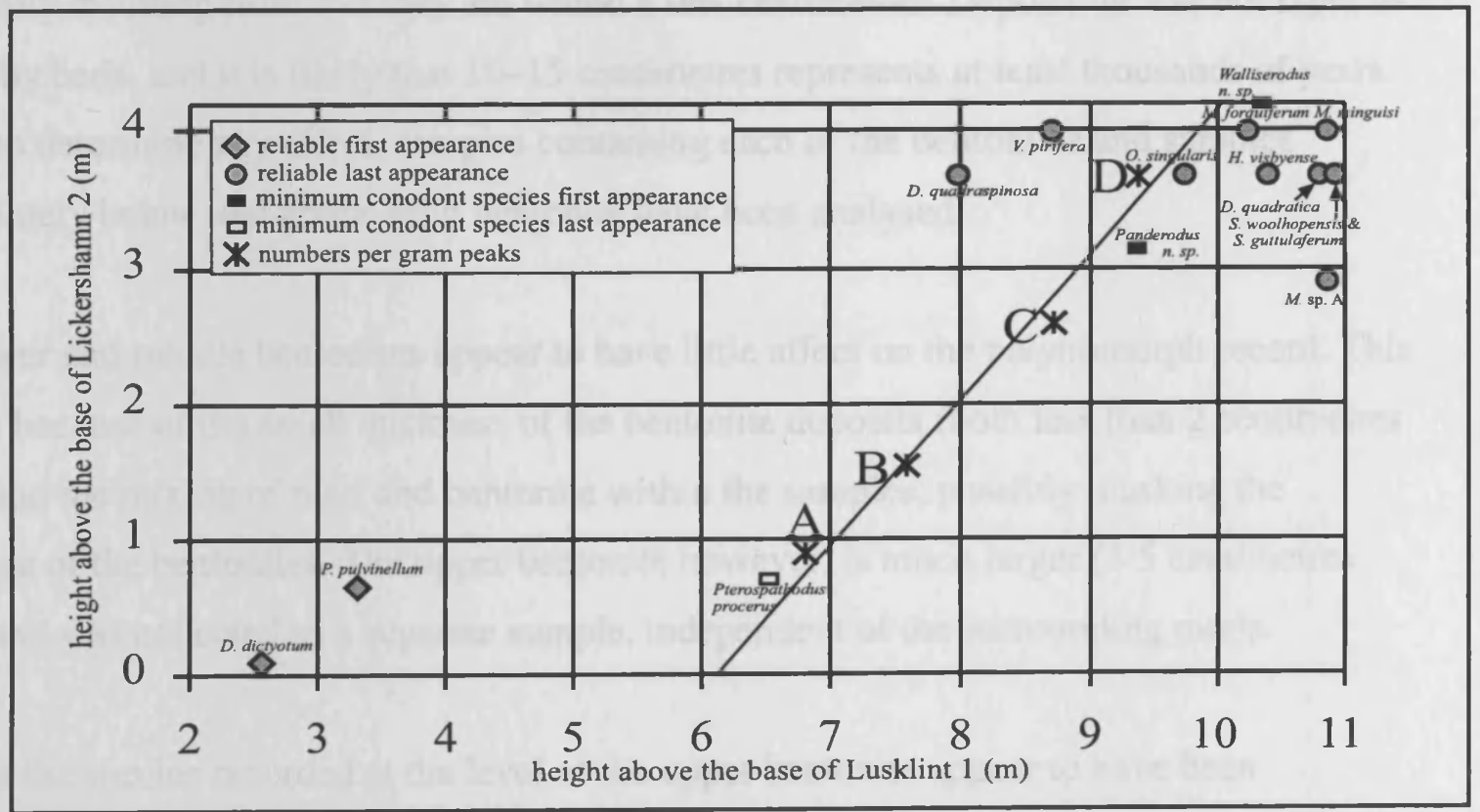

TEXT-FIG. 4.21. Graph showing the reliable first and last palynomorph appearance points, conodont first and last appearance points and number of palynomorphs per gram of sediment peaks common to both sections. A correlation line has been drawn based upon points $\mathrm{A}-\mathrm{D}$. 
conodont first and last appearance points. The gradient of the line is $45.8^{\circ}$, which forms a ratio for Lusklint 1 to Lickershamn 2 of 1:1.03. The correlation line intercepts the Lusklint 1 axis at $6.08 \mathrm{~m}$ and $10.04 \mathrm{~m}$, which represents where the base and top of the sampled section at Lickershamn 2 lie in relation to Lusklint 1.

Ideally the line of correlation should be drawn through all the fixed points A-D. These peaks should represent fixed events in time, rather than first or last appearance points which can be moved after more comprehensive analysis. A best-fit line has, however, been plotted here because a continuous set of samples have not been processed through the whole section. The sampling gaps mean that the position of the peaks may not have been precisely identified in each section. It is less appropriate to fit a curve, which would imply changes in relative sedimentation rate.

\section{THE EFFECT OF BENTONITE DEPOSITION ON THE PALYNOMORPH RECORD}

In the context of the changes in the palynomorphs during the Ireviken Event, the effect of bentonite deposition is difficult to decipher. Any variations in the abundances before, or directly leading up to, the deposition can be regarded as influenced by factors other than the bentonite. Variations occurring after the deposition of the bentonite can only be regarded as potentially resulting from it if they are within a few centimetres. Deposition was not rapid in the Visby beds, and it is likely that 10-15 centimetres represents at least thousands of years. To try to determine any effect, samples containing each of the bentonites and samples immediately below and above each bentonite have been analysed.

The lower and middle bentonites appear to have little affect on the palynomorph record. This may be because of the small thickness of the bentonite deposits (both less than 2 centimetres thick) and the mixing of marl and bentonite within the samples, possibly masking the influence of the bentonites. The upper bentonite however, is much larger $(5.5$ centimetres thick) and was collected as a separate sample, independent of the surrounding marls.

Most of the species recorded at the level of the upper bentonite appear to have been unaffected by the ash fall; species that show a detectable abundance change have been plotted on Text-fig. 4.22. The number of palynomorphs per gram of sediment shows a sharp drop 

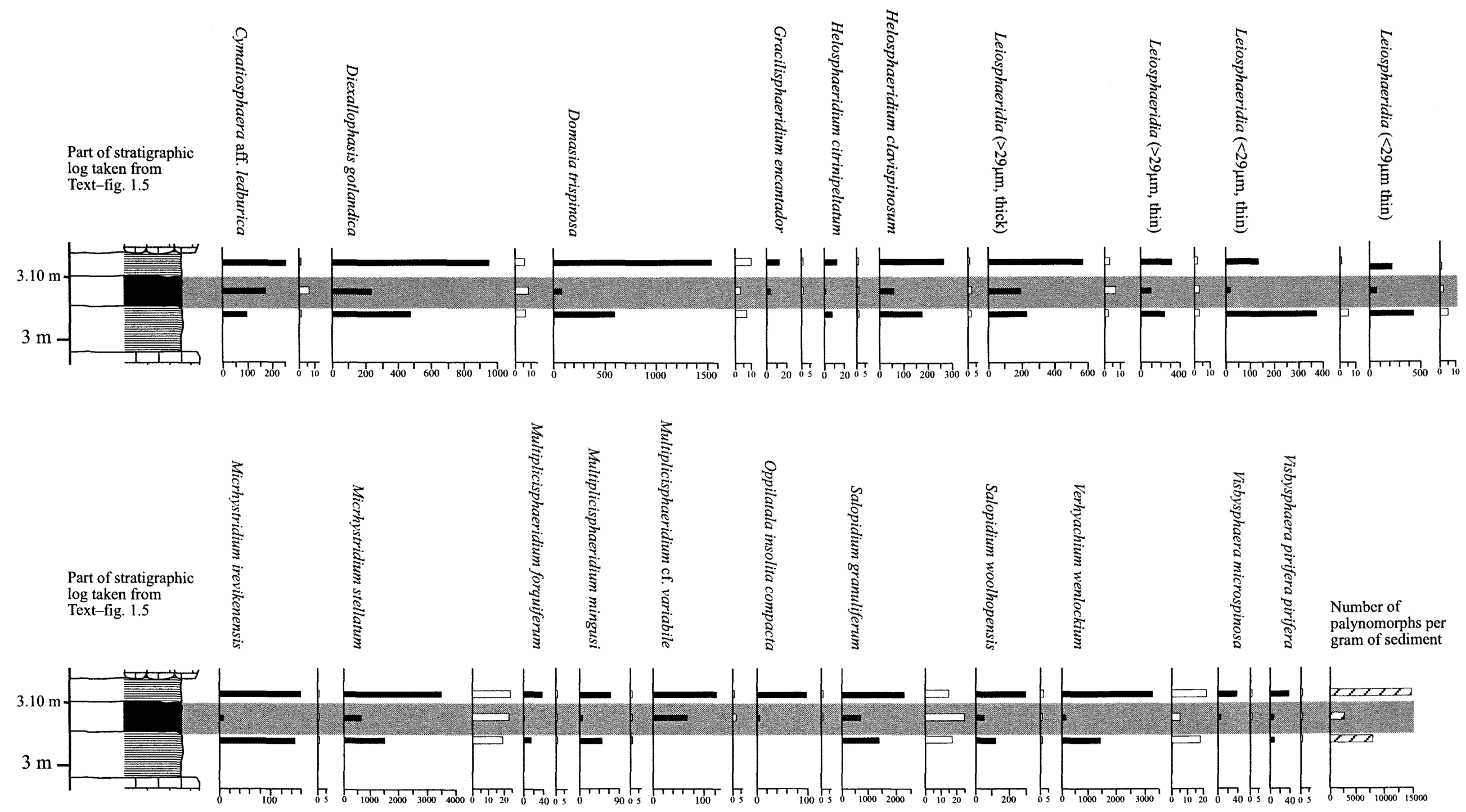

TEXT-FIG.4.22. Graph showing the absolute abundance of selected species (black bars), percentage abundance of selected species (white bars) and number of palynomorphs per gram of sediment (patterned bars), across the upper bentonite. 
from 7755 before the bentonite to 1656 within the bentonite, then rising to 14670 after. Most species reflect these figures without changes in relative abundance, which are only apparent in a few taxa. Cymatiosphaera aff. ledburica shows a slight increase from $1 \cdot 29 \%$ before the bentonite, to $6.74 \%$ in it, falling to $1.81 \%$ after. Micrhystridium stellatum and Salopidium granuliferum also show an increase in percent abundance within the bentonite. This level is maintained in $M$. stellatum, but falls again to $15.61 \%$ in S. granuliferum. Veryhachium wenlockium has a fall in percent abundance at the bentonite, from $18.0 \%$ to just $5.35 \%$. The proportion instantly recovers to previous levels above. Domasia trispinosa falls from $7 \cdot 92 \%$ before the bentonite to $3 \cdot 16 \%$ within it, but again recovers to $10 \cdot 87 \%$ after.

\section{THE GEOCHEMICAL RECORD}

\section{Stable carbon and oxygen isotope data for Lusklint 1}

Dr. Richard Corfield and Dr. Derek Siveter of the University of Oxford have collected samples for analysis of stable carbon and oxygen isotopes, from Lusklint 1. Their samples were collected from $8.75 \mathrm{~m}$ below the base of the section sampled here, to $10.89 \mathrm{~m}$ above (see Appendix 9). Corfield and Siveter have kindly made their data available for comparison with the acritarch record.

Between $-8 \mathrm{~m}$ and $4 \mathrm{~m}$, the carbon stable isotope data (Text-fig. 4.23) shows a roughly consistent signature, with a $\delta^{13} \mathrm{C}$ value of around 1.5 . The samples below $-8 \mathrm{~m}$ have $\delta^{13} \mathrm{C}$ values of around 1.8. Above $4 \mathrm{~m}$ the samples show a rising trend, from around 1.6 to 4.2. The $\delta^{13} \mathrm{C}$ values in the upper part of Lusklint 1 are more variable than those from the lower part of the section.

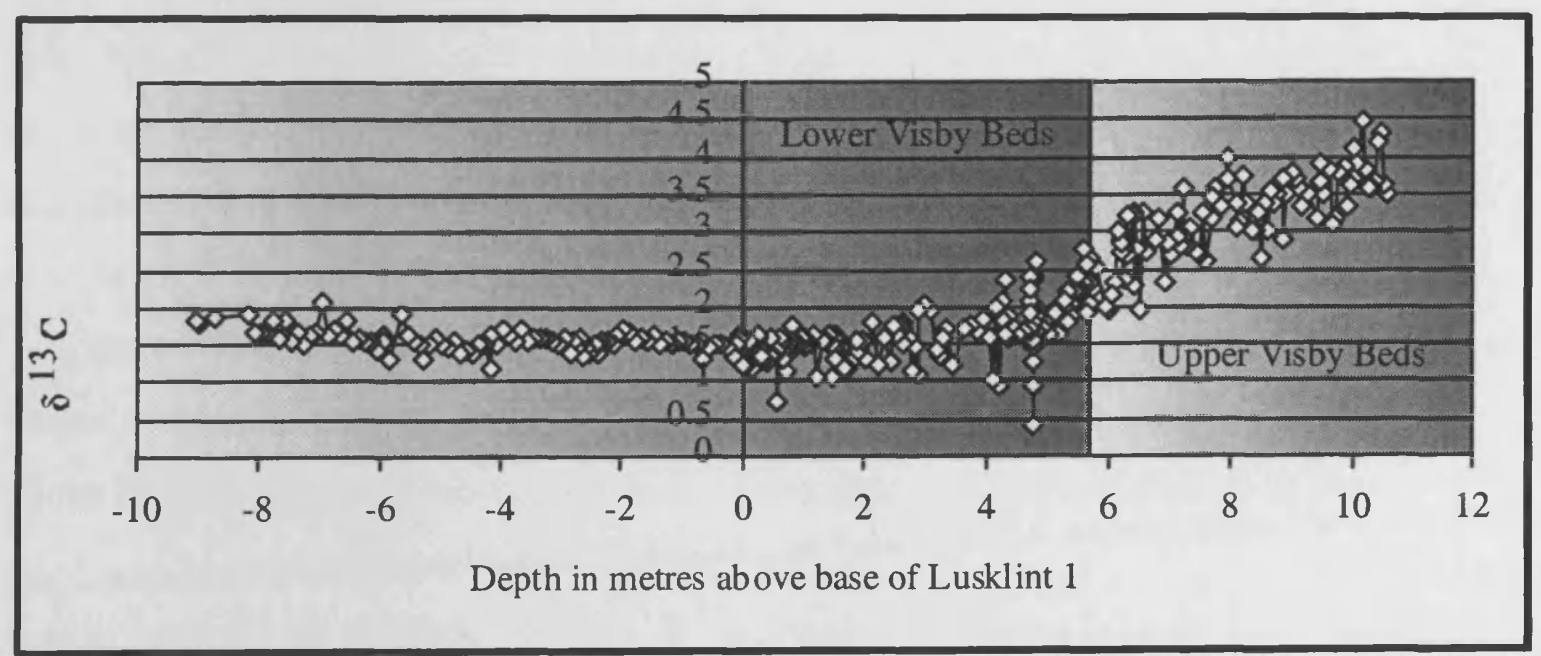

TEXT-FIG. 4.23. Graph showing the $\delta^{13} \mathrm{C}$ whole rock analysis relative to the base of the section sampled for this study, data provided by Corfield and Siveter. 
The oxygen stable isotope data (Text-fig. 4.24) show a roughly consistent signature mostly falling within the -5 to -6 range. There are a number of outliers (e.g. the sample at $4.79 \mathrm{~m}$ has a value of -3.5 ), which can probably be disregarded as an experimental error. The main deviation from the steady state values occurs at around $9 \mathrm{~m}$ to $9.5 \mathrm{~m}$, where a fall to a $\delta^{18} \mathrm{O}$ value of around -6 and subsequent rise to previous levels, is recorded.

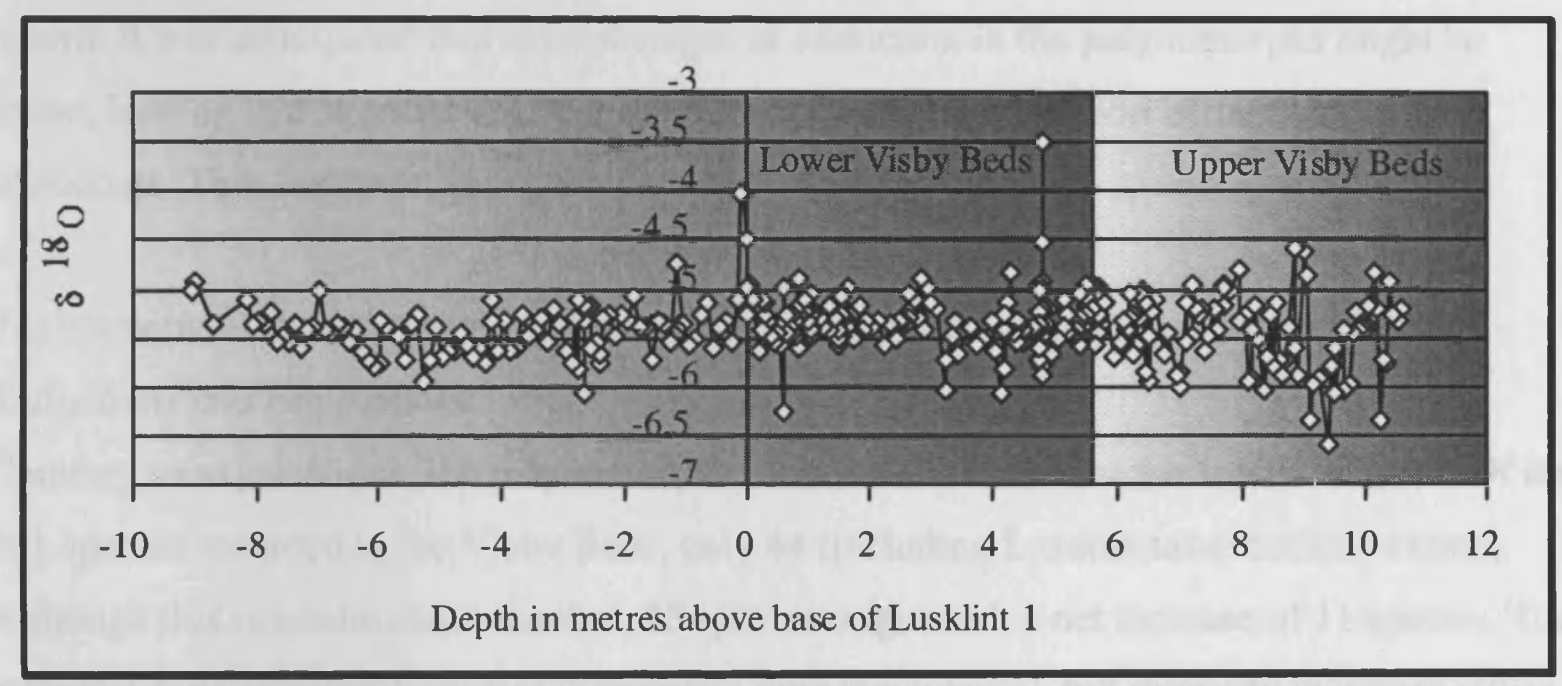

TEXT-FIG. 4.24. Graph showing the $\delta^{18} \mathrm{O}$ whole rock analysis relative to the base of the section sampled for this study (data provided by Corfield and Siveter. 


\section{DISCUSSION AND CONCLUSION}

The main aims of this study were to investigate the palynomorph record through the Ireviken Event and to endeavour to relate the changes recorded to possible climate and sea-level changes and to the highly detailed conodont record for this time. The presumption was that the devastating extinction seen in the conodonts would be mirrored in the palynomorph record. It was anticipated that several stages of extinction in the palynomorphs might be found, leading to a stepwise collapse in the food-web and knock-on extinctions in the conodonts. This, however, is not the case.

\section{PALYNOMORPH EXTINCTIONS, ORIGINATIONS, ABUNDANCE CHANGES AND MIGRATIONS Extinctions and originations}

Contrary to expectations, the palynomorphs were not devastated at the Ireviken Event. Of the 111 species reconded in the Visby Beds, only 44 (including Lazarus taxa) became extinct. Although this is a substantial number, 55 species originated, a net increase of 11 species. The turnover in palynomorph species is dramatic over this interval, but diversity increases rather than decreases. The stratigraphic range plots constructed by Le Hérissé (1989) for the Visby Beds also show this pattern, with 43 species becoming extinct and 54 originating.

Most of the species that originated and/or became extinct are from the genera Multiplicisphaeridiuan, Oppilatala, Pterospermella, Salopidium, and Visbysphaera. It is suggested that these genera contain species that lie at the very edge of their environmental tolerances. The species that became extinct would have found it difficult to tolerate environmental change and the species that originated were probably pioneers moving into new niches that the more established species could not tolerate. Although these complex patterns are difficult to explain, it is possible that changing sea-level and environment were gradually creating new global and local niches through the whole of the Ireviken Event. The gentle pace of these changes enabled a steady increase in the number of species. The absence of a gradual extinction pattern may be because the palynomorphs could tolerate small gradual changes without becoming extinct, but once the cumulative effect of these changes had become large enough, a more sudden and concentrated set of extinctions took place.

Altematively, environmental changes may have been gradual through most of the event (stimulating the gradual originations as new niches opened up), apart from the end where more severe changes took place. The palynomorphs may have been able to tolerate the gradual changes, but not the more severe later stage ones. 
A further line of evidence to suggest that the palynomorphs were more environmentally tolerant than previously suggested lies in the relationship with the conodonts. At the outset of this study, the hypothesis was forwarded that the extinction of palynomorph species might have directly, or indirectly caused the extinction of conodont species. For this, a step-wise extinction pattern, close to that of the conodonts would be predicted. The original hypothesis assumed that the acritarchs were more climate sensitive than the conodonts and became extinct first, but the data show that the palynomorph extinctions followed those of the conodonts. This suggests the conodonts were more environmentally sensitive than the palynomorphs.

\section{Range end confidence limits}

Graphic correlation between Lickershamn 2 and Lusklint 1 suggested that in many cases the recorded palynomorph range end points are not representative of the true range ends (especially where the range end currently lie at the position of the highest or lowest sample in either section). The range end statistical analyses attempted in this study proved inconclusive; future analysis utilising all available data is suggested.

\section{Multivariate analysis}

The multivariate analysis carried out on the abundance data from Lusklint 1 shows three distinct groups of samples in the bottom, middle and top of the section. The base is dominated by higher $M$. stellatum, V. wenlockium and S. granuliferum; the middle by low levels of $M$. stellatum and $V$. wenlockium and a higher number of $S$. granuliferum; the top by abundant $M$. stellatum and $V$. wenlockium and less abundant $S$. granuliferum. These variations are independent of lithology (which is very different at the top and bottom of Lusklint 1) and may reflect changes in sea level or climate. Seven groups of species with comparable distributions were identified at Lusklint 1 , the largest of which is made up of the most common species. The apparent sensitivity of the commonly occurring species over others to the changes occurring at this time may be a reflection of their greater number, but may also reflect a relatively enhanced sensitivity to sea level and environmental change.

The repetition of cluster analysis sample groups at both the base and the top of Lusklint 1 , suggests the possibility of a cycle. It is difficult to identify the cause, but a cyclic change in sea level, or climate may be responsible. Until the analysis of samples that extend the stratigraphic range of the section is conducted the extent and reliability of this signal cannot be assessed. 
The multivariate analysis carried out for Lickershamn 2 gave much more distinct patterns, probably because of the smaller number of samples analysed. The samples could be split into three similar groups, again representing the bottom, middle and top of the section. These groups probably reflect a lower number of the more common species at the base of the section, slightly higher in the central section and higher still in the top part of the section. Four groups of species with similar distributions in Lickershamn 2 were identified, mostly characterised by a similarly rare or similarly common occurrence.

\section{Comparison to other palynological studies outside of Gotland}

There are three main problems associated with comparisons to other palynological studies: the unprecedented high resolution of sampling in this study, the level of detail recorded when the samples were logged and the unknown level of the Llandovery/Wenlock boundary and graptolite zones on Gotland.

A summary of the probable migrations between Gotland and the Welsh Basin is made in Text-fig. 5.1, although these may be revised with more precise data from the British sections. Migrations into Gotland are classed as species that are first recorded in the Welsh Basin and later in time in Gotland. Migrations into the Welsh Basin are classed as species that are first recorded in Gotland and then later in time in the Welsh Basin. At present, this comparison suggests there were a slightly more migrations out of Gotland to the Welsh Basin (seven out and three into Gotland).

\begin{tabular}{|c|c|c|}
\hline \multirow[t]{2}{*}{ Author } & \multicolumn{2}{|l|}{ Migration } \\
\hline & To Gotland & To the Welsh Basin \\
\hline Hill 1974 & $\begin{array}{l}\text { D. laevigata } \\
\text { D. williereae } \\
\text { H. corallina }\end{array}$ & D. ramusculosa \\
\hline Dorning 1981a & & $\begin{array}{l}\text { D. ramusculosa } \\
\text { P. foveolata } \\
\text { S.wenlockense } \\
\text { S. woolhopensis }\end{array}$ \\
\hline $\begin{array}{l}\text { Mabillard \& } \\
\text { Aldridge } 1985\end{array}$ & & $\begin{array}{l}\text { D. quadrispinosa } \\
\text { D. ramusculosa }\end{array}$ \\
\hline
\end{tabular}

TEXT-FIG. 5.1. Summary of the apparent migrations in and out of Gotland and the Welsh Basin at the Llandovery/Wenlock boundary. 
This comparison is very limited and without reliable abundance data for both areas an estimation of how favourable the conditions in each area was, cannot be made.

The mostly consistent pattern of earlier originations than in Gotland recorded by Hill (1974), suggests that at least three species migrated into the Baltic once they had become established in the type area. When the results of Dorning (1981a) are compared to the data presented here it is found that four species originated earlier in Gotland and then presumably migrated to the Welsh Basin.

The work of Mabilland and Aldridge (1985) was of high resolution (about half that of this study), but of the 62 species recorded, only 26 are found at the same interval on Gotland. On comparison to the present study two originations appear earlier in Gotland suggesting these species migrated from Gotland to the Welsh Basin at this time.

\section{THE RESPONSE OF THE PALYNOMORPHS TO THE DEPOSITION OF THE UPPER BENTONITE}

The palynomorphs recovered from the bentonite sample show a marked drop in the number per gram of sediment. In the sample above, collected from the following few centimetres, a marked rise in number is recorded. Most species simply reflect this by increasing in number and do not change their relative abundance. The change in number is probably mostly a result of the different amounts of time being sampled. The bentonite most likely represents a single eruption, at most lasting several years, whereas the subsequent marl deposit probably represents hundreds, if not thousands of years. Alternatively, the change in number may in part be a direct result of the deposition of the bentonite. During bentonite deposition the short-term oceanic conditions may not have been very good for the palynomorphs, blocking out light and smothered them. In the slightly longer term the fertilizing potential of the bentonite could have caused a recovery, with numbers reaching a higher level than before the bentonite. Cymatiosphaera aff. ledburica, Micrhystridium stellatum, Salopidium granuliferum, Domasia trispinosa and Veryhachium wenlockium are most affected by the bentonite. $C$. aff ledburica, $M$. stellatum, and $S$. granuliferum all increase their percent abundance in the bentonite sample and $D$. trispinosa and $V$. wenlockium decrease their percent abundance. All the species apart from $M$. stellatum (which continues to increase in percent abundance) return to their previous abundance levels after the eruption. It can therefore be concluded that these five species are the most bentonite sensitive. The lower and middle bentonites have no observed affect on the palynomorph record. There are no originations or extinctions specifically associated with any of the bentonites, other than those consistent with the patterns associated with the whole section. 
Vary fow studies have been published on the effects of bentonites on planktonic communities. Perhaps the publication most applicable to this study is by Rigby and Davies (2000), who analysed the response of graptolites to the introduction of ash to the Llandovery ocean. They reported a plankton bloom immediately above a bentonite horizon (as reported here) and suggested this was stimulated by an influx of nitrogen, phosphates and silicon, in conjunction with the increased micronutrients including iron. 'Fresh' iron (hydrolysed $\mathrm{Fe}^{3+}$ ) is more readily absorbed by plankton, rather than the older iron, which, becomes progressively more colloidal and less reactive (Davis 1967). The influx of ash into the ocean system would be a ready source of $\mathrm{Fo}^{3+}$ and a massive bloom stimulant. It has been shown by Watson (1997), that inputs of voleanogenic iron (in this case from Mount Pinatubo into the Southern Ocean where iron is limiting) produce a huge rise in primary productivity. Ash from the Iceland 2000 Hekla eruption (Frogner 2001) has been shown to produce a rapid release of 'bioactive trace metals... available to support primary production'. Strong (1993) reported observations that show the eruption of El Chichón in 1982 produced a rapid and dramatic reduction in phytoplankton concentrations in the summer and autumn of that year. The longer-term effects were not discussed.

Botting (1999) suggested that volcanic eruptions in the Ordovician did not generate an instant response in the plankton (in this case graptolites and pseudoplanktic inarticulate brachiopods). An increase in absolute abundance was calculated to have occurred 100-200 years later (determined from the mean sedimentation rate calculated from the duration and thickness of the teretiusculus Biozone). This abundance increase was suggested to have been caused by an upwelling of nutrients initiated by the descent of dense ash-rich water. Contrary to the interpretations made here, the nutrient rich ash was suggested to have generated no direct response. Botting $(1999$, p. 502$)$ argued that a feedback loop is likely to have been set up whereby plankton blooms produced a high influx of nutrients to the benthos, which then perpetuated the benthos and promoted continued circulation. The mechanism by which the benthos perpetuated the circulation was not discussed.

It is possible that a delayed response of the plankton to the deposition of volcanic ash, as reported by Botting, might be present at Lusklint 1 (the signal could be included within the sample directly above the bentonite and now seen in the absolute abundance data). At present it is not possible to confirm this, as the thickness of sediment at Lusklint 1 represented by 100-200 years is unknown. A comparison to the patterns Botting recorded is further complicated because graptolites and pseudoplanktic inarticulate brachiopods are unlikely to 
havereacted in the same way as palynomorphs to a volcanic eruption. The volcanic deposit is likely to be different at different localities, varying in chemistry, grain size and residence time in the water column, which would all make a significant difference to the response of the plankton. It is possible that the feedback loop suggested by Botting occurred on Gotland, but at this stage this is impossible to test.

Around the Llandovery/Wenlock boundary volcanism was geographically widespread, ranging from Gotland (Laufeld 1976), to the British Isles (Fortey et al. 1996), to Australia (Jones et al. 1995). It was also temporally widespread through the Silurian; for example, there are numerous bentonites in the Ludlow (Mullins 2001). The volcanism seen at Lusklint 1 was probably not significant enough to cause extinctions. Most of the palynomorph extinctions recorded are significantly later than the bentonite layers and bentonites recorded elsewhere in the Silurian are not associated with extinctions.

\section{GRAPHIC CORRELATION}

One of the main conclusions that can be drawn from the graphic correlation exercise is that the sections are not long enough for reliable results, especially as there are no common marker horizons. The other main conclusion is, that if the correlation line is correct or even roughly correct, the sampled interval at Lickershamn 2 does not extend Lusklint 1; it just repeats part of it. The $45.8^{\circ}$ angle of the correlation line suggests that the overall sedimentation rate at the two sections is almost identical with a slightly faster rate at Lickershamn 2. If the correlation line is correct, the range ends of the conodonts are more reliable for correlation than those of the acritarchs. Further sampling above and below both sections needs to be carried out to determine precisely the correlation of the sections. Using another analytical method such as magnetic susceptibility (Ellwood et al. 2001) may be an alternative way of solving the problem.

\section{THE GEOCHEMICAL RECORD}

\section{Stable carbon and oxygen isotope data for Lusklint 1}

The stable isotope data, provided by Corfield and Siveter and used here, are derived from the analysis of whole rock samples and reflect the nature of the isotopes buried in the sediment not those present in the ocean.

Plankton preferentially incorporate $\delta^{12} \mathrm{C}$ rather than $\delta^{13} \mathrm{C}$ during photosynthesis, providing a mobile sink for $\delta^{12} \mathrm{C}$. When the ocean was well mixed (Text-fig. 5.2) low levels of plankton were incorporated into the sediment, as there was little opportunity for them to settle to the 
seafloor. Relatively low levels of $\delta^{12} \mathrm{C}$ were incorporated into the sediment (i.e. whole rock samples), whereas high levels might have occurred in the ocean (and be reflected in samples purely analysed from brachiopod shells secreted in equilibrium with the oceanic water).

When the ocean became stratified (Text-fig. 5.2) undisturbed settling of plankton to the seafloor occurred, favouring incorporation of plankton into the sediment. The removal of plankton (rich in $\delta^{12} \mathrm{C}$ ) from the ocean system, would have given a relatively rich $\delta^{13} \mathrm{C}$ ocean (recorded in brachiopod shell samples) and a $\delta^{12} \mathrm{C}$ rich sediment (recorded in whole rock samples). Therefore, the sedimentary $\delta^{12} \mathrm{C} / \delta^{13} \mathrm{C}$ ratio in both oceanic circulation states was very different from that of the ocean.

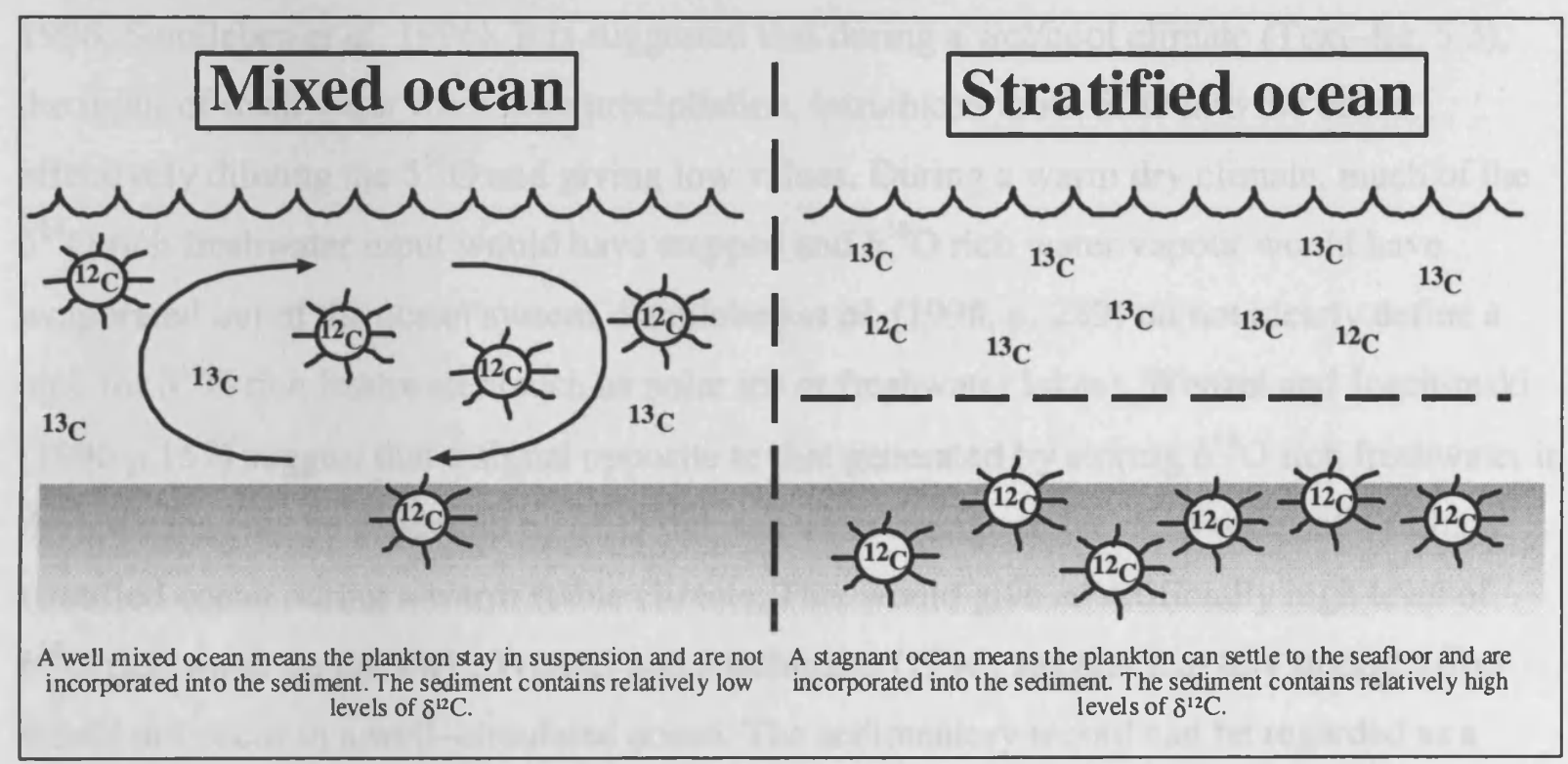

TEXT-FIG. 5.2. Cartoon showing the relative levels of $\delta^{12} \mathrm{C}$ incorporation into oceanic sediment, in a well-mixed and a stratified ocean.

Primary productivity undoubtedly had a very large influence on the preserved carbon isotope record. If many more plankton were present in the oceans at a particular time, the amount that became incorporated in the sediment must have been greater than during times of lower productivity, independent of the oceanic circulation conditions. This would increase the resulting $\delta^{12} \mathrm{C}$ value, as a greater number of $\delta^{12} \mathrm{C}$ rich plankton would be incorporated into the sediment. It cannot be assumed that the productivity through the entire Ireviken Event was constant; most likely it changed with climate and/or sea level changes.

For much of the geological record, the oxygen stable isotope record is interpreted as indicative of palaeotemperature. It is suggested that during glacial periods the oceans become progressively depleted in $\delta^{16} \mathrm{O}$. This is because the lighter $\delta^{16} \mathrm{O}$ is preferentially removed from 
the oceans during evaporation, rather than the heavier $\delta^{18} \mathrm{O} . \delta^{16} \mathrm{O}$ rich water is then precipitated as snow to form glacier ice and ice caps. The more severe the glaciation, the larger the ice caps, and the greater the $\delta^{18} \mathrm{O}: \delta^{16} \mathrm{O}$ ratio in the ocean. During non-glacial periods, the $\delta^{16} \mathrm{O}$ has the opportunity to return to the oceans through rainfall and melt-water (see discussion in Railsback, 1990). It is thought that after the demise of the end Ordovician glaciation, little or no ice persisted into the early Silurian (see discussion later in this chapter). Most authors therefore suggest an alternative explanation for the Silurian stable oxygen isotope record.

If oxygen stable isotopes are interpreted as a palaeosalinity record, the major controls on $\delta^{18} \mathrm{O} / \delta^{16} \mathrm{O}$ levels were fresh water input and rates of evaporation (Wenzel and Joachimski 1996, Samtleben et al. 1996). It is suggested that during a wet/cool climate (Text-fig. 5.3), the input of fresh water from high precipitation, introduced more $\delta^{16} \mathrm{O}$ into the ocean, effectively diluting the $\delta^{18} \mathrm{O}$ and giving low values. During a warm dry climate, much of the $\delta^{16} \mathrm{O}$ rich freshwater input would have stopped and $\delta^{16} \mathrm{O}$ rich water vapour would have evaporated out of the ocean system. Samtleben et al. (1996, p. 289) do not clearly define a sink for $\delta^{16} \mathrm{O}$ rich freshwater (such as polar ice or freshwater lakes). Wenzel and Joachimski (1996 p.157) suggest that a signal opposite to that generated by storing $\delta^{16} \mathrm{O}$ rich freshwater in the ice caps may be generated by $\delta^{18} \mathrm{O}$ rich saltwater storage in the deep water of a salinity stratified ocean during a warm stable climate. This would give an artificially high level of $\delta^{16} \mathrm{O}$ rich water on the shelf. Wenzel and Joachimski (1996) suggest that this storage effect would not occur in a well-circulated ocean. The sedimentary record can be regarded as a measure of the oceanic $\delta^{18} \mathrm{O} / \delta^{16} \mathrm{O}$ levels on the shelf, along with a signal from all the diagenetic depositional carbonate phases in the sample (Heath et al. 1998). 


\section{Wet/cool climate}

\section{Dry/warm climate}
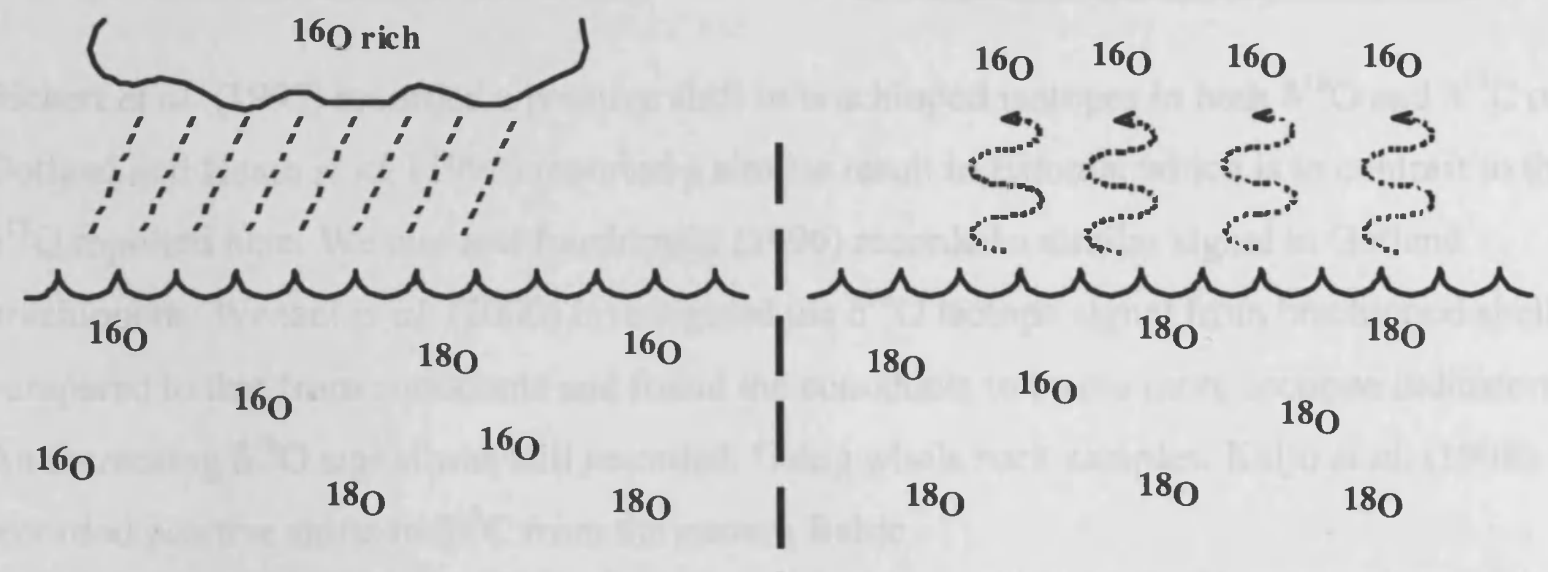

80

$1_{0} \quad 16_{0} \quad 16_{0} \quad 16_{0}$

A wet climate means $\delta^{16} \mathrm{O}$ rich fresh water is added into the system and incorporated into the sediment. The sediment contain relatively high levels of $\delta^{16} \mathrm{O}$.

A dry climate means $\delta^{16} \mathrm{O}$ evaporates out of the system and not incorporated into the sediment. The sediment cont ains relatively low levels of $\delta^{16} \mathrm{O}$.

TEXT-FIG. 5.3. Cartoon showing the relative levels of $\delta^{16} \mathrm{O}$ incorporation into oceanic sediment, in a wet/cool and dry/warm climate.

The rise in $\delta^{13} \mathrm{C}$ may simply reflect the rise in the occurrence of limestones (which rapidly develop into more continuous and thicker units higher in the Upper Visby Beds). The limestones would have had a much greater bioclastic input. If the bioclastic sediment were partly from organisms which constructed calcite shells in areas that were characterised by the $\delta^{13} \mathrm{C}$ rich ocean and these were then transported further out onto the shelf into the area of Lusklint 1 , the sedimentary record would be altered accordingly. Equally, $\delta^{12} \mathrm{C}$ rich organic debris may have been winnowed out of the bioclastic limestones, which may therefore give a false indication of the buried carbon.

The stable oxygen isotope record suggests that the changes in precipitation and evaporation across the Ireviken Event are very minor and are only picked up in the sedimentary record as a more variable isotope pattern in the Upper Visby Beds. It may also imply there was little change in deepwater circulation and storage effects across the Ireviken Event (Wenzel and Joachimski 1996).

It is difficult to compare Corfield and Siveters' isotope data to other studies because nothing has been published on the same scale. Many other studies use brachiopod shells to derive isotope values which, in recent years has been brought into question because of the influence 
of physiological processes and diagenetic alteration on the climatic signal (see discussion in Newton 1997).

Bickert et al. (1997) recorded a positive shift in brachiopod isotopes in both $\delta^{18} \mathrm{O}$ and $\delta^{13} \mathrm{C}$ on Gotland and Heath et al. (1998) reported a similar result in Estonia, which is in contrast to the $\delta^{18} \mathrm{O}$ reported here. Wenzel and Joachimski (1996) recorded a similar signal in Gotland brachiopods. Wenzel et al. (2000) investigated the $\delta^{18} \mathrm{O}$ isotope signal from brachiopod shells compared to that from conodonts and found the conodonts to be the more accurate indicators. An increasing $\delta^{18} \mathrm{O}$ signal was still recorded. Using whole rock samples, Kaljo et al. (1998) recorded positive shifts in $\delta^{13} \mathrm{C}$ from the eastern Baltic.

Little work on Lower Silurian stable isotopes has been done outside the Baltic. One of the few publications is Corfield et al. (1992) on the UK, but samples were only collected as low as the Much Wenlock Limestone Formation, so cannot be compared with these data.

\section{MODELS FOR THE PALAEOZOIC}

Several assumptions have to be made when formulating models to explain the acritarch record in the Palaeozoic. It has to be assumed that the preserved record is an accurate representation of the phytoplankton community. It is reasonable to assume that modern dinoflagellates are analogous to Palaeozoic acritarchs. They have a broadly similar morphology, having for example, similar processes and excystment mechanisms, they are both cyst forming, and acritarchs have a dinoflagellate like, planktonic distribution. Dinoflagellates show no simple cause and effect relationship between environmental factors and morphology; morphology reflects a very complex interplay of factors such as temperature, salinity, nutrient supply and genetics. An equal complexity between acritarch morphology and these factors must therefore be assumed.

If it is assumed dinoflagellates are analogous to acritarchs it is important to know the function of the cyst in modern dinoflagellates. Reviewing opinions at that time, Evitt (1985) suggested that cysts are the resistant housings of hypnozygotes i.e. zygotic cells which are in a nonmotile resting stage after sexual reproduction e.g. during the winter months or during adverse conditions. Cysts have been recorded as the benthic resting stage of the life cycle (Dale 1977). Many acritarchs probably did not produce cysts (only around $15 \%$ of modern dinoflagellates are cyst producing), but I have assumed the preserved record reflects patterns of primary productivity. 
A number of studies that relate modern and Cenozoic dinoflagellates to ecological preferences (such as temperature and nutrient supply) have been published (e.g. Versteegh and Zonneveld 1994, Devillers and de Vernal 2000). The unknowns involved are too great to apply the same principles to the Gotland palynomorphs. Attempts have been made to relate modern dinoflagallates to fossil acritarch species (Dale, 1977), but cannot be applied here because comparable species to the palynomorphs presented here were not used.

The preservation potential throughout the sections is assumed to be the same and the general rate of deposition is assumed to be constant (although it is accepted that marlstones have more potential for compaction than the limestone and therefore represent greater periods of time). The samples processed are assumed to be unbiased, yielding a representative palynomorph population from each level. All these assumptions are difficult to test.

A major assumption made in formulating a model for the Silurian is that changes in atmospheric $\mathrm{CO}_{2}$ result in changes in climate. The relationship between palaeotemperature changes and changes in $\mathrm{CO}_{2}$ level is close for much of the Palaeozoic (Berner 1992). The direction of a cause and effect relationship is difficult to distinguish. A major assumption that is usually made when suggesting a model for climate change is that high atmospheric $\mathrm{CO}_{2}$ levels produce a warm climate. This may not always be the case; Crowley and Baum (1995) suggested that high atmospheric $\mathrm{CO}_{2}$ levels do not necessarily indicate a warm climate, citing the Late Ordovician glaciation as an example. They considered that the Gondwana plate configuration at that time (which was at a tangent to the South Pole) created a situation where a glaciation occurred during a period of high atmospheric $\mathrm{CO}_{2}$ levels. This was probably coupled with other factors such as changes in ocean circulation. The glaciation under these conditions was short lived and such an event may be unlikely under most circumstances.

\section{Extinction mechanisms}

Ever since Alvarez et al. (1980), published their theory of an extraterrestrial cause for the Cretaceous-Tertiary (K/T) mass extinction, a bolide impact has been a popular mass extinction scenario. The evidence for an impact at the $\mathrm{K} / \mathrm{T}$ boundary (and perhaps at some other extinction events (Becker et al. 2001)) is strong, but it is difficult to implicate an impact at the Llandovery/Wenlock boundary. There are no documented impact structures and there is no chemical evidence (such as an iridium anomaly) for an impact at the Ireviken Event.

It has been established that eruption of voluminous flood basalts is coincident with a number extinction events, for example at the Cretaceous/Tertiary and Permian/ Triassic boundaries 
(Kerr 2000). This is often cited as a major causal mechanism for extinctions. There is no evidence for similar occurrences in the Silurian.

There is good evidence for glaciation in the early Silurian (Hambrey 1985, Grahn and Caputo 1992, Caputo 1998). Unfortunately, accurate dating of the glacial events is notoriously problematic. There are glacial deposits of suggested latest Llandovery and earliest Wenlock age (Grahn and Caputo 1992) but the date of these can only be approximately constrained by evidence of the age of overlying strata. The build-up of ice at this time may have caused a small sea level fall, but probably not of enough magnitude to cause an extinction event. At the Llandovery/Wenlock boundary, the ice levels would have been minor (confined to South America), compared to those seen late Ordovician and early Llandovery, when the ice was more widespread covering West Africa, South Africa, the Arabian Peninsula, eastern North America, west and central South America and Europe (Hambrey 1985).

Gas hydrates have been implicated in climate change theories by a number of authors (see discussion in Weissert 2000). The hypothesis involves sudden release of methane from sedimentary gas hydrate deposits, initiated by a warming of the deep ocean (which could be argued to have occurred in an S-state). Methane escape would be reflected by a negative carbon isotope anomaly, which would return to a higher level than the original values as the sedimentary processes responded by burying more organic carbon. The carbon isotope data recorded from Lusklint 1 (Corfield and Siviter pers. com.) show a gradually increasing positive carbon-isotope anomaly; this suggests methane release was unlikely at this time.

Major tectonic changes were happening globally at the time of the Ireviken Event and throughout the whole Silurian. Although the exact timing is controversial, the early Silurian saw the collision of Baltica and Avalonia with Laurentia (Torsvik et al. 1990). The tectonic changes must have had an effect on local sea level, but it is unclear what effect these changes had on the palynomorphs at the Ireviken Event. The effects would have been highly dependent on the timing of the collision and the speed at which it took place, both of which are unclear. The consequences would have been wide ranging altering currents, nutrient supplies and local weather patterns.

All the above factors appear inadequate or insufficiently concentrated to cause the Ireviken Event. There remain two models cited in recent literature: sea level change (Loydell 1998) and the transition from a $P$ to an $S$ state (Jeppsson 1997). These mechanisms are reviewed below. 


\section{Sea level change}

Before 1990 (when Jeppsson published his $P$ and $S$ model), sea level change was the most cited explanation proposed for the faunal and floral changes observed in the Silurian. Presently, many authors (e.g. Johnson et al. 1991, 1996, Loydell 1994, 1998) still regard sea level change as the main causal mechanism for the extinctions recorded. Not all the interpretations of the magnitude and direction of sea level change agree, especially at the Llandovery/Wenlock boundary (Text-fig. 5.4).

The sea level curve signals are highly dependent on the method used to calculate them and the amount of data available to the authors. For example, Johnson et al. (1991) published a generalised sea level curve for the Silurian showing a gradual sea level fall across the Llandovery/Wenlock boundary. In the light of a larger database (Johnson 1996) this pattern was revised to show a marked fall in the late Llandovery and a rise in the early Wenlock.

Unfortunately, one of the more detailed curves must be treated with caution. Loydell (1998) constructed his curve on the basis of graptolite diversity and sedimentary carbon content, there are a number of problems with both lines of evidence. Firstly, it is unclear whether the graptolites themselves have been used when the inshore and outer shelf environments have been defined. If they have, the argument becomes circular (Jeppsson and Aldridge 2001). Factors other than sea level that may have affected graptolite diversity were not considered. These factors include nutrient supply, water temperature, oceanic circulation, graptolite food supply and predator-prey relationships (Jeppsson and Aldridge 2000, p. 1137, Jeppsson and Aldridge 2001). The absence of any direct living relatives of the graptolites means there is no direct evidence to suggest their ecological preferences. Loydell's assertion that sea level was the primary control on graptolite distribution may be correct, but it could equally be argued that any of the other factors mentioned above could have been a more dominant influence. The curve also relies on the preservation potential, the sedimentation rate and the level of bioturbation remaining constant at different levels. Loydell (2001) cited numerous authors who have reported 'decades of consistent observations' on graptolite diversity and sea level, but as Jeppsson and Aldridge (2001) point out, we have to assume that all the datasets are statistically reliable and that different sample sizes have been taken into account. This is not often the case.

Text-fig. 5.4 graphically illustrates that there are major mismatches between Loydell's (1998) curve and that of other authors. Loydell attributed these differences to the inaccurate dating 


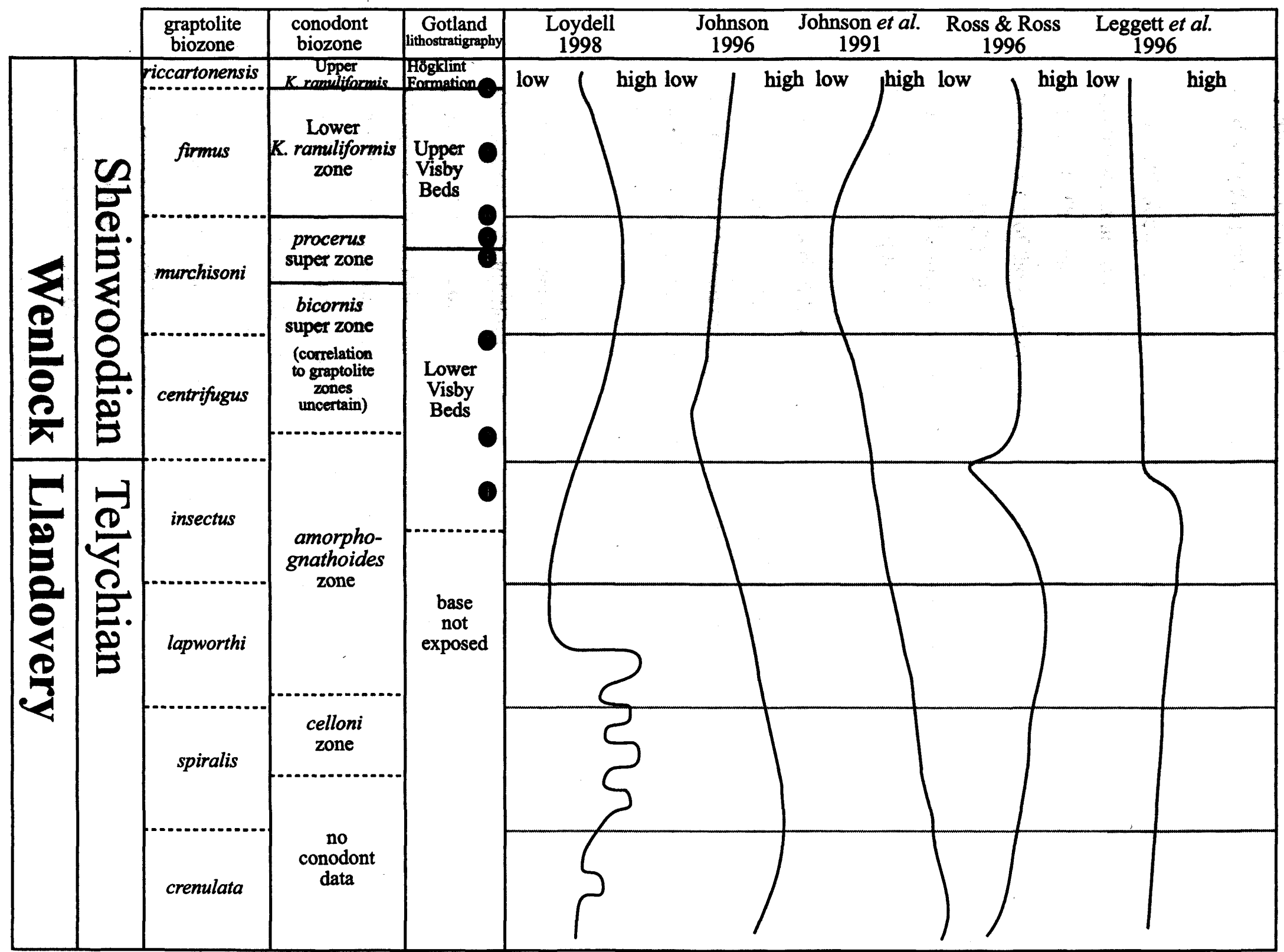

TEXT-FIG 5.4. Diagram showing a comparison of the commonly used sea level curves for the lower Silurian. The graptolite zones identified from the UK (Loydell 1998, Mabillard and Aldridge 1985), the conodont zones from Gotland (datum levels marked with a black circle) (Jeppsson 1997) and the Gotland lithostratigraphy are shown. Dashed lines are used for the boundaries between the graptolite zones because their correlation to the stages are unknown. Dashed lines are used in the conodont zonation where their position relative to the Gotland lithostratigraphy is unknown. The correlation between the conodont biozones and graptolite biozones is taken from Loydell et al. (1998). 
and correlation of graptolites used in other curves, some of which have subsequently been reassessed by Loydell (1992, Loydell et al. 1998). As Loydell (2001, p. 731) suggested, the differences in the sea level curves may be resolved when more precise dating using graptolites is conducted on the datasets used in other studies. Equally these differences in the curves may be due to the problems encountered when graptolites are used as sea level indicators.

As a control on his sea level interpretation, Loydell (1998) used increased carbon content of sediments as an indicator of transgressive sequences, but again this is not solely dependent on sea level. The amount of organic carbon fixed in sediments is greatly influenced by oxygenation of the sea floor and nutrient availability (Hay 1988). Sea floor oxygenation is in turn controlled by dissolved oxygen in the water and oceanic circulation of the bottom waters. Nutrient availability controls the level of photosynthesis and the amount of carbon fixation from the atmosphere.

Burial histories of Silurian coastal topographies have been used to determine sea level changes (Johnson et al. 1998). This provides another potential independent test for the sea level curve produced by Loydell (1998). Unfortunately this method involves biostratigraphic correlation of Silurian rocky shorelines, which is notoriously difficult (Jeppsson and Aldridge 2001).

The lithological record provides a possible source of information about sea level variations. On Gotland, the lithology of the late Llandovery is dominated by calcareous marls, which gradually become dominated by argillaceous limestones in the early Wenlock. It is generally accepted that the patch reef formation that occurred in the early to mid Wenlock represented a shallow shelf environment (Watts and Riding 2000). A somewhat simplistic interpretation is that the change in lithology reflects a gradual relative drop in water depth where the increasingly shallow water created a reef community niche.

A potentially highly sensitive and detailed record of sea level variations might be recorded in the acritarchs. Interpreting relative water depths from acritarchs is difficult, as sea level is one of probably many factors that influenced the palynomorph record. Working on Ludlow material, Dorning (1981b) produced a summary of the palynomorph assemblages likely to be recorded at different proximities to the shoreline. Generalised nearshore, offshore and deepwater palynomorph communities were described. The usefulness of these generalisations in the present study is limited, as the assemblages analysed all fall within the offshore category. Using Palaeozoic material from Libya, Al-Ameri (1983) produced a generalised diagram 
CHAPTER 5

(similar to that of Dorning (1981b)) where six acritarch zones related to water depth were identified. No specific depth information was suggested and most of the acritarchs discussed by $\mathrm{Al}-\mathrm{Ameri}$ and in the present study are within his Zone 4.

Le Hérissé and Gourvennec (1995) suggested that Deunffia-Domasia dominated assemblages, such as those reported for the Llandovery/Wenlock boundary in the Welsh Borderland (Hill \& Dorning 1984), are indicative of outer-shelf environments. This interpretation is difficult to apply to Gotland; the occurrences of Deunffia are very rare and the relative abundance of Domasia varies little between samples. If Le Hérissé and Gourvennec (1995) are correct, the relative stasis of Deunffia-Domasia numbers across the Llandovery/Wenlock boundary on Gotland could be used to suggest that sea level change was small. Richardson and Rasul (1990) suggested that an inshore index calculation could be used to estimate shore proximity/water depth. The concept relied on the acanthomorph/netromorph etc. classification, the groupings of which were then used as a proxy for environment. This assumption is flawed. Richardson and Rasul (1990) used the groups to suggest specific environmental conditions, but the groups include very diverse species, with probably very different environmental tolerances.

It is very likely that sea level change was an important factor in the Silurian, and lithological and palaeontological changes support this view. Problems arise when sea level is invoked as the only cause of the biotic turnover. If sea level change were the only mechanism affecting the biota in the Silurian it must be assumed that either the climate was in steady state or that climate change did occur, but had no influence over the biota. Given the massive climate change that has taken place in the last few million years (even the last ten thousand years) it is difficult to believe that the climate was stable for the whole of the lower Silurian. It appears that the proponents of a single cause and effect sea level hypothesis are suggesting that the biota was unresponsive to climate change during the Silurian. This is difficult to believe.

\section{$P$ and $S$ cyclicity}

$\mathrm{P}$ and $\mathrm{S}$ cyclicity was first proposed by Jeppsson (1990) as an explanation of biotic and sedimentological changes throughout the Silurian (see Jeppsson 1998 for a summary).

According to the model, (Text-fig. 5.5) P-states such as that occurring in the late Llandovery were characterised by a wet climate, with high runoff and high sediment influx into the ocean; marls were deposited on the shelf. The deep oceans were well mixed due to the heating and 
upwelling in the tropics of dense cold water currents (which supply nutrients). The cool temperatures caused a slight thermal contraction of the oceans and consequent regression.

S-states such as that envisaged for the early Wenlock were characterised by a dry climate with low runoff and high evaporation. The sediment influx into the oceans stopped, the water became clear and limestones developed on the shelf. The cold dense water current switched off and salinity stratification developed. The higher temperatures would have caused thermal expansion of the oceans and a slight transgression.

At the transition between the $P$ and S-states (Text-fig. 5.6) the ocean reached $\mathrm{CO}_{2}$ saturation point and changed from being a carbon sink to a carbon source (Jeppsson 1990). The increased $\mathrm{CO}_{2}$ pumped into the atmosphere is thought to have been one of the main warming mechanisms.

The $\mathrm{P}$ and $\mathrm{S}$ model predicts a high rate of vertical advection of nutrients to the surface waters and increased weathering in the P-state and a stratified ocean in the S-state; this predicts a high planktonic production in the P-state and low in the S-state (only a tenth of that in the Pstate (Jeppsson 1990)).

The acritarch record at Lusklint 1 and Lickerhamn 2 shows no unequivocal evidence for the existence of $\mathbf{P}$ and $\mathbf{S}$ cycles, but merely that this was a time of turnover associated with probable climatic and sea level changes. Although the P and S model does not successfully explain some of the patterns observed in this study, it is the best model available that encompasses the complexities of sea level change and climate variability. The predictive power of the model can only improve as the more speculative parts are constrained.

The mixed and stratified ocean and wet/cool and dry/warm climate scenarios discussed above for stable carbon and oxygen isotopes could be regarded as a proxy for the $\mathrm{P}$ and $\mathrm{S}$ climate states respectively, of Jeppsson (1990) (see discussion in Wenzel and Joachimski 1996). The complex interplay of factors that control isotope composition in the sediment means it is difficult to suggest whether the predictions of the $\mathrm{P}$ and $\mathrm{S}$ model are correct. If oceanic circulation was the dominant factor, the model predicts lower relative values of $\delta^{13} \mathrm{C}$ in the Sstate of the Upper Visby Beds where we see the opposite in a rising trend, implying a bettercirculated ocean. Equally productivity and fractionation of $\delta^{12} \mathrm{C}$ into the acritarchs could have been more dominant. The model predicts a decrease in productivity in the Upper Visby Beds, which could generate the rising signal observed, due to lower level of removal of $\delta^{12} \mathrm{C}$. If a 


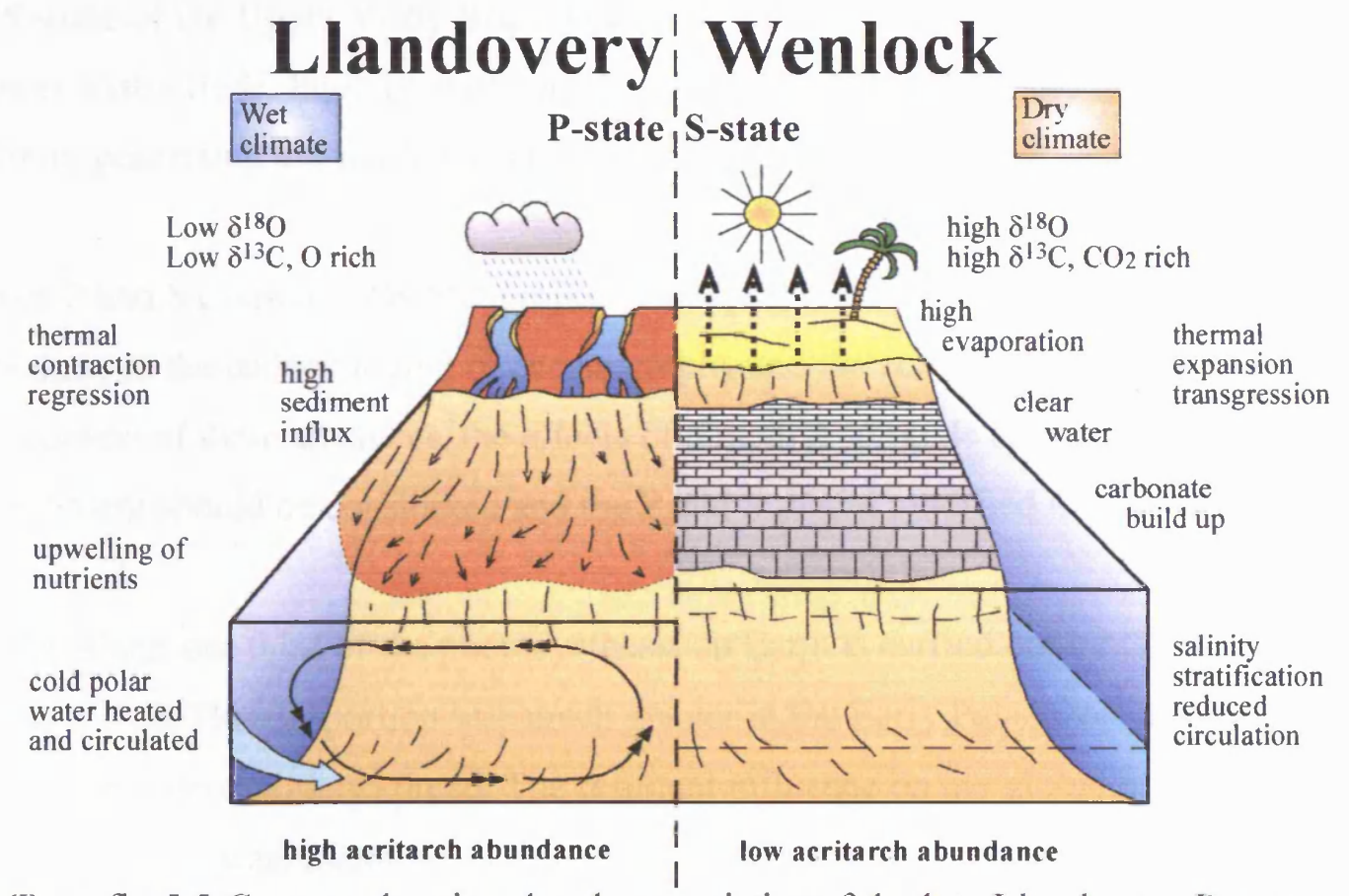

Text-fig.5.5. Cartoon showing the characteristics of the late Llandovery $\mathrm{P}$-state and the early Wenlock S-state (after Jeppsson 1990).

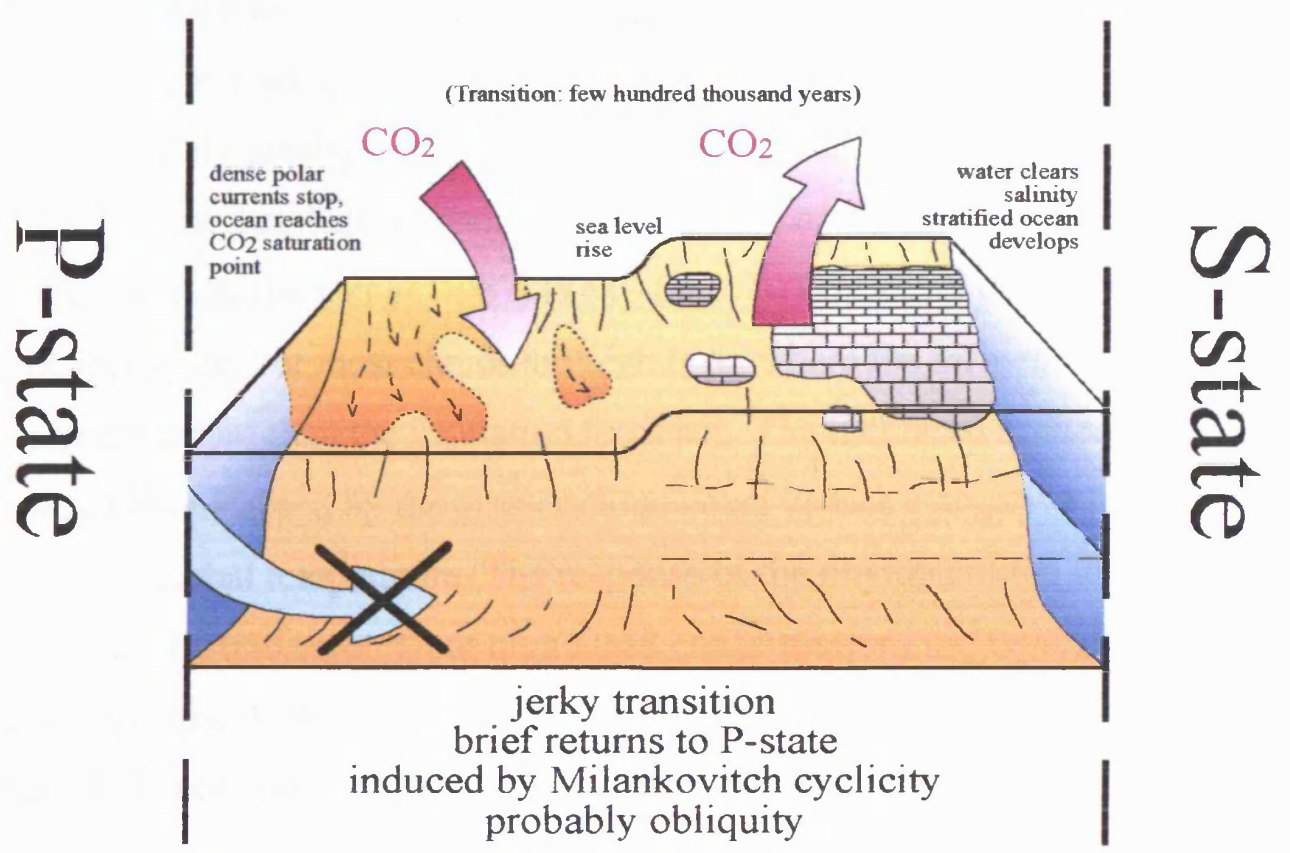

Text-fig. 5.6. Cartoon showing the characteristics of the transition between the late Llandovery P-state and the early Wenlock S-state (after Jeppsson 1990). 
change in temperature and/or salinity took place, the model predicts increased levels of $\delta^{18} \mathrm{O}$ in S-state of the Upper Visby Beds, where we see very little change from the record of the Lower Visby Beds. Equally, there may have been little or no change in temperature and salinity generating the stable signal observed.

Since P and S cyclicity was first proposed (Jeppsson 1990), there have been a number of advances in the understanding of oceanography and the ecology of modern phytoplankton. In the context of these advances, the effects of dimethyl sulphide emissions and of iron enrichment should be considered and the $P$ and $S$ model modified in response.

Today about one third of the photosynthesis on Earth is carried out by the phytoplankton (King 1975). This proportion was much greater in the Early Palaeozoic as land plants were primitive and not widely spread. The resultant influence on the global biosphere of oceanic photosynthesis was, therefore, considerably greater than it is today.

Many modern planktonic algae generate dimethyl sulphide (DMS) from a dimethylsulphonium propionate (DMSP) precursor, produced in osmoregulation, during grazing, autolysis and bacterial or viral attack. Coccoliths have been recorded as having the highest rate of DMS excretion per unit biomass at the present day (Charlson et al. 1987, p. 656), but it is widely accepted that dinoflagellate DMS production is important in modern oceans and possibly greatly underestimated (Steinke et al. 2002). DMS oxidises in the atmosphere to form sulphate aerosols, a major source of cloud condensation nuclei (CCN) over the oceans (Charlson et al. 1987) (Text-fig 5.7). Low-level clouds generally have an insulating influence, but most clouds are high level where the influence on planetary albedo is much more dominant than the insulation feedback. The increased scattering and absorbing of the sun's radiation caused by the greater cloud cover causes a negative feedback response decreasing the global temperature. The response of the phytoplankton to the temperature change is not fully understood, but high DMS concentrations are typically observed in warm surface waters (Idso 1992). Therefore, in a high productivity P-state there would be feedback to prolong that cool climate.

Mixing in the water column is extremely important in the conversion of DMSP to DMS (Simó \& Pedrós-Alió 1999). Minimum yield of DMS is achieved at a mixing depth of 15$20 \mathrm{~m}$, higher yields are recorded at deeper mixing layer depths and near $100 \%$ conversion at extremely shallow depths of circulation. If DMS production is introduced as a major factor in the $\mathrm{P}$ and $\mathrm{S}$ model, the depth of vertical mixing will be one of the dominant influences on its 


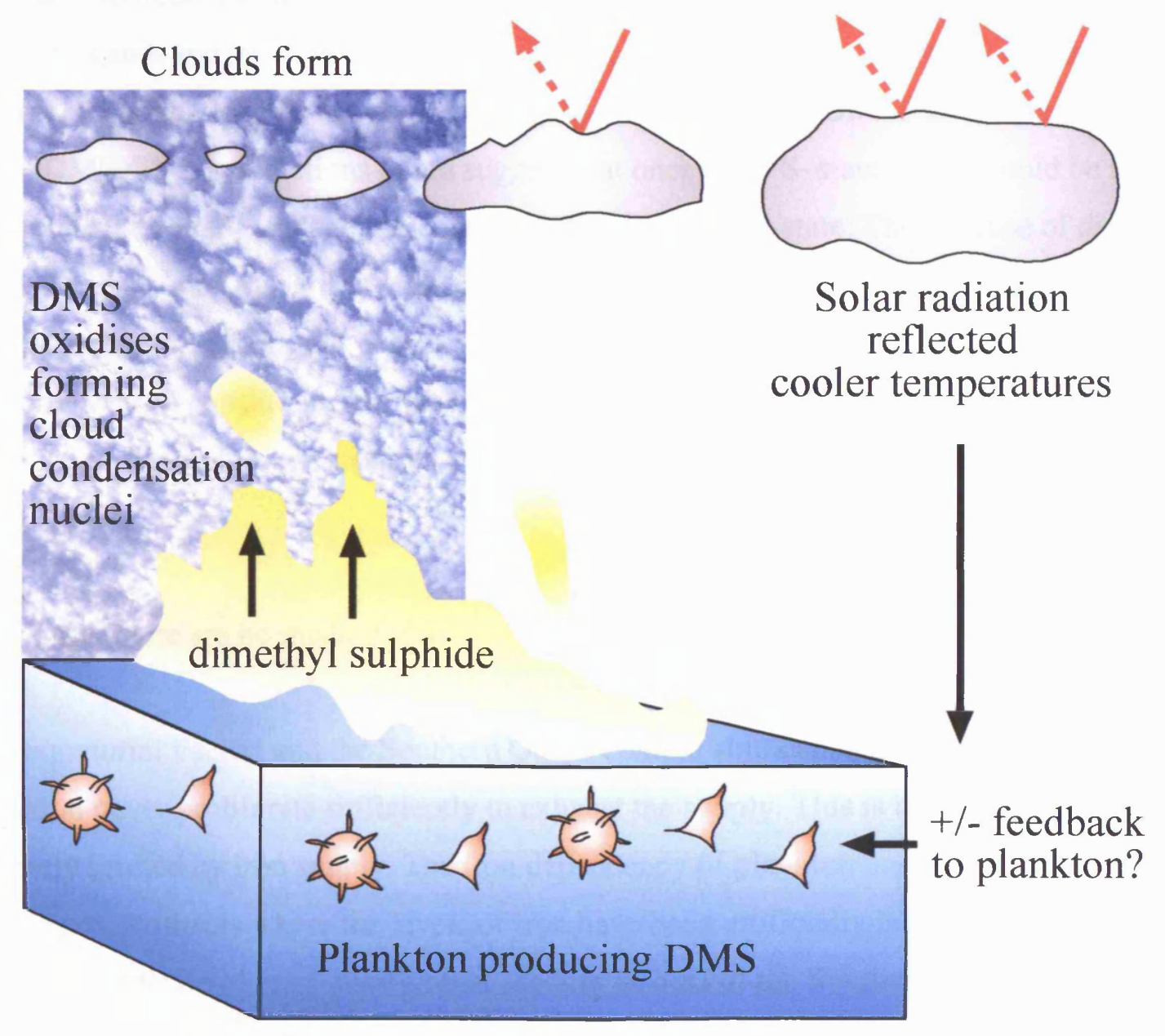

Text-fig. 5.7 Cartoon showing the relationship between DMS production in plankton and increased cloud cover. 
production and by inference, on global temperature.

Simó \& Pedrós-Alió (1999) suggested that in winter and early spring when the climate is cooler (perhaps analogous to P-state), mixed waters are characterised by blooms of large diatoms. These have a large biomass, but produce little DMS as most large diatoms produce little DMSP. The stratification that occurs in the late spring (perhaps analogous to an S-state) lowers the phytoplankton biomass and favours small flagellates, coccolithophores and dinoflagellates, which all have a strong DMS producing potential. The food web seems to alternate between the two states. During the mixed waters of winter and spring, the primary producers sink and swim in and out of the photic zone, but during the stratified late spring an internal recycling loop develops producing a faster turnover of DMSP and, after a short lagtime, DMS. These predictions could suggest that once in an S-state, there would be a strong (biologically driven) tendency to change back to a cooler P-state. The absence of diatoms in the Palaeozoic may mean that these conclusions are irrelevant. The response of dinoflagellates to similar conditions has not been investigated, but could be quite different and may be more important when considering acritarchs. No changes in size distribution between large and small acritarch species (as reported by Simó and Pedrós-Alió (1999) for diatoms) are reported here.

Currently, there are no methods for testing the level of DMS in the Palaeozoic ocean.

The equatorial Pacific and the Southern Ocean contain abundant essential nutrients, but plankton never proliferate sufficiently to exhaust the supply. This is because productivity is severely limited by iron supply. The iron dependency of plankton has been illustrated in seeding experiments where the levels of iron have been artificially increased in particular areas. In 2000, Boyd et al. showed that seeding an area of the Southern Ocean with iron stimulated the phytoplankton to produce an elevated draw-down of $\mathrm{CO}_{2}$ from the atmosphere, increase the utilization of nutrients and elevate DMS levels after only 13 days. Others (e.g. Turner et al. 1996), have shown that experiments which mimic natural iron enrichment increase DMS production by a factor of 3.5. A dramatic illustration of the influence of iron enrichment can be seen in Text-fig. 5.8., which shows a chlorophyll rich plume stimulated by iron enrichment (Martin et al. 1994).

If the $\mathrm{P}$ and $\mathrm{S}$ climate model is correct, it would be expected that during the wet climate of a P-state there would be little opportunity for wind blown dust to enter the atmosphere.

Elevated iron levels would only be observed around the mouths of rivers and would be a very 
localised phenomenon. The alluvial iron would be quickly removed from the ocean system in various oxidation reactions (Cranfield 1988) and would be buried in the rapidly accumulating sediment; much of the iron would be attached to clay particles, which tend to flocculate in brackish conditions. In modern oceans more than $90 \%$ of fluvial sediment (containing most of the iron) is deposited in coastal areas and on continental margins; of the majority of elements in the sediment, only $20 \%$ are suspended and carried out to sea (Lisitzin 1996).

In the open ocean sediments, aeolian and glacial sources contribute $3 \cdot 1$ billion tons to the world's oceans every 1000 years, but fluviogenic sources supply only 1.7 billion tons every 1000 years (Lisitzin 1996). In the $P$ and $S$ model the arid S-state would provide a source of widespread airborne iron-rich dust (as is exemplified by the iron fertilization stretching west into the Atlantic Ocean and into the Mediterranean from the Sahara desert (Text-fig.5.9; Dulac et al. 1996)). The major source and sink areas are shown in Text-fig. 5.10 (Lisitzin 1996). It should also be noted that modern day aeolian dust is mainly concentrated between the tropics, the same latitude as that suggested for the Baltic in the early Wenlock (Torsvik et al. 1990). Tappan (1986) emphasized the importance of terrestrial weathering as a plankton nutrient source, to the extent that land plant evolution has had a massive influence on planktonic evolution through the nutrient retention of land plant biomass; the nutrients would otherwise have been available to be recycled back into the oceans. Several studies have reported an order of magnitude decrease in atmospheric dust loads during the transition between arid glacial environments and wet interglacial environments (see Idso 1992 for a summary). The decrease in iron available to the phytoplankton carried in atmospheric dust during interglacial conditions is suggested to greatly reduce their planktonic productivity rates.

It could be argued that the Silurian plankton of the Baltic were not iron limited. This may be the case, but the location of the Baltic near to the equator means that the plankton were likely to have behaved as they do today in the equatorial Pacific and the Southern Ocean.

There are currently no methods for estimating iron levels of the Palaeozoic ocean.

The gradual acritarch species originations that occur through most of the Ireviken Event may be a reflection of gradually increasing available iron during the transition from a $P$ to an $S$ state. The number of acritarchs per gram of sediment shows no increasing or decreasing trend through the sections. The warmer more arid S-state would have provided a larger source of iron, which in turn should increase the phytoplankton biomass and induce a negative feedback 


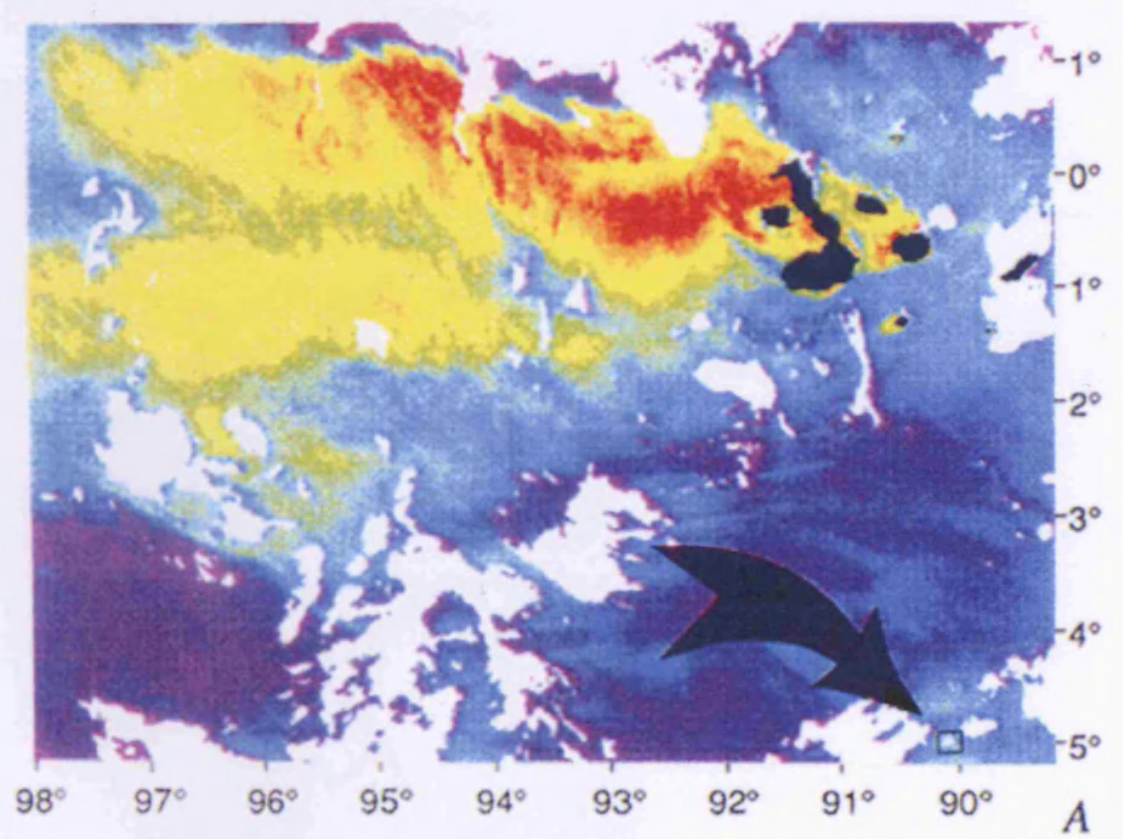

TEXT-FIG. 5.8. False-colour image from the Coastal Zone Colour Scanner on the Nimbus 7 satellite, October 1983. This image indicates the chlorophyll-rich plume extending west from the Galapagos Islands after iron seeding(red colour indicates higher chlorophyll concentrations). Fig. 1. A, from Martin el al.1994.

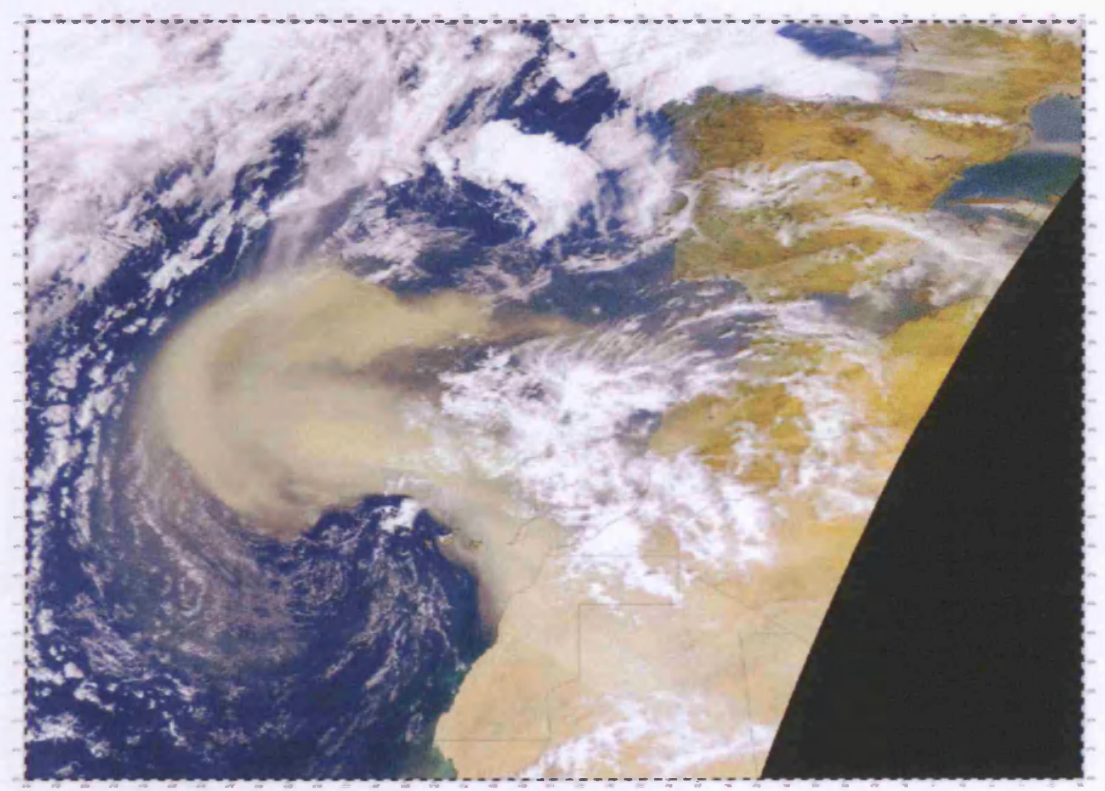

TEXT-FIG. 5.9. Satellite image showing a massive sandstorm blowing off north-western Africa, enveloping hundreds of thousands of square $\mathrm{km}$ of the eastern Atlantic Ocean. This storm, recorded on the 26th of February 2000, by the Sea WiFS project stretches more than $1600 \mathrm{~km}$ out to sea. (Source: Sea WiFs project, NASA (http://seawifs.gsfc.nasa.gov)) 


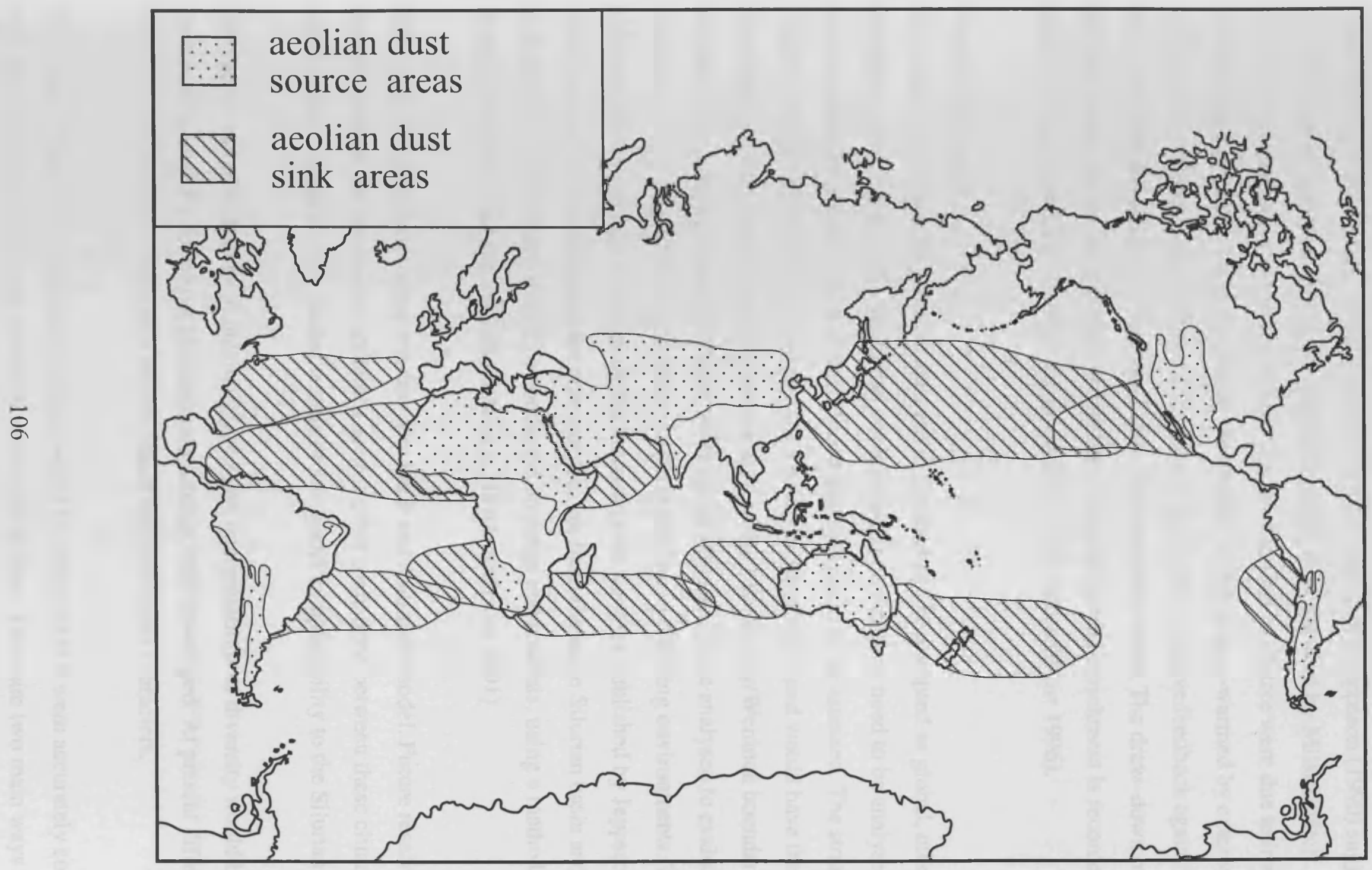

TEXT-FIG. 5.10. Map showing the large extent of the planet affected by deposition of wind blown dust. After Lisitzin (1996). 
from increased DMS production (in contrast to the predictions made by Simó and Pedrós-Alió (1999) for an increased biomass of diatoms). This would cause indirect cooling (Turner $e$ al. 1996) and a possible return to the cooler P-state. The Jeppsson model does not predict this. The influence of iron induced DMS negative feedback may be important in explaining the transition from P to S-state, which is thought to have been jerky. Jeppsson (1990) suggested the brief retums to $P$-state during the transition period were induced by Milankovitch cyclicity. An alternative explanation is that the brief returns to P-state were due to iron induced DMS negative feedback cooling the climate, which was re-warmed by external forcing from increasing atmospheric $\mathrm{CO}_{2}$ only to induce the negative feedback again, until a threshold level was reached where the S-state could be maintained. The draw-down of $\mathrm{CO}_{2}$ into the oceans during increased photosynthesis induced by iron enrichment is recorded as only having a small negative effect on atmospheric $\mathrm{CO}_{2}$ values (Frost 1996).

\section{FUTURE RESEARCH}

Before the phytoplankton patterns observed in Gotland can be accepted as global, other localities, which have similar depth and environmental parameters, need to be analysed. This would enable the provincialism of the Silurian phytoplankton to be assessed. The stratotype at Hughley Brook (Shropshire) would provide a suitable comparison and would have the added advantage of better constraining the precise level of the Llandovery/Wenlock boundary on Gotland. The patterns present in deeper water facies also need to be analysed to evaluate the variability of the palynomorph responses to the extinction in differing environments. To maintain the consistency of this study the Estonian core samples published by Jeppsson (1993), could be used (although the core samples are from the same Silurian basin and facies as Gotland). Further work should be conducted on range end analysis, using a method which is more inclusive of all the available data (e.g. Hayek and Bura 2001)

The acritarchs provide a unique window into the $P$ and $S$ climate model. Future research should compare the patterns of acritarchs seen at other transitions between these climate states, which would provide further testing of the model's applicability to the Silurian.

The usefulness of acritarchs in biostratigraphy and interpretations of diversity would be greatly enhanced if a definitive classification scheme were developed. At present different authors place different importance on individual morphological characters.

The value of the data collected on Gotland would be enhanced if it were accurately correlated with the Llandovery/Wenlock boundary at the type section. There are two main ways this 
might be achieved: a statistical reassessment of the palynological samples collected from the Llandovery/Wenlock boundary type section by Mabillard and Aldridge (1985), or through a magnetic susceptibility survey. Palynological correlation is problematic due to regional assemblage variations, but magnetic susceptibility correlations have successfully been used on Lower Devonian sections (Ellwood et al. 2001). Accurate correlation (independent of the conodont zonation) would be useful in comparing Lusklint 1 with Lickershamn 2. 
AL-AMERI, T. K. 1983. Acid-resistant microfossils used in the determination of Palaeozoic palacoenvironments in Libya. Palaeogeography, Palaeoclimatology, Palaeoecology, 44, $103-116$.

AIDRIDGE, R. J. 1976. Comparison of macrofossil communities and conodont distribution in the British Silurian. In BARNES, C. R. (ed). Conodont Paleoecology, 91-104, The Geological Association of Canada [Special paper], 15.

JEPPSSON, L. \& DORNING, K. J. 1993. Early Silurian oceanic episodes and events. Journal of the Geological Society, London, 150, 501-513.

AlVAREZ, L. W., AlvaREZ, W., AsARo, F. \& Michel, H. V. 1980. Extraterrestrial cause for the Cretaceous-Tertiary extinction. Science, 208, 1095-1108.

BARSS, M. S. \& WILLAMS, G. L. 1973. Palynology and nannofossil processing techniques. Geological Survey of Canada, 73, 1-25.

Bassett, M. G., KalJo, D. \& TelleR, L. 1989. The Baltic region. In HollaND, C. H. \& BASSETT, M. G. (eds), A global standard for the Silurian System. 1-325. National Museum of Wales, Geological Series No. 9, Cardiff.

BeCker, L., POREDA, R. J., HuNT, A. G., BunCH, T. E. \& RAMPINO, M. 2001. Impact event at the Permian-Triassic boundary: evidence from extraterrestrial noble gases in fullerenes. Science, 291, 1530-1533.

BERNER, R. A. 1992. Palaeo $-\mathrm{CO}_{2}$ and climate. Nature, 358, 114.

Bickert, T., PÄtzold, J., SAMtleben, C. \& MuNNECKE, A. 1997. Paleoenvironmental changes in the Silurian indicated by stable isotopes in brachiopod shells from Gotland, Sweden. Geochimica et Cosmochimica Acta, 61, 2717-2730.

BOTTING, J. P. 1999. The ecological effects of volcanic ash-fall in the marine Ordovician of Central Wales. Acta Universitatis Carolinae - Geologica, 43 (1/2), 499-502. Boyd, P. W., Watson, A. J., LAw, C. S., Abraham, E. R., Trull, T., MuRdoch, R., BakKer, D. C. E., Bowie, A. R., Buesseler, K. O., Chang, H., CharetTe, M., CroOt, P., Downing, K., Frew, R., Gall, M., HAdField, M., Hall, J., HARVEY, M., JAMESON, G., LAROCHE, J., LIDDICOAT, M., LING, R., MALDONOADO, M. T., MCKAY, R. M., Nodder, S., Pickmere, S., Pridmore, R., Rintoul, S., SAFi, K., Sutton, P., StrZePeK, R., TANneberger, K., TURner, S., Waite, A. \& Zeldis, J. 2000. A mesoscale phytoplankton bloom in the polar Southern Ocean stimulated by iron fertilization. Nature, 407, 695-702.

CAPUTO, M. V. 1998. Ordovician-Silurian glaciations and global sea-level changes. In LANDING, E. \& JOHNSON, M. (eds), Silurian cycles: linkages of dynamic stratigraphy with 
atmospheric, oceanic and tectonic changes, New York State Museum Bulletin, 491, 1525.

Charlson, R. J., Lovelock, J. E., ANDReae, M. O. \& WarRen, S. G. 1987. Oceanic phytoplenkton, atmospheric sulphur, cloud albedo and climate. Nature, 326, 655-661. Christinan, T. 1962. Alger. In BOCHER, T. W., LANGE, M. \& SøRENSEN, T. (eds), Botanik (Systematisk Botanik), 172 pp.

COLBATH, G. K. 1985. A comparison of palynological extraction techniques using samples from the Sihurian Bainbridge Formation, Missouri, U.S.A. Review of Palaeobotany and Palynology; 44, 153-164.

- 1986. Abrupt terminal Ordovician extinction in phytoplankton associations, southern Appalachians. Geology, 14, 943-946.

— \& GREFNEL, H. R. 1995. Review of biological affinities of Paleozoic acid-resistant, organic-walled oukaryotic algal microfossils (including "acritarchs"). Review of Palaeobotany and Palynology, 86, 287-314, pls 1-9.

Cookson, I. C. \& EisenACK, A. 1958. Microplankton from Australia and New Guinea Upper Mesozoic sediments. Proceedings from the Royal Society of Victoria, 70, (1), 19-79, pls 1-12.

CORfieId, R. M., Siveter, D. J., CARTLIDGe, J. E. \& MCKERROW, W. S. 1992. Carbon isotope excursion near the Wenlock-Ludlow (Silurian) boundary in the Anglo-Welsh area. Geology, 20, 371-374.

CRAMER, F. H. 1963. Nota provisional sobre la presencia de microplankton y esporomorfas en las rocas sedimentarias del Devónico Inferior en las Montañas Cantábricas. Estudios geologicos, 19, 215-218, pls 1-2.

- 1964a. Some acritarchs from the San Pedro Formation (Gedinnien) of the Cantabric Mountains in Spain. Bulletin de la Société de belge de géologie, de paléontologie et d'hydrologie, 73, (1), 33-38, pls 1-2. 1964b. Microplankton from three Palaeozoic Formations in the Province of León, NWSpain. Leidse Geologische Mededelingen, 30, 253-360, pls 1-2.

1966a. Palynology of Silurian and Devonian rocks in Northwest Spain. Instituto

Geologico y Minero de España, Boletin, 77, 225-286, pls 1-4. 1966b. Hoegispheres and other microfossils incertae sedis of the San Pedro Formation (Siluro-Devonian boundary) near Valporquero, Leon, NW Spain. Instituto Geológico y Minero de España, notas y comunicaciones, 86, 75-94, pls 1-2.

1968. Palynologic microfossils of the Middle Silurian Maplewood shale in New York.

Revue de Micropaléontologie, 11, (2), 61-70, pl. 1. 
REFERENCES

1970. Distribution of selected Silurian acritarchs. An account of the palynostratigraphy

and paleogeography of selected Silurian acritarch taxa. Revista Española de

Micropaleontologia, numero extraordinario, 203 pp., pls 1-23.

— \& DiE, M. DEL C. R. 1972. North America Silurian palynofacies and their spatial

arrangement: Acritarchs. Palaeontographica Abt. B, 138, (5-6), 107-180, pls 31-36.

1974. Silurian acritarchs: distribution and trends. Review of Palaeobotany and

Palynology, 18, 137-154.

1976. Acritarchs from the La Vid Shales (Emsian to lower Couvinian) at Colle,

Le6n, Spain. Palaeontographica Abt B, 158, (1-4), pp. 72-103 pls. 1-7.

\& KJELLSTRÖM, G. 1979. Acritarchs. In JAANUSSON, V., LAUFELD, S. \&

SKOGLUND, R. (eds). Lower Wenlock faunal and floral dynamics-Vattenfallet Section,

Gotland. Sveriges Geologiska Undersökning, serie C, 762, 39-53, figs 16-19.

CRANFIELD, D. E. 1989. Reactive iron in marine sediments. Geochimica et Cosmochimica Acta, 53, 619-632.

CROWLEY, T. J. \& BAUM, S. K. 1995. Reconciling Late Ordovician (440 Ma) glaciation with very high (14X) $\mathrm{CO}_{2}$ levels. Journal of Geophysical Research, 100, (D1), 1093-1101.

DALE, B. 1977. New observations on Peridinium faeroense Paulsen (1905), and classification of small orthoperidinioid dinoflagellates. British Phycological Journal, 12, 241-253.

DAVIS, A. G. 1967. Biological concentration of radiogenic iron in the western Pacific. In ABERG, B. \& HungATE, F. P. (eds), Radioecological concentration processes, pp. 983991, Oxford: Pergamon Press.

DEFLANDRE, G. 1935. Considérations biologique sur les microorganismes d'origine planctonique conservés dans les silex de la craie. Bulletin biologique de la France et de la Belgique, 69, 213-244, pls 5-9.

- 1936. Les flagellés fossiles. Aperçu biologique et paléontologique. Rôle Géologique. Actualités Scientific et Industrielles, 335, 1-97.

1937. Microfossiles des silex cétacés. Deuxième partie. Flagellés incerta sedis. hystrichospæridés. Sarcodinés organismes divers. Annales de Paléontologie, 26, 51-103, pls 11-18.

1945. Microfossiles des calcaires Siluriens de la Montagne Noire. Annales de Paléontologie, 31, 41-75, pls 1-3.

DEUNFF, J. 1954. Sur un microplankton du Dévonien du Canada recélant des types nouveaux d'Hystrichosphaeridés. Comptes rendus des séances de l'Académie des sciences, 239, (17), 1064-1066.

1955. Un microplancton fossile Dévonien a Hystrichosphères du Continent NordAméricain. Bulletin de la microscopie appliquée, sér. 2, 5, (11-12). 138-149, pls 1-4. 
- 1961. Quelques precisions concernant les Hystrichosphaeridées Dévonien du Canada. Compte rendu sommaire des séances de la Société géologique de France, 8, 216-218. — \& BVIr, W. R. 1968. Tunisphaeridium, a new acritarch genus from the Silurian and Devonian. Stanford University Publications, Geological Sciences, 12, (1), 1-13, pl. 1. Deviluars, R. \& DE VeRNAL, A. 2000. Distribution of dinoflagellate cysts in surface sediments of the northern North Atlantic in relation to nutrient content and productivity in surface wators. Marine Geology, 166, 103-124.

DORNavo, K. J. 1981a. Silurian acritarchs from the type Wenlock and Ludlow of Shropshire, England. Review of Palaeobotany and Palynology, 34, 175-203, 3 pls.

1981b. Silurian acritarch distribution in the Ludlovian shelf sea of South Wales and the

Welsh Bordorland. 31-68. In NEALE, J. W. \& BRASIER, M. D. (eds). Microfossils from recent and fossil shelf seas, Ellis Horwood, Chichester.

1983. Palynology and stratigraphy of the Much Wenlock Limestone Formation of

Dudley, central England. Mercian Geologist, 9 (1), 31-40, pls 5-7.

— \& HARVEY, C. 1999. Wenlock cyclicity, palynology and stratigraphy in the Buildwas, Coalbrookdale, and Much Wenlock Limestone formations, Shropshire, England.

Bollettino della Societá Paleontologica Italiana, 38, (2-3), 155-166, 1 pl.

DOWNIE, C. 1959. Hystrichospheres from the Silurian Wenlock Shale of England.

Palaeontology, 2, (1), 56-71, pls 10-12.

1960. Deunffia and Domasia, new genera of hystrichospheres. Micropalaeontology, 6 , 197-202.

1963. 'Hystichospheres' (acritarchs) and spores of the Wenlock Shales (Silurian) of Wenlock, England. Palaeontology, 6, (4), 625-52, pls 91-92.

1973. Observations on the nature of acritarchs. Palaeontology, 16, (2), 239-259, pls 24 27.

- \& SARJEANT, W. A. S. 1963. On the interpretation and status of some hystrichosphere genera. Palaeontology, 6, (1), 83-96.

— EVIT, W. R. \& SARJEANT, W. A. S. 1963. Dinoflagellates, hystrichospheres, and the classification of the acritarchs. Stanford University Publications, Geological Sciences, 7 , (3), 3-16.

— WIILIAMS, G. L. \& SARJEANT, W. A. S. 1961. Classification of fossil microplankton. Nature, 192, 471.

Dulac, F. Mouln, C., Lambert, C. E., Gulllard, F., PoItou, J., Guelle, W., Quetel, C. R., SCHNEIDER, X. \& EZAT, U. 1996. Quantative remote sensing of African dust transport to the Mediterranean. In GUERZONI, S. \& CHESTER, R. The impact of destert dust across the Mediterranean. Kluwer Academic Publishers, Netherlands, 25-49. 
ErsenACx, A. 1938. Hystrichosphaerideen und verwandte Formen im baltischen Silur.

REFERENCES

Zeitschrift fuir Geschiebeforschung und Flachlandsgeolgie, 14,1-30, pls 1-4.

1954. Hystrichosphären aus dem baltischen Gotlandium. Senckenbergiana Lethaea, 34,

(4/6), 205-211, 1 pl.

1955. Chitinozoen, Hystrichosphären und andere Mikrofossilien aus dem Beyrichia-

Kalk. Senckenbergiana Lethaea, 36, (1-2), 157-188, pls 1-5.

1958a. Tasmanites Newton 1875 und Leiosphaeridia n.g. als Gattungen der

Hystrichosphaeriea. Palaeontographica, Abt. A, 110, (1-3), 1-19, pls 1-2.

1958b. Mikroplankton aus dem norddeutschen Apt nebst einigen Bemerkungen über

fossile Dinoflagellaten. Neues Jahrbuch für Geologie und Paläontologie. Abhandlungen,

106, (3), 383-422, pls 21-27.

1959. Neotypen baltischer Silur-Hystrichosphären und neue Arten. Palaeontographica,

Abt. A, 112, (5-6), 193-211, pls 15-17.

1964. Microplankton from three Paleozoic Formations in the Province of León, NW-

Spain. Leidse Geologische Mededelingen, 30, 253-361, pls 1-24.

1965. Mikrofossilien aus dem Silur Gotlands. Hystrichosphären, Problematika. Neues

Jahrbuch für Geologie und Paläontologie. Abhandlungen, 122, (3), 257-274, pls 21-24.

1969. Zur Systematik einger paläozischer Hystrichospären (Acritarcha) des baltischen

Gebietes. Nues Jahrbuch für Geologie und Paläontologie. Abhandlungen, 133, 245-266.

1972. Kritische Bemerkung zur Gattung Pterospermopsis (Chlorophyta,

Prasinophyceae). Neues Jahrbuch für Geologie und Paläontologie. Monatshefte, 596-601.

CRAMER, F. H. \& DIEZ, M. DEL C. R. 1973. Katalog der fossilen Dinoflagellaten,

Hystrichosphären und verwandten Mikrofossilien. Band III Acritarcha 1. Teil. E.

Schweizerbart'sche Verlagsbuchhandlung, Stuttgart, 1104 pp. 1979. Katalog der fossilen Dinoflagellaten, Hystrichosphären und

verwandten Mikrofossilien. Band V. Acritarcha 2. Teil. E. Schweizerbart'sche

Verlagsbuchhandlung, Stuttgart, $529 \mathrm{pp}$.

Eluwood, B. B., CRick, R. E., Garcf́a-AlCalde Fernandez, J. L., Soto, F. M., Truyóls-

Masson,, M., EL-HASSANI, A. \& Kovas, E. J. 2001. Global correlation using magnetic susceptibility data from Lower Devonian rocks. Geology, 29, (7), 583-586.

ETTER, W. 1999. Community analysis. In HARPER, D. A. T. (ed), Numerical palaeobiology computer-based modelling and analysis of fossils and their distributions. 285-360.

Evrr, W. R. 1963. A discussion and proposals concerning fossil dinoflagellates, hystrichospheres, and acritarchs. Proceedings of the National Academy of Science U.S.A., 49, 158-164. 
1985. Sporopollenin dinoflagellate cysts their morphology and interpretation. American Association of Stratigraphic Palynologists Foundation, 333 pp.

Fensomas, R. A., Whllams, G. L., Barss, M. S., Freeman, J. M. \& HiLl, J. M. 1990.

Acritarchs and fossil prasinophytes: an index to genera, species and infraspecific taxa. American Association of Stratigraphic Palynologists Foundation, Contributions Series, 25, $771 \mathrm{pp}$.

FORSTER, M. \& FLENLEY, J. R. 1989. Application of density gradient centrifugation to palynology. School of Geography and Earth Resources, University of Hull, Miscellaneous Sciences, 35, 1-20.

FORTEY, N. J., MERRIMAN, R. J. \& HUFF, W. D. 1996. Silurian and late Ordovician Kbentonites as a record of late Caledonian volcanism in the British Isles. Transactions of the Royal Society of Edinburgh: Earth Sciences, 86, 167-180.

FROGNER, P., GISLASON, S. R. \& ÓSKARSSON, N. 2001. Fertilizing potential of volcanic ash in ocean surface water. Geology 29, (6) 487-490.

Frost, B. W. 1996. Phytoplankton bloom on iron rations. Nature, 383, 475-476.

FUNKHOUSER, J. W. \& EVITT, W. R. 1959. Preparation techniques for acid-insoluable microfossils. Micropaleontology, 5, (3), 369-375.

GELSTHORPE, D. N. 2002. Testing of palynological processing techniques: an example using Silurian palynomorphs from Gotland, Journal of Micropalaeontology, 21, 81-86.

Grafin, Y. \& CAPUTO, M. V. 1992. Early Silurian glaciations in Brazil. Palaeogeography, Palaeoclimatology, Palaeoecology, 99, 9-15.

GRAY, J. 1965. Palynological Techniques. In KUMMEL, B. \& RAUP, D. (eds), Handbook of Paleontological Techniques, 471-587.

HAMBreY, M. J. 1985. The late Ordovician-early Silurian glacial period. Palaeogeography, Palaeoclimatology, Palaeoecology, 51, 273-289.

HAY, W. W. 1988. Palaeoceanography: A review for the GSA Centennial. Geological Society of America Bulletin, 100, 1934-1956.

HAYEK, L. C. and BURA, E. 2001. On the ends of taxon range problem. In JACKSON, J. B. C., LIDGARD, S. and MCKINNEY, F. K. (eds), Evolutionary patterns. Growth, form, and tempo in the fossil record. University of Chicago Press, Chicago and London, 221-244.

HeAth, R. J., Brenchley, P. J. \& MARShall, J. D. 1998. Early Silurian carbon and oxygen stable-isotope stratigraphy of Estonia: implications for climate change. In LANDING, E. \& JOHNSON, M. (eds), Silurian cycles: linkages of dynamic stratigraphy with atmospheric, oceanic and tectonic changes. New York State Museum Bulletin, 491, 313-323. 


\section{REFERENCES}

Hedr, J. E. 1960. The Silurian of Gotland. In REGNELL, G. \& HEDE, J. E. (eds), The Lower Palacopoic of Scania the Silurian of Gotland, International Geological Congress, 21 session, Norden 1960, Guide to excursions, A 22 and C 17, 44-87.

HIIL, P. J. 1974. Stratigraphic palynology of acritarchs from the type area of the Llandovery and the Welsh Borderland. Review of Palaeobotany and Palynology, 18, 11-23.

— DORNING, K. J. 1984. The Llandovery series in the type area. Appendix 1. Acritarchs. In Cocks, L. R. M., WoOdCOCK, N. H., RICKARDS, R. B., TEMPLE, J. T. \& LANE, P. D. (eds), The Llandovery Series in the type area. Bulletin of the British Museum of Natural History, (Geology), 38, (3), 174-176.

IDso, S. B. 1992. The DMS-cloud albedo feedback effect: greatly underestimated? Climatic Change, 21, $429-433$.

JAANUSSON, V., LAUFELD S. \& SKOGLUND, R. 1979. Lower Wenlock faunal and floral dynamics-Vattenfallet section, Gotland. Uppsala, Sveriges Geologiska Undersökning, Series C NR 762, 294 pp.

JEPPSSON, L. 1987. Lithological and conodont distributional evidence for episodes of anomalous oceanic conditions during the Silurian. In ALDRIDGE, R. J. (ed.), Palaeobiology of conodonts. 129-145. Ellis Horwood Limited, Chichester.

1990. An oceanic model for lithological and faunal changes tested on the Silurian record. Joumal of the Geological Society, London, 147, 663-674.

1993. Silurian Events: the theory and the conodonts. Proceedings of the Estonian Academy of Sciences, 42, 23-27.

1997. The Anatomy of the Mid-Early Silurian Ireviken Event and a Scenario for P-S Events. In BRETT, C. E. \& BAIRD, G. C. (eds), Paleontological Events Stratigraphic, Ecological, and Evolutionary Implications. Columbia University Press, 451-492.

1998. Silurian oceanic events: summary of general characteristics. In LANDING, E. \& Jomnson, M. (eds). Silurian cycles: linkages of dynamic stratigraphy with atmospheric, oceanic and tectonic changes. New York State Museum Bulletin, 491, 239-257.

\& ALDRIDGE, R. J. 2000. Ludlow (late Silurian) oceanic episodes and events. Journal of the Geological Society, London, 157, 1137-1148. 2001. Discussion on Ludlow (late Silurian) oceanic episodes and events. Journal of the Geological Society, London, 158, 731-732.

\& DORNING, K. J. 1995. Wenlock (Silurian) oceanic episodes and events. Journal of the Geological Society, London 152, 487-498.

\& MANNIK, P. 1993. High-resolution correlations between Gotland and Estonia near the base of the Wenlock. Terra Nova, 5, 348-358. 
JofrsoN, M. E. 1996. Stable cratonic sequences and a standard for Silurian eustasy. Geological Society of America Special Paper, 306, 203-211.

- KAus, D. \& Rong, J. -Y. 1991. Silurian Eustasy. Special Papers in Palaeontology, 44, 145-163.

—ROve; JiA-YU \& KrRSHAW, S. 1998. Calibrating Silurian eustasy against the erosion and burial of coastal paleotopography. In LANDING, E. \& JOHNSON, M. (eds). Silurian cycles: linhages of dynamic stratigraphy with atmospheric, oceanic and tectonic changes. New York State Museum Bulletin, 491, 3-13.

Jones, J. A., Carr, P. F., Fergusson, C. L. \& MCDougall, I. 1995. Silurian volcanism in the Wollondilly Basin, eastern Lachlan Fold Belt, New South Wales. Australian Journal of Earth Sciences, 42, 25-34.

KALJO, D., KIIPLI, T. \& MARTMA, T. 1998. Correlation of carbon isotope events and environmental cyclicity in the east Baltic Silurian. In LANDING, E. \& JOHNSON, M. (eds). Silurian cycles linkages of dynamic stratigraphy with atmospheric, oceanic and tectonic changes. New York State Museum Bulletin, 491, 297-312.

KERR, R. A. 2000. Did Volcanoes Drive Ancient Extinctions? Science, 289, 1130-1131.

KING, C. A. M. 1975 Introduction to physical and biological oceanography. 372 pp., Edward Amold, London.

KIRYANOV, V. V. 1978. Akritarkhi silura Volyno-Podolii. Akademiya Nauk Ukrainskoi SSR, Institut Geologicheskikh Nauk, Keiv, Naukova Dumka, 116 pp., pls 1-20. [In Russian].

LAUFELD, S. 1974. Silurian Chitinozoa from Gotland. Fossils and Strata, 5, 1-130.

— \& BASSETT, M. G., 1981. Gotland: the anatomy of a Silurian carbonate platform. Episodes, 2, 23-27.

\& JEPPSSON, L. 1976. Silicification and bentonites in the Silurian of Gotland. Geologiska Föreningens i Stockolm Förhandlingar, 98, 31-44.

LegGetT, J. K., MCKkrRow, W. S., COCKS, L. R. M. \& RICKARDS, R. B., 1981. Periodicity in the early Palaeozoic marine realm. Journal of the Geological Society, London, 138, 167-176.

LE Hérissé, A. 1989. Acritarches et kystes d'algues Prasinophycées du Silurien de Gotland, Suède. Palaeontographia Italica. 76, 57-302, pls 1-30.

— \& GOURVENNEC, R. 1995. Biogeography of upper Llandovery and Wenlock acritarchs. Review of Palaeobotany and Palynology, 86, 111-133.

LISITZIN, A. P. 1996. Oceanic sedimentation Lithology and Geochemistry. KENNETT, J. P. (ed. of English translation). American Geophysical Union, Washington, 400pp. 
LISTER, T. R. 1970. A monograph of the acritarchs and Chitinozoa from the Wenlock and Ludlow series of the Ludlow and Millichope areas, Shropshire. Palaeontological Society [Monograph], 124, (1), 1-100, pls 1-13.

LITWN, R. J. \& TRAVERSE, A. 1989. Basic Guidelines for palynomorph extraction and preparation from sedimentary rocks. In FELDMAN, R. M., CHAPMAN, R. E. \& HANNBAL, J. T. (eds.) Palaeo-techniques; Paleontological Society Special Publication. 4, 87-98.

LOEBLCH, A. R. Jr. 1970. Morphology, ultrastructure and distribution of Paleozoic acritarchs. Proceadings of the North American Paleontological Convention, Chicago, 1969, part G, 2, 705-788, pls 1-38.

LOYDELL, D. K. 1992. Upper Aeronian and Lower Telychian (Llandovery) graptolites from westem mid-Wales. Part 1. Palaeontographical Society Monograph, 146 (589), 1-55, pl. 1.

1994. Barly Telychian changes in graptoloid diversity and sea level. Geological Journal, 29, 355-368.

1998. Early Silurian sea-level changes. Geological Magazine, 135, 447-471.

- KALJO, D. \& MANNIK, P. 1998. Integrated biostratigraphy of the lower Silurian of the Ohesaare core, Saaremaa, Estonia. Geological Magazine 135, (6), 769-783.

MABILLARD, J. E. \& ALDRIDGE, R. J. 1985. Microfossil distribution across the base of the Wenlock Series in the type area. Palaeontology, 28, 89-100.

MACLEOD, N. \& KELLER, G. 1991. How complete are Cretaceous/Tertiary boundary sections? A chronostratigraphic estimate based on graphic correlation. Geological Society of America Bulletin, 103, 1439-1457.

MaNTEN, A. A. 1971. Silurian Reefs of Gotland. Developments in Sedimentology, 13, (i-x), Elsevier, 539 pp.

Marshaul, C. R. 1998. Determining Stratigraphic Ranges. In DonovaN, S. K. \& PaUl, C. R. C. (eds), The Adequacy of the Fossil Record. 23-54.

MARTIN, F. 1966. Les Acritarches du sondage de la brasserie Lust, à Kortrijk (Courtrai) (Silurien belge). Bulletin de la Société belge de geologie, de paléontologie, et d'hydrologie, 74, (2), 354-400, 1 pl.

1967. Les Acritarches du parc de Neuville-sous-Huy (Silurien belge). Bulletin de la Societé belge de geologie, de paléontologie, et d'hydrologie, 75, (3), 306-335, pl. 1. 1969. Les acritarches de l'Orovicien et du Silurien Belges. Détermination et valeur stratigraphique. Institut royal des sciences naturelles de Belgique, Mémoire, 160, pp. 175, pls 1-8, [cover date 1968, issue date 1969].

1993. Acritarchs: a review. Biological reviews of the Cambridge Philosophical Society, 68, (4), 475-538, pls 1-3. 
一, J. H., Conlb, K. H., Jomson, K. S., Fitzwater, S. E., Gordon, R. M., TANnER, S. J.,

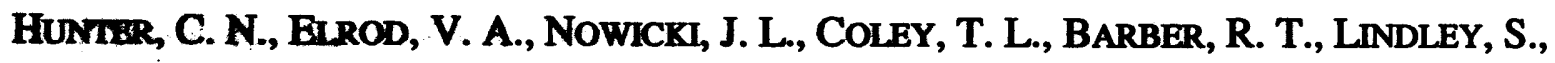
Watson, A. J., VAN ScoY, K., LAw, C. S., Liddicoat, M. I., LING, R., STanton, T., Stockzi, J., Collins, C., ANDERSON, A., Bidigare, R., ONDRUSEK, M., LATASA, M., Minlero, F. J., Lee, K., YaO, W., Zhang, J. Z., Friederich, G., SAKamoto, C., Geavez, F., BuCK, K., Kolber, Z., Greene, R., FAlKowski, P., Chisholm, S.W., Hoge, F., Swim, R., Yungel, J., TuRner, S., Nightingale, P., Hatton, A., Liss, P. \& Tonduz, N. W. 1994. Testing the iron hypothesis in ecosystems of the equatorial Pacific Ocean. Nature, 371, 123-129.

MARTINsson, A. 1962. Ostracodes of the family Beyrichiidae from the Silurian of Gotland.

Bulletin of the Geological institutions of the University of Uppsala, 41, 1-369.

1967. The staccession and correlation of ostracode faunas in the Silurian of Gotland. Geologiska Föreningens $i$ Stockholm Förhandlingar, 89, 350-386.

MATTHEwS, S. C. 1973. Notes on open nomenclature and on synonymy lists. Palaeontology, 16, (4), 713-719.

Moldowan, J. M., Darl, J., Jacobson, S. R., Huizinga, B. J., FAGO, F. J., ShETTY, R., WATT, D. S. \& PETERS, K. E. 1996. Chemostratigraphic reconstruction of biofacies: molecular evidence linking cyst-forming dinoflagellates with pre-Triassic ancestors. Geology, 24, (2), 159-162.

MORGENROTH, P. 1968. Zur Kenntnis der Dinoflagellaten und Hystrichospaeridien des Danien. Geologisches Jahrbuch, Hannover, 86, 533-578, pls. 41-48.

Muluns, G. L. 2001. Acritarchs and prasinophyte algae of the Elton Group, Ludlow Series, of the type area. Palaeontographical Society [Monograph], 155, 1-154, pls 1-18.

MUYLAERT, K, SABBE, K. \& VYVERMAN, W. 2000. Spatial and Temporal Dynamics of Phytoplankton Communities in a Freshwater Tidal Estuary. Estuarine, Coastal and Shelf Science, 50, 673-687.

NEwTon, E. T. 1875. On 'Tasmanite' and Australian 'white coal'. Geological Magazine, 12, (8), 337-342, 1 pl.

NEWTON, P. 1997. Climate's carbonate cypher. Nature, 390, 445.

Paris, F., BourahrouH, A., Le HÉrissé, A. 2000. The effects of the final stages of the Late Ordovician glaciation on marine palynomorphs (chitinozoans, acritarchs, leiospheres) in well NI-2 (NE Algerian Sahara). Review of Palaeobotany \& Palynology, 113, 87-104.

PIROzYNSKa, K. A. 1976. Fungal spores in fossil record. Palaeopalynology, 4, Biol. Mem. 1 (1/2), $104-120$.

PLAYFORD, G. 1977. Lower to Middle Devonian acritarchs of the Moose River Basin, Ontario. Geological Survey of Canada, Bulletin, 279, 1-87, pls 1-20. 
RAllsaACK, L. B. 1990. Influence of changing deep ocean circulation on the Phanerozoic oxygen isotopic record. Geochimicia et Cosmochimica Acta, 54, 1501-1509.

Richardson, J. B. \& RasUL, S. M. 1990. Palynofacies in a Late Silurian regressive sequence in the Welsh Borderland and Wales. Journal of the Geological Society, London, 147, 675686.

RIDNG, R. 1981. Composition, structure and environmental setting of Silurian bioherms and biostromes in northern Europe. Society of Economic Paleontologists and Mineralogists [Special Publication], 30, 41-83.

RIGBY, S. \& DAVIES, S. 2000. Volcanically mediated plankton blooms in the Central Belt of the Southern Uplands, Scotland, during the Llandovery. Transactions of The Royal Society of Edinburgh Earth Sciences, 91, 457-470.

Ross, C. A. \& Ross, J. R. P. 1996. Silurian sea-level fluctuations. Geological Society of America, Special paper, 306, 187-192.

SAMTLEBEn, C., MUNNECKE, A., BiCKERT, T. \& PÄTZOLD, J. 1996. The Silurian of Gotland (Sweden): facies interpretation based on stable isotopes in brachiopod shells. Geologische Rundsch, 85, 278-292.

SARJEANT, W. A. S. \& STANCLIFFE, R. P. W. 1994. The Micrhystridium and Veryhachium complexes (Acritarcha: Acanthomorphitae and Polygonomorphitae): a taxonomic reconsideration. Micropalaeontology, 40, (1), 1-77, 1 pl.

SCHAARSCHMIDT, F. 1963. Sporen und Hystrichosphaerideen aus dem Zechstein von Budingen in der Waterau. Palaeontographica, Abt. B, 113, (1-4), 38-91, pls 11-20.

Schulz, G. 1967. Mikrofossilien des oberen Llandovery von Dalarne (Schweden). Kölner Geologische Hefte, 13, 175-187, 1 pl.

SERVAIS, T., Brocke, R., FATKA, O., LE HÉRISSÉ, A. \& MOlYNEUX, S. G. 1996. Value and meaning of the term acritarch. Geologica, 40, 631-643.

SHAW, A. B. 1964. Time in stratigraphy. International series in the Earth Sciences, 365 pp.

SHI, G. R. 1993. Multivariate data analysis in palaeoecology and palaeobiogeography-a review. Palaeogeography, Palaeoclimatology, Palaeoecology, 105, 199-234.

SIMO, R. \& PEDRÓS-ALIo, C. 1999. Role of vertical mixing in controlling the oceanic production of dimethyl sulphide. Nature, 402, 396-399.

StAPlin, F. L., JANSONIUS, J. \& PoCKOCK, S. A. J. 1965. Evaluation of some acritarchous hystrichosphere genera. Neues Jahrbuch für Geologie und Paläontologie. Abhandlungen, 123, (2), 167-201, pls 18-20.

STEINKE, M., MALIN, G., ARCher, S. D., BURKHILL, P. H. \& LISS, P. 2002. DMS production in a coccolithophorid bloom: evidence for the importance of dinoflagellate DMSP lyases. Aquatic Microbial Ecology, 26, 259-270. 
Stocknans, F. W. \& WHürese, Y. 1962a. Hystrichosphères du Dévonien belge (Sondage de l'Asile d'aliénés à Toumai). Bulletin de la Société belge de géologie, de paléontologie et d'hydrologie, 71, (1), 41-77, pls 1-2.

1962b. Description de trios Hystrichosphères trouvé dans les schistes de l'horizon marin de petit buisson, In LECKWIJ, W. P. \& CHESAUX, C. H. (eds). Étude de l'Horizon Marin de Petit Buisson dans la Partie Occidentale du Massif du Borinage. In Observations sur la Paléontologie, la Lithologie et la Stratigraphie du Westphalien B et C dans la Partie Occidentale Occidentale du Massif du Borinage (District du Couchant de Mons). Centre national de géologie houllère (Belgium), 5, 11-30.

Strong, A. E. 1993. A Note on the Possible Connection Between the El Chichón Eruption and Ocean Production in the Northwest Arabian Sea During 1982. Journal of Geophysical Research, 98, (C1), 985-987.

TAPPAN, H. 1980. Palaeobiology of plant protists, 1028 pp., Freeman, San Francisco.

1986. Phytoplankton: below the salt at the global table. Journal of Paleontology, 60, 545-554.

ThusU, B. 1973. Acritarches provenant de l'Ilion shale (Wenlockien), Utica, New York. Micropaléontologie, 16, (2), 137-146, pls 1-2.

TONGIORGI, M. \& Di MinIA, A. 1999. Differentiation and spread of the Baltic Acritarch Province (Arenig-Llanvirn). Bollettino della Società Paleontologica Italiana, 38, (2-3), 297-312.

TORSVIK, T. H., Olesen, O., RYAN, P. D. \& TRENCH, A. 1990. On the palaeogeography of Baltica during the Palaeozoic: new palaeomagnetic data from the Scandinavian Caledonides. Geophysical Journal International, 103, 261-279.

Traverse, A., 1988. Paleopalynology. Allen and Unwin, Boston. 600pp.

TURNER, R. E. 1984. Acritarchs from the type area of the Ordovician Caradoc Series, Shropshire, England. Palaeontographica Abt. B, 190, (4-6), 87-157, pls 1-14.

TuRner, S. M., Nightingale, P. D., SPOKES, L. J., LidDicoAT, M. I. \& LisS, P. S. 1996. Increased dimethyl sulphide concentrations in sea water from in situ iron enrichment. Nature, 383, 513-517.

VeRSTEEGH, G. J. M. \& ZoNNEVELD, K. A. F. 1994. Determination of (palaeo-) ecological preferences of dinoflagellates by applying Detrend and Canonical Correspondence analysis to Late Pliocene dinoflagellate cyst assemblages of the south Italian Singa section. Review of Palaeobotany and Palynology, 84, 181-199.

WATKINS, J. L., MORRIS, D. J., RicketTS, C. \& MURRAY, A. W. A. 1990. Sampling biological characteristics of Krill: effect of heterogeneous nature of swarms. Marine Biology, 107, 409-415. 
WATSON, A. J. 1997. Volcanic iron, $\mathrm{CO}_{2}$, ocean productivity and climate. Nature, 385, 587588.

WATTS, N. R. \& RIDING, R. 2000. Growth of rigid high-relief patch reefs, Mid-Silurian, Gotland, Sweden. Sedimentology, 47, 979-994.

WEISSERT, H. 2000. Deciphering methane's fingerprint. Nature, 406, 356-357.

WENZzR, B. \& JOACHIMSKI, M. M. 1996. Carbon and oxygen isotopic composition of Silurian brachiopods (Gotland/Sweden): palaeoceanographic implications. Palaeogeography, Palaeoclimatology, Palaeoecology, 122, 143-166.

LECUYER, C. \& JOACHIMSKI, M. M. 2000. Comparing oxygen isotope records of Silurian calcite and Phosphate- ${ }^{18} \mathrm{O}$ compositions of brachiopods and conodonts. Geochimica et Cosmochimica Acta, 64, (11), 1859-1872.

WETZEL, W. 1952. Beitrag zur Kenntnis des den-zeitlichen Meeres-planktons. Geologisches Jahrbuch, Hannover, 66, 391-419, 1 pl.

WICANDER, E. R. 1974. Upper Devonian-Lower Mississippian acritarchs and prasinophycean algae from Ohio, U.S.A. Palaeontographica, Abt. B, 148, (1-3), 9-43, pls 5-19.

Williams, G. L., SarJeant, W. A. S., KIDSON, E. J. 1978. A Glossary of the Terminology Applied to Dinoflagellate Amphiesmae and Cysts and Acritarchs: 1978 Edition. American Association of Stratigraphic Palynologists, 2A, 1-121, pls 1-15.

WoOD, G. D., GABRIEL, A. M. \& LAWSON, J. C. 1996. Palynological techniques-processing and microscopy. In JANSONIUS, J. \& MCGREGOR, D. C. (eds), Palynology: principles and applications. American Association of Stratigraphical Palynologists Foundation. (1) 3950. 


\section{Appendix 1}

STRATIGRAPHIC RANGE DIAGRAM FOR ALL THE

BFECIES RECORDED AT LUSKLINT 1 


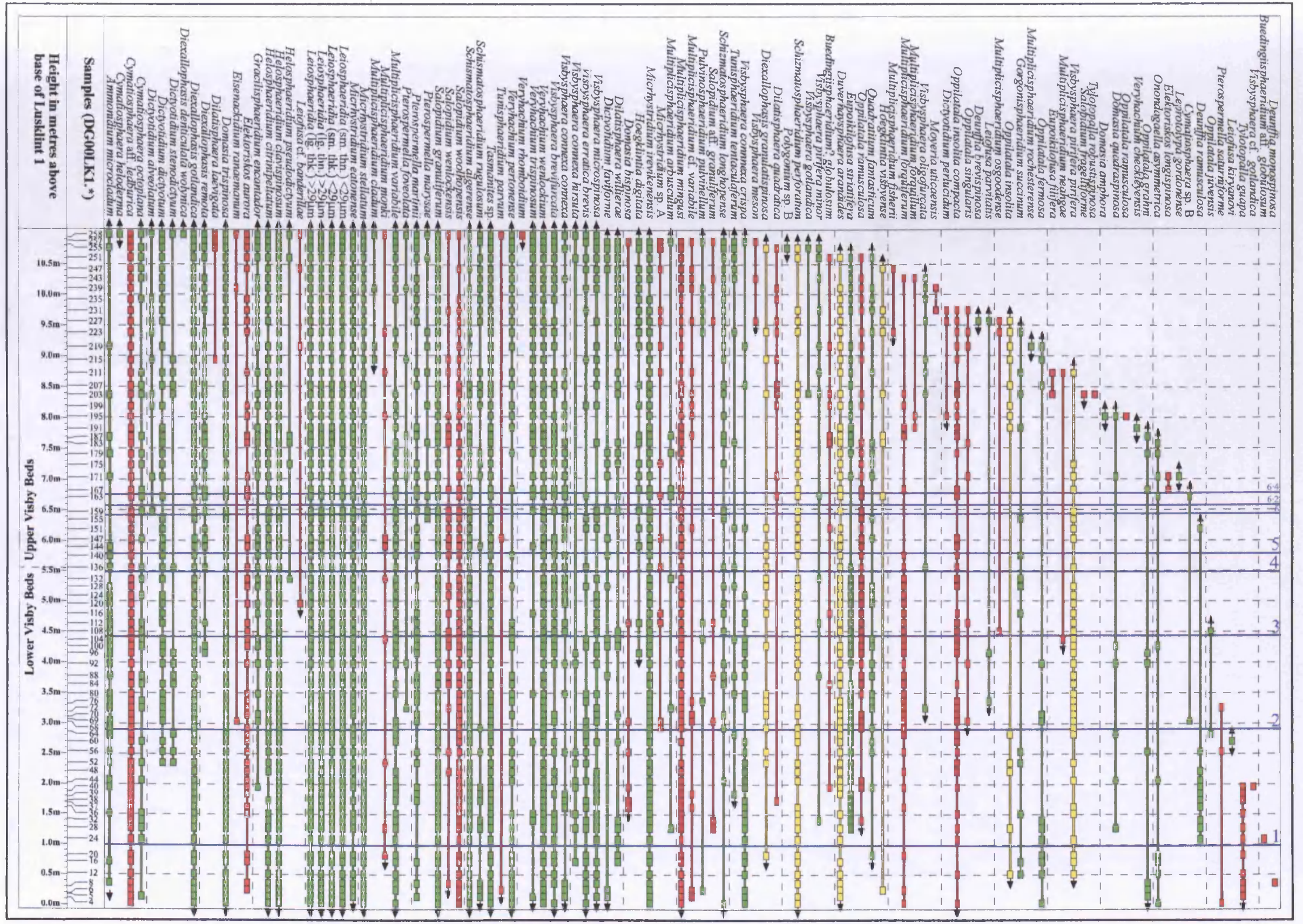

Appendix 1. Stratigraphic range diagram for all the species recorded at Lusklint 1. 


\section{Appendix 2}

STRATIGRAPHIC RANGE DIAGRAM FOR ALL THE SPECIES RECORDED AT LICKERSHAMN 2 


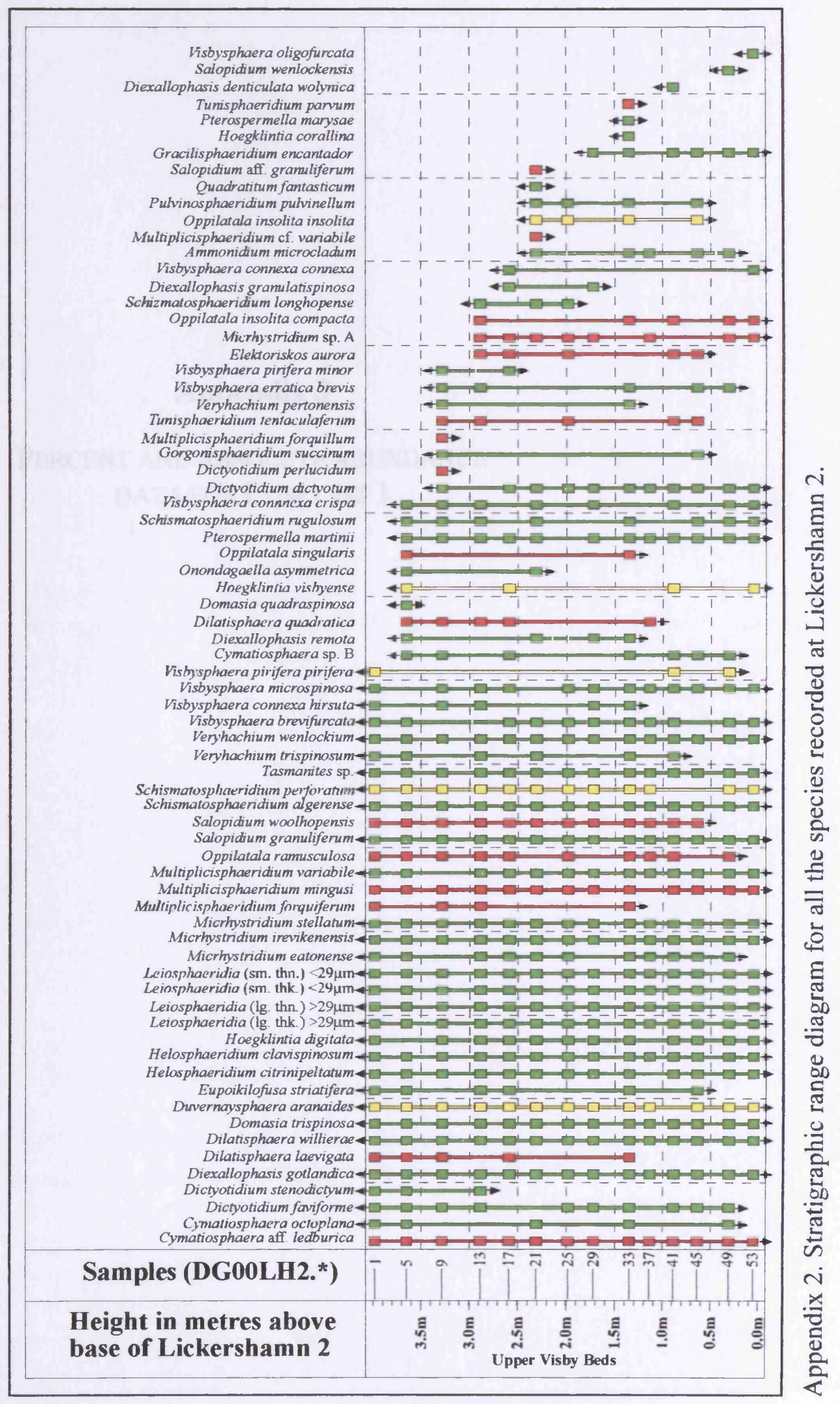


Appendix 3

PERCENT AND ABSOLUTE ABUNDANCE DATA FOR LUSKLINT 1 


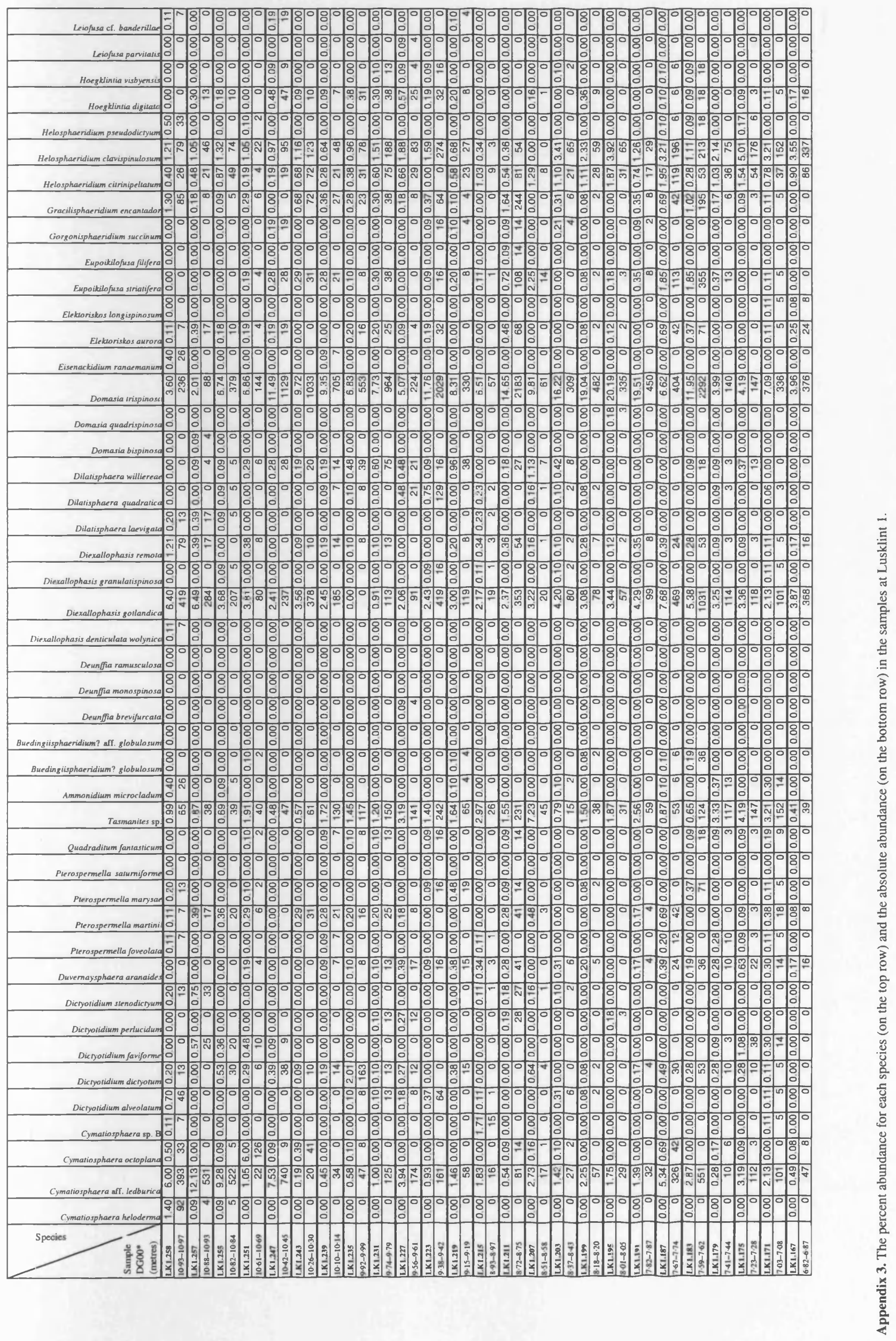




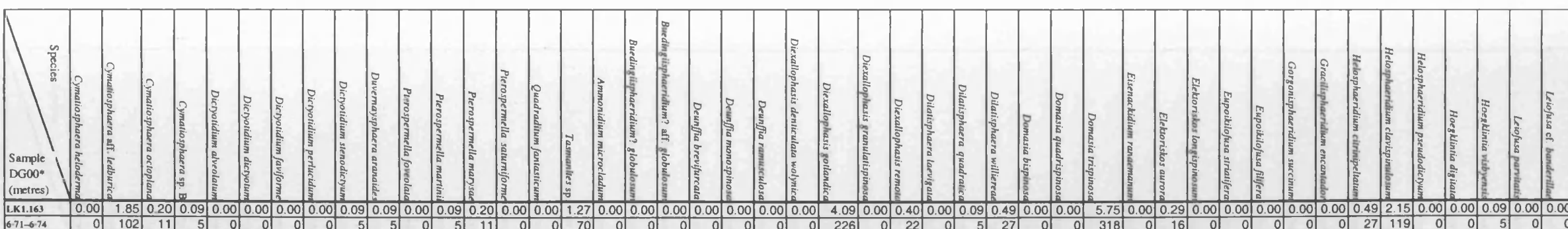

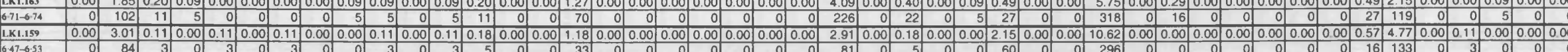

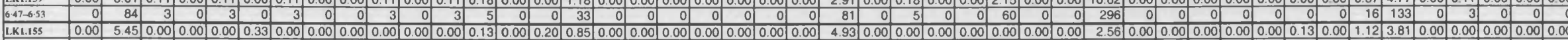

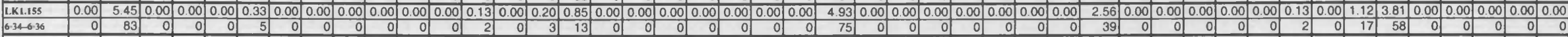

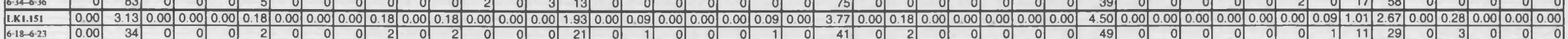

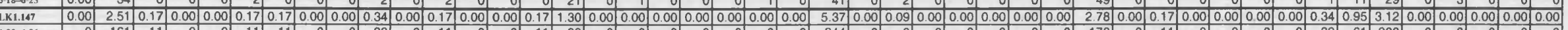

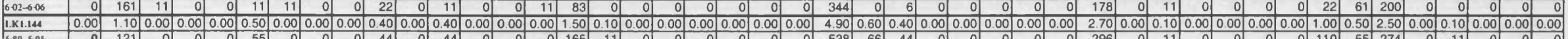

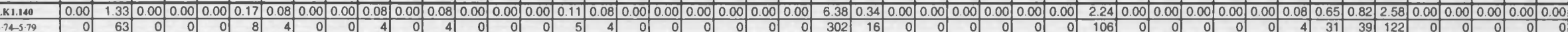

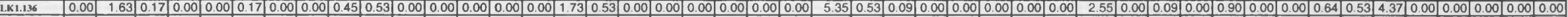

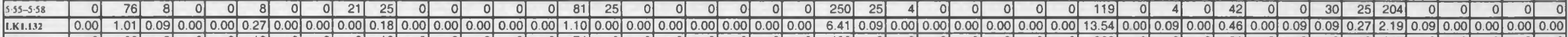

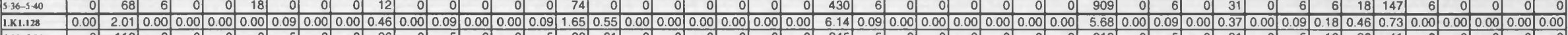

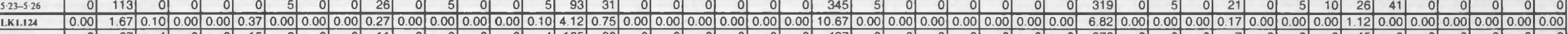

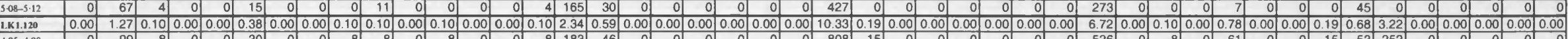

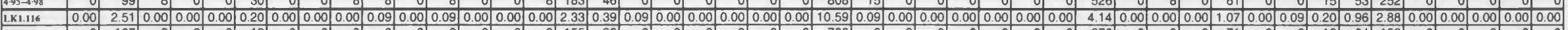

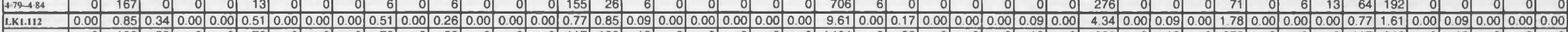

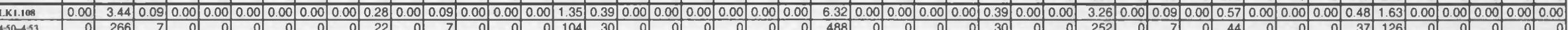

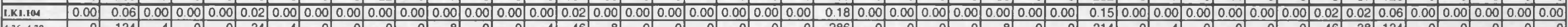

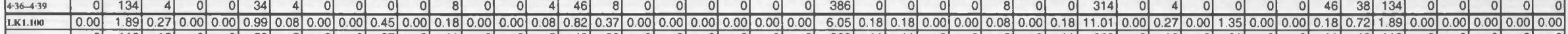
(26-30

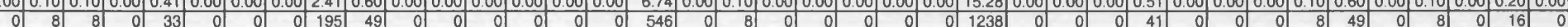

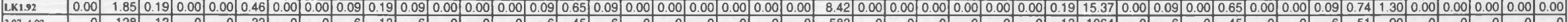

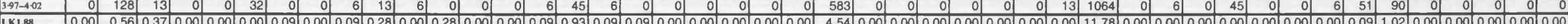

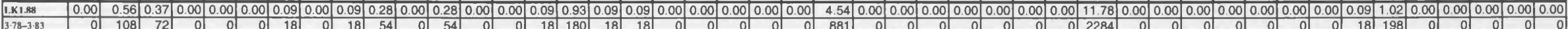

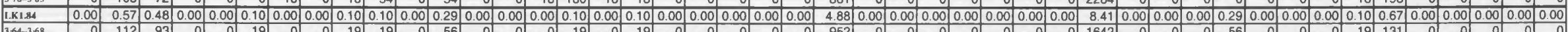

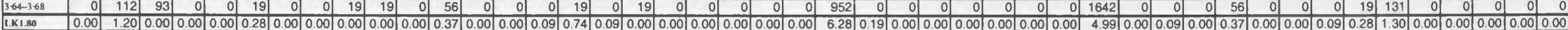

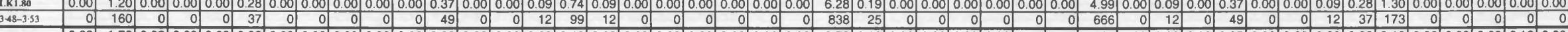

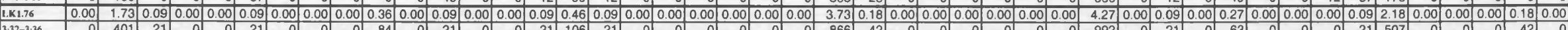

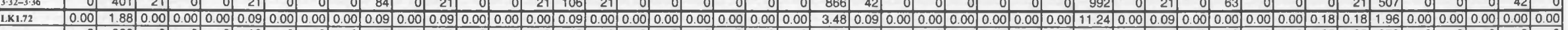

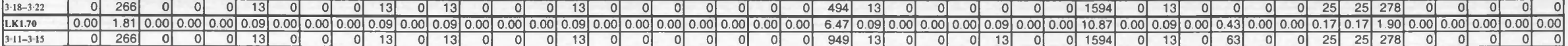




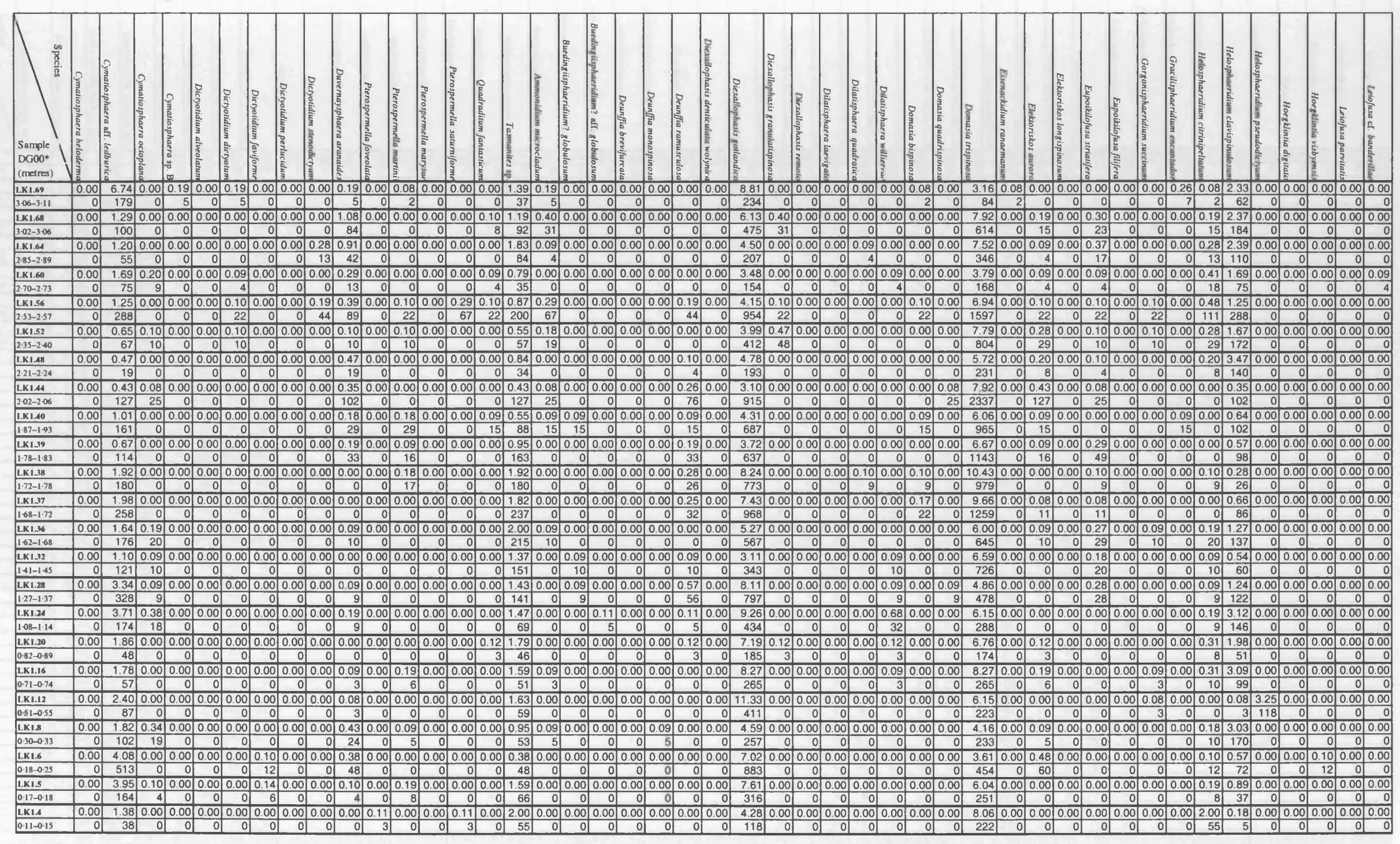

Appendix 3. The percent abundance for each species (on the top row) and the absolute abundance (on the bottom row) in the samples at Lusklint 1. 


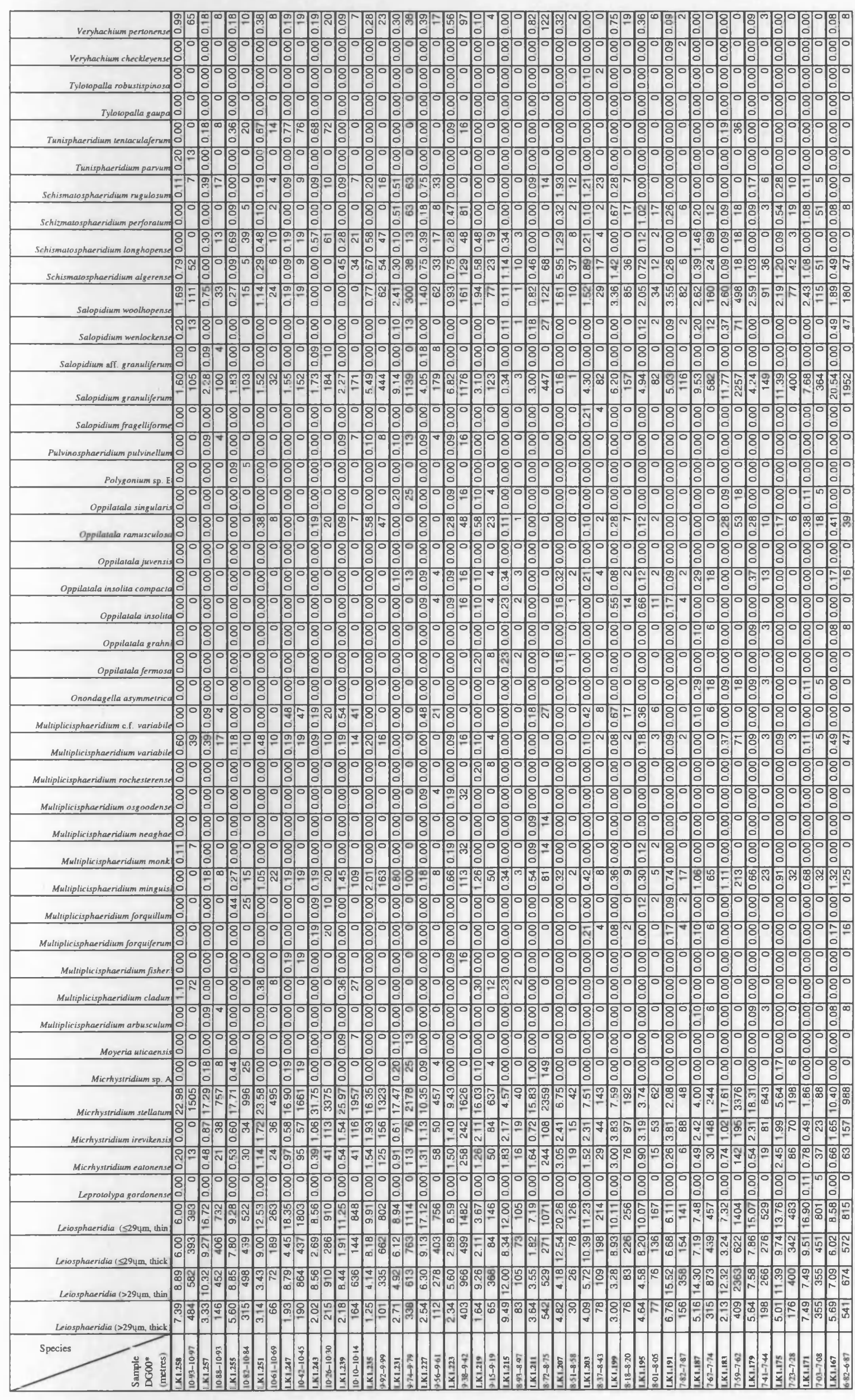




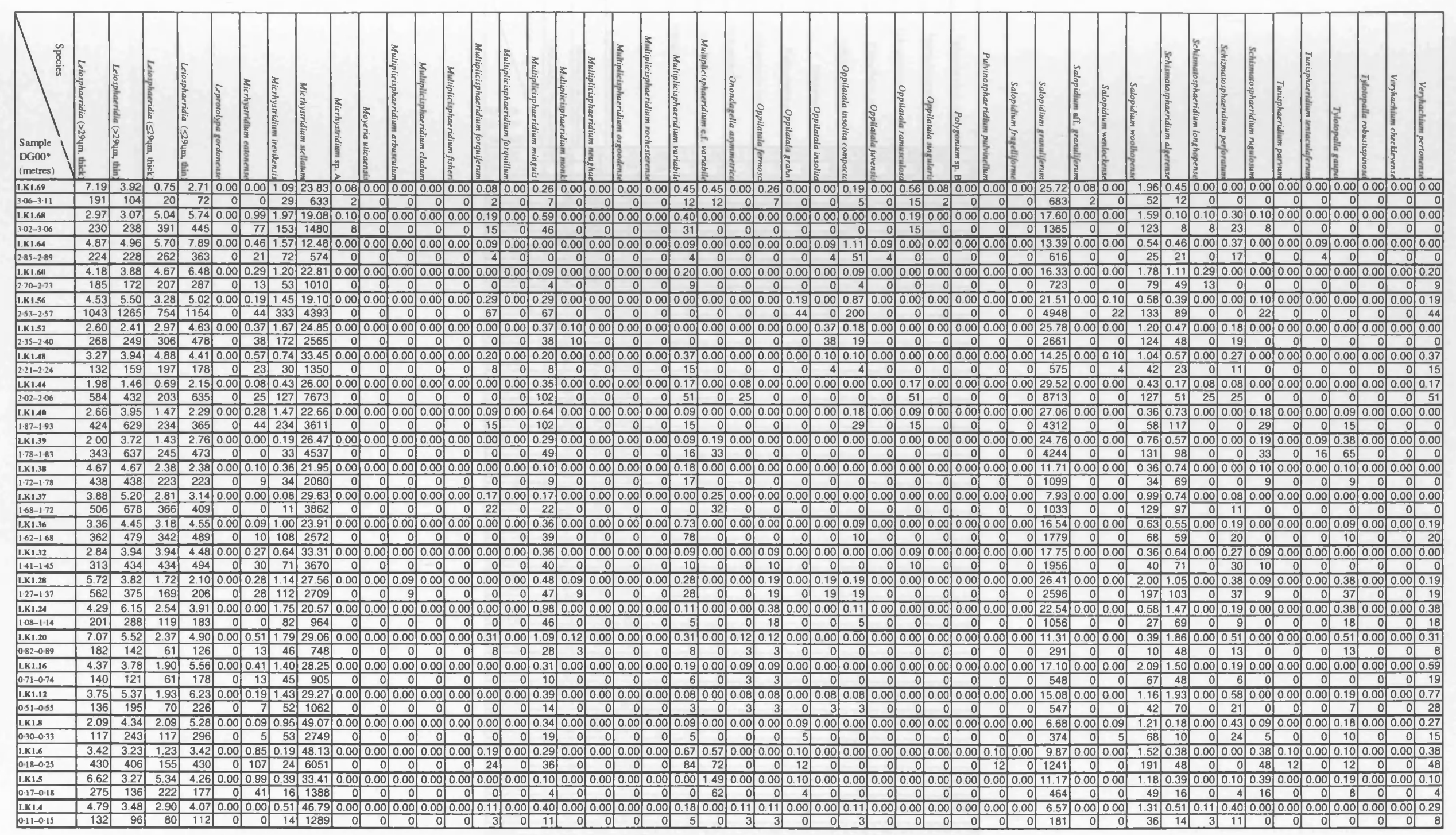

Appendix 3. The percent abundance for each species (on the top row) and the absolute abundance (on the bottom row) in the samples at Lusklint 1 . 


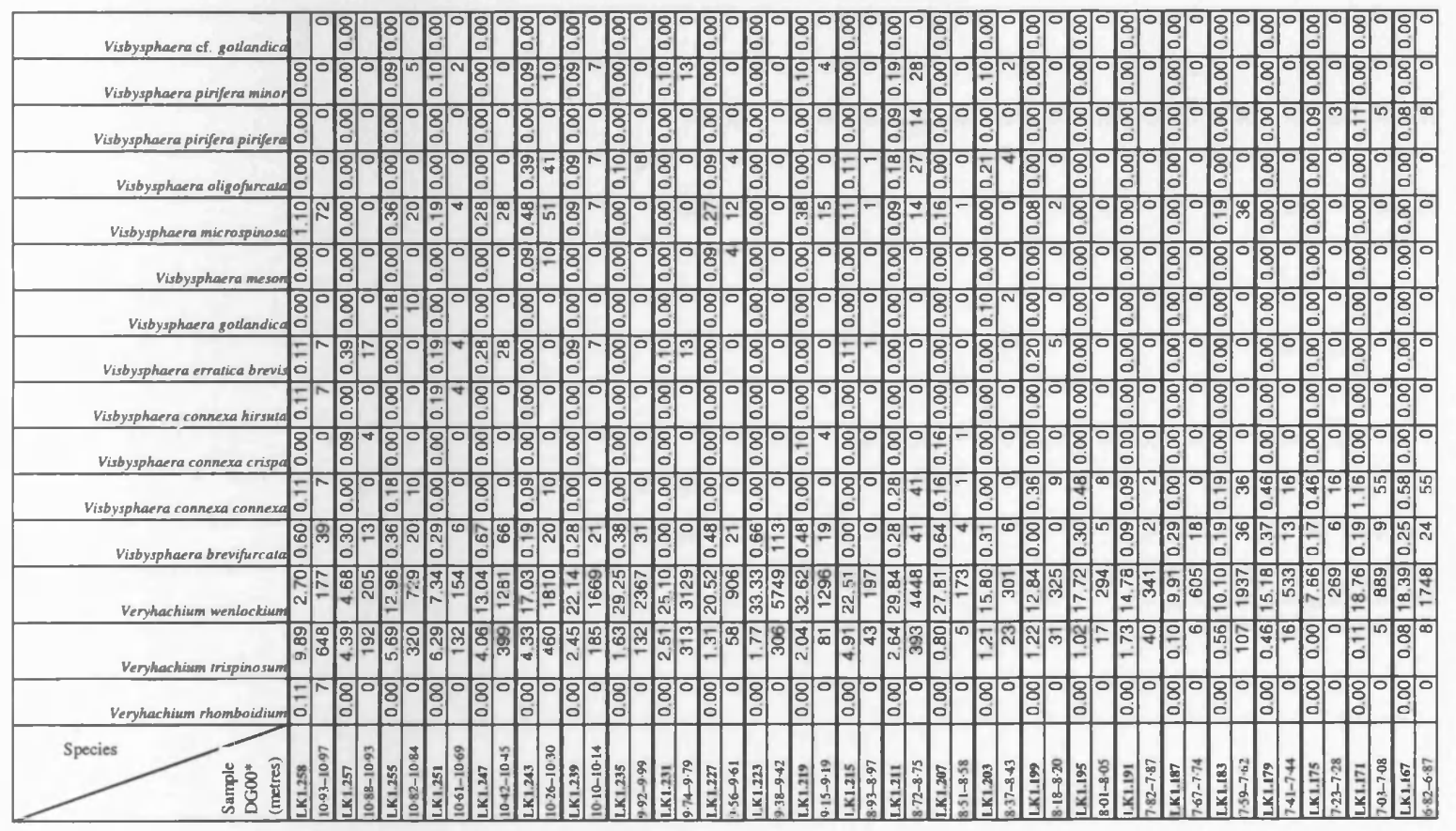




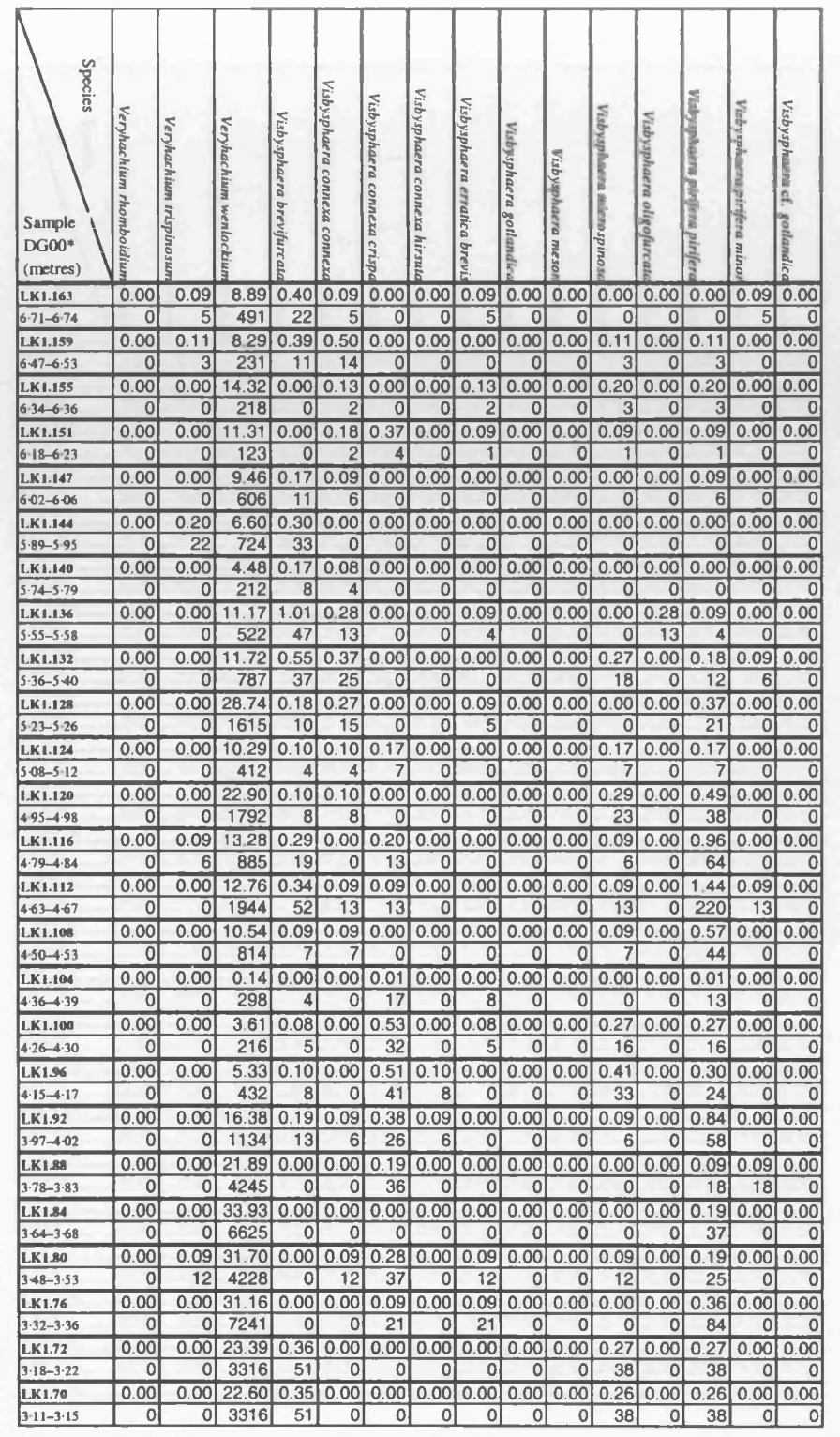

Appendix 3. The percent abundance for each species (on the top row) and the absolute abundance (on the bottom row) in the samples at Lusklint 1 . 


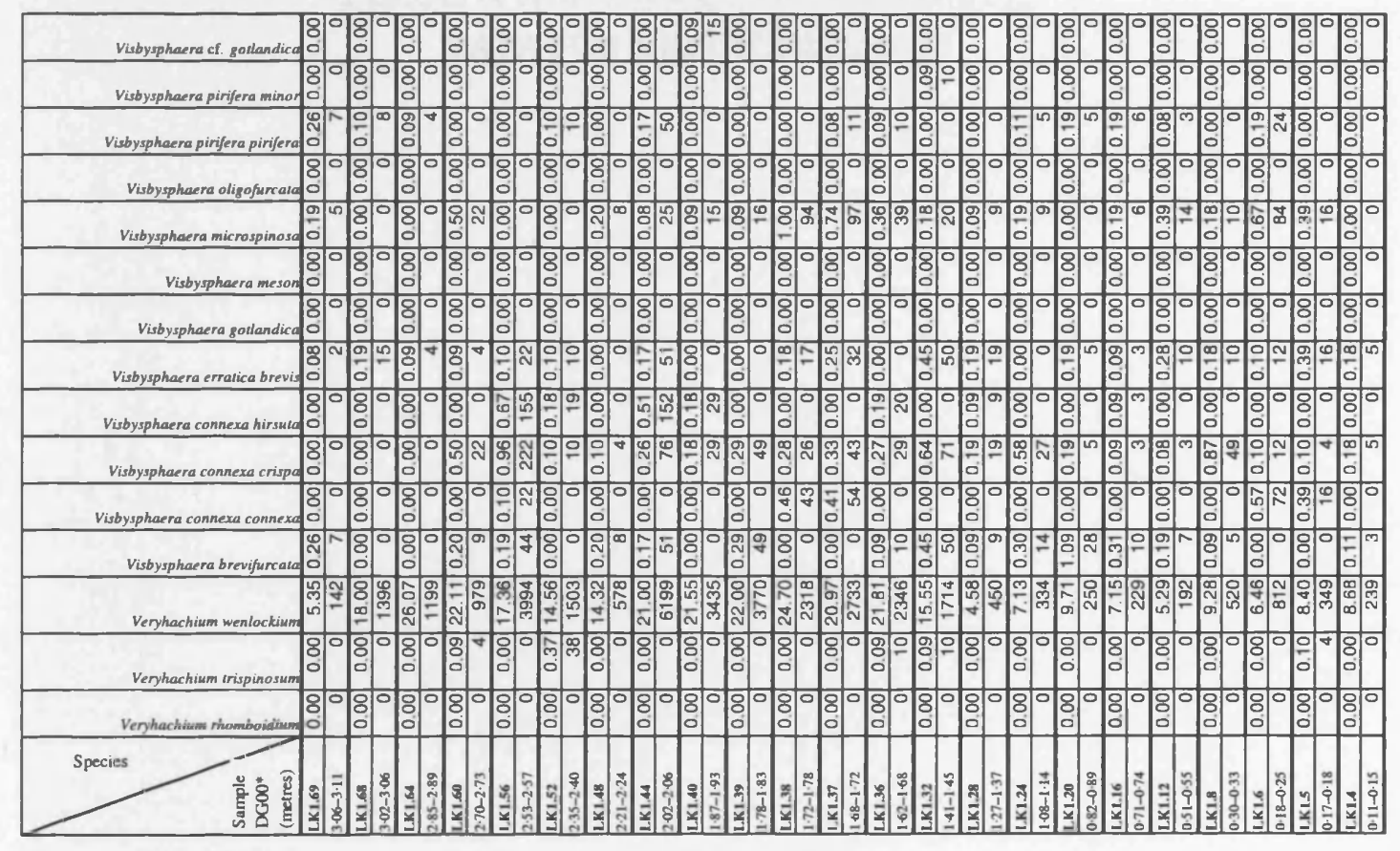




\section{Appendix 4}

PERCENT AND ABSOLUTE ABUNDANCE

DATA FOR LICKERSHAMN 2 


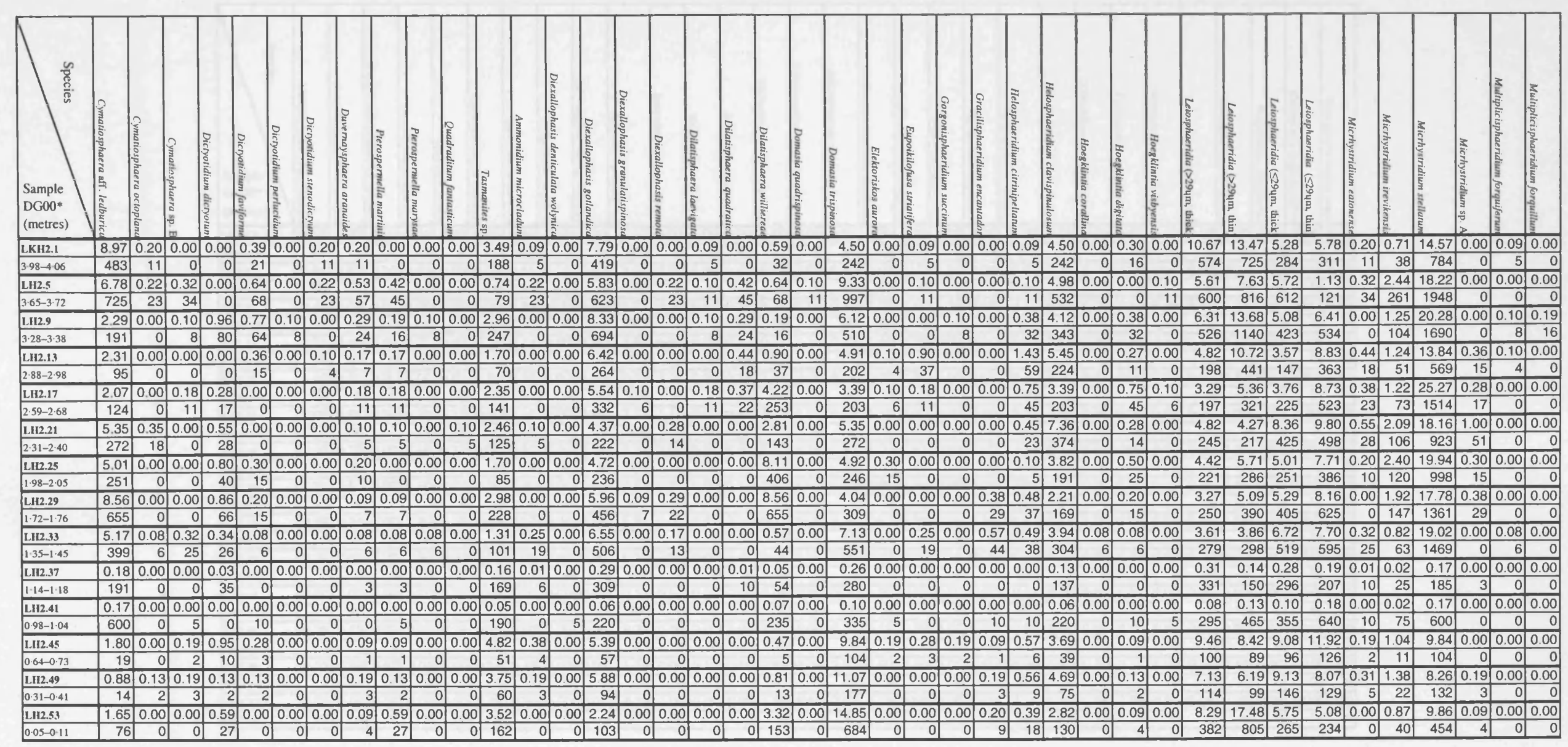

Appendix 4. The percent abundance for each species (on the top line) and the absolute abundance (on the bottom line) in the samples at Lickershamn 2. 


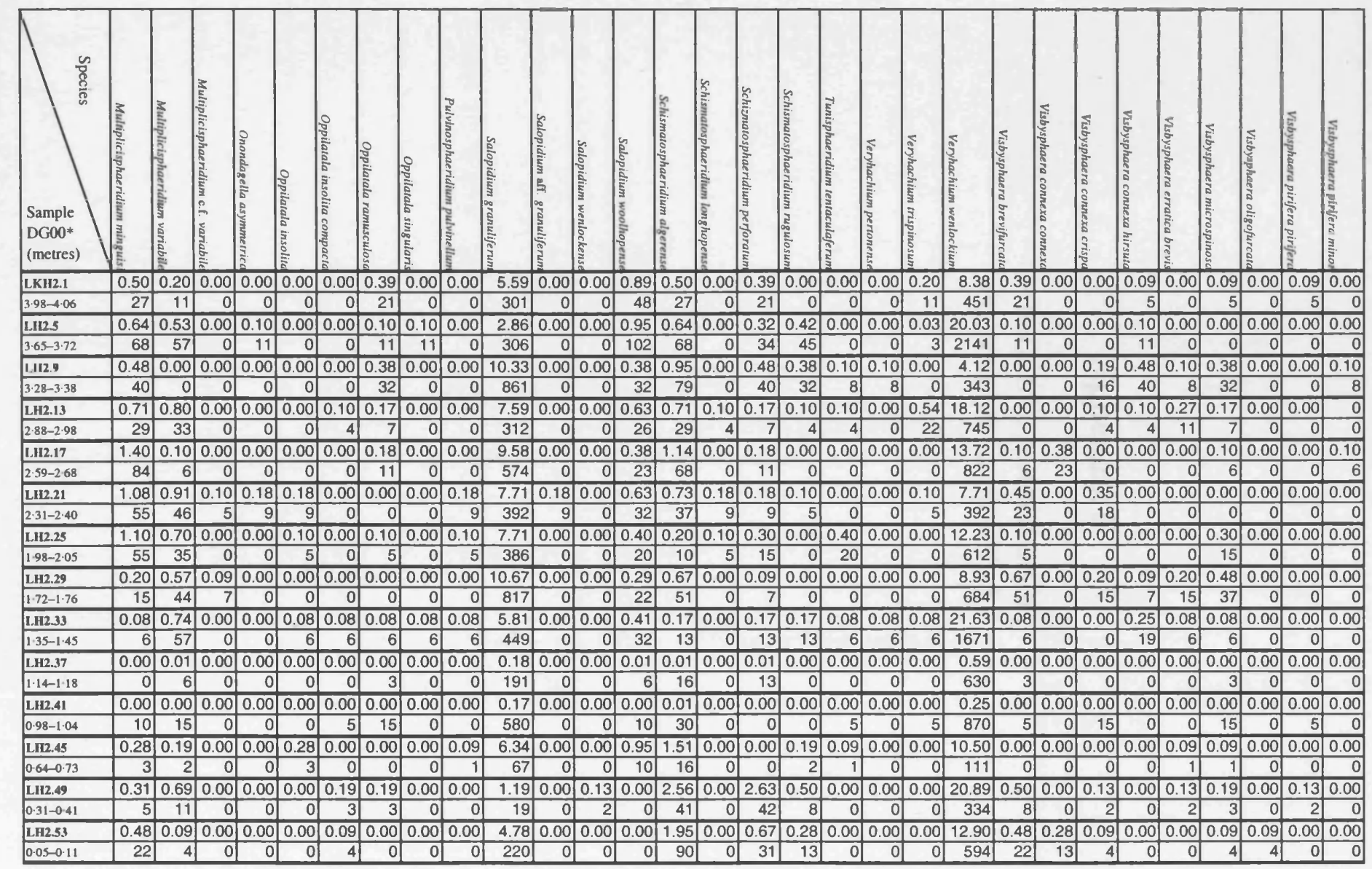

Appendix 4. The percent abundance for each species (on the top line) and the absolute abundance (on the bottom line) in the samples at Lickershamn 2. 
Appendix 5

ABSOLUTE ABUNDANCE

PLOTS FOR LUSKLINT 1 


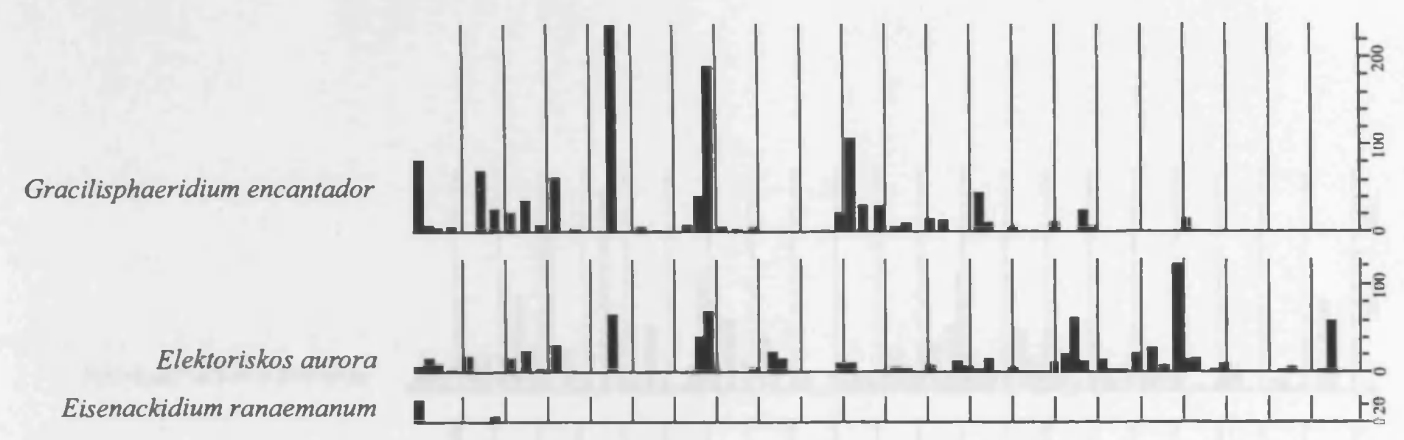

Domasia trispinosa

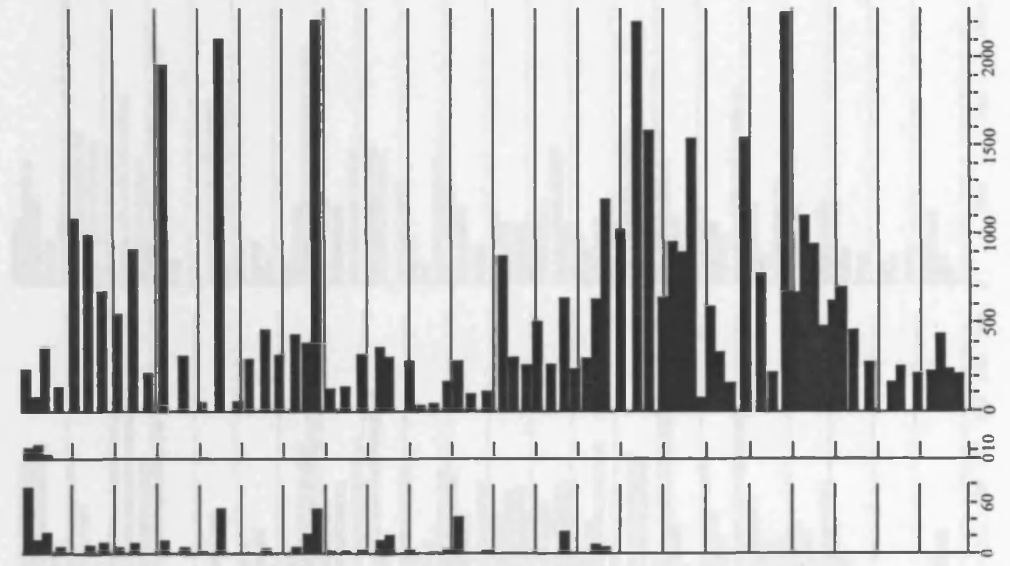

Diexallophasis gotlandica Diexallophasis denticulata wolynica

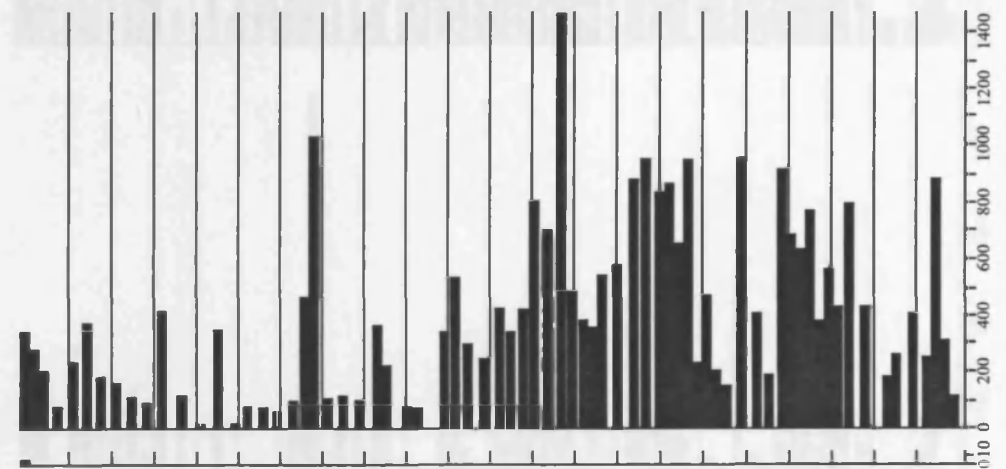

Dictyotidium stenodictyum

Dictyotidium dictyotum

Dictyotidium alveolatum

Cymatiosphaera octoplana
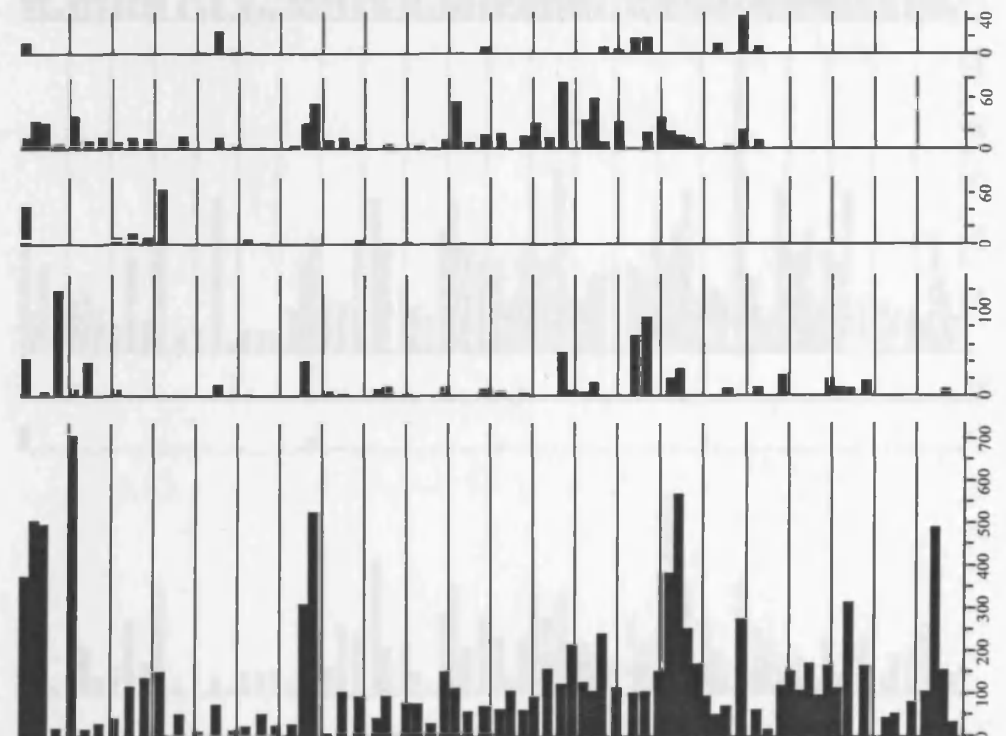

Cymatiosphaera aff. ledburica

Cymatiosphaera heloderma

I

Ammonidium microcladum

Samples (DG00LK1.*)

Height in metres

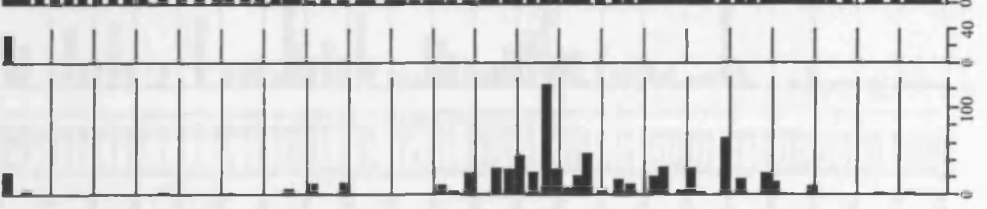

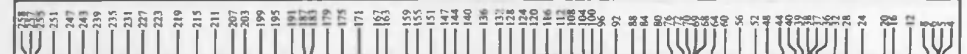

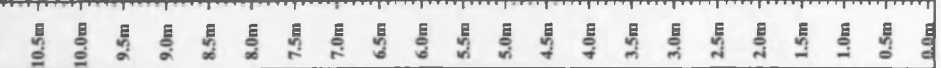

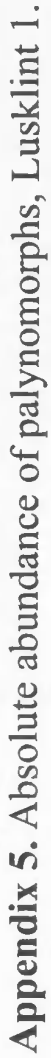




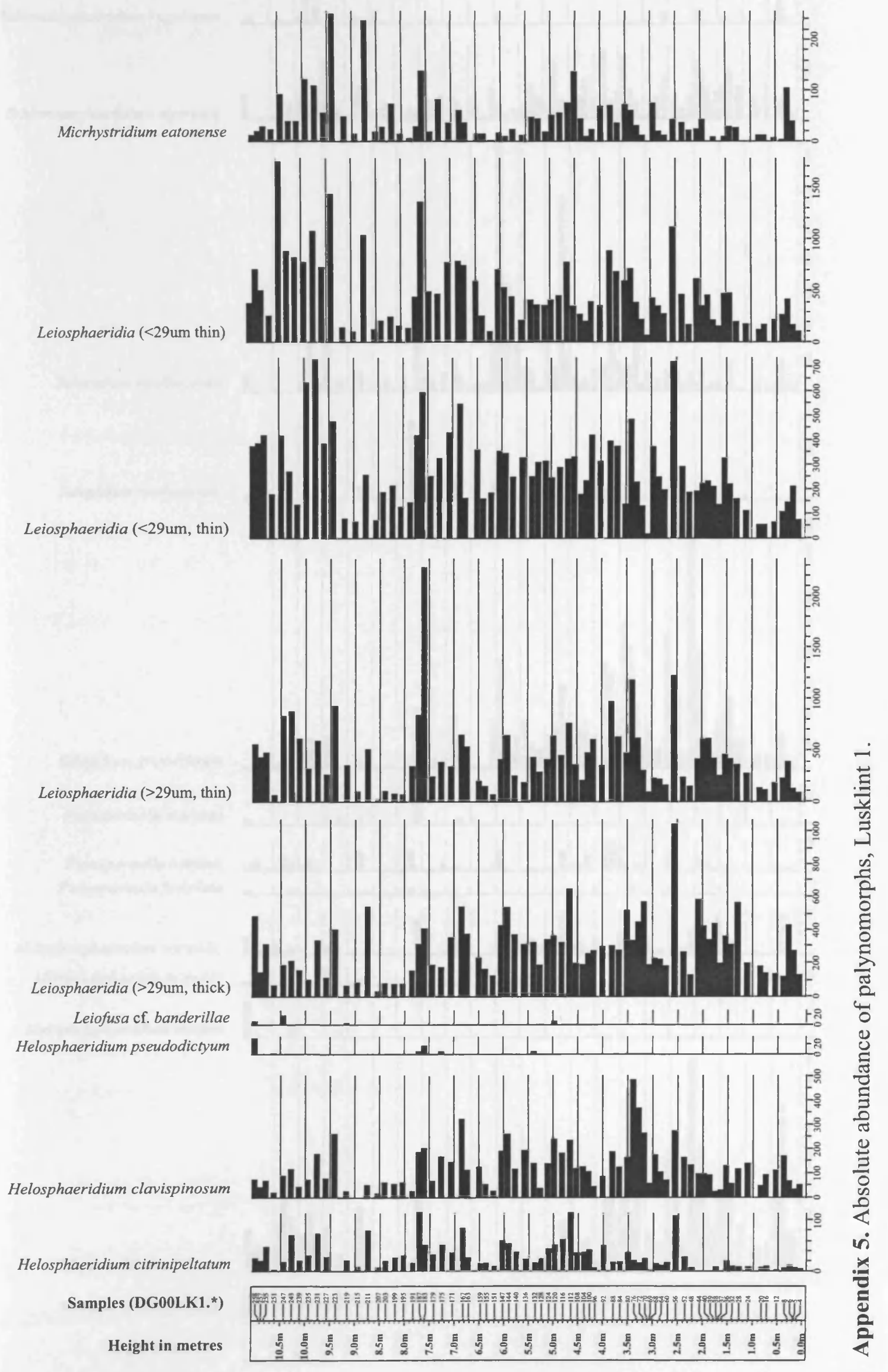




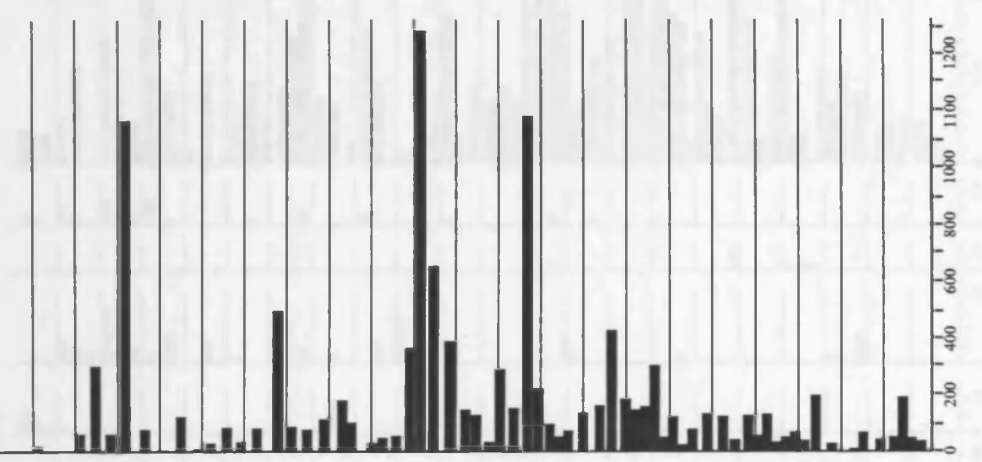

Salopidium woolhopensis

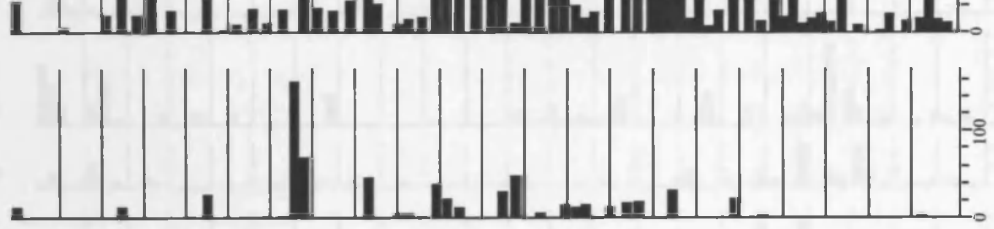

Salopidium wenlockensis

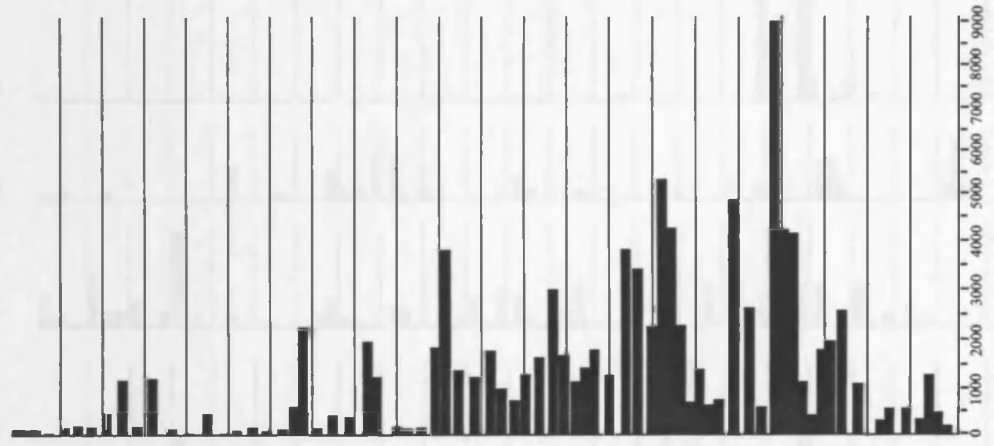

Salopidium granuliferum

Pterospermella marysae

Pterospermella martinii

Pterospermella foveolata
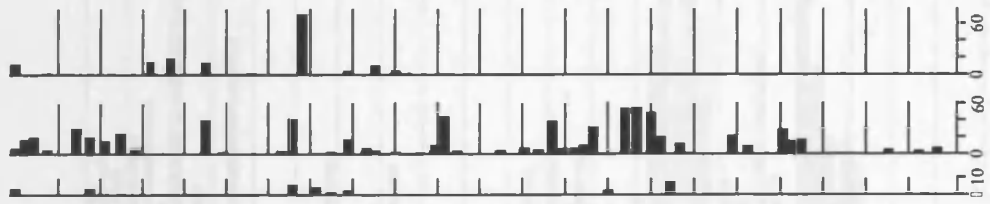

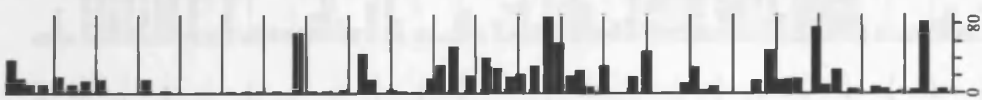

Multiplicisphaeridium variabile

Multiplicisphaeridium monki

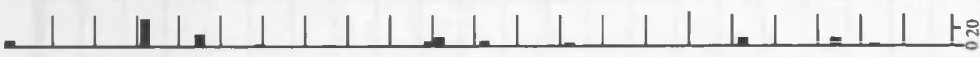

茫

Micrhystridium stellatum

Multiplicisphaeridium cladum

Samples (DG00LK1.*)

Height in metres
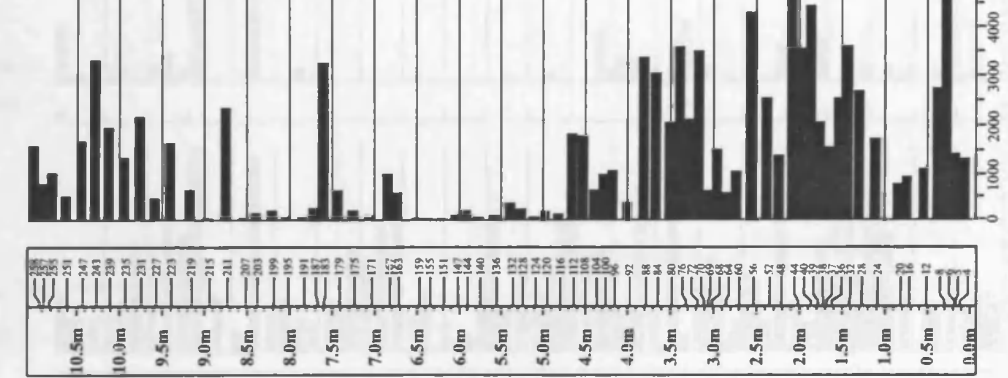
Micrhystridium irevikenensis

Hoegklintia digitata

Domasia bispinosa

Dilatisphaera willierae

Dictyotidium faviforme

Visbysphaera microspinosa Visbysphaera erratica brevis

Visbysphaera connexa hirsuta

Visbysphaera connexa connexa

Visbysphaera brevifuncata

Verhyachium wenlockium

Veryhachium trispinosum Veryhachium rhomboidium

Veryhachium pertonensis Tunisphaeridium parvum

Tasmanites sp.

Samples (DG00LK1.*)

Height in metres
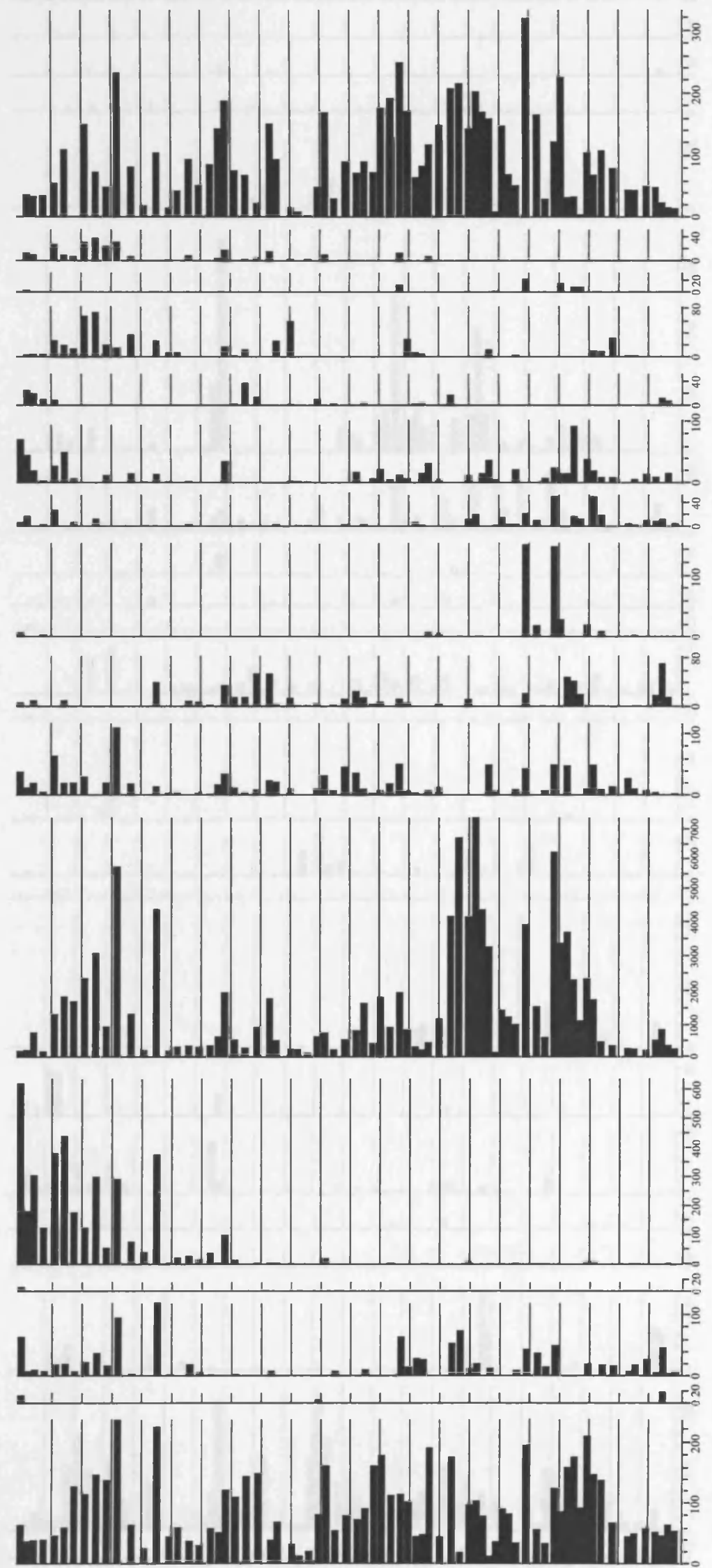

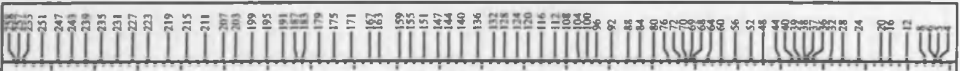

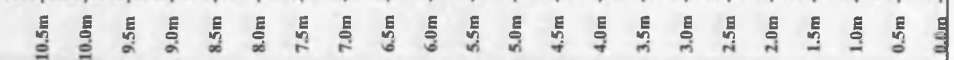

ב⿱ 
Multiplicisphaeridium forquiferum Multiplicisphaeridium fisherii Hoegklintia visbyense Quadratitum fantasticum Oppilatala ramusculosa Eupoikilofusa striatifera

Duvernaysphaera aranaides Buedingiisphaeridium ? globulosum Visbysphaera pirifera minor Visbysphaera gotlandica

Schismatosphaeridium perforatum Polygonium sp. B

Dilatisphaera quadratica Diexallophasis granulatispinosa Visbysphaera meson

Visbysphaera connnexa crispa

Tunisphaeridium tentaculaferum

Schismatosphaeridium longhopensis

Salopidium aff. granuliferum

Pulvinosphaeridium pulvinellum

Multiplicisphaeridium $\mathrm{cf}$ variabile

Multiplicisphaeridium mingusi Multiplicisphaeridium arbusculum Samples (DG00LK1.*) Height in metres

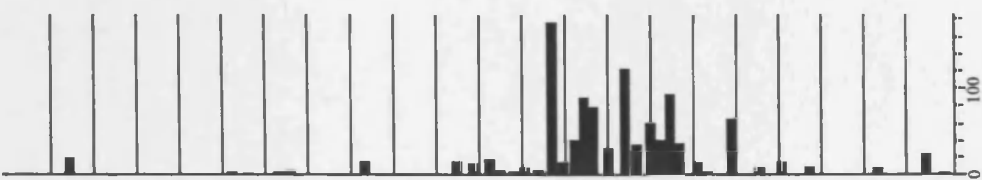

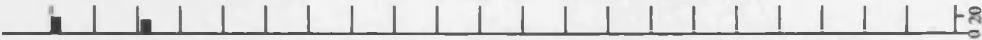

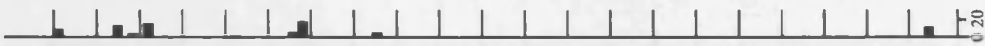

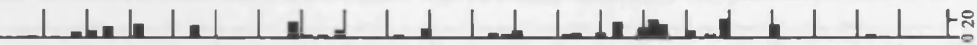
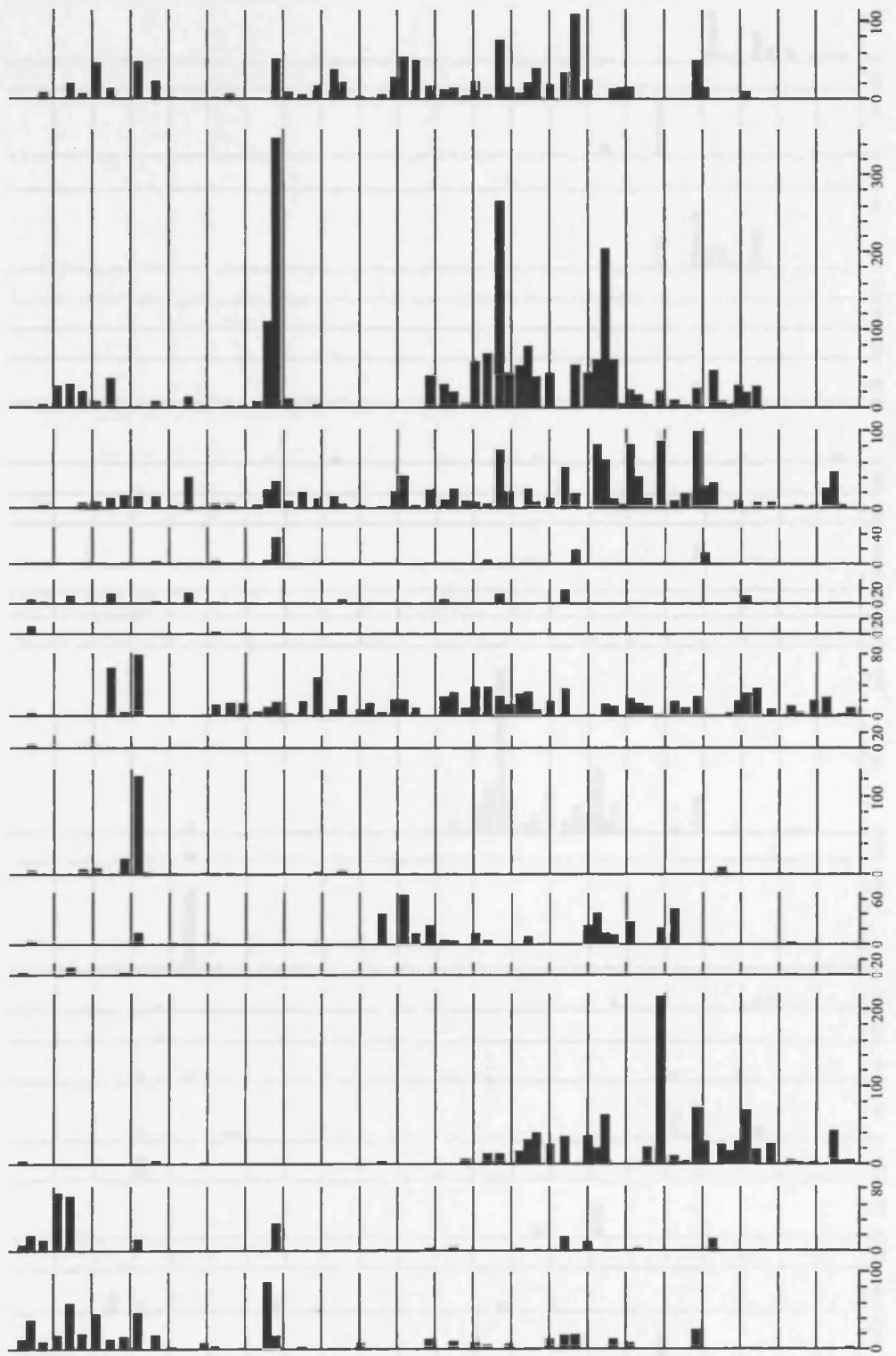

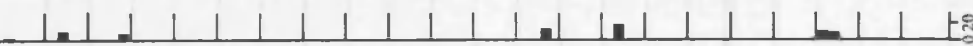

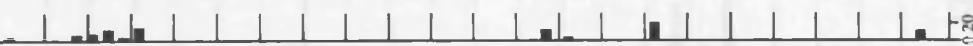

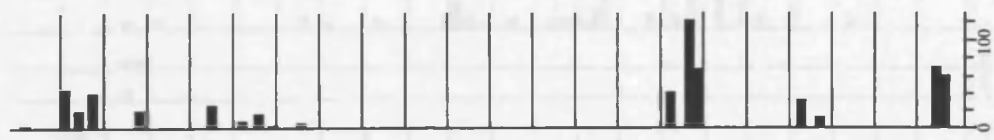

(1)

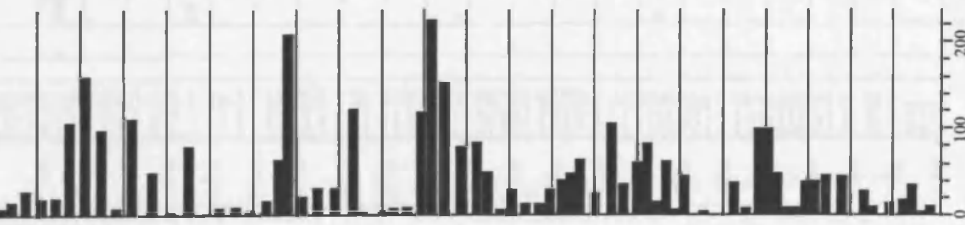

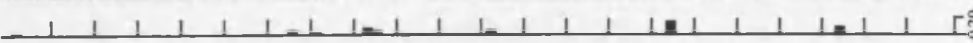

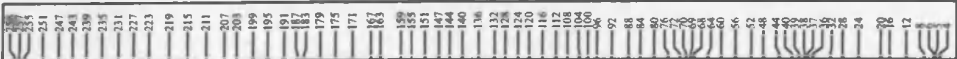

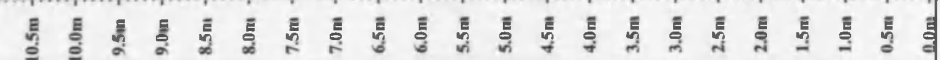


Deunfía monospinosa Buedingiisphaeridium? aff. globulosum Visbysphaera cf. gotlandica

Tylotopalla guapa Leiofusa kiryanovi

Pterospermella saturniforme

Oppilatala juvensis

Deunffia ramusculosa

Cymatiosphaera sp. B Leprotolypa gordonense Elektoriskos longispinosa

Onondagaella asymmetrica

Oppilatala grahni Veryhachium checkleyensis Oppilatala ramusculosa

Domasia quadraspinosa Domasia amphora Tylotopalla robustispinosa Salopidium fragelliforme

Visbysphaera pirifera pirifera Multiplicisphaeridium neahgae

Eupoikilofusa filifera

Oppilatala fermosa Multiplicisphaeridium rochesterense Gorgonisphaeridium succinum

Oppilatala insolita insolita

Multiplicisphaeridium osgoodense Leiofusa parvitatis Deunffia brevispinosa

Oppilatala singularis

Oppilatala insolita compacta Dictyotidium perlucidum Moyeria uticaensis

Visbysphaera oligofurcata Multiplicisphaeridium forquillum

Samples (DG00LK1.*)

Height in metres

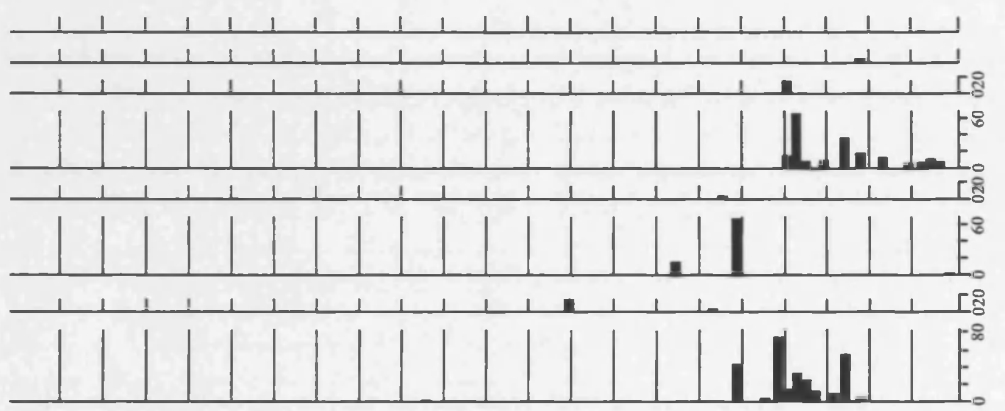
,
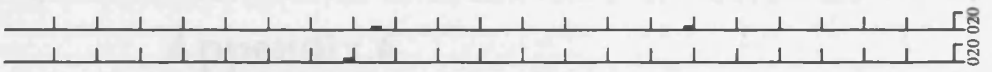

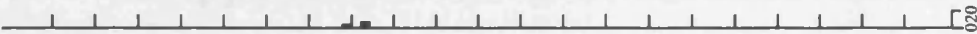

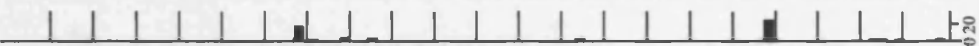
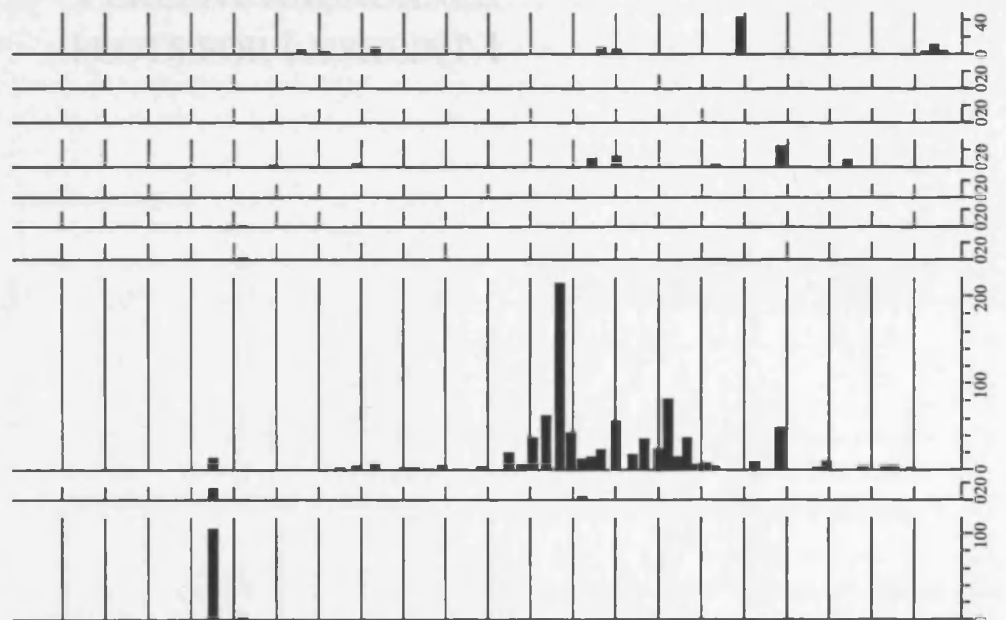

.

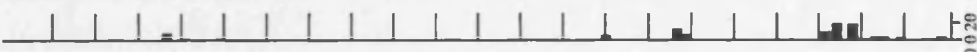

$\begin{array}{llllllllllllllllllllll}1 & 1 & 1 & 1 & 1 & 1 & 1 & 1 & 1 & 1 & 1 & 1 & 1 & 1 & 1 & 1 & 1 & 1 & 1 & 1 & \Gamma_{0}^{\circ}\end{array}$

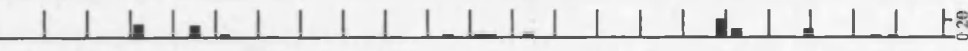

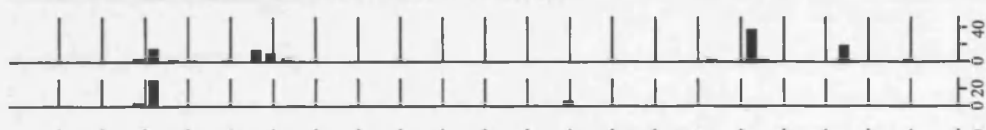

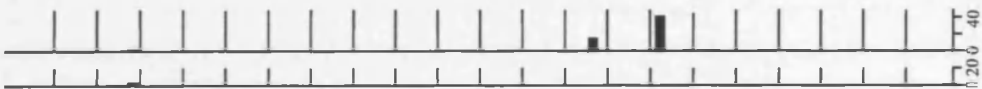

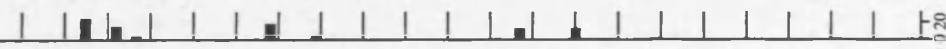

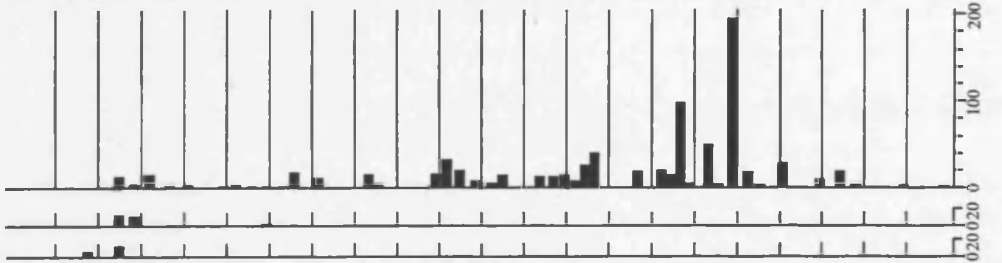

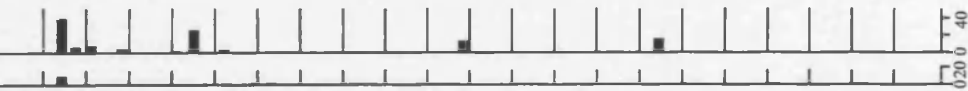

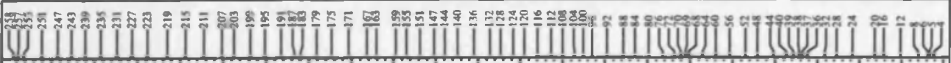

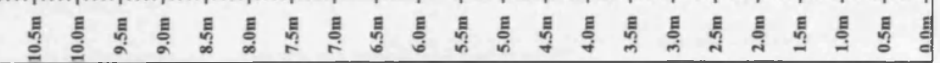


Appendix 6

PERCENT ABUNDANCE

PLOTS FOR LUSKLINT 1 


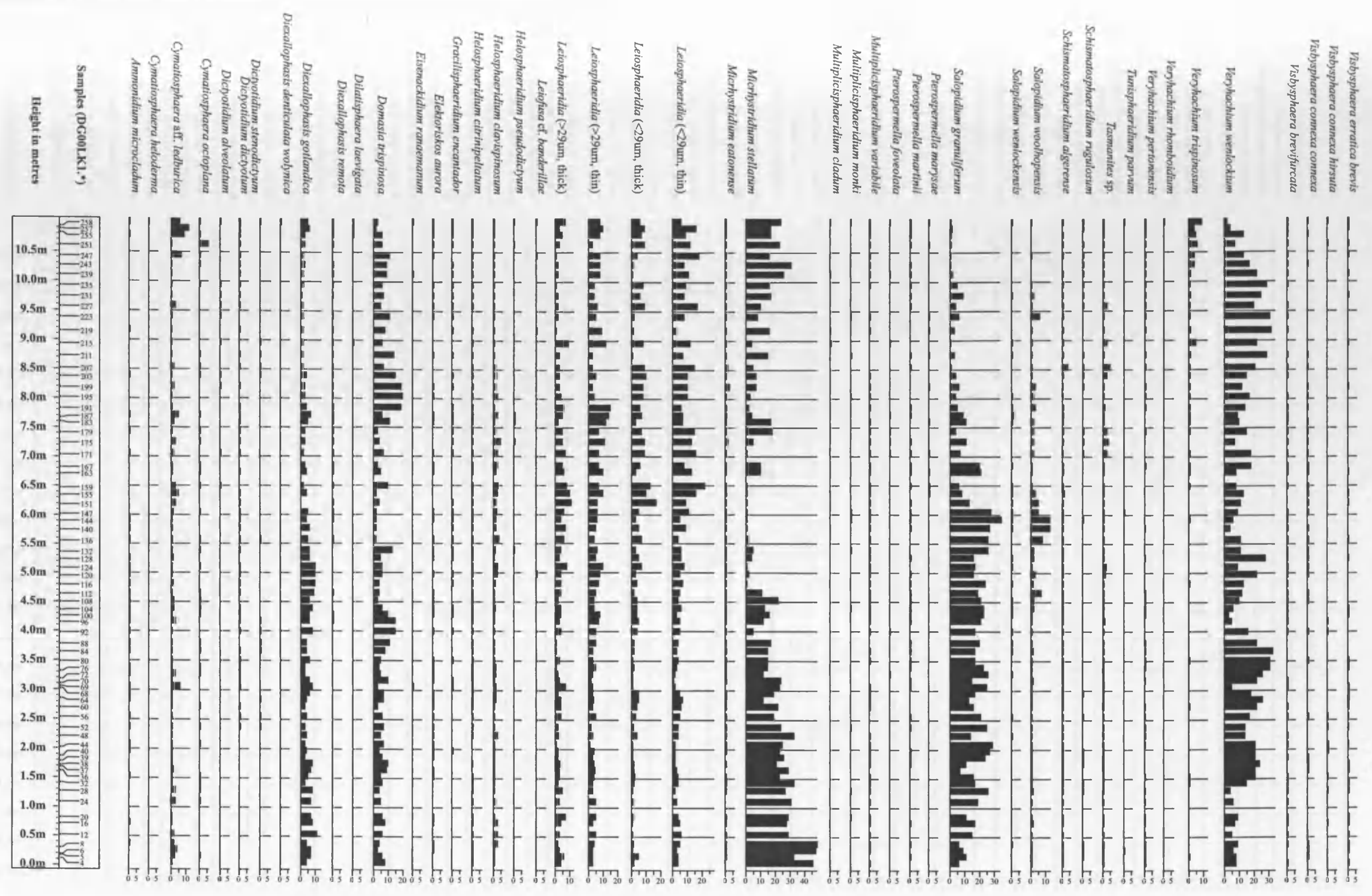

Appendix 6. Percentage abundance of palynomorphs, Lusklint 1. 
Deunffia monospinosa Buedingiisphaeridium? aff. globulosum Visbysphaera cf. gotlandica Tylotopalla guapa Leiofusa kinyanovi Pterospermella saturniforme

Oppilatala jwensis

Deunffia ramusculosa

Cymatiosphaera sp.B

Leprotolypa gordonense Elektoriskos longispinosa

Onondagaella asymmetrica Oppilatala grahni

Veryhachium checkleyensis

Oppilatala ramusculosa

Domasia quadraspinosa Domasia amphora

Tylotopalla robustispinosa

Salopidium fragelliforme

Visbysphaera pirifera pirifera

Multiplicisphaeridium neahgae Eupoikilofusa filifera

Oppilatala fermosa

Multiplicisphaeridium mochesterense

Gorgonisphaeridium succinum

Oppilatala insolita insolita

Multiplicisphaeridium osgoodense

Leiofusa panvitatis

Deunffia brevispinosa

Oppilatala singularis

Oppilatala insolita compacta

Dictyotidium perlucidum

Moyeria uticaensis

Visbysphaera oligofurcata

Multiplicisphaeridium forquillum Multiplicisphaeridium forquiferum

Multiplicisphaeridium fisherii

Hoegklintia visbyense

Quadratitum fantasticum

Oppilatala ramusculosa

Eupoikilofusa striatifera

Duvernaysphaera aranaides

Buedingiisphaeridium? globulosum

Visbysphaera pirifera minor

Visbysphaera gotlandica Schismatosphaeridium perforatum Polygonium sp. B

Dilatisphaera quadratica Diexallophasis gramulatispinosa Visbysphaera meson

Visbysphaera connnexa crispa

Tunisphaeridium tentaculaferum Schismatosphaeridium longhopensis

Salopidium aff. gramuliferum Pulvinosphaeridium pulvinellum Multiplicisphaeridium cf. variabile

Multiplicisphaeridium mingusi Multiplicisphaeridium arbusculum Micrhystridium sp. A

Micrhystridium irevikenensis

Hoegklintia digitata Domasia bispinosa

Dilatisphaera willierae

Dictyotidium faviforme

Visbysphaera microspinosa

Visbysphaera erratica brevis

Visbysphaera connexa hirsuta

Samples (DG00LK1.*)

Height in metre

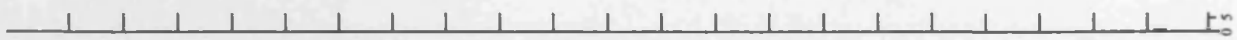

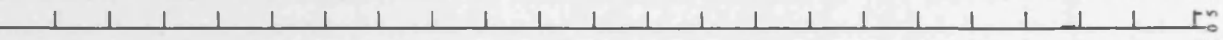

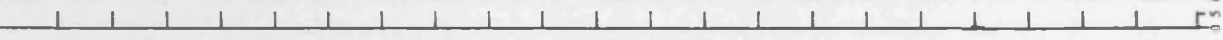

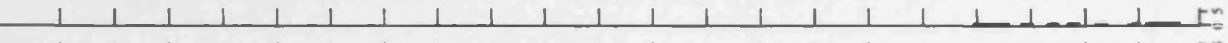

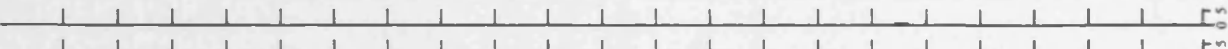

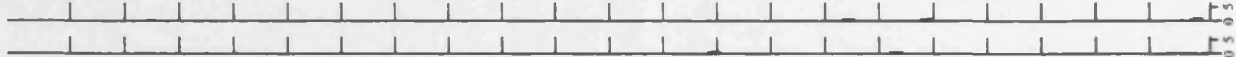

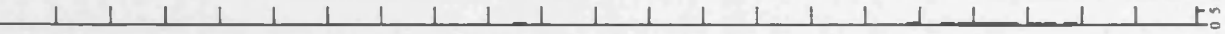

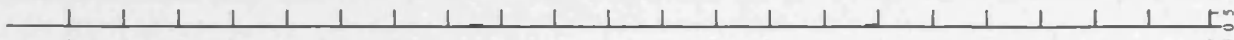

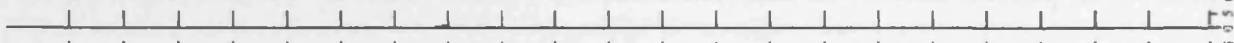

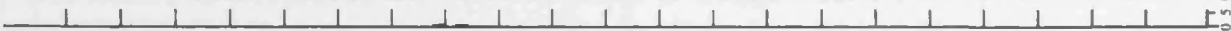

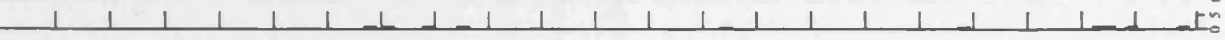

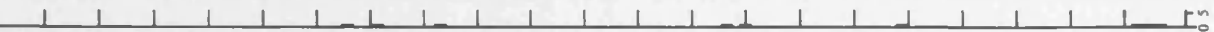

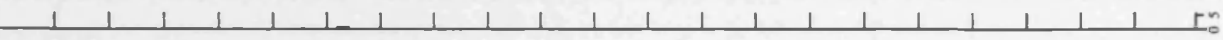

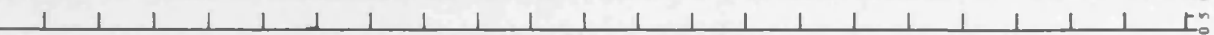

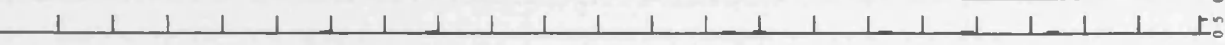

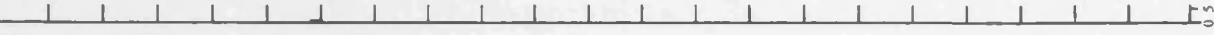

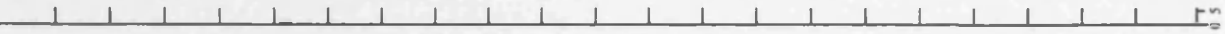

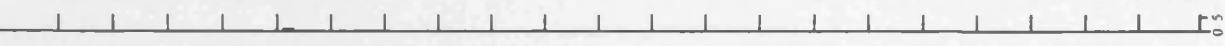

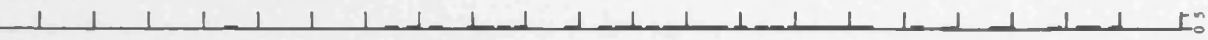

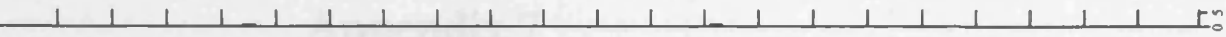

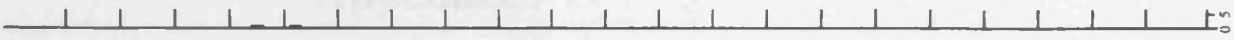

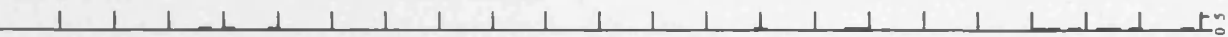

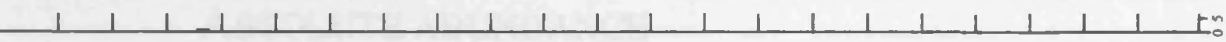

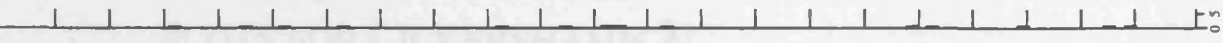

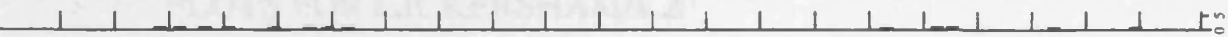

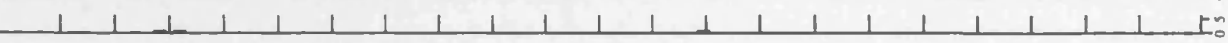

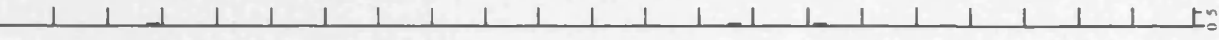

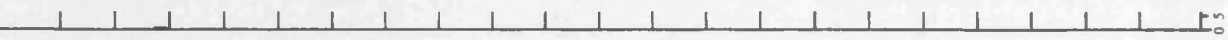

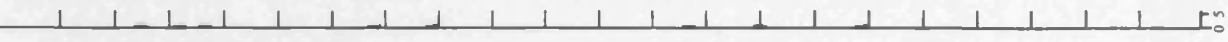

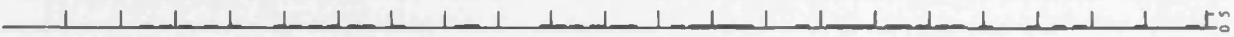

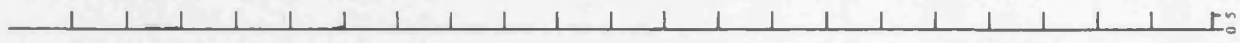

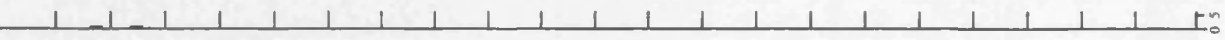

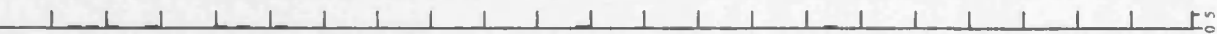

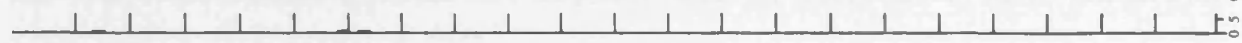

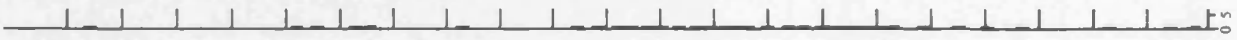

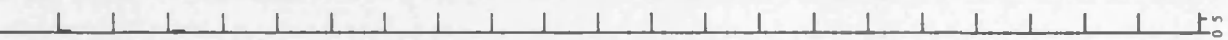

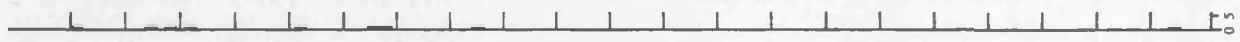

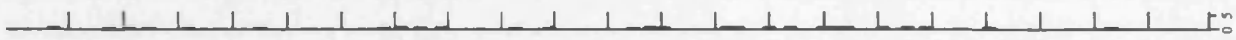

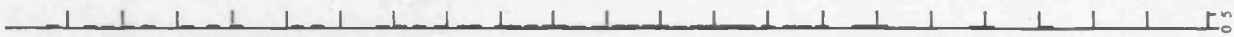

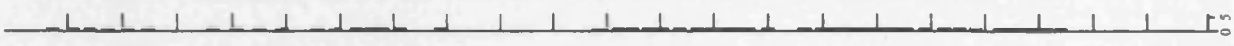

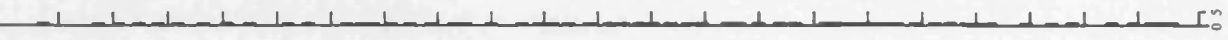

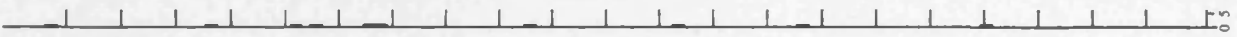

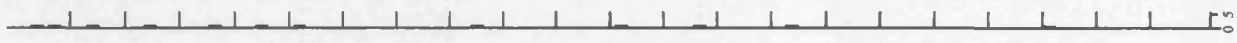

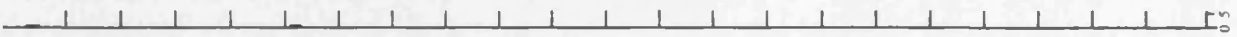

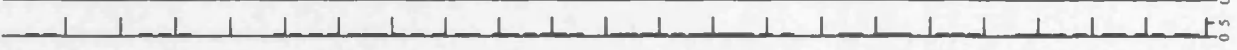

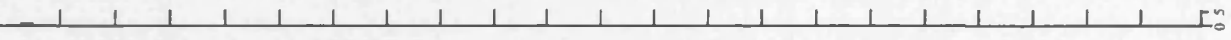

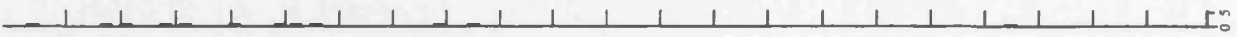

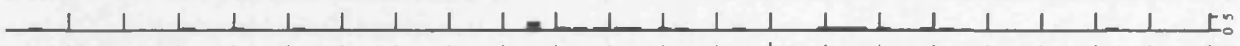

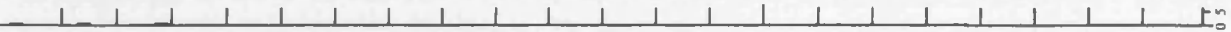

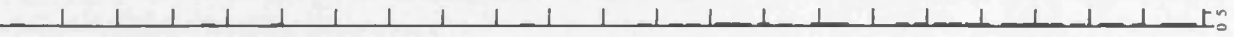

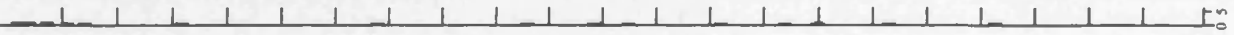

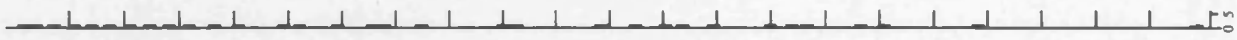

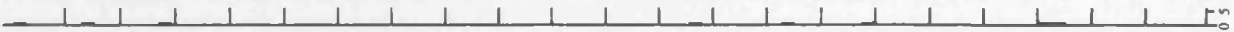

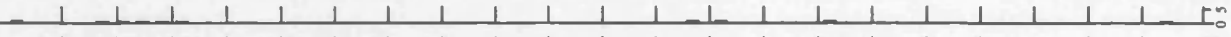

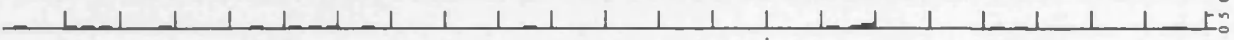

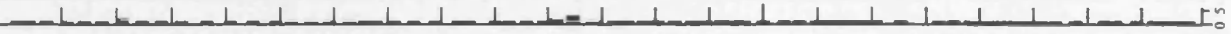

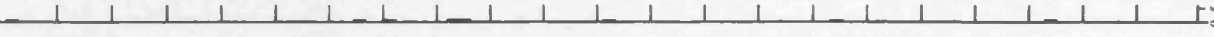

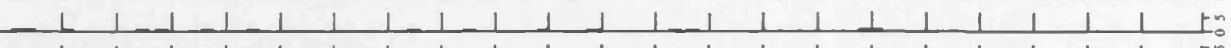

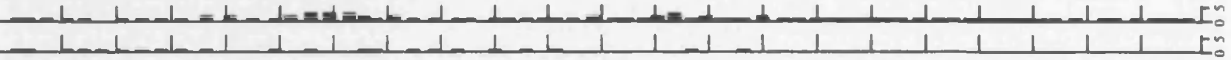

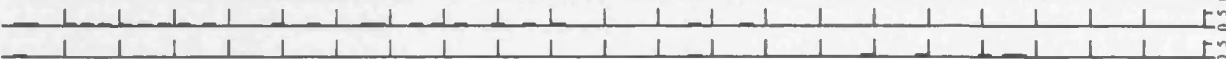

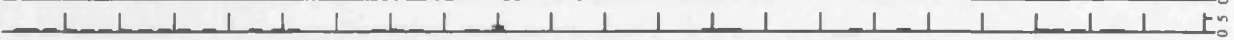

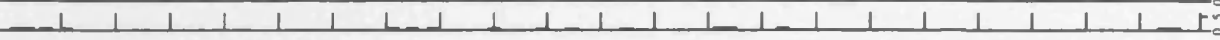

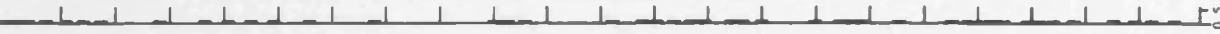

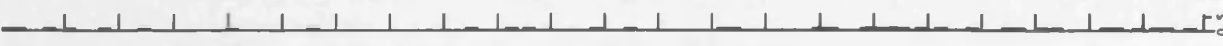

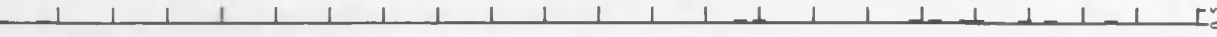

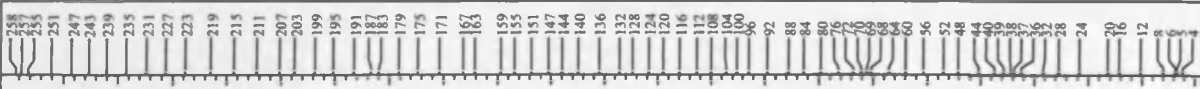

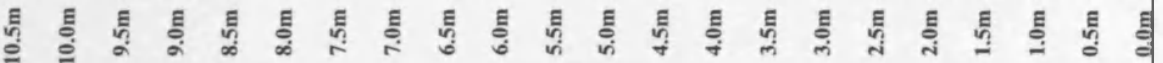




\section{Appendix 7}

ABSOLUTE ABUNDANCE PLOTS FOR LICKERSHAMN 2 
Leiosphaeridia (Lg Thn)>29um

Leiosphaeridia $(\mathrm{Lg}$ Thk) >29um Hoegklintia digitata

Helosphaeridium clavispinosum Helosphaeridium citrinipeltatum Eupoikilofusa striatifera Duvernaysphaera aranaides Domasia trispinosa Dilatisphaera willierae Dilatisphaera laevigata

Diexallophasis gotlandica Dictyotidium stenodictyum Dictyotidium faviforme Cymatiosphaera octoplana

Cymatiosphaera aff. ledburica

Samples (DG00LH2.*)

Height in metres
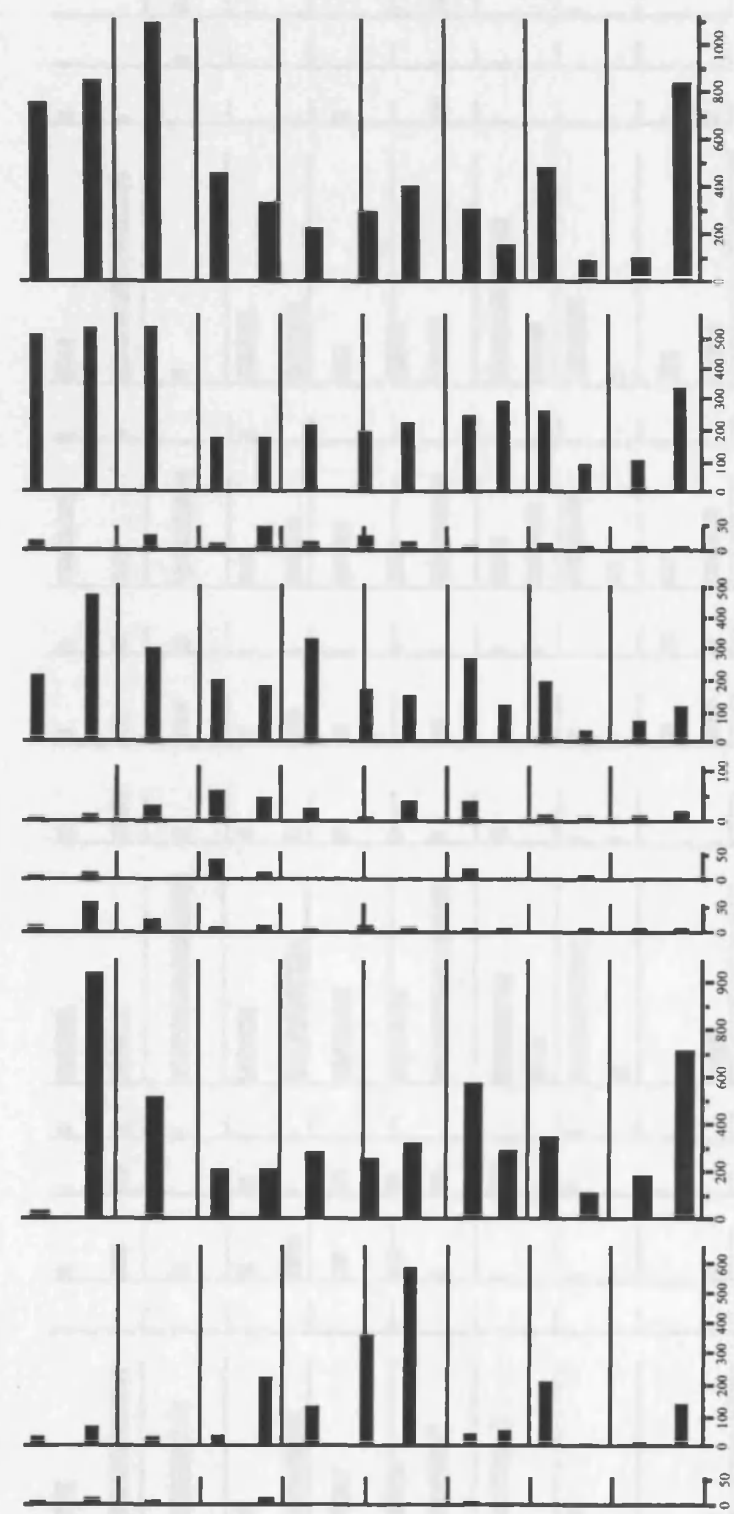

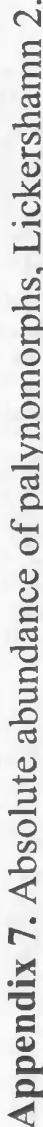


Visbysphaera microspinosa

Visbysphaera connexa hirsuta

Visbysphaera brevifurcata

Veryhachium wenlockium

Veryhachium trispinosum

Tasmanites $\mathrm{sp}$.

Schismatosphaeridium perforatum

Schismatosphaeridium algerense

Salopidium woolhopensis

Salopidium granuliferum

Oppilatala ramusculosa

Multiplicisphaeridium variabile

Multiplicisphaeridium mingusi Multiplicisphaeridium forquiferum

Micrhystridium stellatum

Micrhystridium irevikenensis

Micrhystridium eatonense

Leiosphaeridia (Sm Thn) <29um

Leiosphaeridia (Sm Thk) <29um

Samples (DG00LH2.*)

Height in metres
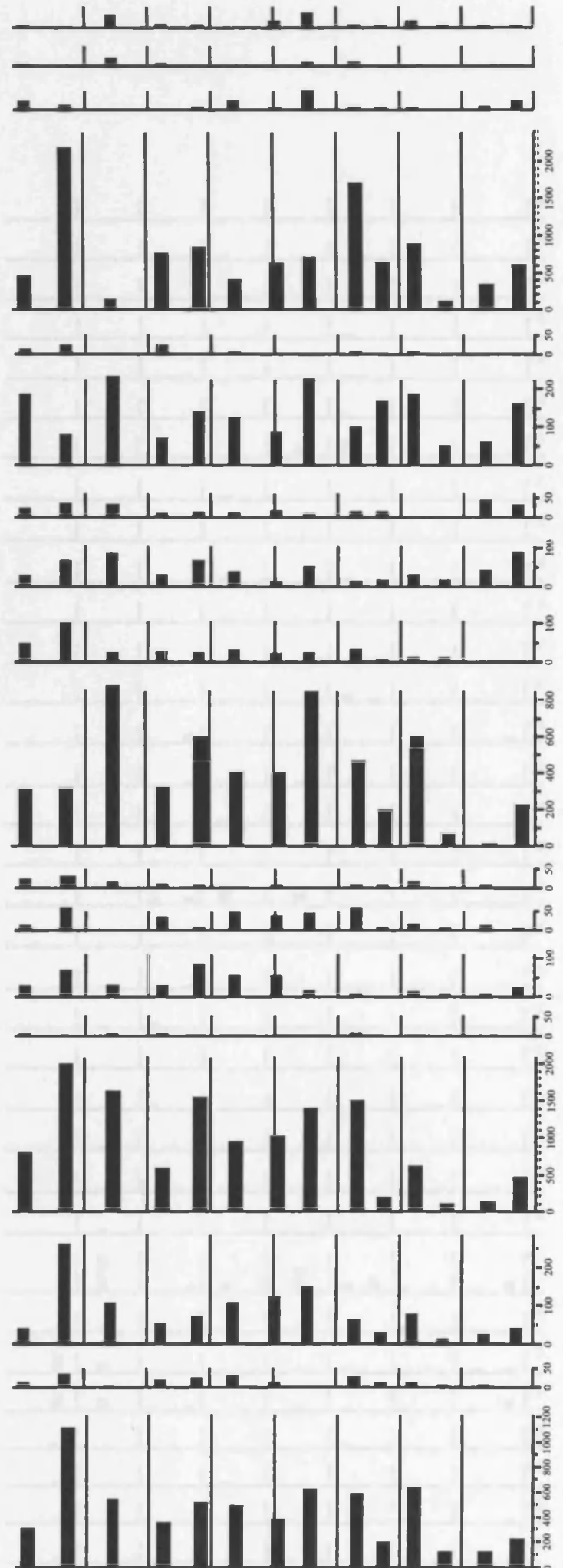

i

离

$\frac{0}{2}$

กิ

른

.

8
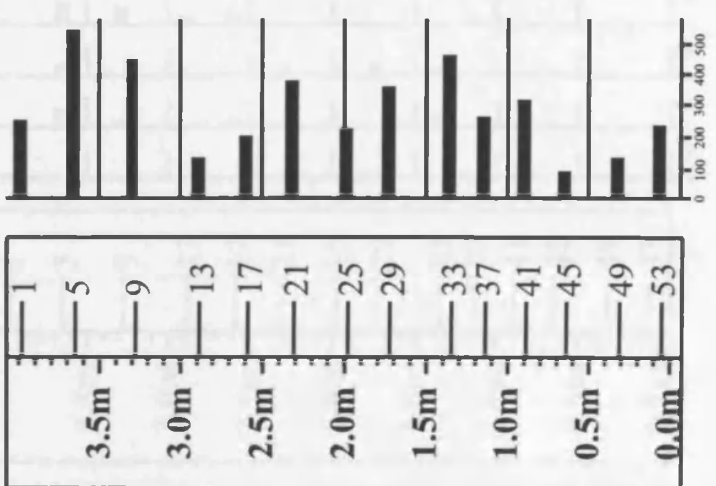
Visbysphaera oligofurcata

Salopidium wenlockensis Diexallophasis denticulata wolynica

Tunisphaeridium parvum

Pterospermella marysae

Hoegklintia corallina

Gracilisphaeridium encantador

Salopidium aff. granuliferum

Quadratitum fantasticum Pulvinosphaeridium pulvinellum

Oppilatala insolita insolita Multiplicisphaeridium $\mathrm{cf}$. variabile

Ammonidium microcladum

Visbysphaera connexa connexa

Diexallophasis granulatispinosa

Schismatosphaeridium longhopensis

Oppilatala insolita compacta

Micrhystridium sp. A

Elektoriskos aurora

Visbysphaera pirifera minor

Visbysphaera erratica brevis

Veryhachium pertonensis

Tunisphaeridium tentaculaferum

Multiplicisphaeridium forquillum

Gorgonisphaeridium succinum

Dictyotidium perlucidum

Dictyotidium dictyotum

Visbysphaera connnexa crispa

Pterospermella martinii

Schismatosphaeridium rugulosum

Oppilatala singularis

Onondagaella asymmetrica

Hoegklintia visbyense

Domasia quadraspinosa

Dilatisphaera quadratica

Diexallophasis remota

Cymatiosphaera sp. B

Visbysphaera pirifera pirifera

Samples (DG00LH2.*)

Height in metres

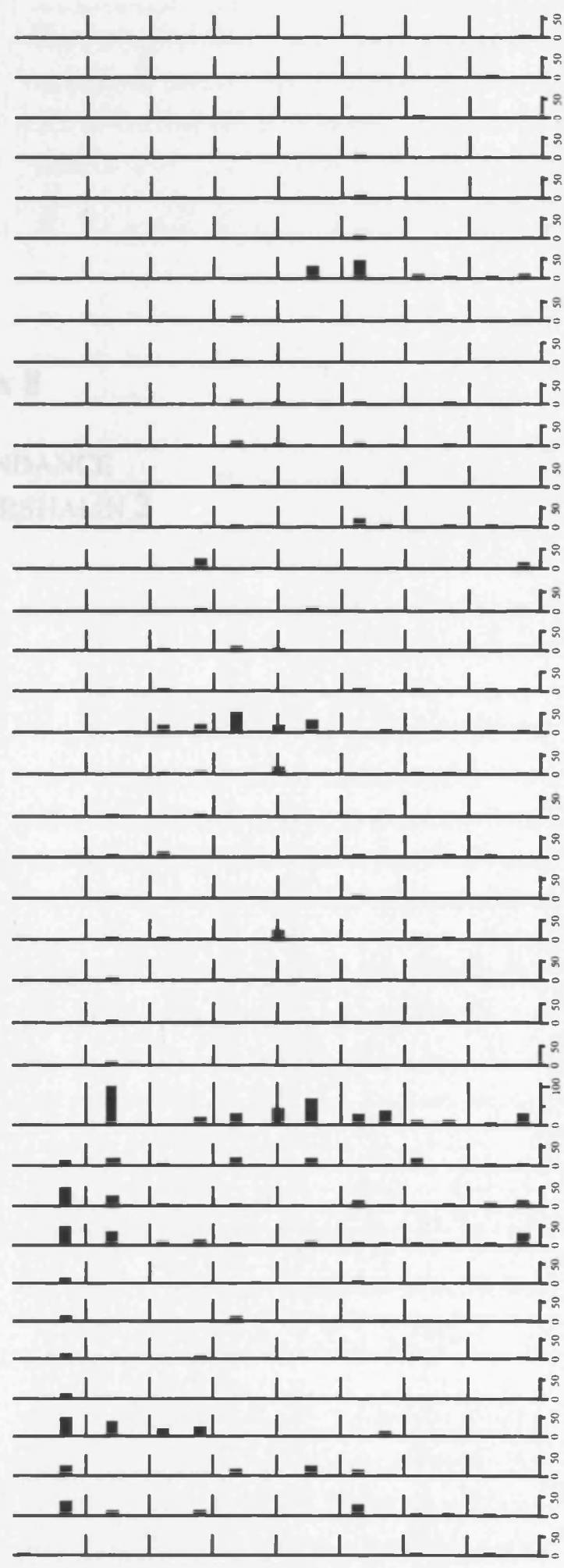

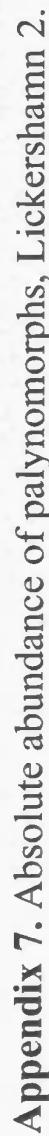


Appendix 8

PERCENT ABUNDANCE

PLOTS FOR LICKERSHAMN 2 
Hoegklintia visbyense

Domasia quadraspinosa

Dilatisphaera quadratica

Diexallophasis remota

Cymatiosphaera sp. B

Visbysphaera pirifera pirifera

Visbysphaera microspinosa

Visbysphaera connexa hirsuta

Visbysphaera brevifurcata

Veryhachium wenlockium

Veryhachium trispinosum Tasmanites sp.

Schismatosphaeridium perforatum

Schismatosphaeridium algerense

Salopidium woolhopensis

Salopidium granuliferum

Oppilatala ramusculosa

Multiplicisphaeridium variabile

Multiplicisphaeridium mingusi

Multiplicisphaeridium forquiferum

Micrhystridium stellatum

Micrhystridium irevikenensis

Micrhystridium eatonense Leiosphaeridia (Sm Thn) <29um Leiosphaeridia (Sm Thk) <29um

Leiosphaeridia (Lg Thn) >29um Leiosphaeridia (Lg Thk) >29um Hoegklintia digitata Helosphaeridium clavispinosum Helosphaeridium citrinipeltatum

Eupoikilofusa striatifera

Duvernaysphaera aranaides

Domasia trispinosa Dilatisphaera willierae

Dilatisphaera laevigata Diexallophasis gotlandica

Dictyotidium stenodictyum

Dictyotidium faviforme

Cymatiosphaera octoplana

Cymatiosphaera aff. ledburica

Samples (DG00LH2.*)

Height in metres

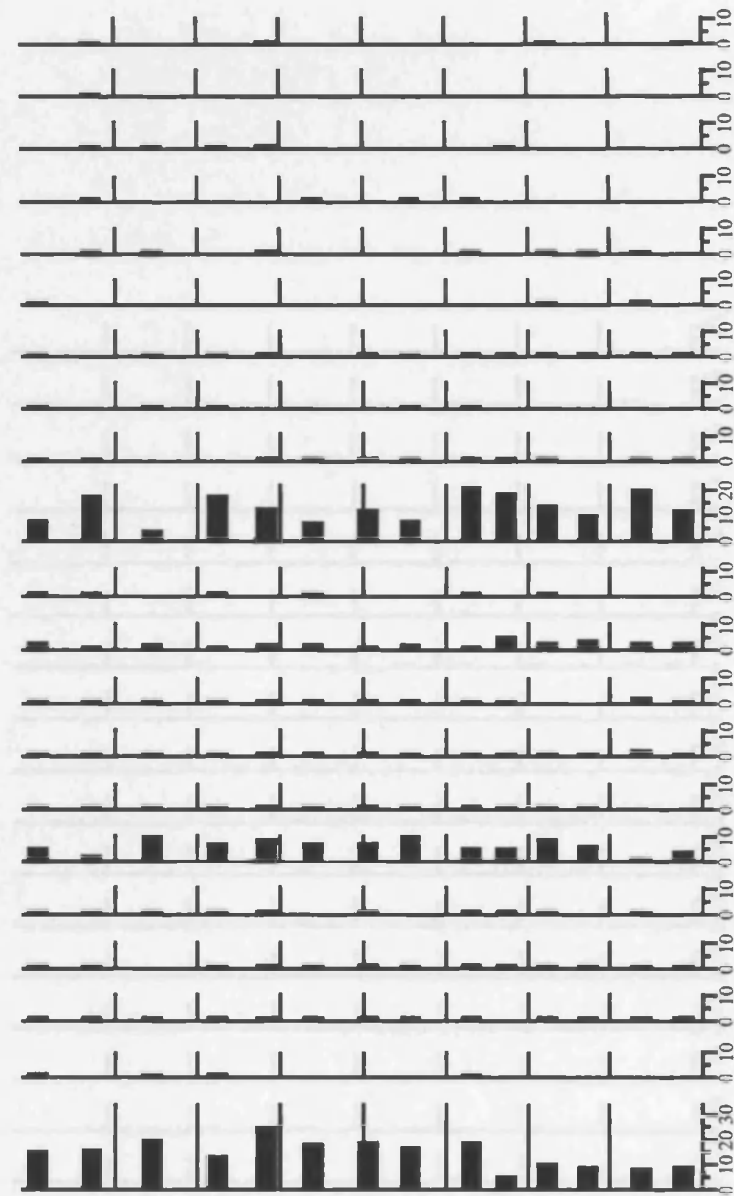

$-1-1-1-1-1-1-1-F_{0}^{\circ}$

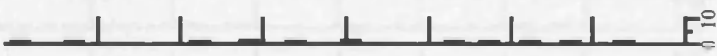

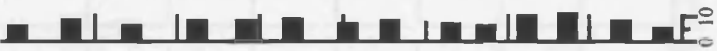

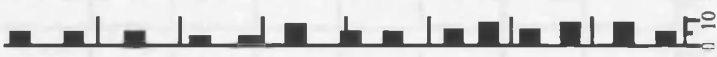

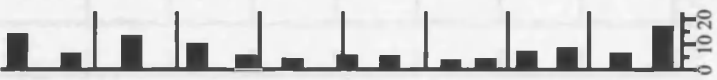

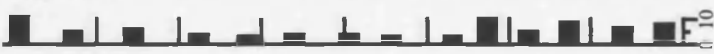

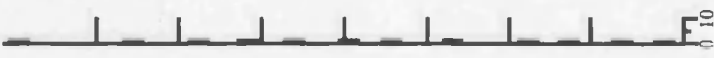

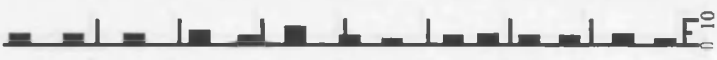

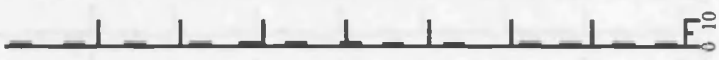

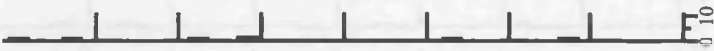

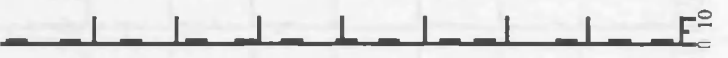

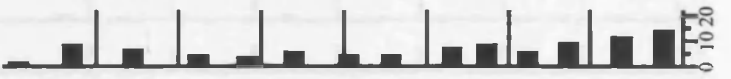

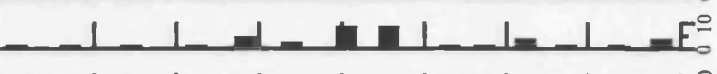

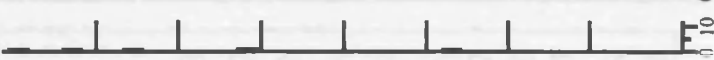

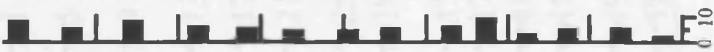

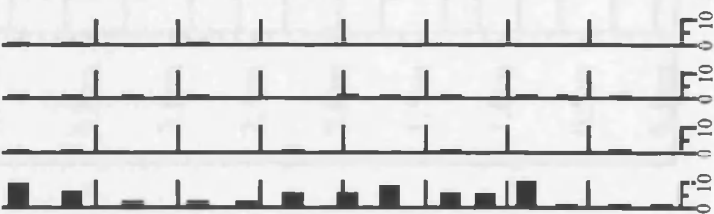

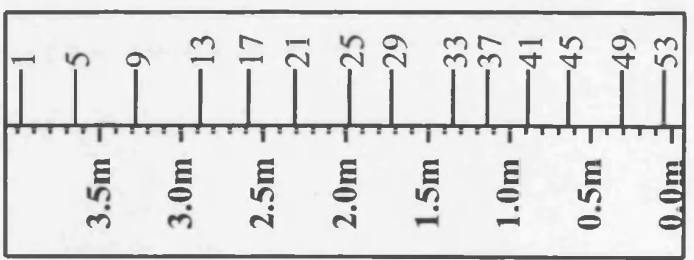


Visbysphaera oligofurcata

Salopidium wenlockensis

Diexallophasis denticulata wolynica

Tunisphaeridium parvum

Pterospermella marysae

Hoegklintia corallina

Gracilisphaeridium encantador

Salopidium aff. granuliferum

Quadratitum fantasticum

Pulvinosphaeridium pulvinellum

Oppilatala insolita insolita

Multiplicisphaeridium $\mathrm{cf}$ variabile

Ammonidium microcladum

Visbysphaera connexa connexa

Diexallophasis granulatispinosa

Schismatosphaeridium longhopensis

Oppilatala insolita compacta

Micrhystridium sp. A

Elektoriskos aurora

Visbysphaera pirifera minor

Visbysphaera erratica brevis

Veryhachium pertonensis Tunisphaeridium tentaculaferum Multiplicisphaeridium forquillum

Gorgonisphaeridium succinum

Dictyotidium perlucidum

Dictyotidium dictyotum

Visbysphaera connnexa crispa

Schismatosphaeridium rugulosum

Pterospermella martinii

Oppilatala singularis

Onondagaella asymmetrica

Samples (DG00LH2.*)

Height in metres

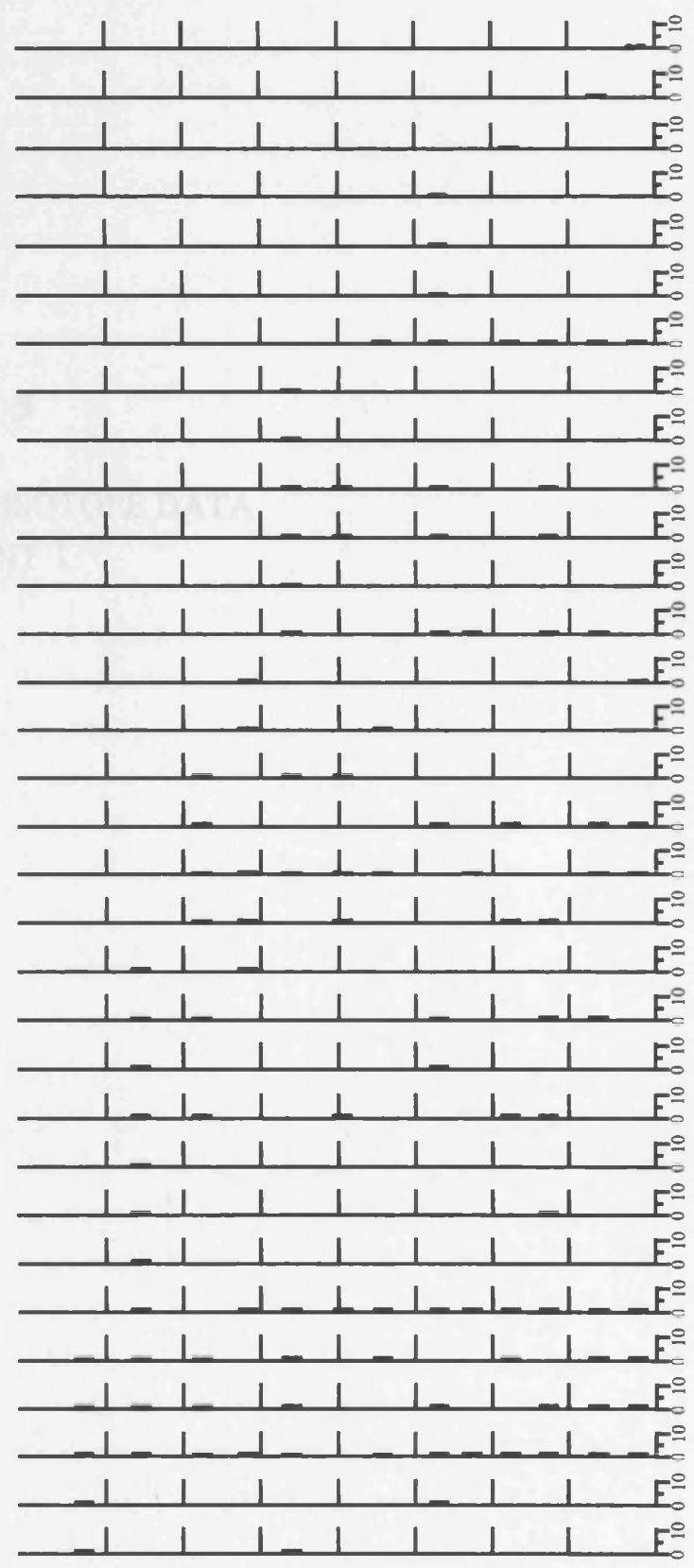

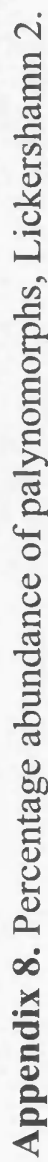




\section{Appendix 9}

CARBON AND OXYGEN ISOTOPE DATA FOR LUSKLINT 1 


\begin{tabular}{|c|c|c|}
\hline $\begin{array}{l}\text { Depth in metres above } \\
\text { base of Lusklint } 1\end{array}$ & \begin{tabular}{|l|} 
Stable $C^{13}$ \\
value
\end{tabular} & $\begin{array}{l}\text { Stable } \mathrm{O}^{10} \\
\text { value }\end{array}$ \\
\hline 10.590 & 3.478 & 10.740 \\
\hline 10.535 & 3.616 & 10.685 \\
\hline 10.465 & 4.325 & 10.615 \\
\hline 10.400 & 4.200 & 10.550 \\
\hline 10.360 & 3.676 & 10.510 \\
\hline 10.300 & 3.584 & 10.450 \\
\hline 10.260 & 3.591 & 10.410 \\
\hline 10.205 & 3.804 & 10.355 \\
\hline 10.160 & 4.453 & 10.310 \\
\hline 10.065 & 3.906 & 10.215 \\
\hline 10.035 & 4.098 & 10.185 \\
\hline 10.015 & 3.681 & 10.165 \\
\hline 9.965 & 3.617 & 10.115 \\
\hline 9.915 & 3.314 & 10.065 \\
\hline 9.845 & 3.848 & 9.995 \\
\hline 9.785 & 3.772 & 9.935 \\
\hline 9.735 & 3.181 & 9.885 \\
\hline 9.665 & 3.091 & 9.815 \\
\hline 9.625 & 3.822 & 9.775 \\
\hline 9.520 & 3.481 & 9.670 \\
\hline 9.475 & 3.658 & 9.625 \\
\hline 9.435 & 3.897 & 9.585 \\
\hline 9.390 & 3.177 & 9.540 \\
\hline 9.245 & 3.491 & 9.395 \\
\hline 9.170 & 3.335 & 9.320 \\
\hline 9.090 & 3.597 & 9.240 \\
\hline 9.070 & 3.691 & 9.220 \\
\hline 8.985 & 3.788 & 9.135 \\
\hline 8.925 & 3.506 & 9.075 \\
\hline 8.850 & 2.898 & 9.000 \\
\hline 8.845 & 3.709 & 8.995 \\
\hline 8.755 & 3.514 & 8.905 \\
\hline 8.685 & 3.376 & 8.835 \\
\hline 8.655 & 3.535 & 8.805 \\
\hline 8.620 & 3.000 & 8.770 \\
\hline 8.555 & 3.378 & 8.705 \\
\hline 8.495 & 2.627 & 8.645 \\
\hline 8.440 & 3.250 & 8.590 \\
\hline 8.375 & 3.015 & 8.525 \\
\hline 8.345 & 3.013 & 8.495 \\
\hline 8.240 & 3.357 & 8.390 \\
\hline 8.190 & 3.754 & 8.340 \\
\hline 8.160 & 3.111 & 8.310 \\
\hline 8.140 & 3.136 & 8.290 \\
\hline 8.110 & 3.031 & 8.260 \\
\hline 8.070 & 3.376 & 8.220 \\
\hline 7.930 & 3.718 & 8.080 \\
\hline 7.930 & 3.996 & 8.080 \\
\hline 7.820 & 3.342 & 7.970 \\
\hline 7.715 & 3.584 & 7.865 \\
\hline 7.700 & 3.457 & 7.850 \\
\hline 7.680 & 3.154 & 7.830 \\
\hline 7.600 & 2.587 & 7.750 \\
\hline 7.550 & 3.264 & 7.700 \\
\hline 7.465 & 2.686 & 7.615 \\
\hline 7.415 & 2.729 & 7.565 \\
\hline 7.340 & 3.043 & 7.490 \\
\hline 7.300 & 2.794 & 7.450 \\
\hline 7.235 & 2.944 & 7.385 \\
\hline 7.215 & 3.590 & 7.365 \\
\hline 7.180 & 2.803 & 7.330 \\
\hline 7.120 & 2.938 & 7.270 \\
\hline 7.100 & 3.260 & 7.250 \\
\hline 7.000 & 2.694 & 7.150 \\
\hline 6.985 & 2.865 & 7.135 \\
\hline 6.930 & 2.300 & 7.080 \\
\hline 6.815 & 3.167 & 6.965 \\
\hline 6.760 & 2.890 & 6.910 \\
\hline 6.615 & 2.738 & 6.765 \\
\hline 6.560 & 3.260 & 6.710 \\
\hline 6.500 & 1.969 & 6.650 \\
\hline 6.475 & 2.756 & 6.625 \\
\hline 6.435 & 3.247 & 6.585 \\
\hline 6.425 & 2.292 & 6.575 \\
\hline 6.410 & 3.214 & 6.560 \\
\hline
\end{tabular}

\begin{tabular}{|c|c|c|}
\hline $\begin{array}{l}\text { Depth in metres above } \\
\text { base of Lusklint } 1\end{array}$ & \begin{tabular}{|l|l}
$\begin{array}{l}\text { Stable } \mathrm{C}^{13} \\
\text { value }\end{array}$ & $\mathrm{V}$ \\
\end{tabular} & \begin{tabular}{|l|}
$\begin{array}{l}\text { Stable } 0^{18} \\
\text { value }\end{array}$ \\
\end{tabular} \\
\hline \begin{tabular}{|c|}
6.330 \\
\end{tabular} & 2.678 & 6.480 \\
\hline 6.330 & 3.206 & 6.480 \\
\hline 6.280 & 2.755 & 6.430 \\
\hline 6.250 & 2.350 & 6.400 \\
\hline 6.230 & 2.736 & 6.380 \\
\hline 6.210 & 2.879 & 6.360 \\
\hline 6.190 & 2.846 & 6.340 \\
\hline 6.140 & 3.027 & 6.290 \\
\hline 6.105 & 2.307 & 6.255 \\
\hline 6.080 & 2.144 & 6.230 \\
\hline 6.030 & 1.970 & 6.180 \\
\hline 5.970 & 1.997 & 6.120 \\
\hline 5.780 & 2.501 & 5.930 \\
\hline 5.740 & 2.243 & 5.890 \\
\hline 5.700 & 2.639 & 5.850 \\
\hline 5.700 & 2.035 & 5.850 \\
\hline 5.700 & 2.311 & 5.850 \\
\hline 5.700 & 2.337 & 5.850 \\
\hline 5.665 & 2.547 & 5.815 \\
\hline 5.630 & 1.893 & 5.780 \\
\hline 5.605 & 2.303 & 5.755 \\
\hline 5.575 & 2.776 & 5.725 \\
\hline 5.500 & 2.200 & 5.650 \\
\hline 5.500 & 2.276 & 5.650 \\
\hline 5.500 & 2.381 & 5.650 \\
\hline 5.500 & 2.168 & 5.650 \\
\hline 5.500 & 2.192 & 5.650 \\
\hline 5.465 & 2.193 & 5.615 \\
\hline 5.410 & 2.091 & 5.560 \\
\hline 5.390 & 2.023 & 5.540 \\
\hline 5.390 & 1.853 & 5.540 \\
\hline 5.355 & 1.770 & 5.505 \\
\hline 5.330 & 2.180 & 5.480 \\
\hline 5.300 & 2.010 & 5.450 \\
\hline 5.273 & 2.077 & 5.423 \\
\hline 5.195 & 1.657 & 5.345 \\
\hline 5.175 & 1.642 & 5.325 \\
\hline 5.155 & 1.943 & 5.305 \\
\hline 5.140 & 1.901 & 5.290 \\
\hline 5.060 & 1.623 & 5.210 \\
\hline 4.930 & 1.719 & 5.080 \\
\hline 4.900 & 1.962 & 5.050 \\
\hline 4.845 & 1.644 & 4.995 \\
\hline 4.830 & 1.653 & 4.980 \\
\hline 4.815 & 1.921 & 4.965 \\
\hline 4.815 & 1.923 & 4.965 \\
\hline 4.815 & 1.855 & 4.965 \\
\hline 4.815 & 1.870 & 4.965 \\
\hline 4.815 & 2.607 & 4.965 \\
\hline 4.790 & 2.365 & 4.940 \\
\hline 4.790 & 1.244 & 4.940 \\
\hline 4.790 & 1.268 & 4.940 \\
\hline 4.790 & 0.424 & 4.940 \\
\hline 4.790 & 0.915 & 4.940 \\
\hline 4.765 & 1.494 & 4.915 \\
\hline 4.765 & 1.798 & 4.915 \\
\hline 4.765 & 1.482 & 4.915 \\
\hline 4.765 & 2.386 & 4.915 \\
\hline 4.765 & 1.538 & 4.915 \\
\hline 4.740 & 1.678 & 4.890 \\
\hline 4.735 & 1.720 & 4.885 \\
\hline 4.735 & 2.078 & 4.885 \\
\hline 4.735 & 2.406 & 4.885 \\
\hline 4.735 & 2.247 & 4.885 \\
\hline 4.735 & 1.927 & 4.885 \\
\hline 4.645 & 1.674 & 4.795 \\
\hline 4.510 & 1.616 & 4.660 \\
\hline 4.510 & 1.644 & 4.660 \\
\hline 4.440 & 1.752 & 4.590 \\
\hline 4.400 & 1.584 & 4.550 \\
\hline 4.400 & 1.885 & 4.550 \\
\hline 4.330 & 1.637 & 4.480 \\
\hline 4.305 & 2.359 & 4.455 \\
\hline 4.265 & 1.841 & 4.415 \\
\hline 4.260 & 2.090 & 4.410 \\
\hline
\end{tabular}

Appendix 9. Carbon and Oxygen isotope data for Lusklint 1, provided by Corfield and Siveter 


\begin{tabular}{|c|c|c|}
\hline $\begin{array}{l}\text { Depth in metres above } \\
\text { base of Lusklint } 1\end{array}$ & \begin{tabular}{|l}
$\begin{array}{l}\text { Stable } \mathrm{C}^{13} \\
\text { value }\end{array}$ \\
\end{tabular} & $\begin{array}{l}\begin{array}{l}\text { Stable } 0^{18} \\
\text { value }\end{array} \\
\end{array}$ \\
\hline 4.215 & 0.936 & 4.365 \\
\hline 4.190 & 1.964 & 4.340 \\
\hline 4.175 & 1.996 & 4.325 \\
\hline 4.150 & 1.035 & 4.300 \\
\hline 4.060 & 1.575 & 4.210 \\
\hline 3.980 & 1.829 & 4.130 \\
\hline 3.860 & 1.677 & 4.010 \\
\hline 3.760 & 1.758 & 3.910 \\
\hline 3.660 & 1.688 & 3.810 \\
\hline 3.440 & 1.231 & 3.590 \\
\hline 3.380 & 1.696 & 3.530 \\
\hline 3.330 & 1.585 & 3.480 \\
\hline 3.265 & 1.347 & 3.415 \\
\hline 3.225 & 1.425 & 3.375 \\
\hline 3.085 & 1.953 & 3.235 \\
\hline 3.010 & 2.036 & 3.160 \\
\hline 2.930 & 1.961 & 3.080 \\
\hline 2.900 & 1.086 & 3.050 \\
\hline 2.850 & 1.458 & 3.000 \\
\hline 2.820 & 1.127 & 2.970 \\
\hline 2.743 & 1.574 & 2.893 \\
\hline 2.673 & 1.781 & 2.823 \\
\hline 2.673 & 1.498 & 2.823 \\
\hline 2.628 & 1.711 & 2.778 \\
\hline 2.583 & 1.768 & 2.733 \\
\hline 2.545 & 1.606 & 2.695 \\
\hline 2.515 & 1.738 & 2.665 \\
\hline 2.435 & 1.264 & 2.585 \\
\hline 2.345 & 1.590 & 2.495 \\
\hline 2.250 & 1.217 & 2.400 \\
\hline 2.145 & 1.793 & 2.295 \\
\hline 2.030 & 1.284 & 2.180 \\
\hline 1.970 & 1.539 & 2.120 \\
\hline 1.910 & 1.366 & 2.060 \\
\hline 1.870 & 1.549 & 2.020 \\
\hline 1.810 & 1.247 & 1.960 \\
\hline 1.730 & 1.195 & 1.880 \\
\hline 1.730 & 1.190 & 1.880 \\
\hline 1.670 & 1.184 & 1.820 \\
\hline 1.645 & 1.538 & 1.795 \\
\hline 1.635 & 1.457 & 1.785 \\
\hline 1.595 & 1.575 & 1.745 \\
\hline 1.555 & 1.606 & 1.705 \\
\hline 1.555 & 1.631 & 1.705 \\
\hline 1.555 & 1.440 & 1.705 \\
\hline 1.555 & 1.445 & 1.705 \\
\hline 1.555 & 1.467 & 1.705 \\
\hline 1.555 & 1.603 & 1.705 \\
\hline 1.525 & 1.287 & 1.675 \\
\hline 1.505 & 1.486 & 1.655 \\
\hline 1.480 & 1.043 & 1.630 \\
\hline 1.475 & 1.516 & 1.625 \\
\hline 1.430 & 1.640 & 1.580 \\
\hline 1.385 & 1.535 & 1.535 \\
\hline 1.340 & 1.545 & 1.490 \\
\hline 1.340 & 1.564 & 1.490 \\
\hline 1.230 & 1.056 & 1.380 \\
\hline 1.180 & 1.626 & 1.330 \\
\hline 1.105 & 1.504 & 1.255 \\
\hline 1.070 & 1.518 & 1.220 \\
\hline 1.050 & 1.499 & 1.200 \\
\hline 1.030 & 1.590 & 1.180 \\
\hline 1.030 & 1.504 & 1.180 \\
\hline 1.005 & 1.467 & 1,155 \\
\hline 0.965 & 1.516 & 1.115 \\
\hline 0.960 & 1.583 & 1.110 \\
\hline 0.895 & 1.557 & 1.045 \\
\hline 0.870 & 1.487 & 1.020 \\
\hline 0.845 & 1.582 & 0.995 \\
\hline 0.845 & 1.757 & 0.995 \\
\hline 0.800 & 1.535 & 0.950 \\
\hline 0.780 & 1.401 & 0.930 \\
\hline 0.775 & 1.450 & 0.925 \\
\hline 0.775 & 1.517 & 0.925 \\
\hline 0.760 & 1.493 & 0.910 \\
\hline
\end{tabular}

\begin{tabular}{|c|c|c|}
\hline $\begin{array}{l}\text { Depth in metres above } \\
\text { base of Lusklint } 1\end{array}$ & \begin{tabular}{|l|} 
Stable $\mathrm{C}^{\mathrm{i3}}$ \\
value
\end{tabular} & $\begin{array}{l}\text { Stable } \mathrm{O}^{18} \\
\text { value }\end{array}$ \\
\hline 0.738 & 1.481 & 0.888 \\
\hline 0.738 & 1.136 & 0.888 \\
\hline 0.695 & 1.416 & 0.845 \\
\hline 0.655 & 1.313 & 0.805 \\
\hline 0.655 & 1.542 & 0.805 \\
\hline 0.620 & 1.577 & 0.770 \\
\hline 0.580 & 0.751 & 0.730 \\
\hline 0.560 & 1.415 & 0.710 \\
\hline 0.520 & 1.335 & 0.670 \\
\hline 0.490 & 1.339 & 0.640 \\
\hline 0.445 & 1.604 & 0.595 \\
\hline 0.400 & 1.268 & 0.550 \\
\hline 0.350 & 1.309 & 0.500 \\
\hline 0.300 & 1.436 & 0.450 \\
\hline 0.295 & 1.347 & 0.445 \\
\hline 0.240 & 1.593 & 0.390 \\
\hline 0.240 & 1.625 & 0.390 \\
\hline 0.180 & 1.179 & 0.330 \\
\hline 0.115 & 1.550 & 0.265 \\
\hline 0.070 & 1.221 & 0.220 \\
\hline 0.010 & 1.264 & 0.160 \\
\hline 0.005 & 1.278 & 0.155 \\
\hline 0.005 & 1.234 & 0.155 \\
\hline-0.020 & 1.607 & 0.130 \\
\hline-0.060 & 1.587 & 0.090 \\
\hline-0.105 & 1.513 & 0.045 \\
\hline-0.150 & 1.347 & 0.000 \\
\hline-0.250 & 1.483 & -0.100 \\
\hline-0.350 & 1.503 & -0.200 \\
\hline-0.450 & 1.514 & -0.300 \\
\hline-0.550 & 1.462 & -0.400 \\
\hline-0.650 & 1.287 & -0.500 \\
\hline-0.750 & 1.508 & -0.600 \\
\hline-0.850 & 1.517 & -0.700 \\
\hline-0.950 & 1.534 & -0.800 \\
\hline-1.050 & 1.534 & -0.900 \\
\hline-1.150 & 1.489 & -1.000 \\
\hline-1.250 & 1.525 & -1.100 \\
\hline-1.350 & 1.519 & -1.200 \\
\hline-1.450 & 1.622 & -1.300 \\
\hline-1.550 & 1.544 & -1.400 \\
\hline-1.650 & 1.600 & -1.500 \\
\hline-1.750 & 1.562 & -1.600 \\
\hline-1.850 & 1.664 & -1.700 \\
\hline-1.950 & 1.720 & -1.800 \\
\hline-2.050 & 1.628 & -1.900 \\
\hline-2.150 & 1.518 & -2.000 \\
\hline-2.250 & 1.529 & -2.100 \\
\hline-2.350 & 1.549 & -2.200 \\
\hline-2.385 & 1.379 & -2.235 \\
\hline-2.385 & 1.509 & -2.235 \\
\hline-2.450 & 1.511 & -2.300 \\
\hline-2.550 & 1.402 & -2.400 \\
\hline-2.570 & 1.453 & -2.420 \\
\hline-2.630 & 1.540 & -2.480 \\
\hline-2.650 & 1.330 & -2.500 \\
\hline-2.670 & 1.585 & -2.520 \\
\hline-2.740 & 1.459 & -2.590 \\
\hline-2.750 & 1.451 & -2.600 \\
\hline-2.790 & 1.528 & -2.640 \\
\hline-2.850 & 1.391 & -2.700 \\
\hline-2.950 & 1.583 & -2.800 \\
\hline-3.050 & 1.524 & -2.900 \\
\hline-3.150 & 1.558 & -3.000 \\
\hline-3.250 & 1.577 & -3.100 \\
\hline-3.350 & 1.586 & -3.200 \\
\hline-3.450 & 1.575 & -3.300 \\
\hline-3.550 & 1.531 & -3.400 \\
\hline-3.650 & 1.708 & -3.500 \\
\hline-3.750 & 1.557 & -3.600 \\
\hline-3.850 & 1.645 & -3.700 \\
\hline-3.950 & 1.698 & -3.800 \\
\hline-4.050 & 1.499 & -3.900 \\
\hline-4.150 & 1.623 & -4.000 \\
\hline-4.150 & 1.170 & -4.000 \\
\hline
\end{tabular}

Appendix 9. Carbon and Oxygen isotope data for Lusklint 1, provided by Corfield and Siveter 


\begin{tabular}{|c|c|c|}
\hline $\begin{array}{l}\text { Depth in metres above } \\
\text { base of Lusklint } 1\end{array}$ & \begin{tabular}{|l|}
$\begin{array}{l}\text { Stable } \mathrm{C}^{13} \\
\text { value }\end{array}$ \\
\end{tabular} & \begin{tabular}{|l|} 
Stable $0^{18}$ \\
value
\end{tabular} \\
\hline-4.250 & 1.520 & -4.100 \\
\hline-4.350 & 1.522 & -4.200 \\
\hline-4.450 & 1.391 & -4.300 \\
\hline-4.550 & 1.404 & -4.400 \\
\hline-4.650 & 1.364 & -4.500 \\
\hline-4.750 & 1.565 & -4.600 \\
\hline-4.850 & 1.444 & -4.700 \\
\hline-4.950 & 1.510 & -4.800 \\
\hline-5.050 & 1.579 & -4.900 \\
\hline-5.150 & 1.496 & .5 .000 \\
\hline-5.250 & 1.311 & .5 .100 \\
\hline .5 .350 & 1.489 & -5.200 \\
\hline-5.450 & 1.543 & -5.300 \\
\hline-5.550 & 1.621 & -5.400 \\
\hline-5.650 & 1.905 & -5.500 \\
\hline-5.850 & 1.296 & -5.700 \\
\hline-5.950 & 1.621 & -5.800 \\
\hline-5.950 & 1.529 & -5.800 \\
\hline-6.050 & 1.434 & -5.900 \\
\hline-6.150 & 1.534 & -6.000 \\
\hline-6.250 & 1.529 & -6.100 \\
\hline-6.350 & 1.574 & -6.200 \\
\hline-6.450 & 1.541 & -6.300 \\
\hline-6.550 & 1.836 & -6.400 \\
\hline-6.650 & 1.628 & -6.500 \\
\hline-6.750 & 1.704 & -6.600 \\
\hline-6.850 & 1.616 & -6.700 \\
\hline-6.950 & 2.069 & -6.800 \\
\hline-7.050 & 1.655 & -6.900 \\
\hline-7.150 & 1.621 & -7.000 \\
\hline-7.250 & 1.524 & -7.100 \\
\hline-7.350 & 1.658 & -7.200 \\
\hline-7.450 & 1.560 & -7.300 \\
\hline-7.550 & 1.816 & -7.400 \\
\hline-7.650 & 1.595 & -7.500 \\
\hline-7.750 & 1.826 & -7.600 \\
\hline-7.850 & 1.647 & -7.700 \\
\hline-7.950 & 1.671 & -7.800 \\
\hline-8.050 & 1.677 & -7.900 \\
\hline-8.150 & 1.920 & -8.000 \\
\hline-8.710 & 1.872 & -8.560 \\
\hline-8.978 & 1.808 & -8.828 \\
\hline-9.055 & 1.836 & -8.905 \\
\hline
\end{tabular}


Plates 
Fig.

Dictyotidium alveolatum (Kiryanov, 1978) Le Hérissé, 1989

DG00LK1.259npg1-S29, 3, Upper Visby Beds, x 750. Specimen

showing typical extent of pyritization prior to nitric acid treatment.

Schismatosphaeridium algerense Cramer \& Díez, 1976a DG00LK1.259npg1-P28, Upper Visby Beds, x 750. Specimen showing typical extent of pyritization prior to nitric acid treatment.

\section{Recent organic debris}

Deionised water slide 3-J 52, 2, x 400.

Deionised water slide 3-D48, 1, x 400. Debris showing a cell structure

Deionised water slide 2-V 47, 1, x 400. Debris showing pseudoprocesses radiating from a central body.

Pterospermella martinii Cramer, 1966a

DG00LK1.187npg1-S38, Upper Visby Beds, x 750. Photograph showing a pale unheated specimen.

DG00LK1.187ckd1-N39, 1, Upper Visby Beds, x 750.

Photograph showing a dark specimen, which has undergone heating.

Gracilisphaeridium encantador (Cramer, 1970) ex Eisenack et

$$
\text { al., } 1973
$$

DG00LK1.187ckd1-K34, 1, Upper Visby Beds, x 750.

Photograph showing a pale unheated specimen. heating. 
PLATE 1
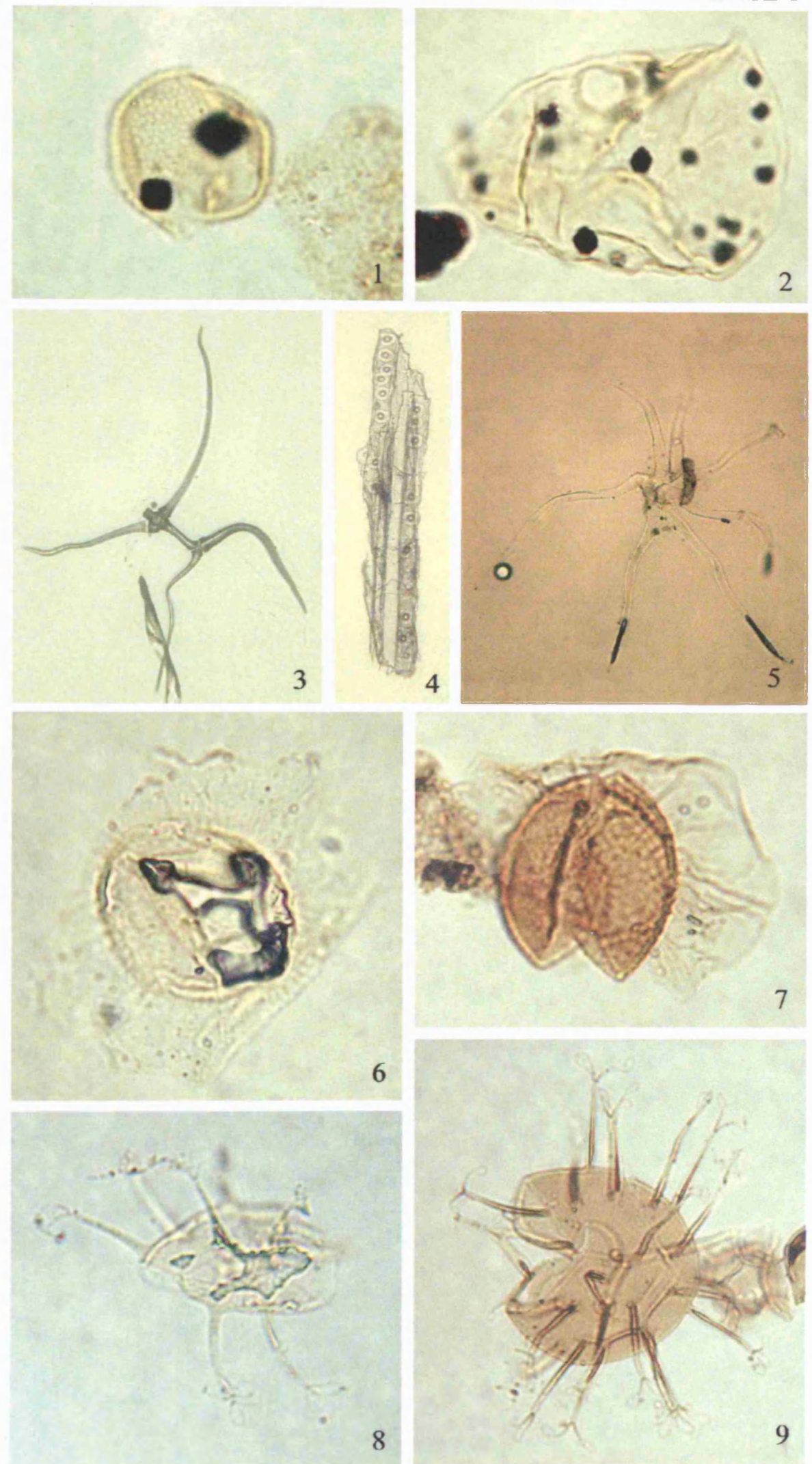
Fig.

Page

Micrhystridium stellatum Deflandre, 1945

DG00LK1.21npg1-T47, Lower Visby Beds, x 1000.

Pulvinosphaeridium pulvinellum Eisenack, 1954

DG00LH2.25npg1-H46, 4, Lower Visby Beds, x 600.

Tasmanites sp.

DG00LK1.258ckd 1-K34, 1, Upper Visby Beds, x 1000.

Schismatosphaeridium rugulosum Dorning, 1981

DG00LH2.9npg1-F34, 2, Upper Visby Beds, x 1000. Specimen showing coarse globular ornament on the vesicle surface.

Pterospermella marysae Le Hérissé, 1989

DG00LK1.258ckd 1-Q35, Upper Visby Beds, x 1000. Specimen showing wide equatorial flange.

Salopidium granuliferum (Downie 1959) Dorning, 1981

DG00LK1.100npg1-R34, 2, Lower Visby Beds, x 1000.

Specimen showing simple process form and a granulate vesicle.

Oppilatala insolita insolita Cramer \& Diez 1972

DG00LK1.219npg1-R45, Upper Visby Beds, x 1000. Specimen showing complex branching pattern.

Eupoikilofusa striatifera Cramer, 1964a

DG00LK1.100npg1-N40, Lower Visby Beds, x 1000. Specimen showing fusiform vesicle shape.

Veryhachium wenlockium (Downie, 1959) Stockmans \&

Willière, $1962 \mathrm{~b}$

DG00LK1.258 ckd 1, R34/4, Upper Visby Beds, x 1000.

Specimen showing triangular vesicle. 
PLATE 2
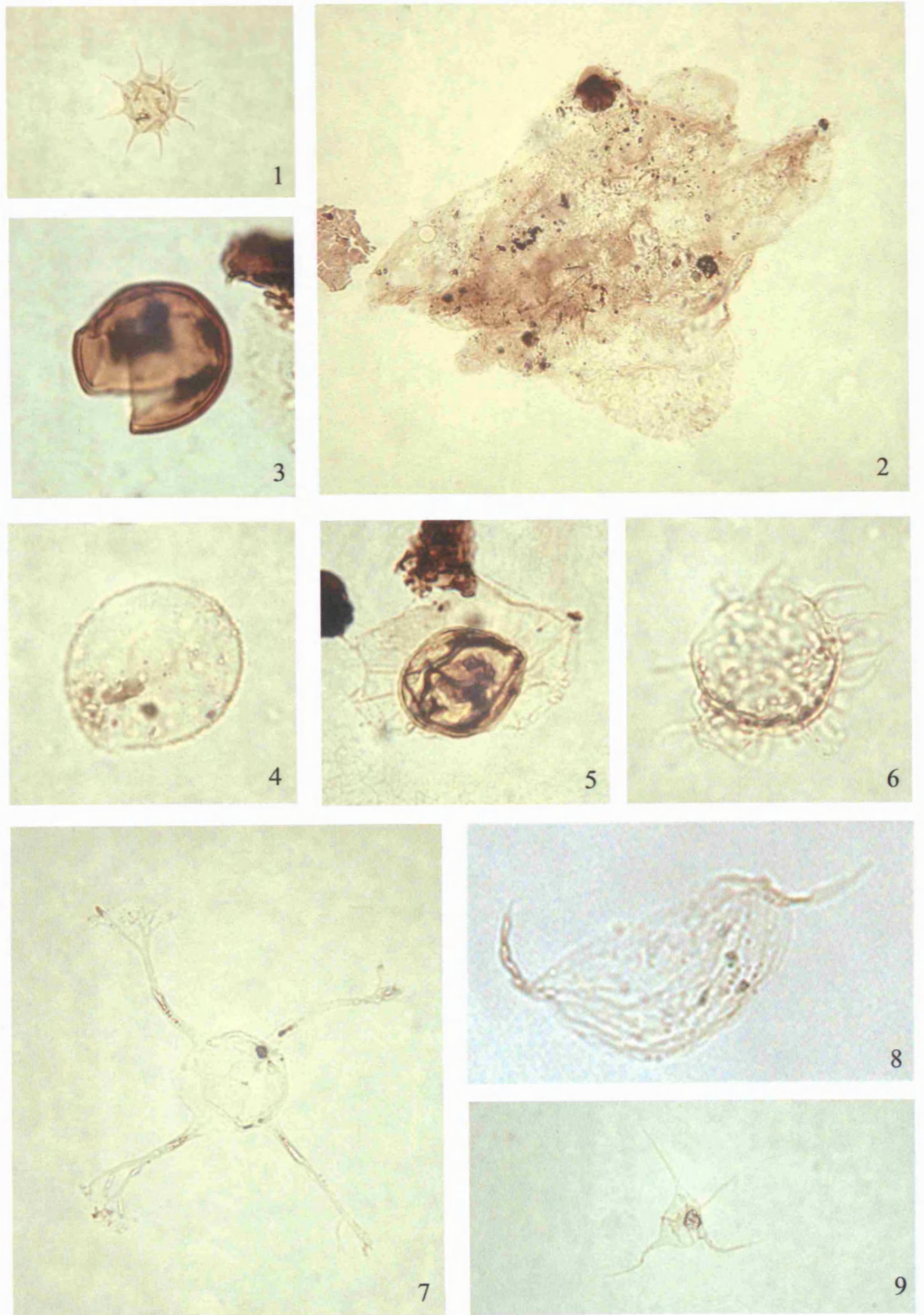
Fig.

1 DG00LK1.258ckd1-O43, 1, Upper Visby Beds. x 750.

2 DG00LK1.258ckd1-S32, Upper Visby Beds, $\mathrm{x} 750$.

12 DG00LK1.120-J6, (SEM), Lower Visby Beds, $x 750$.

13 DG00LK1.112-J12, (SEM), Lower Visby Beds. x 750.

Cymatiosphaera octoplana Downie, 1959

3 DG00LK1.24npg1-L41, 1, Lower Visby Beds, x 750.

4 DG00LK1.48npg3-Q36, Lower Visby Beds, x 750.

$5 \quad$ DG00LK1.20npg1-N39, 4, Lower Visby Beds x 750.

6 DG00LK1.207npg1-T35, 1, Lower Visby Beds x 750. Specimen showing characters that closely follow the description of " $C$. prismatica" (Le Hérissé 1989 pp. 76), which is now combined with C. octoplana. DG00LK1.120-L5, (SEM) Lower Visby Beds, x 750.

Cymatiosphaera sp. B Le Hérissé, 1989

7 DG00LK2.9npg1-T45, 2, Upper Visby Beds, 750.

8 DG00LK1.258npg1ckd-N42, 4, Upper Visby Beds x 750.

Cymatiosphaera heloderma Cramer \& Díez, 1972 DG00LK1.257-T10, (SEM) Upper Visby Beds, $x$ 750. Specimen showing an unopened thickened linear excystment structure. This specimen shows some similarities to the structures in the fields of $C$. mariae Le Hérissé, 1989, but here these are only an over-development of the foveolate structure.

11 DG00LK1.255-M3, (SEM), Upper Visby Beds, $x$ 750. Specimen similar to C. octoplana, but with a foveolate, not granulate, vesicle.

Duvernaysphaera aranaides (Cramer, 1964b) Cramer \& Díez, 1972

14 DG00LK1.128npg1-O41, 1, Lower Visby Beds, x 750.

15 DG00LK1.144npg1-L41, Upper Visby Beds, $\mathrm{x} 750$. 
PLATE 3
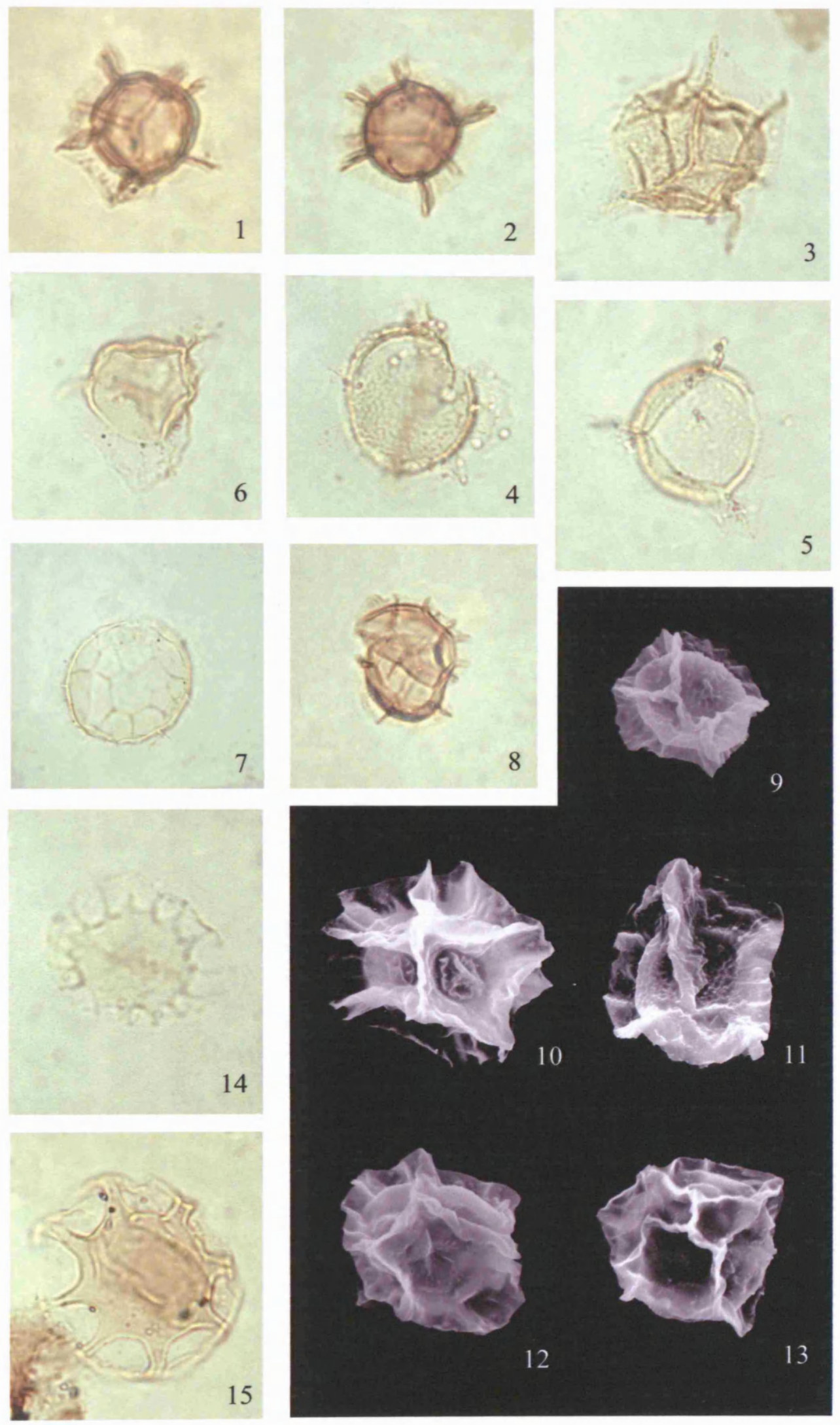
Fig.

1 DG00LK1.171npg1-Q41, Upper Visby Beds, $\mathrm{x}$ 750. This specimen is similar to $D$. dictyotum (fig. 4), but possesses smaller and more numerous fields (about twice as many as seen in fig. 4).

Dictyotidium dictyotum Eisenack, 1938

4 DG00LK1.100npg1-N36, Lower Visby Beds, x 750.

5 DG00LK1.199npg1-P38, Lower Visby Beds, $x 750$.

9 DG00LK1.258ckd1-H48, Upper Visby Beds, $x 750$.

10 DG00LK1.56npg1-L35, 3, Lower Visby Beds, x 750.

Dictyotidium perlucidum Le Hérissé, 1989

6 DG00LK1.211npg1-E38, Upper Visby Beds, x 750.

Dictyotidium faviforme Schulz, 1967

2 DG00LK1.257-J10, (SEM), Upper Visby Beds, x 750. Specimen showing lateral split.

7 DG00LH2.49npg1-P45, 1, Upper Visby Beds, x 750. Specimen photographed under differential interference contrast.

8 DG00LH2.33npg1-M39, 4, Upper Visby Beds, x 750. Specimen photographed under differential interference contrast.

Dictyotidium stenodictyum Eisenack, 1965

3 DG00LK1.120-P12, (SEM), Lower Visby Beds, x 750. Specimen showing lateral split.

Quadraticum fantasticum Cramer, 1964b

11 DG00LK1.235npg3-S37, 3, Upper Visby Beds, $x 750$.

12 DG00LK1.251npg1-N45, 2, Upper Visby Beds, $x 750$.

Ammonidium microcladum (Downie, 1963) Lister, 1970

13 DG00LK1.258ckd1-J29, Upper Visby Beds, x 750.

14 DG00LK1.112-D5, (SEM) Upper Visby Beds, $x 750$.

Tasmanites sp.

15 DG00LK1.39npg1-P38, Lower Visby Beds, x 750. 
PLATE 4
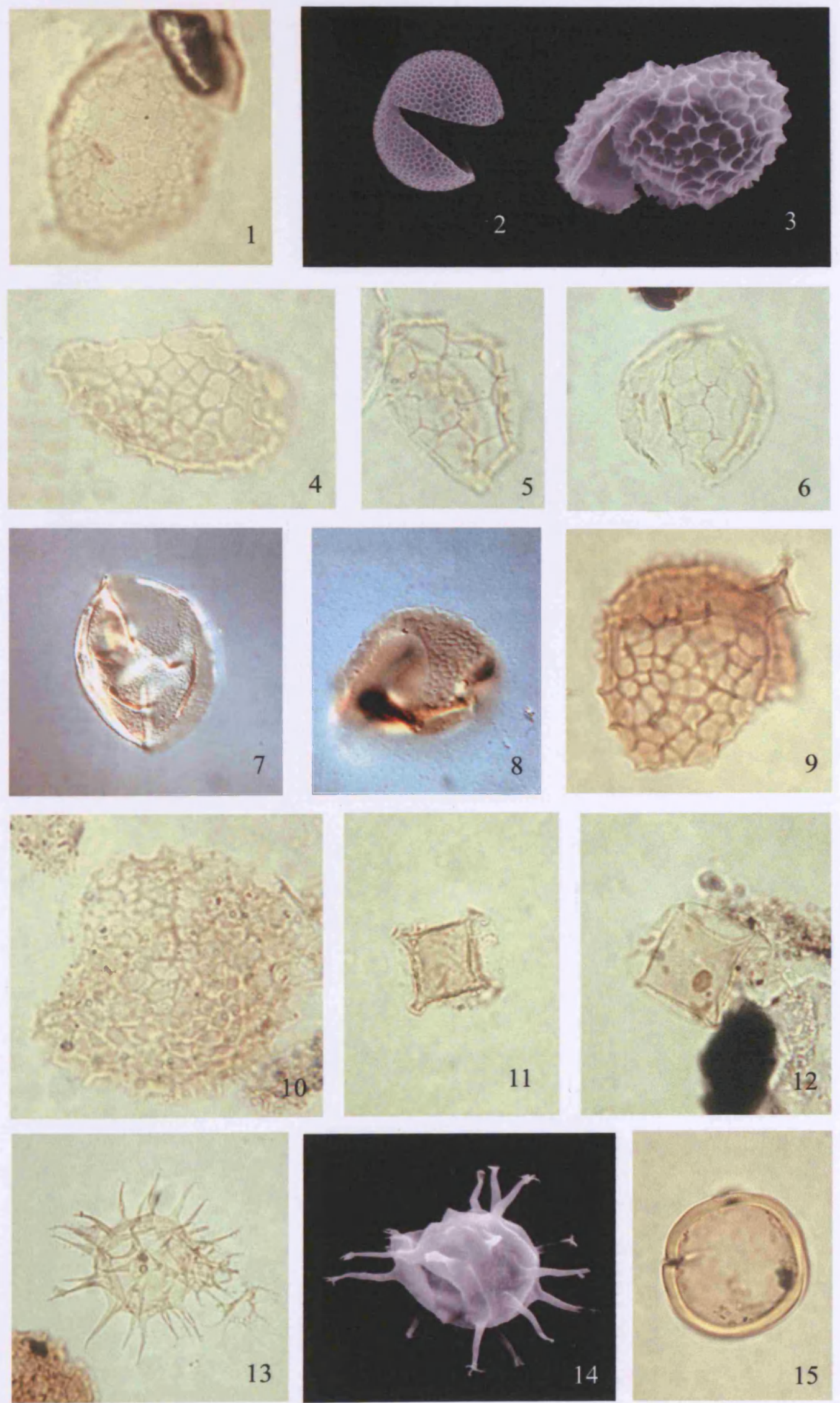
Fig.

1 DG00LK1.171ckd1-J39, 2, Upper Visby Beds, x 750. Specimen showing characteristic granulate vesicle.

2 DG00LK1.72npg1-M36, Lower Visby Beds, $x 750$.

3 DG00LK1.215npg1-J34, 3, Upper Visby Beds, $x 750$.

Pterospermella martinii Cramer, 1966a

4 DG00LK1.120-G5, (SEM), Lower Visby Beds, x 750. Specimen showing characteristic smooth vesicle.

5 DG00LK1.100-I14, (SEM), Lower Visby Beds, x 750.

6 DG00LH2.9ckd1-L33, Upper Visby Beds, $x 750$.

Pterospermella marysae Le Hérissé, 1989

7 DG00LH2.9ckd1-M49, 1, Upper Visby Beds, $x$ 750. Specimen showing characteristic narrow flange (less than half the width of the vesicle).

8 DG00LK.171ckd1-G41, 3, Upper Visby Beds, $x 750$.

Deunffia brevifurcata Hill, 1974

9 DG00LK.227npg1-G1, 1, Upper Visby Beds, 750.

Diexallophasis remota (Deunff, 1955) emend. Playford, 1977

10 DG00LK1.96npg1-M37, 3, Lower Visby Beds, x 750.

11 DG00LK1.171ckd1-L35, 4, Lower Visby Beds, $x 750$.

Deunffia monospinosa Downie, 1960

12 DG00LK.8npg1-H40, 3, Lower Visby Beds, x 750. 
PLATE 5
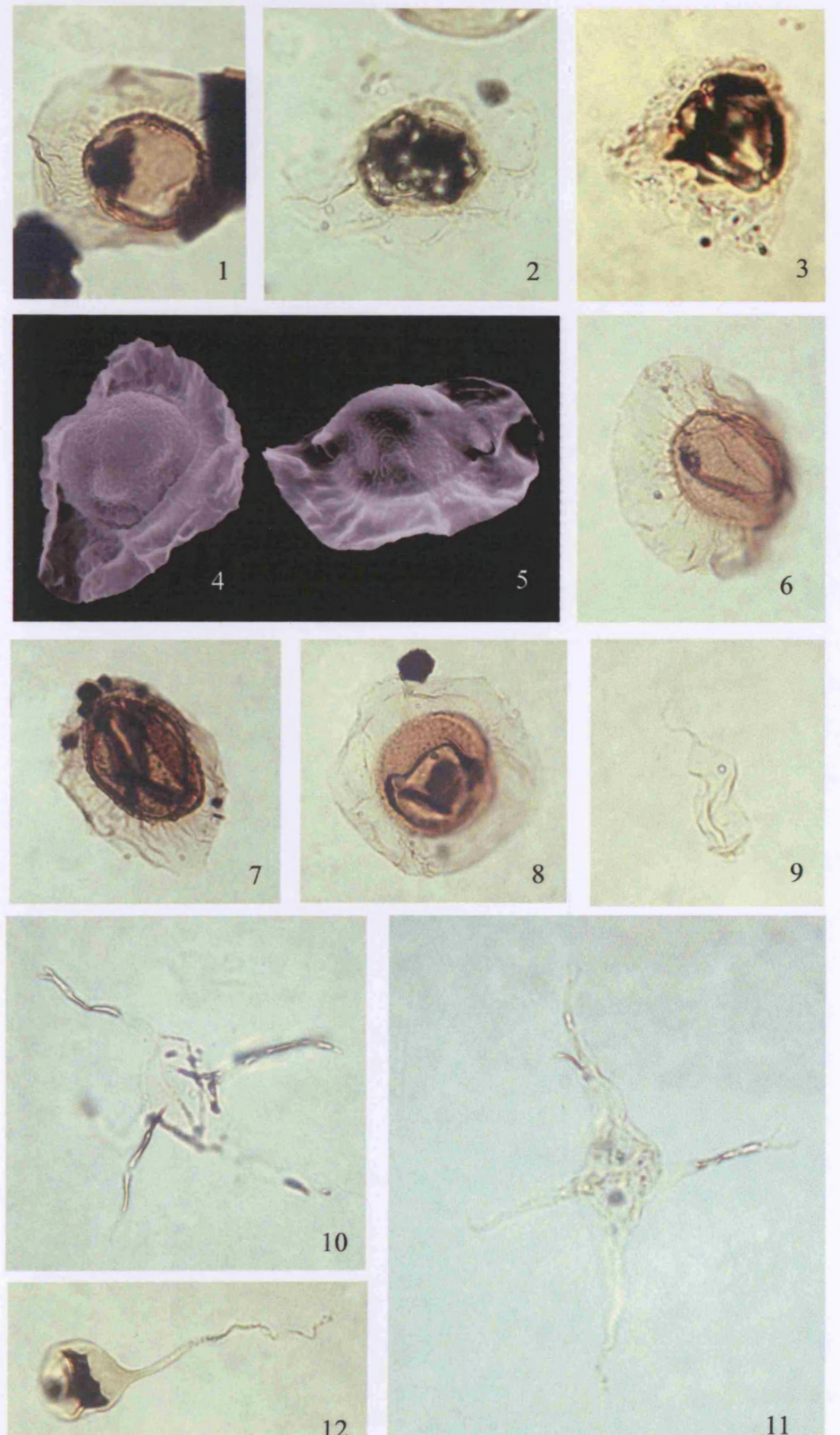


\section{EXPLANATION OF PLATE 6}

Fig.

Deunffia ramusculosa Downie, 1960

1 DG00LK1.28npg1-N31, 4, Lower Visby Beds, x 750.

2 DG00LK1.28npg1-H34, 4, Lower Visby Beds, x 750.

Diexallophasis gotlandica Cramer, 1970

3 DG00LK1.258ckd1-L30, 2, Upper Visby Beds, x 750.

4 DG00LH2.9ckd1-S32, 2, Upper Visby Beds, x 750.

Diexallophasis denticulata wolynica Kriyanov, 1978

5 DG00LH2.41npg1-V39, Upper Visby Beds, x 750.

Diexallophasis granulatispinosa (Downie, 1963) Hill, 1974

6 DG00LK1.223npg1-K43, 1, Upper Visby Beds, x 750.

7 DG00LK1.255npg1-G5, (SEM), Upper Visby Beds, $x 750$.

Dilatisphaera laevigata Lister, 1970

8 DG00LH2.9ckd1-K31, 1, Upper Visby Beds, x 750.

9 DG00LK1.255npg1-I12, (SEM), Upper Visby Beds, x 750.

10 DG00LH2.33ckd1-F40, 4, Upper Visby Beds, x 750. 
PLATE 6
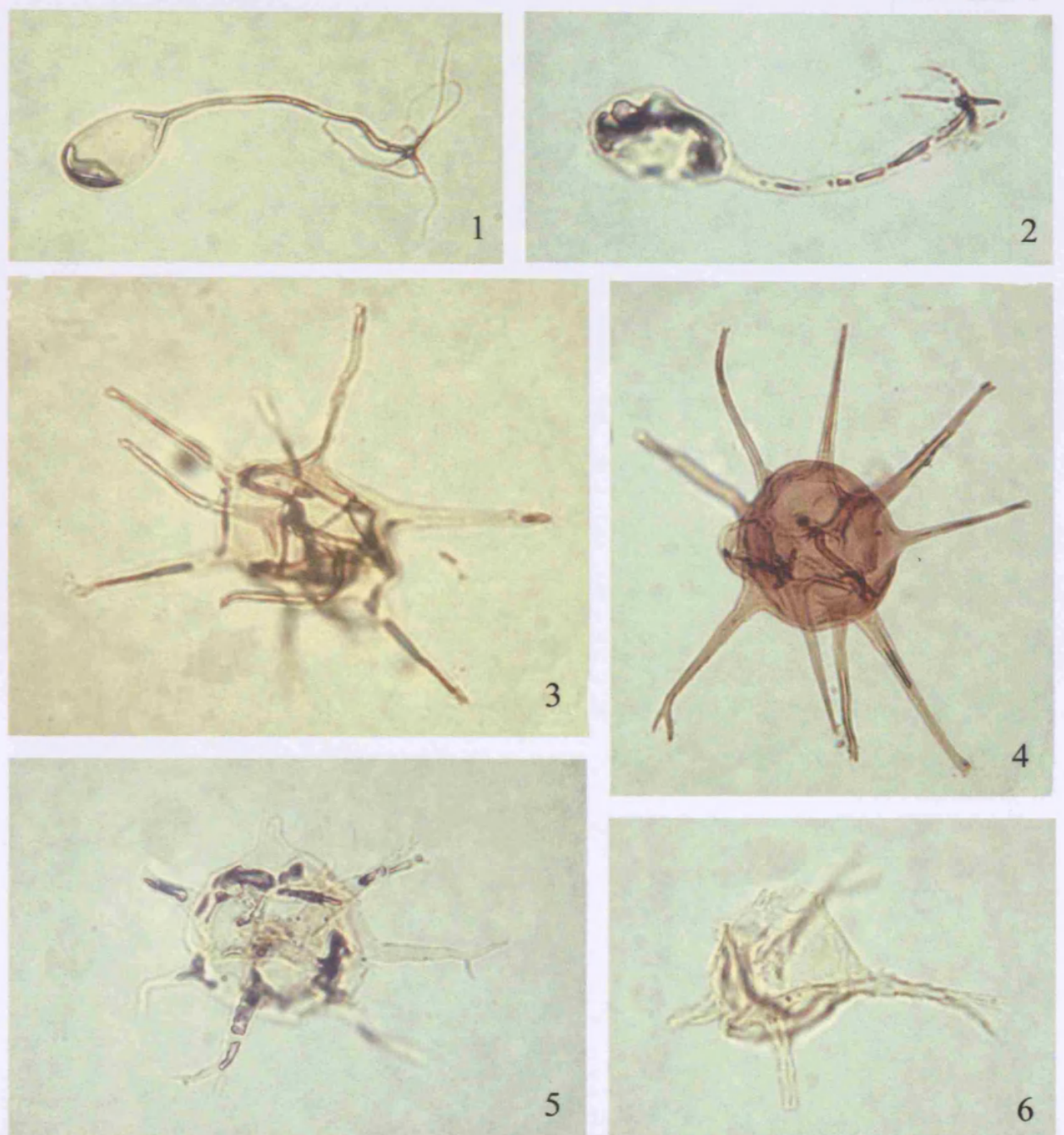

5
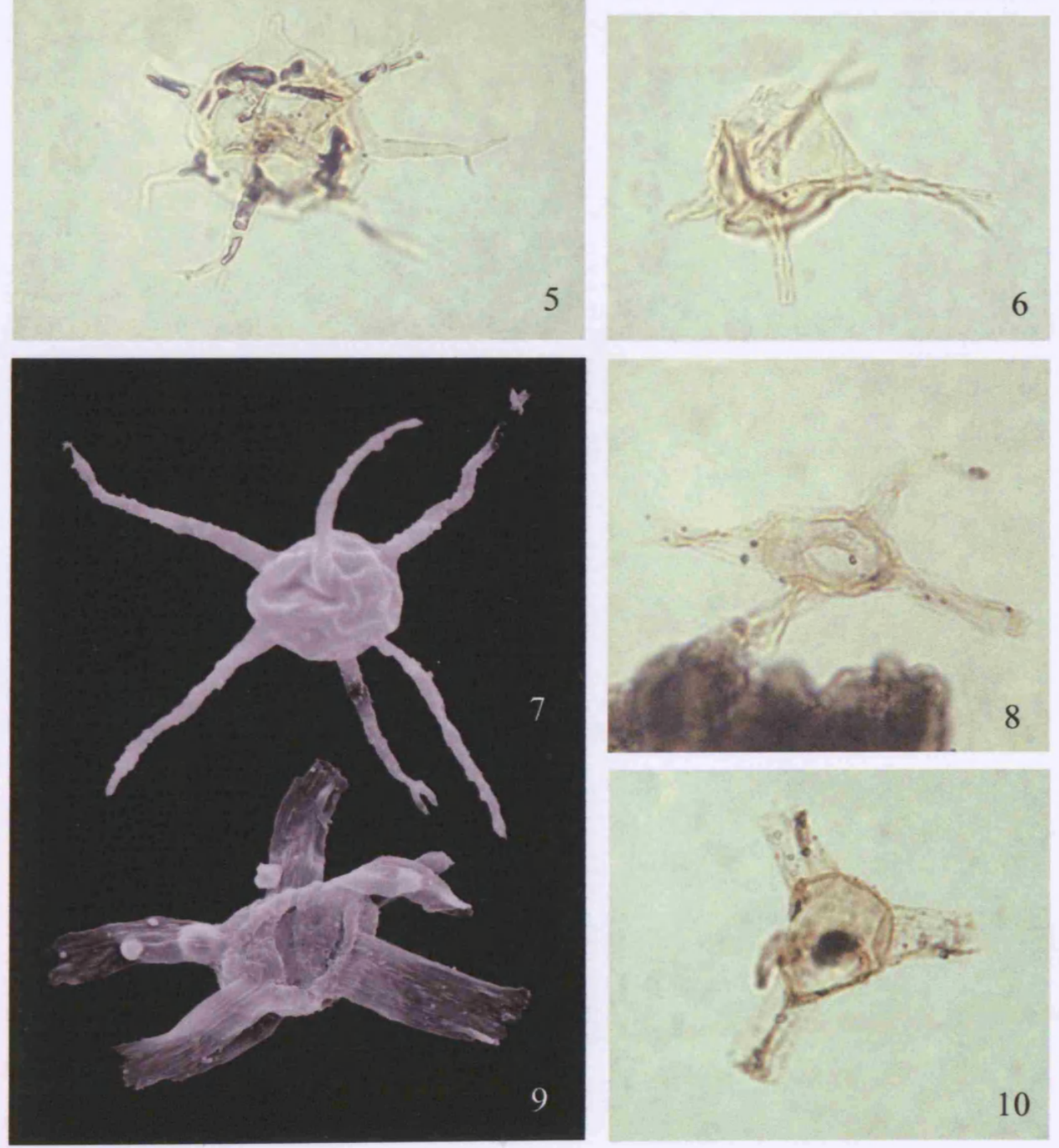


\section{EXPLANATION OF PLATE 7}

Fig.

Dilatisphaera williereae (Martin, 1966) Lister, 1970

1 DG00LK1.24ckd1-K35, 1, Lower Visby Beds, x 750. Specimen photographed under differential interference contrast.

2 DG00LH2.49npg1-V47, 1, Lower Visby Beds, x 750. Specimen photographed under differential interference contrast.

Domasia amphora (Martin, 1969) emend. Hill, 1974

3 DG00LK1.219npg1-H43, Upper Visby Beds, x 750.

Domasia bispinosa Downie, 1960

4 DG00LK1.40npg1-L39, 1, Lower Visby Beds, x 750.

Domasia quadrispinosa Hill, 1974

5 DG00LK1.28npg1-Q42, 2, Lower Visby Beds, x 750.

6 DG00LK1.195npg1-P45, Upper Visby Beds, x 750.

Domasia trispinosa (Downie, 1960) emend. Hill, 1974

7 DG00LH2.33ckd1-L33, Upper Visby Beds, x 750.

8 DG00LH2.33ckd1-D39, 1, Upper Visby Beds, x 750.

Eisenackidium ranaemanum Le Hérissé, 1989

9 DG00LK1.239npg1-G34, Upper Visby Beds, x 750.

Moyeria uticaensis Thusu, 1973

10 DG00LK1.239npg1-P36, 1, Upper Visby Beds, x 750.

Elektoriskos aurora Loeblich, 1970a

11 DG00LH2.17npg1-O33, Upper Visby Beds, $x 750$.

12 DG00LH2.41npg1-Q40, Upper Visby Beds, x 750. Specimen photographed under differential interference contrast.

Eupoikilofusa filifera (Downie, 1959) Dorning, 1981 emend

13 DG00LK1.211npg1-N38, Upper Visby Beds, x 750. 
PLATE 7
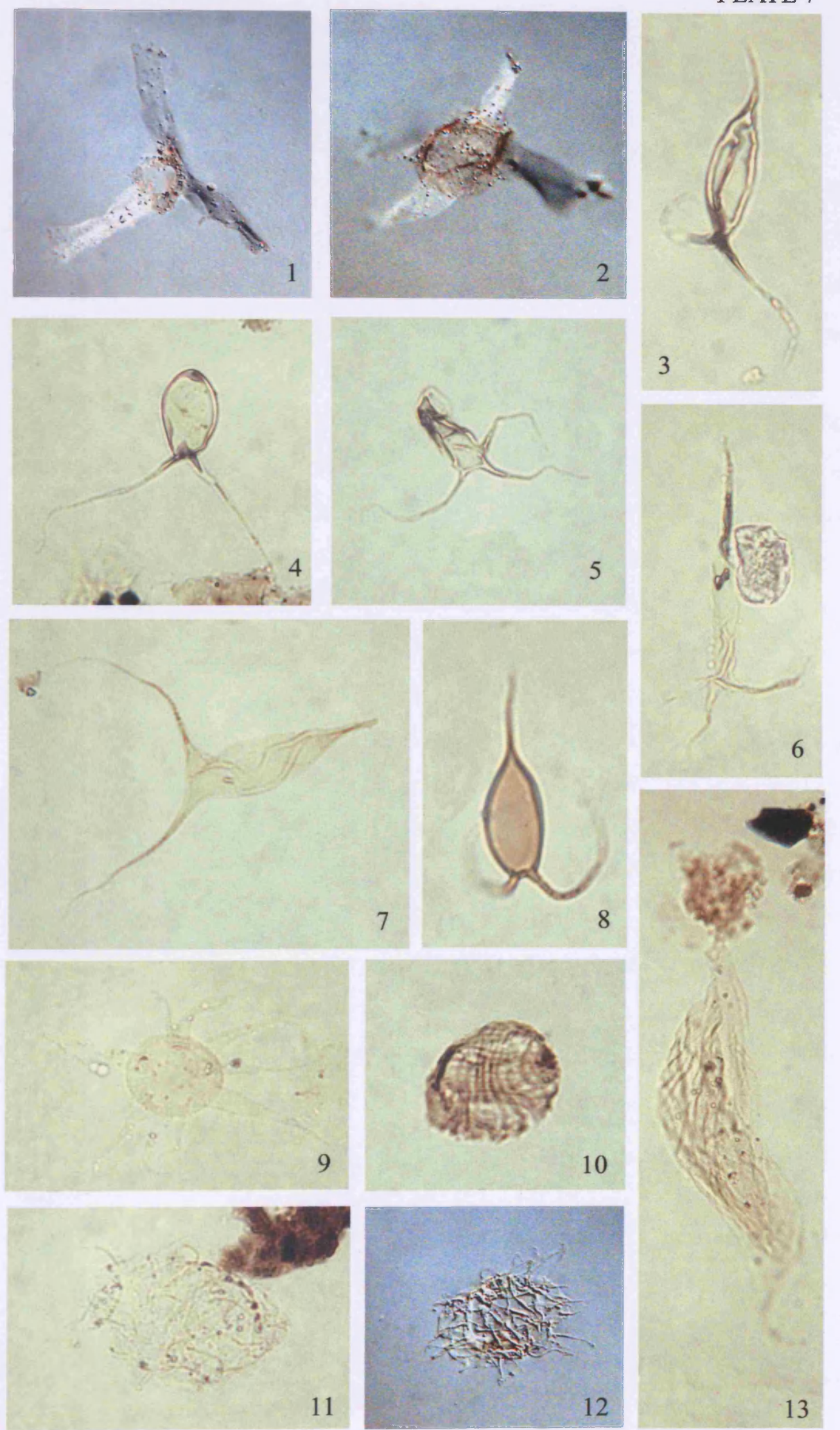
EXPLANATION OF PLATE 8

Fig.

Gorgonisphaeridium succinum Lister, 1970

1 DG00LH2.9ckd1-Y48, Upper Visby Beds, x 750.

2 DG00LH2.45npg2-U38, Upper Visby Beds, x 750. Specimen photographed under differential interference contrast.

Gracilisphaeridium encantador (Cramer, 1970) ex Eisenack et al., 1973

3 DG00LH2.33ckd1-G39, Upper Visby Beds, x 750.

4 DG00LH2.49npg1-H45, 2, Upper Visby Beds, x 750. Specimen photographed under differential interference contrast.

5 DG00LK1.255-J3, (SEM), Upper Visby Beds, x 750.

Helosphaeridium clavispinulosum Lister, 1970

6 DG00LK1.6npg1-N38, 4, Lower Visby Beds, 750.

7 DG00LK1.112-Q9, (SEM), Lower Visby Beds, x 750.

Helosphaeridium citrinipeltatum (Cramer \& Diez, 1972) Dorning,

1981

8 DG00LK1.258ckd1-O35, Upper Visby Beds, $x$ 750. Specimen photographed under differential interference contrast.

9 DG00LK1.255-O10, (SEM), Upper Visby Beds, x 750.

Helosphaeridium pseudodictyum Lister, 1970

10 DG00LK1.132npg1-K38, Lower Visby Beds, x 750. Specimen photographed under differential interference contrast.

11 DG00LK1.183npg1-T34, Upper Visby Beds, x 750. Specimen photographed under differential interference contrast.

Eupiokilofusa striatifera Cramer, 1964a

12 DG00LH2.33ckd1-G30, 4, Upper Visby Beds, x 750.

13 DG00LK1.112-N9, (SEM), Lower Visby Beds, x 750. 
PLATE 8
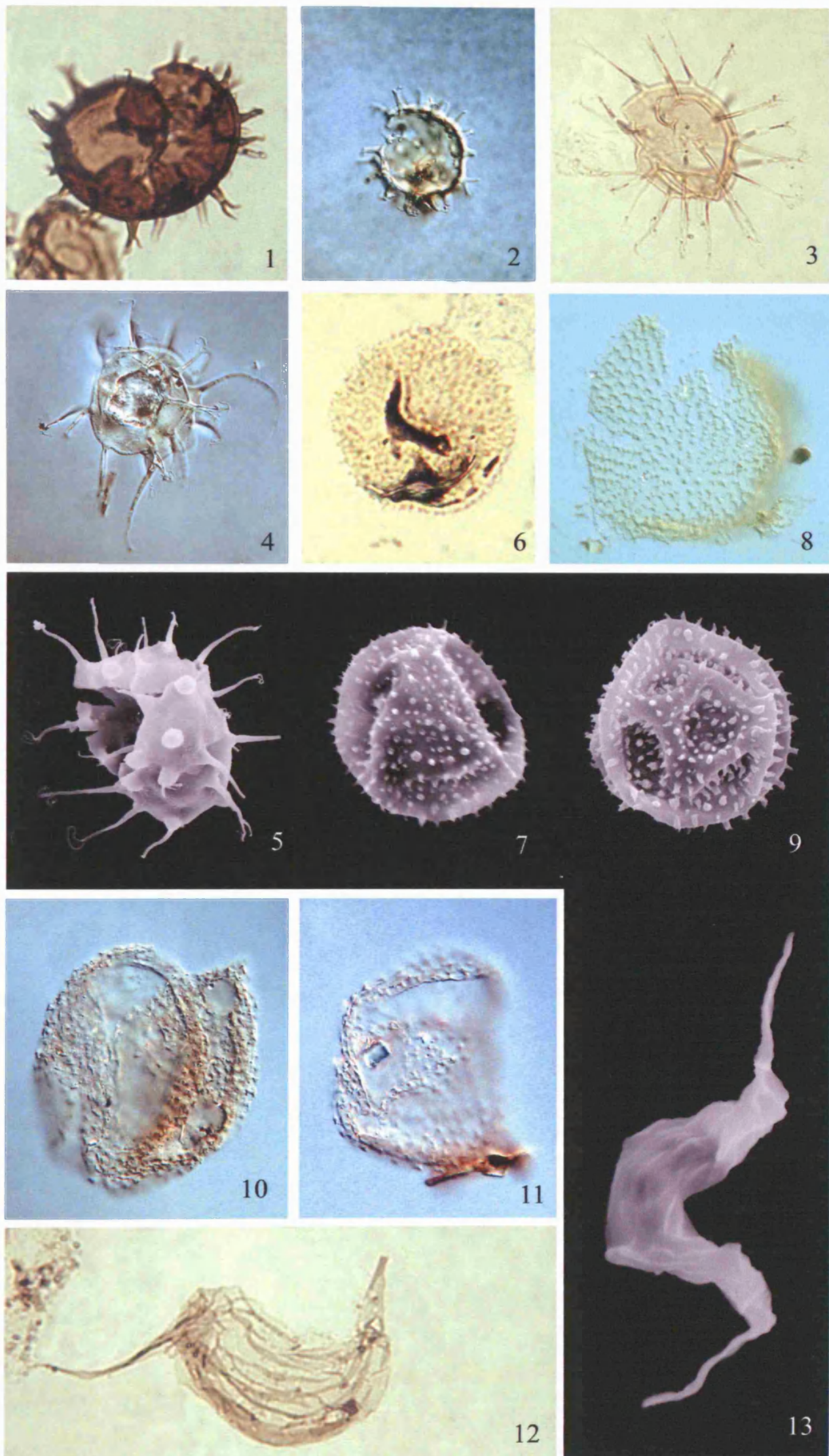

11

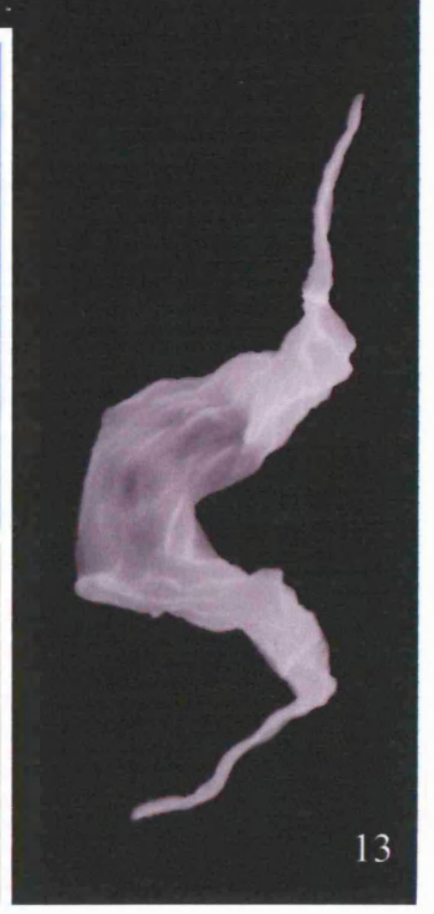


Fig.

1 DG00LH2.33npg1-X38, 2, Upper Visby Beds, x 500.

Hoegklintia digitata (Eisenack, 1938) Dorning, 1981

2 DG00LH2.33npg1-N40, 3, Upper Visby Beds, x 500.

3 DG00LK1.187npg1-K45, 4, Upper Visby Beds, x 500.

Hoegklintia visbyensis (Eisenack, 1959) Dorning, 1981

4 DG00LH2.41npg1-L41, 3, Upper Visby Beds, x 500.

Leiofusa parvitatis Loeblich, 1970

5 DG00LK1.227npg1-M34, Upper Visby Beds, x 750.

6 DG00LK1.96npg1-G37, Lower Visby Beds, x 750.

Leiofusa cf. banderillae Cramer, 1964b

7 DG00LK1.247npg1-P38, Upper Visby Beds, $x 750$.

8 DG00LK1.219npg1-T45, Upper Visby Beds, $x 750$. 
PLATE 9
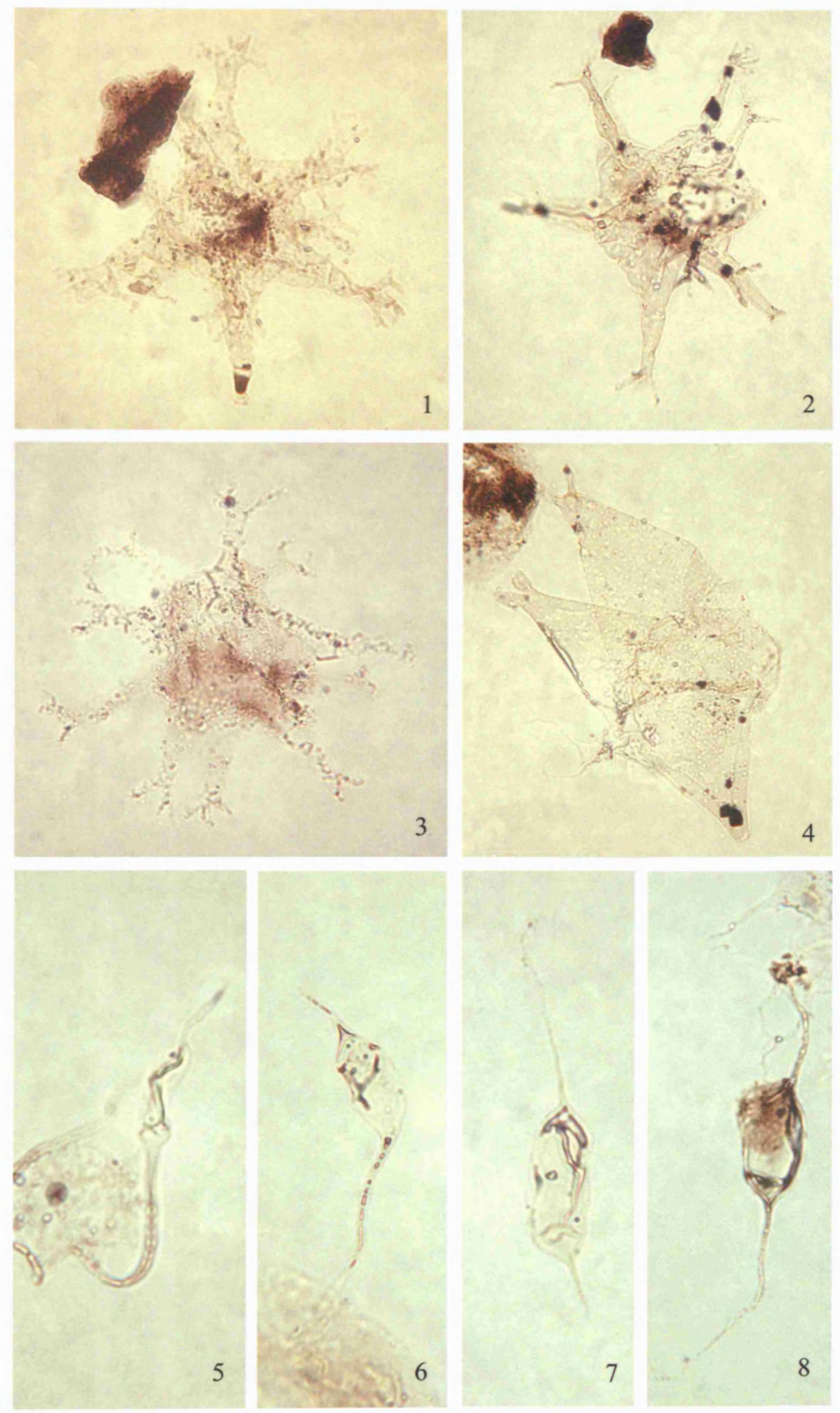
Fig.

Leiosphaeridia (Eisenack, 1958b) emend. Downie \& Sarjeant, 1963, emend. Turner, 1984

1 DG00LK1.80ckd1-M33, 4, Lower Visby Beds, x 750. Large thin walled specimen.

2 DG00LK1.80ckd1-F29, 3, Lower Visby Beds, x 750. Small thin walled specimen.

3 DG00LK1.80ckd1-R30, 2, Lower Visby Beds, $x$ 750. Small thick walled specimen.

4 DG00LK1.258ckd1-N45, 4, Upper Visby Beds, $x$ 750. Large thick walled specimen.

Leprotolypa gordonense Cramer, 1963

$5 \quad$ DG00LK1.171npg1-N49, 4, Upper Visby Beds, x 750.

Micrhystridium eatonense Downie, 1959

6 DG00LK1.187npg1-L35, 4, Upper Visby Beds, x 750.

7 DG00LH2.5npg1-H38, Upper Visby Beds, $x 750$.

Micrhystridium irevikensis Le Hérissé, 1989

8 DG00LK1.80ckd1-O40, Lower Visby Beds, $x$ 750. Specimen showing some coarse granulation to micro barbs on the distal parts of the processes.

9 DG00LK1.258ckd1-J29, Upper Visby Beds, x 750.

Micrhystridium stellatum Deflandre, 1945

10 DG00LK1.144ckd1-Q46, 1, Upper Visby Beds, x 750.

Multiplicisphaeridium arbusculum Dorning, 1981

11 DG00LK1.187npg1-O42, Upper Visby Beds, x 750. Specimen photographed under differential interference contrast.

12 DG00LK1.28npg1-K30, 4, Lower Visby Beds, $x$ 750. Specimen photographed under differential interference contrast.

Multiplicisphaeridium cladum (Downie, 1963) Eisenack, 1969

13 DG00LK1.219npg1-G51, Upper Visby Beds, $x$ 750.

14 DG00LK1.215npg1-H43, 3, Upper Visby Beds, $x$ 750. Broken specimen, but distal palmate branching can be seen.

Multiplicisphaeridium forquiferum (Cramer \& Díez, 1972b) Eisenack et

$$
\text { al., } 1973
$$

15 DG00LK1.144ckd1-K33, 1, Upper Visby Beds, x 750.

16 DG00LH2.9ckd1-M49, 1, Upper Visby Beds, $x 750$. 
PLATE 10
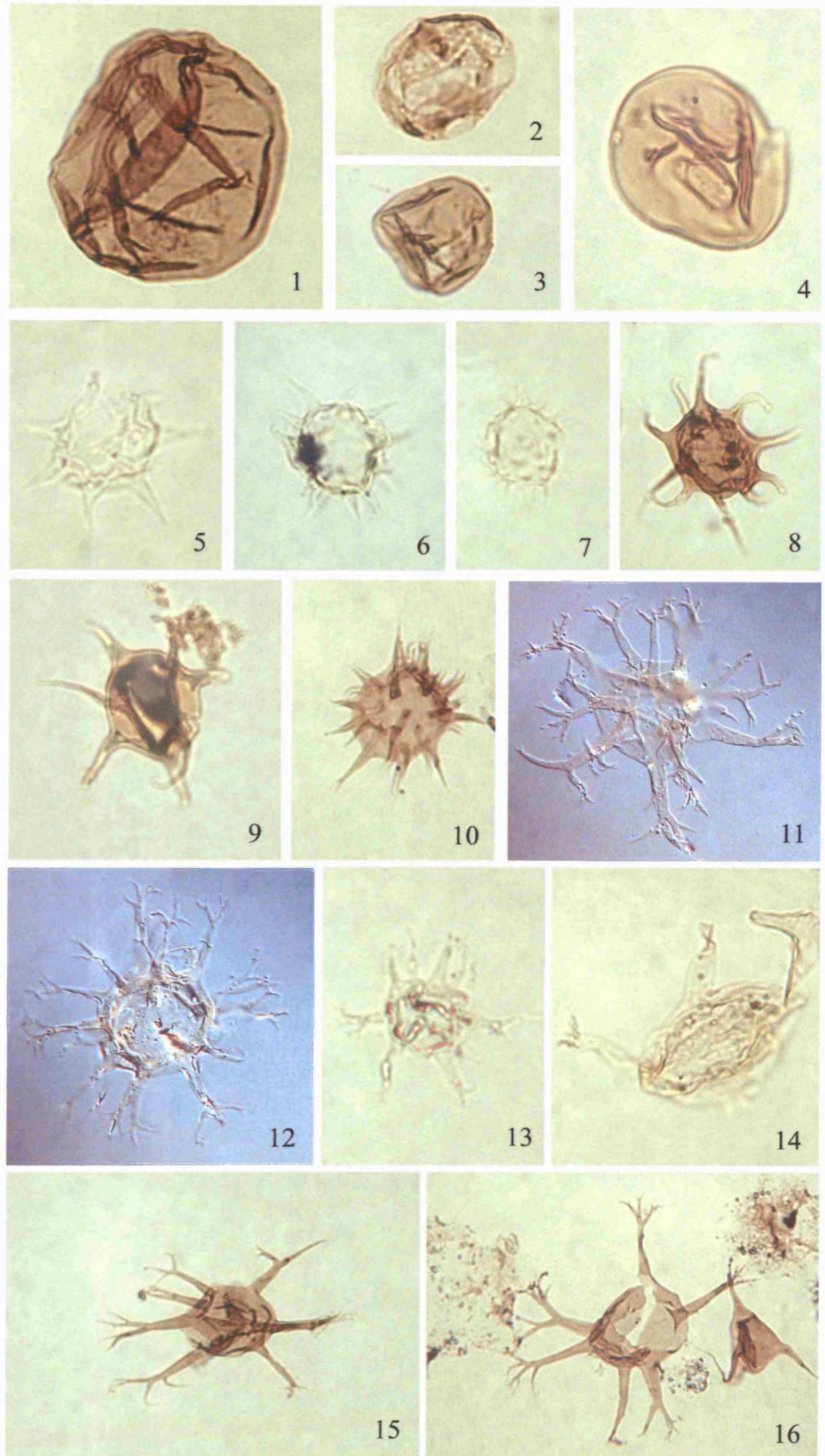
Fig.

Multiplicisphaeridium fisheri (Cramer, 1968) Lister, 1970

1 DG00LK1.223npg1-O40, Upper Visby Beds, x 750. Specimen showing lateral split.

Multiplicisphaeridium minguisi Le Hérissé, 1989

2 DG00LK1.144ckd1-P36, Upper Visby Beds, x 750.

3 DG00LH2.33ckd1-P45, 3, Upper Visby Beds, x 750.

Multiplicisphaeridium forquillùm (Cramer \& Díez, 1972b)

Eisenack et al., 1973

4 DG00LH2.9ckd1-M48, 1, Upper Visby Beds, x 750.

5 DG00LH2.9ckd1-R50, 3, Upper Visby Beds, x 750.

Multiplicisphaeridium monki Le Hérissé, 1989

6 DG00LK1.144ckd1-L36, Upper Visby Beds, x 750.

Multiplicisphaeridium neaghae Cramer, 1970 ex Eisenack et al., 1973

7 DG00LK1.211npg1-F40, Upper Visby Beds, $x 750$.

Multiplicisphaeridium osgoodense (Cramer \& Díez 1972b)

Eisenack et al. 1973

8 DG00LK1.223npg1-M40, 2, Upper Visby Beds, x 750.

Multiplicisphaeridium rochesterense (Cramer and Díez, 1972b)

Eisenack et al., 1973

9 DG00LK1.219npg1-J36, Upper Visby Beds, x 750. 
PLATE 11

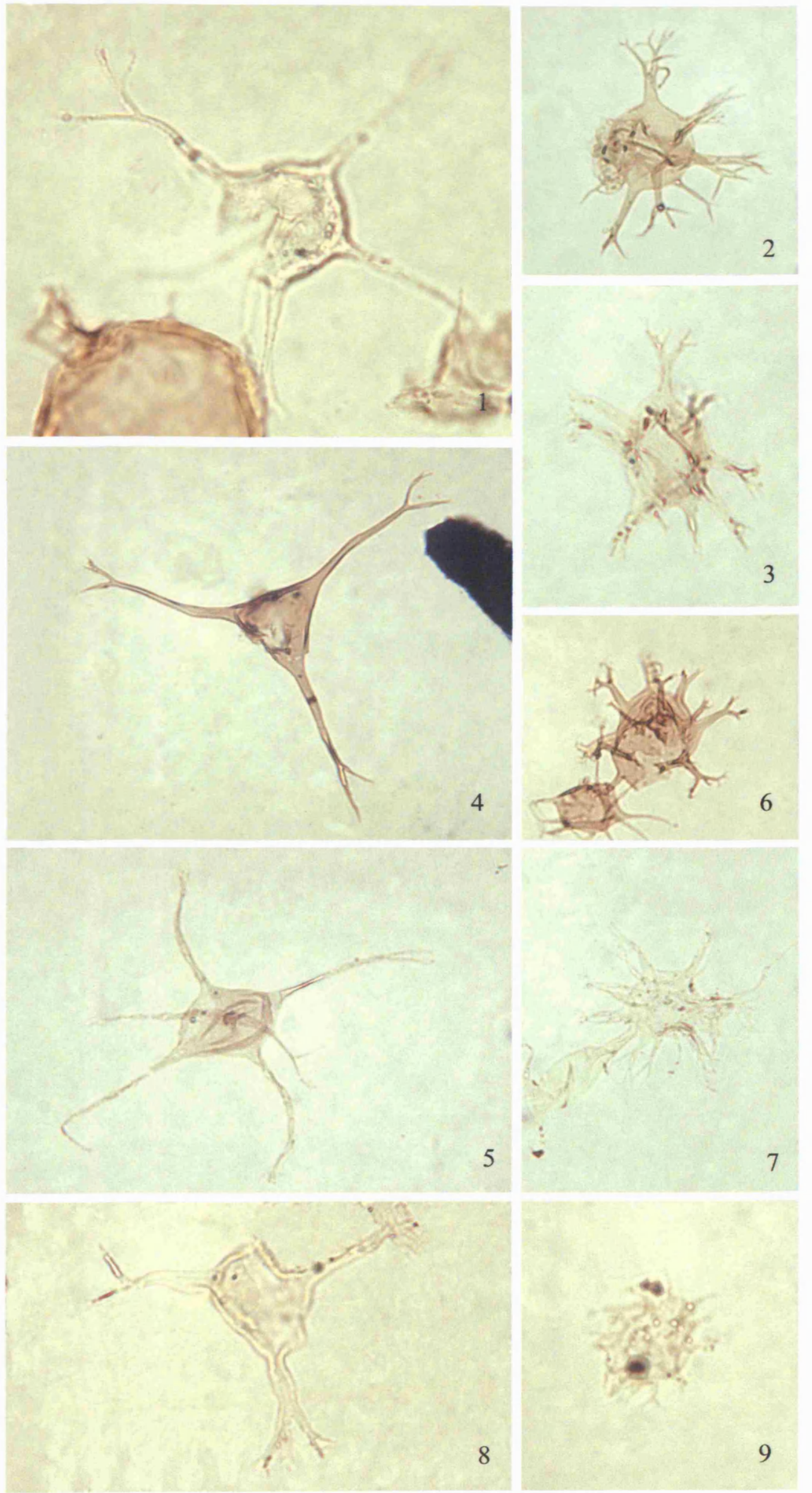


Fig.

Multiplicisphaeridium variabile (Lister, 1970) Dorning, 1981

1 DG00LH2.39npg1-L32, 3, Upper Visby Beds, x 750.

2 DG00LK1.80ckd1-Q39, 1, Lower Visby Beds, x 750.

Multiplicisphaeridium cf. variabile (Lister, 1970) Dorning, 1981

3 DG00LH2.39npg1-U42, Upper Visby Beds, x 750.

Onondagella asymmetrica (Deunff, 1954 ex Deunff, 1961) Cramer,

1966b, emend. Playford, 1977

4 DG00LK1.4npg1-F43, 3, Lower Visby Beds, x 750.

Oppilatala fermosa (Cramer, 1970) Le Hérissé, 1989

5 DG00LK1.80ckd1-G39, Lower Visby Beds, x 750.

6 DG00LK1.12npg1-L41, 4, Lower Visby Beds, x 750.

Oppilatala insolita compacta Le Hérissé, 1989

7 DG00LK1.56npg1-R36, 1, Lower Visby Beds, x 750.

8 DG00LK1.179npg1-E43, Upper Visby Beds, $x 750$. 
PLATE 12
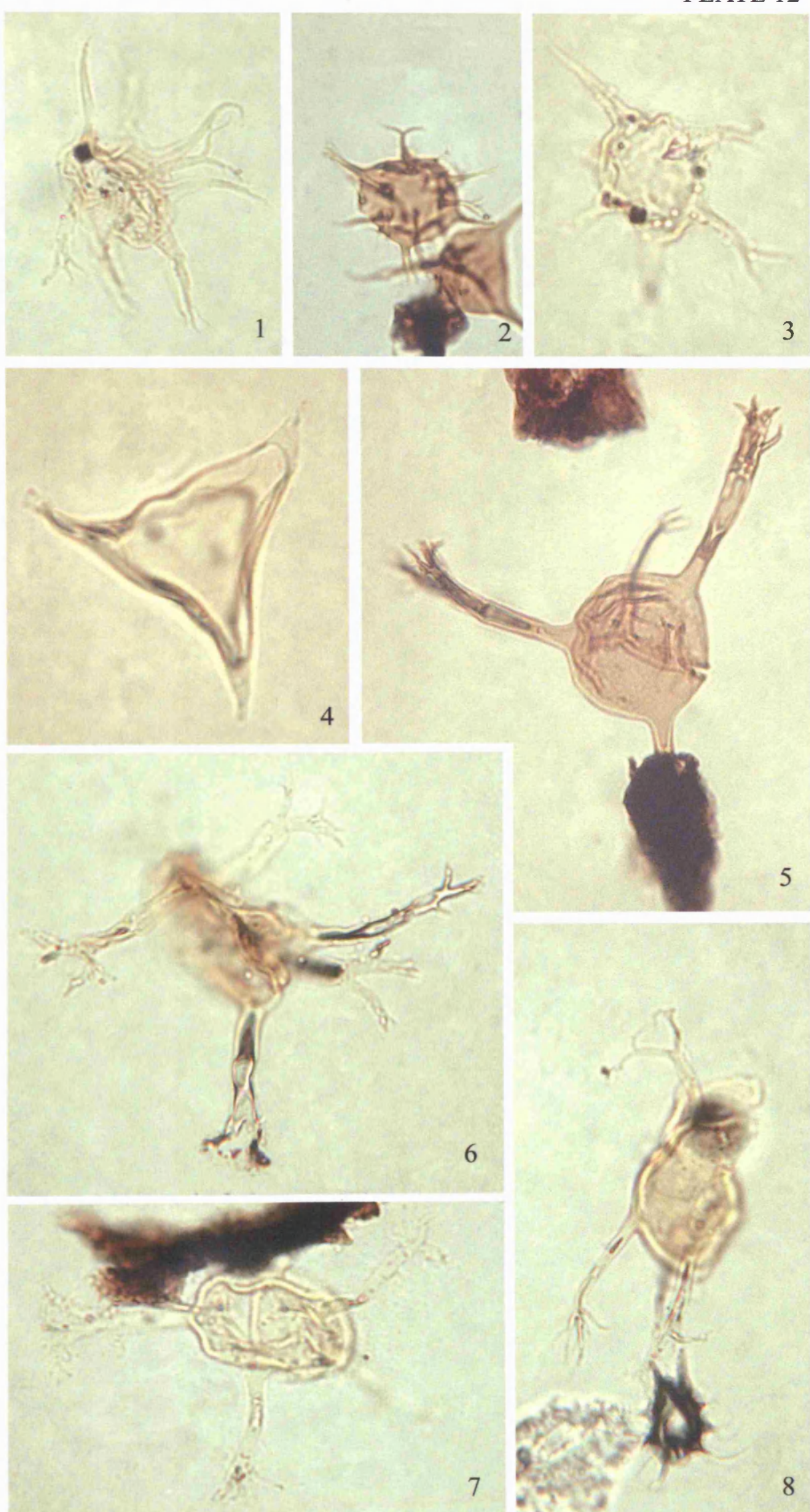

6

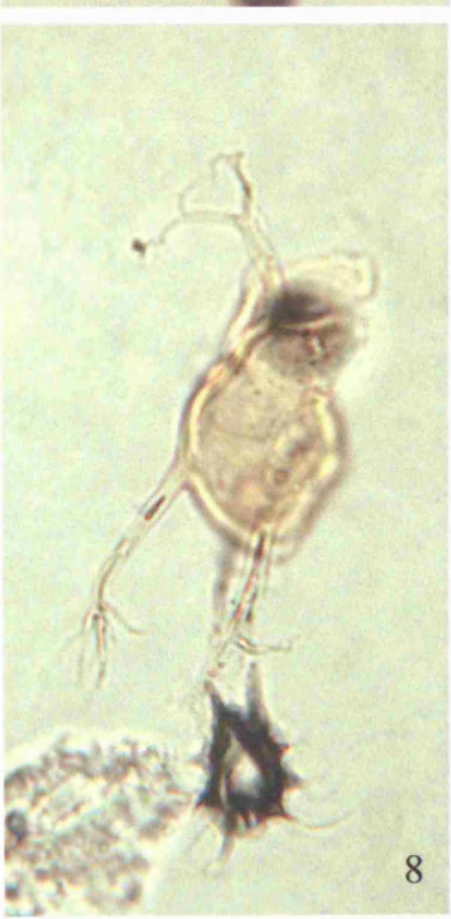


Fig.

1 DG00LK1.56npg1-N37, 3, Lower Visby Beds, x 750.

Oppilatala juvensis Le Hérissé, 1989

2 DG00LK1.108npg1-L36, Upper Visby Beds, x 750.

Oppilatala insolita insolita Cramer \& Díez, 1972

3 DG00LK1.52npg1-L31, Lower Visby Beds, x 750.

4 DG00LK1.12npg1-Q48, 3, Lower Visby Beds, x 750.

Oppilatala ramusculosa (Deflandre, 1945) Dorning, 1981

5 DG00LK1.144ckd1-S38, Upper Visby Beds, x 750.

6 DG00LK1.171ckd1-L39, Upper Visby Beds, x 750.

Oppilatala singularis Le Hérissé, 1989

7 DG00LK1.171ckd1-T41, 3, Upper Visby Beds, x 750. 
PLATE 13

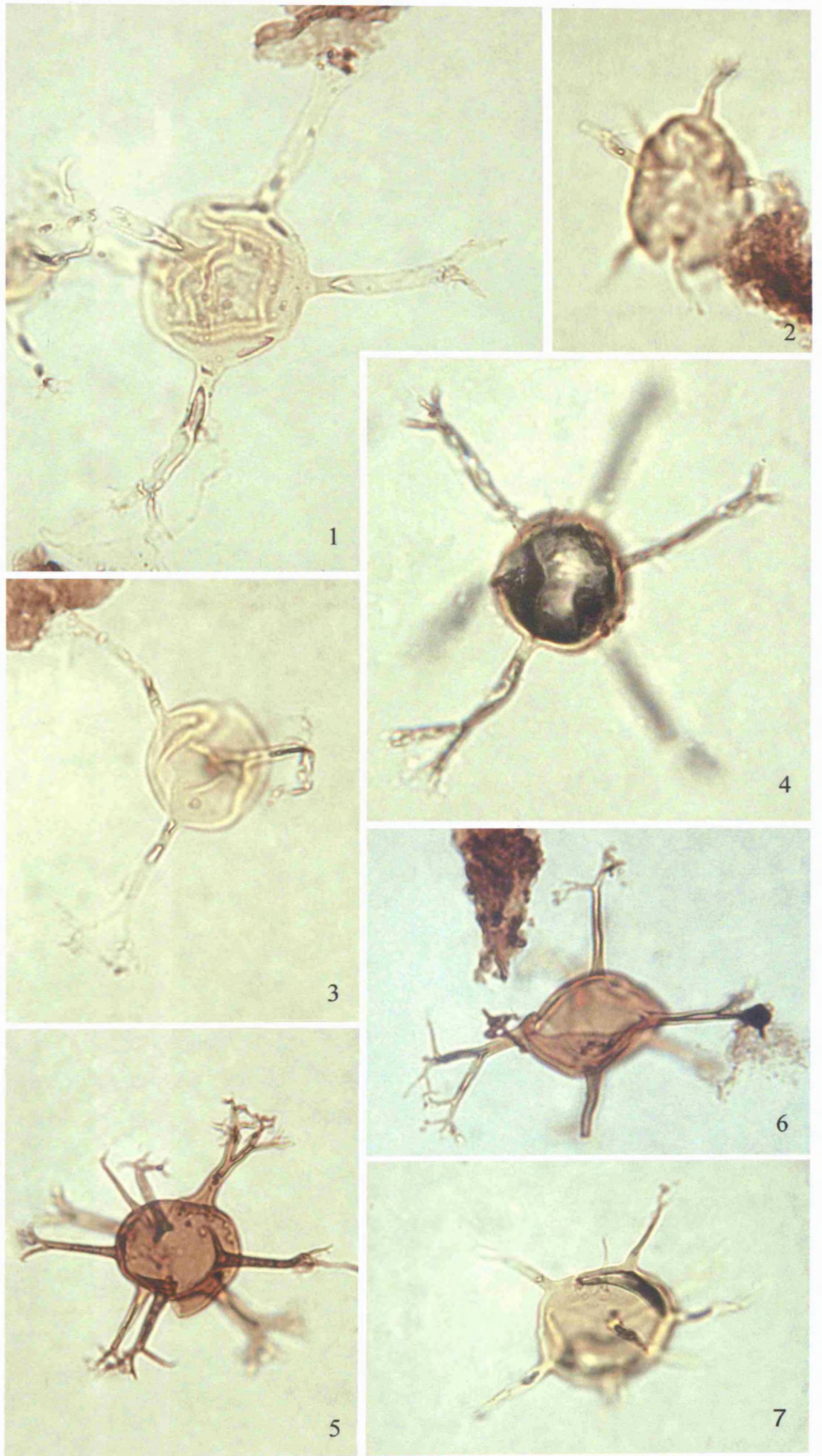


Fig.

1 DG00LK1.155npg1-E33, 2, Upper Visby Beds, x 750.

Pulvinosphaeridium pulvinellum Eisenack, 1954

2 DG00LK1.76npg1-S42, 3, Lower Visby Beds, x 500.

Salopidium fragelliforme Le Hérissé, 1989

3 DG00LK1.203npg1-T34, Upper Visby Beds, $x 750$.

Salopidium granuliferum (Downie, 1959) Dorning, 1981

4 DG00LK1.144ckd1-J45, 2, Upper Visby Beds, x 750.

5 DG00LK1.80ckd1-T31, Lower Visby Beds, $x 750$.

Salopidium wenlockense (Downie, 1959) Dorning, 1981

6 DG00LK1.84npg1-R45, 3, Lower Visby Beds, x 750.

7 DG00LK1.8npg1-O42, Lower Visby Beds, $x 750$.

Salopidium aff. granuliferum (Downie, 1959) Dorning, 1981

8 DG00LK1.257npg1-R35, 1, Upper Visby Beds, $x 750$.

9 DG00LK1.24npg1-G34, Lower Visby Beds, $x 750$.

Salopidium woolhopense Dorning, 1981

10 DG00LK1.80ckd1-F39, 4, Lower Visby Beds, x 750.

11 DG00LK1.80ckd1-J34, 4, Lower Visby Beds, $x 750$. 
PLATE 14
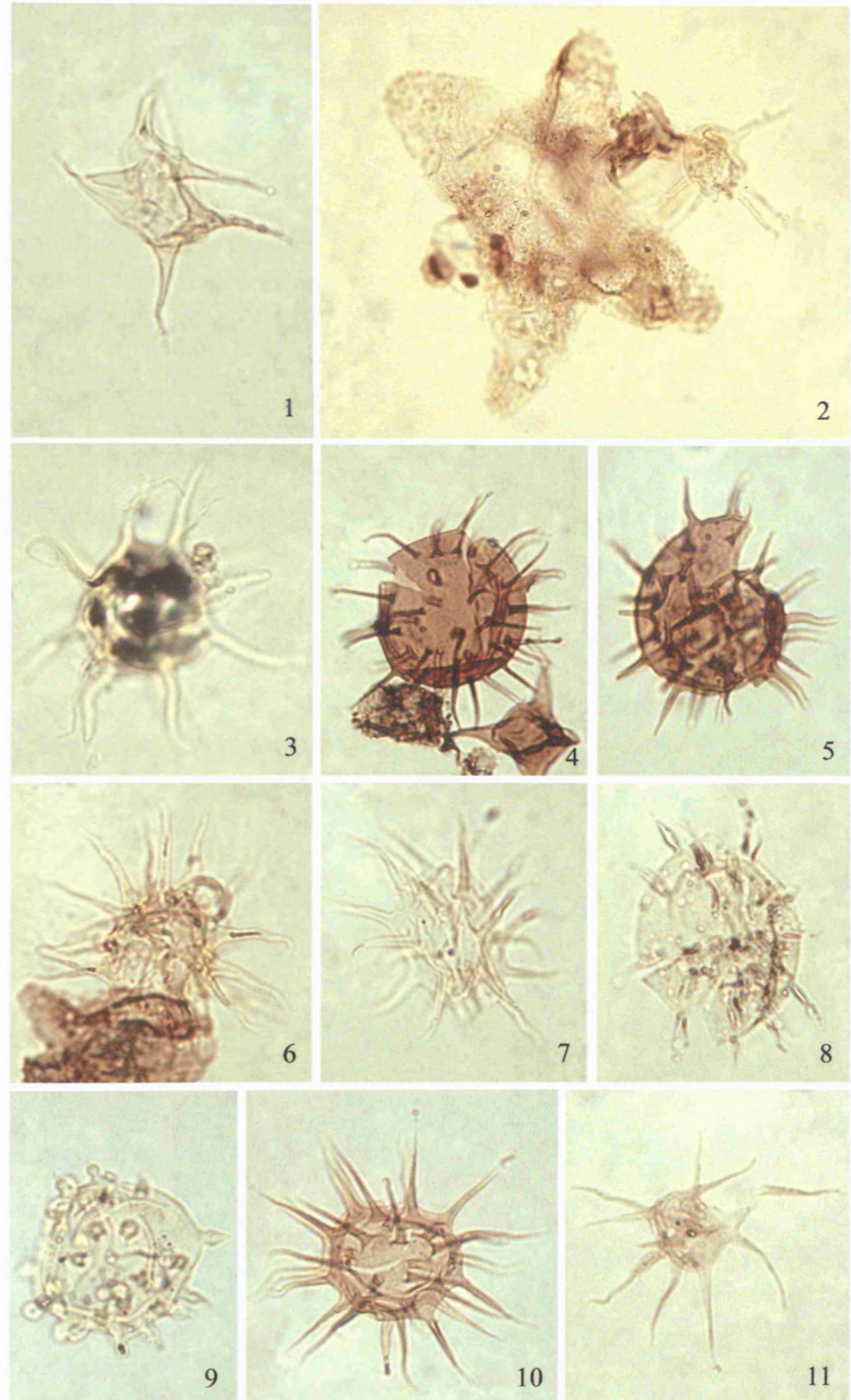
Fig.

1 DG00LH2.33ckd1-F41, 4, Upper Visby Beds, x750.

2 DG00LH2.9ckd1-K31, Upper Visby Beds, $x 750$.

Schismatosphaeridium longhopense Dorning, 1981

3 DG00LK1.44npg1-P35, Lower Visby Beds, $x 750$.

$4 \quad$ DG00LK1.68npg1-P35, Lower Visby Beds, $x 750$.

Schismatosphaeridium rugulosum Dorning, 1981 emend

5 DG00LK1.44npg1-S38, Upper Visby Beds, $x 750$.

6 DG00LH2.9npg1-L34, 3, Upper Visby Beds, $x 750$.

Schismatosphaeridium perforatum Staplin et al., 1965

7 DG00LK1.8npg1-O45, 3, Lower Visby Beds, $x 750$.

8 DG00LK1.8npg1-K38, 1, Lower Visby Beds, $x 750$.

Tunisphaeridium parvum Deunff \& Evitt, 1968

9 DG00LK1.147npg1-N34, Upper Visby Beds, $x 750$.

Tunisphaeridium tentaculaferum (Martin, 1967) Cramer, 1970

10 DG00LK1.88npg1-U38, Lower Visby Beds, x 750.

11 DG00LK1.128npg1-Q39, Lower Visby Beds, $x 750$.

Tylotopalla robustispinosa (Downie, 1959) Eisenack et al., 1973

12 DG00LK1.203npg1-N42, Upper Visby Beds, x 750.

Tylotopalla gaupa (Cramer, 1964b) Eisenack et al., 1973

13 DG00LK1.8npg1-G39, 4, Lower Visby Beds, x 750.

14 DG00LK1.12npg1-K45, 4, Lower Visby Beds, $x 750$. 
PLATE 15
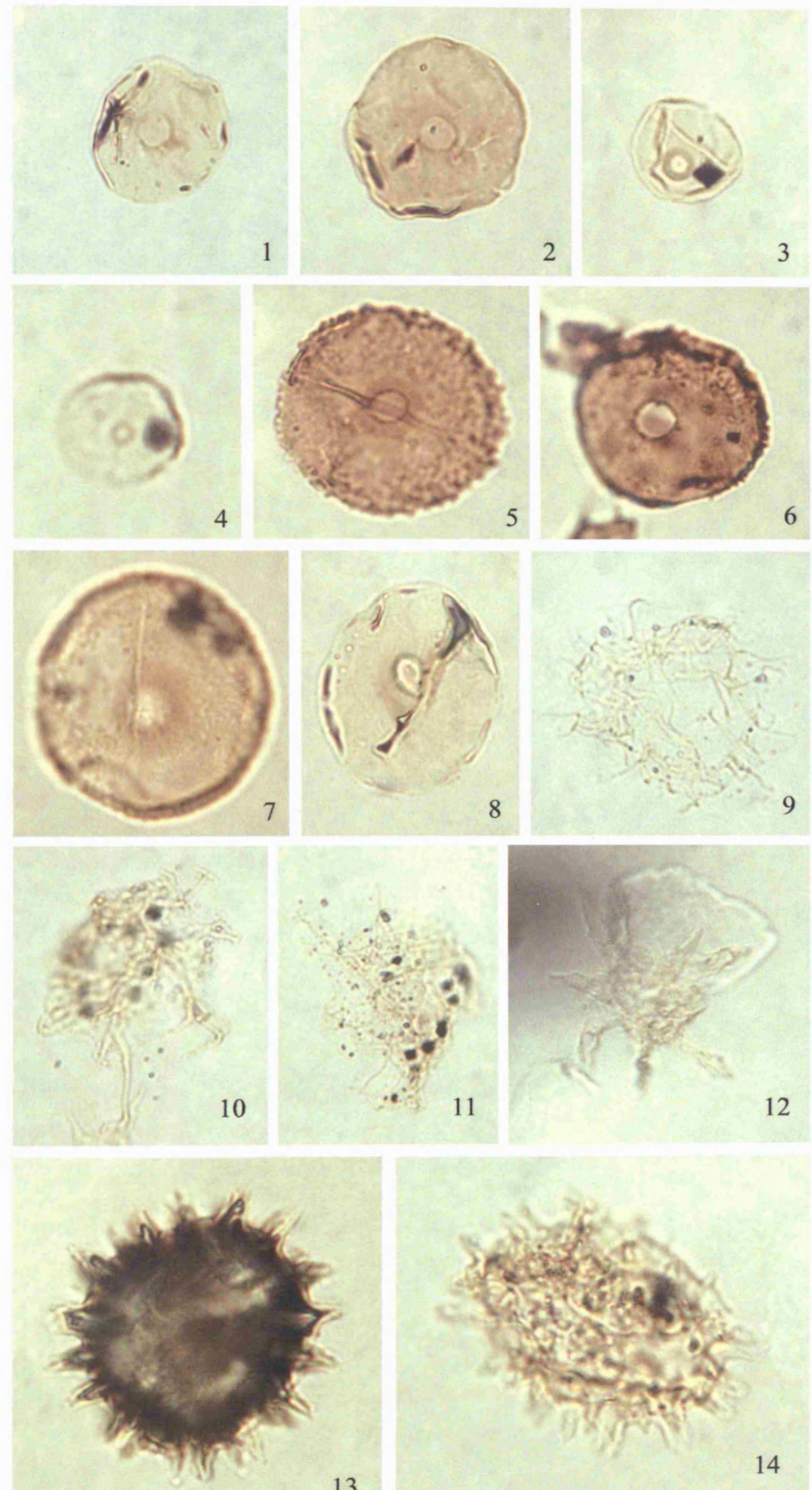
Fig.

Veryhachium checkleyense Dorning, 1981

1 DG00LK1.191npg1-D36, 1, Upper Visby Beds x 750.

Veryhachium pertonense Dorning, 1981

2 DG00LH2.33npg1-N37, 1, Upper Visby Beds x 750.

3 DG00LH2.9ckd1-L33, 1, Upper Visby Beds x 750.

Veryhachium rhomboidium (Downie, 1959) emend. Turner, 1984

4 DG00LK1.258npg1-T40, 4, Upper Visby Beds x 750.

Veryhachium trispinosum (Eisenack, 1938) Stockmans \& Willière,

1962

5 DG00LK1.32npg1-K40, 4, Lower Visby Beds, x 750.

6 DG00LK1.60npg1-H32, Lower Visby Beds, x 750.

Veryhachium wenlockium (Downie, 1959) Stockmans \& Willière,

1962

7 DG00LK1.258ckd1-J38, Upper Visby Beds x 750.

8 DG00LK1.258ckd1-H35, Upper Visby Beds x 750. 
PLATE 16
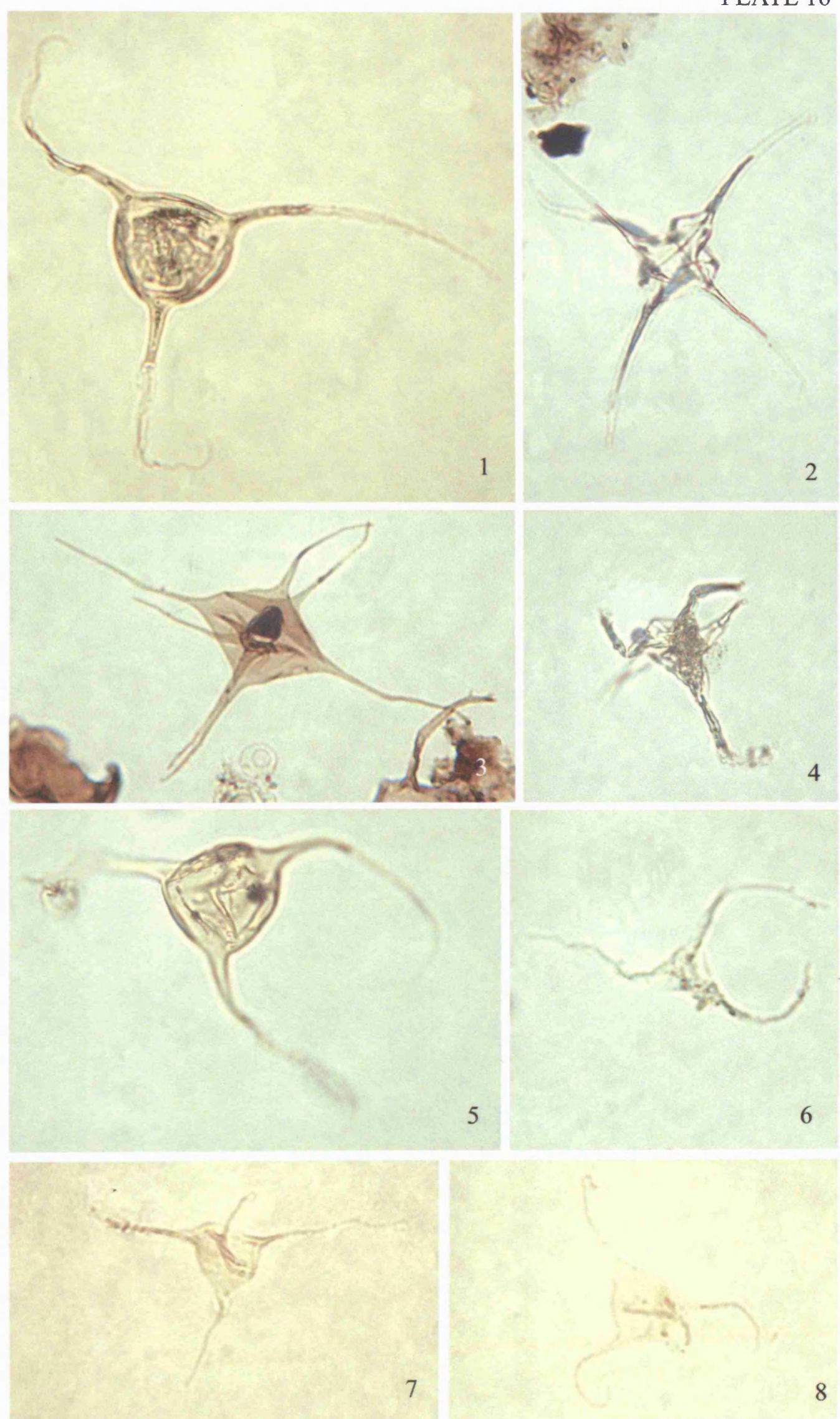
Fig.

Visbysphaera brevifurcata (Eisenack, 1954) Lister, 1970

1 DG00LK1.211-L15, (SEM), Upper Visby Beds, x 750.

2 DG00LK1.211-O12, (SEM), Upper Visby Beds, x 750.

Visbysphaera connexa connexa Le Hérissé, 1989

3 DG00LK1.112-M7, (SEM), Lower Visby Beds, x 750.

4 DG00LK1.80ckd1-J35, 1, Lower Visby Beds, x 750.

Visbysphaera connexa crispa Le Hérissé, 1989

5 DG00LK1.24npg1-L34, Lower Visby Beds, x 750.

6 DG00LK1.4npg1-M43, Lower Visby Beds, x 750.

Visbysphaera connexa hirsuta Le Hérissé, 1989

7 DG00LK1.36npg1-U41, 1, Lower Visby Beds, x 750.

8 DG00LK1.40npg1-L37, 1, Lower Visby Beds, $x 750$.

Visbysphaera gotlandica Eisenack, 1954

9 DG00LK1.203npg1-J39, 3, Upper Visby Beds, x 750.

Visbysphaera erratica brevis Le Hérissé, 1989

10 DG00LK1.12npg1-J46, Lower Visby Beds, x 750.

11 DG00LH2.33ckd1-P40, Upper Visby Beds, x 750.

Visbysphaera meson Eisenack 1955

12 DG00LK1.257npg1-L35, 3, Upper Visby Beds, $x 750$.

13 DG00LK1.234npg1-O34, Upper Visby Beds, $\mathrm{x} 750$.

Visbysphaera cf. gotlandica (Downie, 1959) Dorning, 1981

14 DG00LK1.40npg1-L47, 4, Lower Visby Beds, x 750. 

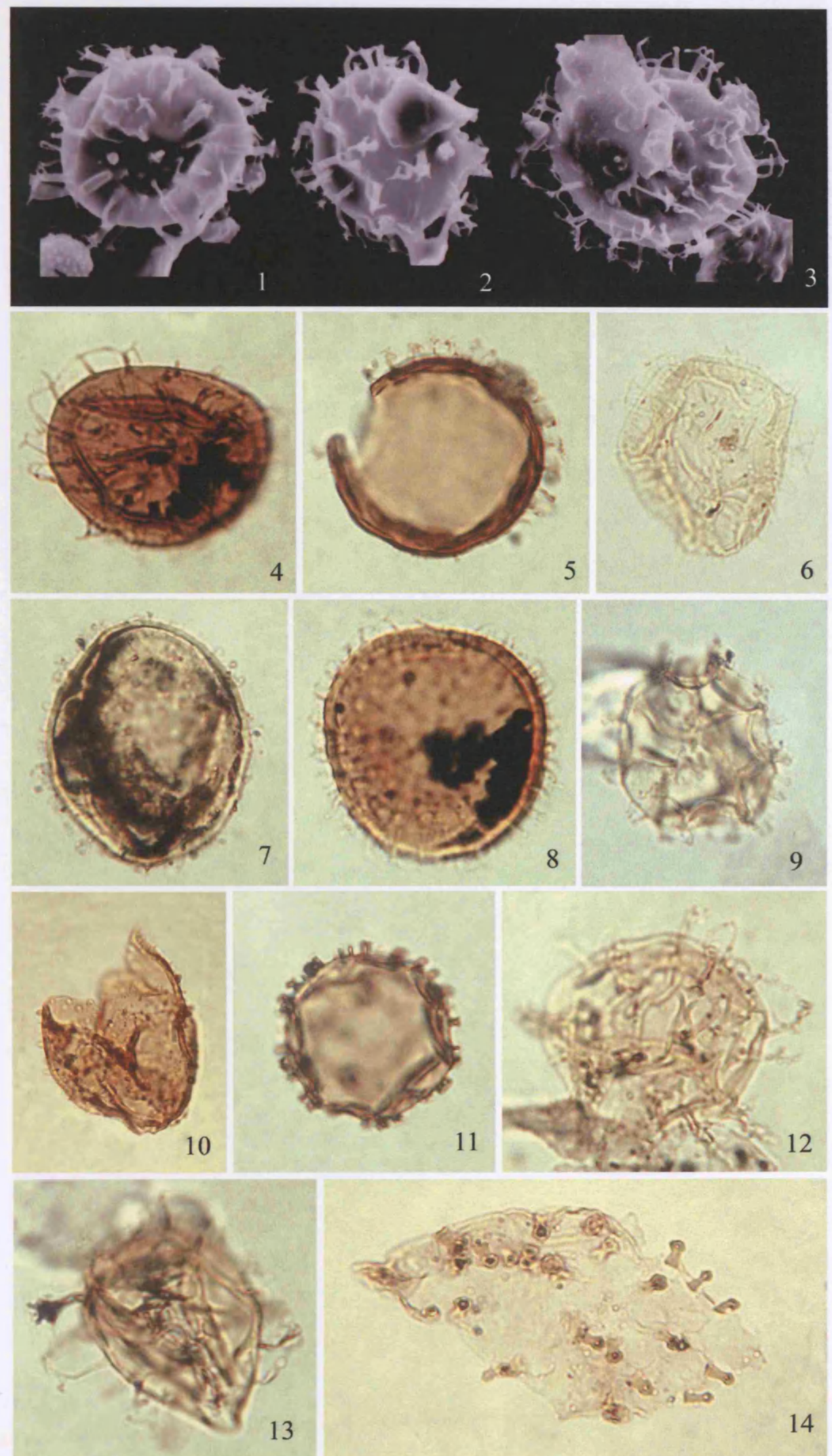
Fig.

Visbysphaera microspinosa (Eisenack, 1954) Lister, 1970

1 DG00LK1.28npg1-P34, Lower Visby Beds, x 750.

2 DG00LK1.40npg1-L38, 3, Lower Visby Beds, x 750.

Visbysphaera oligofurcata Eisenack, 1954

3 DG00LK1.72npg1-S38, Lower Visby Beds, $x 750$.

4 DG00LH2.9npg1-X32, Lower Visby Beds, $x 750$.

Visbysphaera pirifera pirifera (Eisenack, 1954) Kiryanov, 1978

5 DG00LK1.120-L4, (SEM), Lower Visby Beds, x 750.

6 DG00LK1.211npg1-R43, 1, Upper Visby Beds, x 750.

7 DG00LK1.112npg1-H33, Lower Visby Beds, $x 750$.

Visbysphaera pirifera minor Le Hérissé, 1989

8 DG00LK1.112npg1-F38, Lower Visby Beds, x 750.

9 DG00LK1.88npg1-U40, 1, Lower Visby Beds, x 750. 
PLATE 18
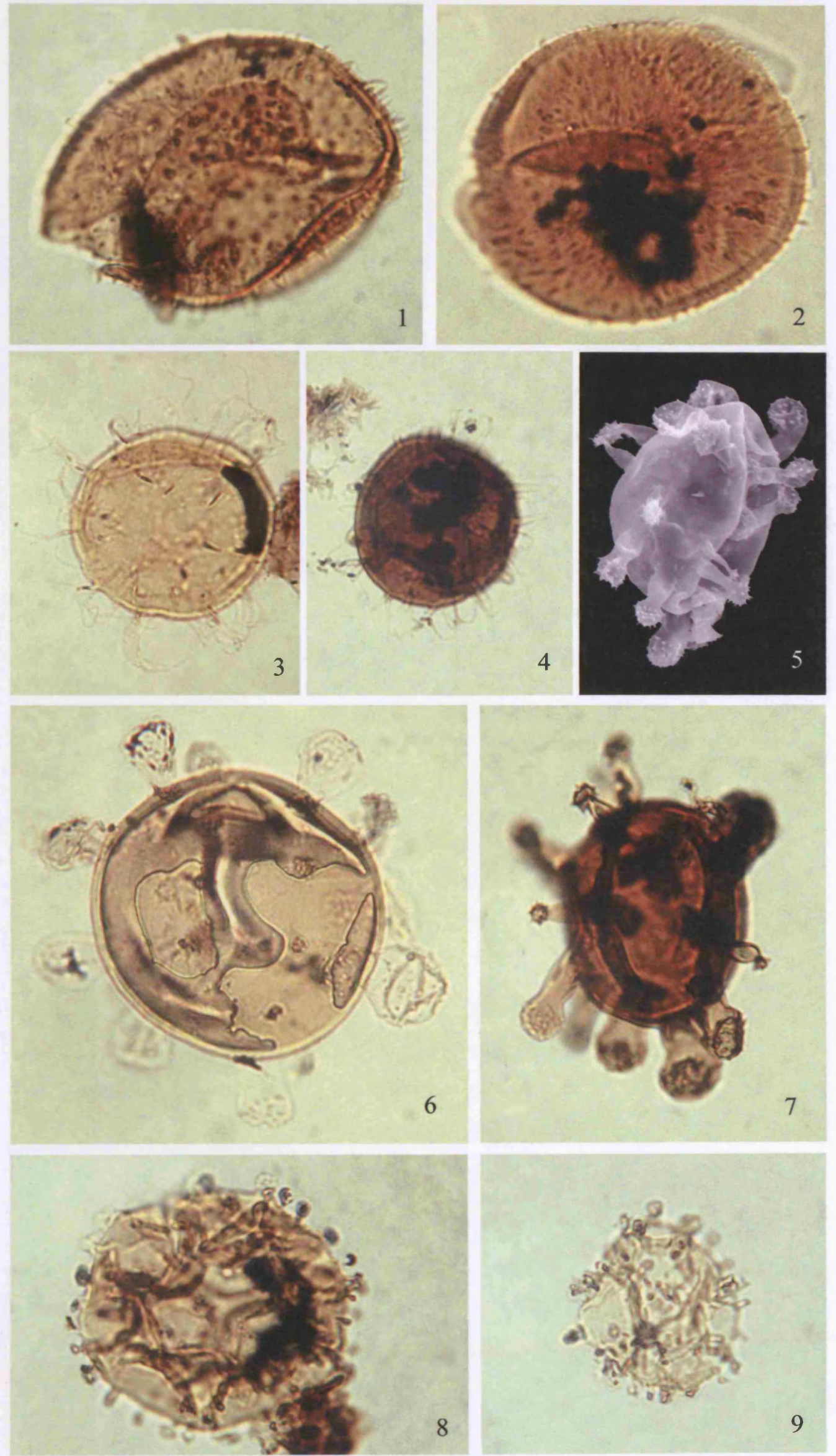
Fig.

1 DG00LK1.227npg1-U42, Upper Visby Beds, x 750. Holotype. Specimen photographed under differential interference contrast.

2 DG00LK1.223npg1-R40, Upper Visby Beds, $x$ 750. Specimen photographed under differential interference contrast.

3 DG00LK1.179npg1-D15, (SEM), Upper Visby Beds, $x 750$.

Specimen showing the inside of the vesicle where one of the processes has been broken off.

Micrhystridium sp. A

4 DG00LH2.17npg1-J32, 1, Upper Visby Beds, $x$ 750. Specimen shows lateral split (on the left). Specimen photographed under differential interference contrast.

5 DG00LK1.112npg1-O36, Upper Visby Beds, $x$ 750. Specimen photographed under differential interference contrast.

Elektoriskos longispinosum sp. nov.

6 DG00LK1.171npg1-O42, Upper Visby Beds, x 1000. Holotype.

$7 \quad$ DG00LK1.167npg1-M43, 3, Lower Visby Beds, x 750.

Pterospermella saturniforme sp. nov.

8 DG00LK1.56npg1-N34, 4, Lower Visby Beds, x 750. Holotype.*

9 DG00LK1.40npg1-M36, 4, Lower Visby Beds, $x 750$.

Buedingiisphaeridium? globulosum sp. nov.

10 DG00LK1.183npg1-R38, Upper Visby Beds, $x 750$.

11 DG00LK1.72npg1-J48, 3, Lower Visby Beds, x 750. Holotype.

Buedingiisphaeridium? aff. globulosum sp. nov.

12 DG00LK1.24npg1-H43, 1, Lower Visby Beds, x 750.

Abnormal acritarchs, probably mutations of Multiplicisphaeridium cladum (Downie, 1963) Eisenack, 1969.

13 DG00LK1.12npg1-N42, 3, Lower Visby Beds, $x$ 750. Specimen showing multiple primary branching on the right most process.

14 DG00LK1.155npg1-S43, 2, Upper Visby Beds, $x$ 750. Specimen showing very thick-walled, robust processes, with first order branching. 
PLATE 19
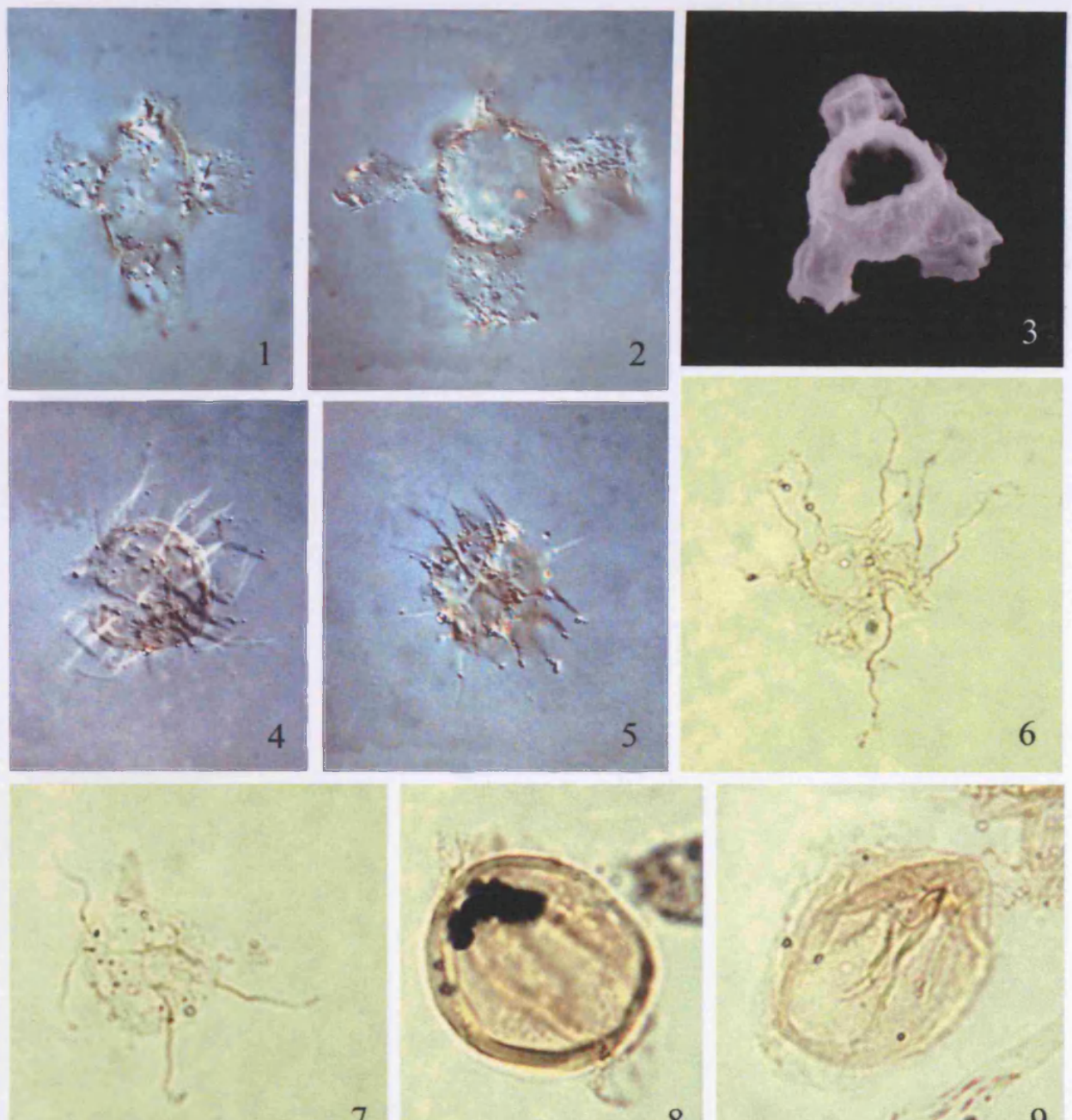

7
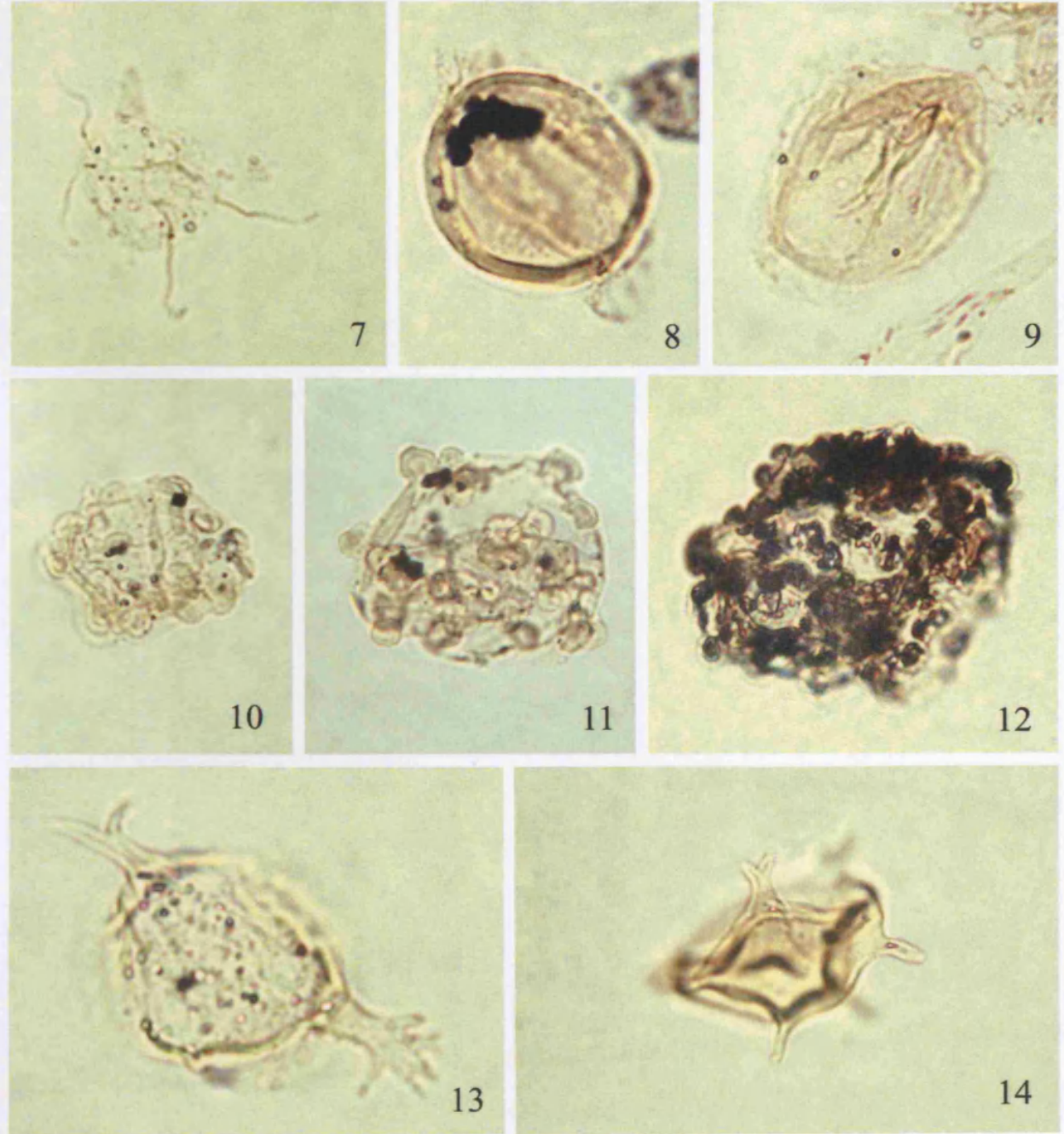